


\section{DISCLAIMER}

"This book was prepared as an account of work sponsored by an agency of the United States Government. Neither the United States Government nor any agency thereof, nor any of their employees, makes any warranty, express or implied, or assumes any legal liability or responsibility for the accuracy, completeness, or usefulness of any information, apparatus, product, or process disclosed, or represents that its use would not infringe privately owned rights. Reference herein to any specific commercial product, process, or service by trade name, trademark, manufacturer, or otherwise, does not necessarily constitute or imply its endorsement, recommendation, or favoring by the United States Government or any agency thereof. The views and opinions of authors expressed herein do not necessarily state or reflect those of the United States Government or any agency thereof."

Available from the National Technical Information Service, U.S. Department of Commerce, Springfield, Virginia 22161.

NTIS price codes

Paper copy:

Microfiche copy: $\$ 3.50$ 


\section{DISCLAIMER}

This report was prepared as an account of work sponsored by an agency of the United States Government. Neither the United States Government nor any agency Thereof, nor any of their employees, makes any warranty, express or implied, or assumes any legal liability or responsibility for the accuracy, completeness, or usefulness of any information, apparatus, product, or process disclosed, or represents that its use would not infringe privately owned rights. Reference herein to any specific commercial product, process, or service by trade name, trademark, manufacturer, or otherwise does not necessarily constitute or imply its endorsement, recommendation, or favoring by the United States Government or any agency thereof. The views and opinions of authors expressed herein do not necessarily state or reflect those of the United States Government or any agency thereof. 


\section{DISCLAIMER}

Portions of this document may be illegible in electronic image products. Images are produced from the best available original document. 


\title{
ENHANCED OIL RECOVERY BY IMPROVED WATERFLOODING
}

\author{
Second Annual Report
}

David M. Boghossian, Project Manager

Contributors:

Myron Allen

Trevor Castor

Terry Scriven

Energy Resources Co., Inc. 185 Alewife Brook Parkway Cambridge, Massachusetts 02138 $617 / 661-3111$

Fred W. Burtch, Technical Project Officer Bartlesville Energy Technology Center U.S. Department of Energy P.O. Box 1398

Bartlesville, Oklahoma 74003

918/336-2400, Extension 208

Prepared for the Department of Energy Under Contract No. DE-AC01-78ET 12065

Date Submitted-January 1980

Date Published-August 1980

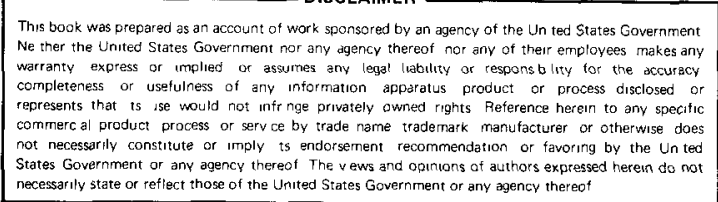


POLYMER IMPROVED WATERFLOOD

STORMS POOL UNIT, WHITE CO., ILLINOIS

Abstract

Energy Resources Co. Inc. is currently operating a pilot polymer improved waterflood of the Storms Pool, a sandstone reservoir in the Illinois basin. During the second year of the project, progress was made in all phases of the project most significantly in the laboratory work, field preparation, and computer simulation. In addition, Tasks II, VII, and IX, polymer selection, workovers, and model building were completed during 1979.

The polymer selected, based on laboratory comparisons of ten different products under simulated reservoir conditions, is a xanthan type polysaccharide polymer manufactured by Pfizer Inc. Other laboratory work included preliminary testing of biocides and oxygen scavengers. Development of the pilot area continued with the completion of the well workovers and the design and initiation of construction of the injection facility.

Preliminary simulation was begun to determine the effect of polymer adsorption, fieldwide drift, and other conditions on eventual production. An injection strategy will be determined based on these results.

In support of the laboratory and field operations, discussions were opened with Pfizer concerning a polymer purchase agreement and minimum quality standards were established. A complete environmental assessment of the project was made and proper containment and disposal facilities were added to the design of the injection system. 
TABLE OF CONTENTS

$\underline{\text { Page }}$

SECTION ONE INTRODUCTION AND SUMMARY

SECTION TWO RESERVOIR AND WELL TESTS

2.1 Reservoir Characteristics 7

2.2 Static Pressure Measurements 9

2.3 Interference Test Program 25

SECTION THREE POLYMER SELECTION AND SLUG DESIGN

3.1 Compatibility with River and Formation 29 Waters

3.1.1 Electrochemical Degradation 32

3.1.2 Mechanical Degradation 32

3.1.3 Viscosity in the Presence of 39 Biocides

3.2 Rheologic and Retentive Behavior in Cores 39

3.2.1 Core Flooding Methodology 43

3.2.2 Results of Core Flooding Experiments 46

3.2.3 Further Testing of Pfizer's 57

3.3 Filterability 71

3.4 Conclusions of the Polymer Selection Program 73

3.5 Slug Design 92

\section{SECTION FOUR LABORATORY TESTING AND EVALUATION}

4.1 Relative Permeabilities 97

4.2 Capillary Pressure 105

4.3 Microbiology of the Storms Pool 105

4.3.1 Materials and Methods 105

4.3 .2 Results 110

4.3.3 Discussion 111

4.4 Quality Control Program 114 
TABLE OF CONTENTS (CONT.)

$\underline{\text { Page }}$

$\begin{array}{ll}\text { SECTION FIVE WELL PREPARATION } & 117\end{array}$

5.I The New Well 10-5 117

5.2 Injection Well Workovers 117

5.3 Production Wells 122

$\begin{array}{lll}\text { SECTION SIX } & \text { CONSTRUCTION OF FACILITIES } & 125\end{array}$

6.1 Preparation of the Pilot Site 125

6.2 Plant Design and Purchasing of Equipment 125

6.3 Fabrication of the Injection Plant 130

6.4 Current Status 131

SECTION SEVEN RESERVOIR SIMULATION 133

7.1 Simulation Strategy 133

7.2 Preliminary Simulator Runs 133.

$\begin{array}{lll}\text { SECTION EIGHT } & \text { PROGRAM SUPPORT } & 145\end{array}$

8.1 Purchase of Polymer 145

8.2 Environmental Assessment and 146

APPENDIX $\quad$ LIST OF INSTRUMENTATION AND EQUIPMENT FOR PILOT INJECTION FACILITIES 


\begin{tabular}{|c|c|c|}
\hline SECTION & ONE & INTRODUCTION AND SUMMARY \\
\hline SECTION & TWO & RESERVOIR AND WELL TESTS \\
\hline 1 & & $\begin{array}{l}\text { Amerada Bottom-Hole Pressure } \\
\text { Measurements for Well } 6-4\end{array}$ \\
\hline 2 & & $\begin{array}{l}\text { Amerada Bottom-Hole Pressure } \\
\text { Measurements for Well } 9-2\end{array}$ \\
\hline 3 & & $\begin{array}{l}\text { Amerada Bottom-Hole Pressure } \\
\text { Measurements for Well } 9-3\end{array}$ \\
\hline 4 & & $\begin{array}{l}\text { Amerada Bottom-Hole Pressure } \\
\text { Measurements for Well 10-1 }\end{array}$ \\
\hline 5 & & $\begin{array}{l}\text { Amerada Bottom-Hole Pressure } \\
\text { Measurements for Well } 10-3\end{array}$ \\
\hline 6 & & $\begin{array}{l}\text { Amerada Bottom-Hole Pressure } \\
\text { Measurements for Well } 12-4\end{array}$ \\
\hline 7 & & $\begin{array}{l}\text { Results of Static Pressure } \\
\text { Measurements }\end{array}$ \\
\hline SECTION & THREE & POLYMER SELECTION AND SLUG DESIGN \\
\hline 8 & & $\begin{array}{l}\text { Identification of Polymers by } \\
\text { Manufacturers, Product Type, state } \\
\text { and Weight Percent }\end{array}$ \\
\hline 9 & & $\begin{array}{l}\text { Composition of Formation and River } \\
\text { Water in Storms Pool Project }\end{array}$ \\
\hline 10 & & $\begin{array}{l}\text { Electrochemical Degradation of } 500 \mathrm{ppm} \\
\text { Active Polymer at a Shear Rate of } \\
7.3{\text { sec-1 and } 95^{\circ} \mathrm{F}}^{-1}\end{array}$ \\
\hline 11 & & $\begin{array}{l}\text { Viscoelastic Response of Polymers } \\
\text { as Measured by Screen Factor }\end{array}$ \\
\hline 12 & & $\begin{array}{l}\text { Rheological Behavior of Polymers } \\
\text { in Reservoir Cores at } 95^{\circ} \mathrm{F} \text { and } \\
22.0^{\prime} / \mathrm{day}\end{array}$ \\
\hline 13 & & $\begin{array}{l}\text { Retentive Behavior of Polymers in } \\
\text { Reservoir Cores at } 95^{\circ} \mathrm{F} \text { and } 2.0^{\prime} / \\
\text { day with an } 80 / 20 \mathrm{Mix} \text { of River and } \\
\text { Formation Water }\end{array}$ \\
\hline
\end{tabular}




\begin{tabular}{|c|c|c|}
\hline SECTION & THREE & (CONT.) \\
\hline 14 & & $\begin{array}{l}\text { Electrochemical Degradation of } 500 \mathrm{ppm} \\
\text { Active Polymer at a Shear Rate of } \\
7.3{\text { sec-1 and } 95^{\circ} \mathrm{F}}^{-1}\end{array}$ \\
\hline 15 & & $\begin{array}{l}\text { Rheological and Retentive Behavior of } \\
\text { a Polysaccharide and a Polyacrylamide } \\
\text { in Reservoir Core at } 95^{\circ} \mathrm{F} \text { and } \\
\sim 2.0 \text { 'ft/day. }\end{array}$ \\
\hline 16 & & $\begin{array}{l}\text { Retention Rates of Phizer's Floccon } \\
\text { l035 Using Filtered and Unfiltered } \\
\text { Makeup Water }\end{array}$ \\
\hline 17 & & $\begin{array}{l}\text { Polysaccharide G Millipore Filter } \\
\text { Ratios of } 500 \text { ppm Active Polysaccharide } \\
\text { Product under a Pressure of } 40 \text { psi }\end{array}$ \\
\hline 18 & & $\begin{array}{l}\text { Millipore Filter Ratios Measured by } \\
\text { Energy Resources for Candidate } \\
\text { Polysaccharides }\end{array}$ \\
\hline 19 & & $\begin{array}{l}\text { Costs of Polymers per Active Pound, } \\
\text { mid- } 1979\end{array}$ \\
\hline 20 & & $\begin{array}{l}\text { Summary of Characteristics of Pfizer's } \\
\text { Flocon } 1935 \text { (Polysaccharide GI) }\end{array}$ \\
\hline 21 & & $\begin{array}{l}\text { Calculation of Graded Polymer Slug } \\
\text { Stages for Viscous Buffer }\end{array}$ \\
\hline 22 & & $\begin{array}{l}\text { Polymer Requirements for Each Stage } \\
\text { in a Quarter Five-Spot }\end{array}$ \\
\hline SECTION & FOUR & LABORATORY TESTING AND EVALUATION \\
\hline 23 & & $\begin{array}{l}\text { Relative Permeability Measurements on } \\
\text { Rudolph 5, Leve1 } 2293^{\prime} \text {, as Measured } \\
\text { by Elf-Aquitaine, August } 1979\end{array}$ \\
\hline 24 & & $\begin{array}{l}\text { Comparison of Endpoint Saturations and } \\
\text { Relative Permeabilities as Measured } \\
\text { by Energy Resources and Elf-Aquitaine }\end{array}$ \\
\hline 25 & & $\begin{array}{l}\text { Colony-Forming Units of Bacteria in } \\
\text { Formation water, River } \mathrm{H}_{2} \mathrm{O} \text { and } \\
\text { Sediment }\end{array}$ \\
\hline
\end{tabular}


SECTION FOUR

26

27

28
(CONT.)

Storms Pool Unit Bacterial Taxonomy: Predominance and Distribution of Bacterial Taxa from Sampled River and Formation Waters

Nutritional Capabilities: Growth of Colonies in Biopolymer G2, Copolymer and Model Hydrocarbon Mixture

Quality Control Parameters for Polysaccharide
112

113

115

136

Preliminary Simulator Runs

Injection and Production Rates 
SECTION ONE

1

2

\begin{tabular}{c} 
SECTION TWO \\
\hline 3 \\
4 \\
5 \\
6 \\
7 \\
8 \\
9
\end{tabular}

11

SECTION THREE

11

12

13

14
INTRODUCTION AND SUMMARY

Location of the Storms Pool pilot polymer flood.

The Storms Pool and location of the pilot area.

\section{RESERVOIR AND WELL TESTS}

Profile of Well 6-4, October 19, 1979. 10

Profile of Well 9-2, October 18, 1979. 11

Profile of Well 9-3, October 17, 1979. 12

Profile of Well 10-1, October 18, 1979. 13

Profile of Well 10-3, October 19, 1979. 14

Profile of Wel1 12-4, October 17, 1979. 15

Geometry of proposed interference 27

tests.

Estimates pressure change, as a function of distance and time, for proposed interference tests.

\section{POLYMER SELECTION AND SLUG DESIGN}

Viscosity as a function of polymer concentration in $100 \%$ river water and in $80 / 20 \mathrm{mix}$ of river and formation waters

Viscosity as a function of concentration for biopolymer $\mathrm{J}$ at $95^{\circ} \mathrm{F}$ and 7.3 sec $^{-1}$ with salt concentration as a parameter

Viscosity at $500 \mathrm{ppm}$ as a function of shear with river water and with $80 / 20$ $\mathrm{mix}$ of river and formation waters

$V$ iscosity as a function of shear for biopolymer $J$ at $95^{\circ} \mathrm{F}$ and 500 and $1,000 \mathrm{ppm}$ of active polymer concentration with salt concentration as a parameter 


\section{SECTION THREE (CONT.)}

function of rpm for polysaccharide Gl with formaldehyde

Percent change in viscosity as a

function of rpm for polysaccharide Gl with acrolein

Percent change in viscosity as a

function of rpm for polysaccharide Gl with Visco 3991

Resistance factor and concentrations of Polymer $\mathrm{E}$ in reservoir cores at $95^{\prime} \mathrm{F}$.

Resistance factor and concentrations of Polymer E2 in reservoir cores at $95^{\prime} \mathrm{F}$.

20 Resistance factor and concentrations of Polymer $B$ in reservoir cores at $95^{\prime} \mathrm{F}$.

21 Resistance factor and concentrations of Polymer $\mathrm{G} 2$ in reservoir cores at $95^{\prime} \mathrm{F}$.

Resistance factor of polymer E2 in reservoir cores at $95^{\circ} \mathrm{F}$

Resistance factor of polymer E2 in reservoir cores at $95^{\circ} \mathrm{F}$

Resistance factor of polymer El with aluminum citrate in reservoir cores at $95^{\circ} \mathrm{F}$

Resistance factor and concentration profile of polymer $\mathrm{C} 2$ in $80 / 20 \mathrm{mix}$ with thiocyanate reservoir cores at $95^{\circ} \mathrm{F}$ the connate water and in the injected solution 
SECTION THREE (CONT.)

Resistance factor and concentrations

of Polymer $\mathrm{E} 2$ in reservoir core at

$95^{\circ} \mathrm{F}$ with 1008 formation brine in

the connate water and in the injected solution

Breakthrough concentration profile of dilute polysaccharide solution from reservoir cores (Waltersburg Formation) at $75 \pm 2^{\circ} \mathrm{F}$

Resistance factor of dilute polysaccharide solution from reservoir cores (Waltersburg Formation) at $75 \pm 2^{\circ} \mathrm{F}$

31 Breakthrough concentration profile of dilute polysaccharide solution from reservoir cores (Waltersburg Formation) at $75+2^{\circ} \mathrm{F}$

32 Resistance factor of dilute polysaccharide solution from reservoir cores (Waltersburg Formation) at $75 \pm 2^{\circ} \mathrm{F}$

Breakthrough concentration profile of dilute polysaccharide solution from reservoir cores (Waltersburg Formation) at $75+2^{\circ} \mathrm{F}$

Resistance factor of dilute polysaccharide solution in reservoir cores (Waltersburg Formation) at $75 \pm 2^{\circ} \mathrm{F}$

Breakthrough concentration profile cores (Waltersburg Formation) at $75 \pm 2^{\circ} \mathrm{F}$

Resistance factor of dilute polysaccharide solution from reservoir cores at $75+2^{\circ} \mathrm{F}$

Calibration curve for polysaccharide concentration by the phenol/ $\mathrm{H}_{2} \mathrm{SO}_{4}$ method assay

Results of Core Laboratories' millipore filter tests for polysaccharide GI at $1000 \mathrm{ppm}$ in pure river water 
Page

\section{SECTION THREE (CONT.)}

39

40

41

42

43

44

46

47

48

49

50

51
Results of Core Laboratories' millipore filter tests for polysaccharide Gl at 500 ppm in pure river water

Results of Core Laboratories' millipore filter tests for polysaccharide Gl at $1000 \mathrm{ppm}$ in an $80 / 20 \mathrm{mix}$ of river and formation waters

Results of Core Laboratories' millipore filter tests for polysaccharide Gl at $500 \mathrm{ppm}$ in an $80 / 20 \mathrm{mix}$ of river and formation waters

Results of Core Laboratories' millipore filter tests for polysaccharide $\mathrm{H}$ at $500 \mathrm{ppm}$ in pure river water

Results of Core Laboratories' millipore filter tests for polysaccharide $\mathrm{H}$ at $500 \mathrm{ppm}$ in an $80 / 20 \mathrm{mix}$ of river and formation waters

Filterability of dilute polysaccharide solutions ( 500 ppm active polymer) of xanthan gum broths

Filtration time curves for polysaccharide GI

Filtration time curves for polysaccharide Gl with formaldehyde

Filtration time curves for polysaccharide GI with acrolein

Filtration time curves for polysaccharide G1 with Visco 3991

Filtration time curves for polysaccharide G1

Filtration time curves for polysaccharide Gl with acrolein

Filtration time curves for polysaccharide GI with formaldehyde
76 77 78

75

79

80

81

84

85

86

87 
SECTION THREE (CONT.)

52 Filtration time curves for polysaccharide G1 with Visco 3991

SECTION FOUR

54

55

56

57

58

59

60

\section{SECTION FIVE}

61

62

63

64

Schematic of polymer slug stages

Relative Permeabilities vs. Water Saturation

Relative Permeability Ratio vs. Saturation

Fractional flow of water vs. brine saturation at well 10-5, as measured by Elf-Aquitaine

Relative permeability vs. water saturation

Comparison of total relative mobility versus saturation for curves measured by Energy Resources and Elf Aquitaine

Capillary Pressure vs. Saturation

$\begin{array}{lll}\text { Layout of Storms Pool pilot facilities } & 118 \\ \text { Gamma Ray Neutron Log, well } 10-5 & 119\end{array}$

Dual Induction Laterolog, Well 10-1

121

Profiles of storms Pool pilot injection wells

\section{SECTION SIX}

65

66

67
CONSTRUCTION OF FACILITIES

\section{Layout of Storms pool pilot road} network

Injection plant layout

128

Piping and Instrumentation Diagram 


\section{LIST OF FIGURES (CONT.)}

$\underline{\text { Page }}$

SECTION SEVEN

68

69

70

71

\section{SECTION SEVEN}

71

72

73

74
RESERVOIR SIMULATION

Boundaries assumed in three pre-

134 Iiminary simulation cases

Streamtubes generated by polymer flood simulator for Cases I and I' (no drift)

Streamtubes generated by polymer flood simulator for Case II (drift from southwest to northeast)

Simulator performance predictions for Case I (no drift, retention = $20 \mathrm{\mu g} / \mathrm{g}$ rock)

RESERVOIR SIMULATION

Simulator performance predictions for Case I (no drift, retention = $20 \mathrm{\mu g} / \mathrm{g}$ rock)

Simulator performance predictions for Case I' (no drift, retention= $30 \mathrm{~kg} / \mathrm{g}$ rock)

Simulator performance predictions for Case II (no drift, retention = $20 \mathrm{\mu g} / \mathrm{g}$ rock)

Comparison of simulator performance predictions for Cases I, I', and II

\section{SECTION EIGHT PROGRAM SUPPORT}


SECTION ONE

INTRODUCTIION AND SUMMARY

Energy Resources Co. Inc. and its subcontractor Elf-Aquitaine $O i l$ and Gas Company are conducting a pilot polymer flood in the Storms Pool near Carmi, in white County, Illinois (see Figure 1). The project is a costsharing venture in which Energy Resources and the United States Department of Energy (DOE) bear equal shares in the expenditure of $\$ 2,170,955$ for equipment, chemicals, and labor. Preparation for the polymer flood began in september 1977, under DOE Contract Number DE-ACO1-78ETI2065, and the project is scheduled for completion in December 1982. This report reviews progress during the second year of performance. Progress during the first year is reported in DOE document BETC/2541-12, "Enhanced Oil Recovery by Improved waterflooding: First Annual Report."

The Storms Pool is typical of many old fields in the Illinois Basin which are candidates for enhanced oil recovery. Once highly productive, the field has yielded over 12 million barrels of oil from the waltersburg formation since its discovery in 1939. The field has been waterflooded for over 20 years and is now largely in stripper production with high watercuts at nost producing wells. Material balance and recent electric logs indlcate, however, that there is a substantial volume of movable oil still in place, presumably bypassed by the ir əfficent waterflood. The polymer flood is intended to imr cove the sweep efficiency, showing that the engineering, management, and financial resources required for such tertiary techniques can be applied to similar fields that might otherwise be abandoned for lack of investment by large oil companies or other outside parties knowledgeable in enhanced oil recovery technology.

The first annual report reviewed the groundwork upon which much of the second year's work was based. That report included a geologic analysis of the storms pool and its production potential, the rationale for the selection of a pilot site (shown in Figure 2), some preparation of wells and facilities, an extensive plan for testing candidate polymers in the laboratory, and a proposed approach to computerized simulation of the pilot polymer flood. The present report reviews a year of intensive laboratory, design and field work, including a reservoir and well test program, the results of the polymer selection and additional laboratory testing, workovers and construction of facilities, preliminary reservoir simulation, and program support activities. 


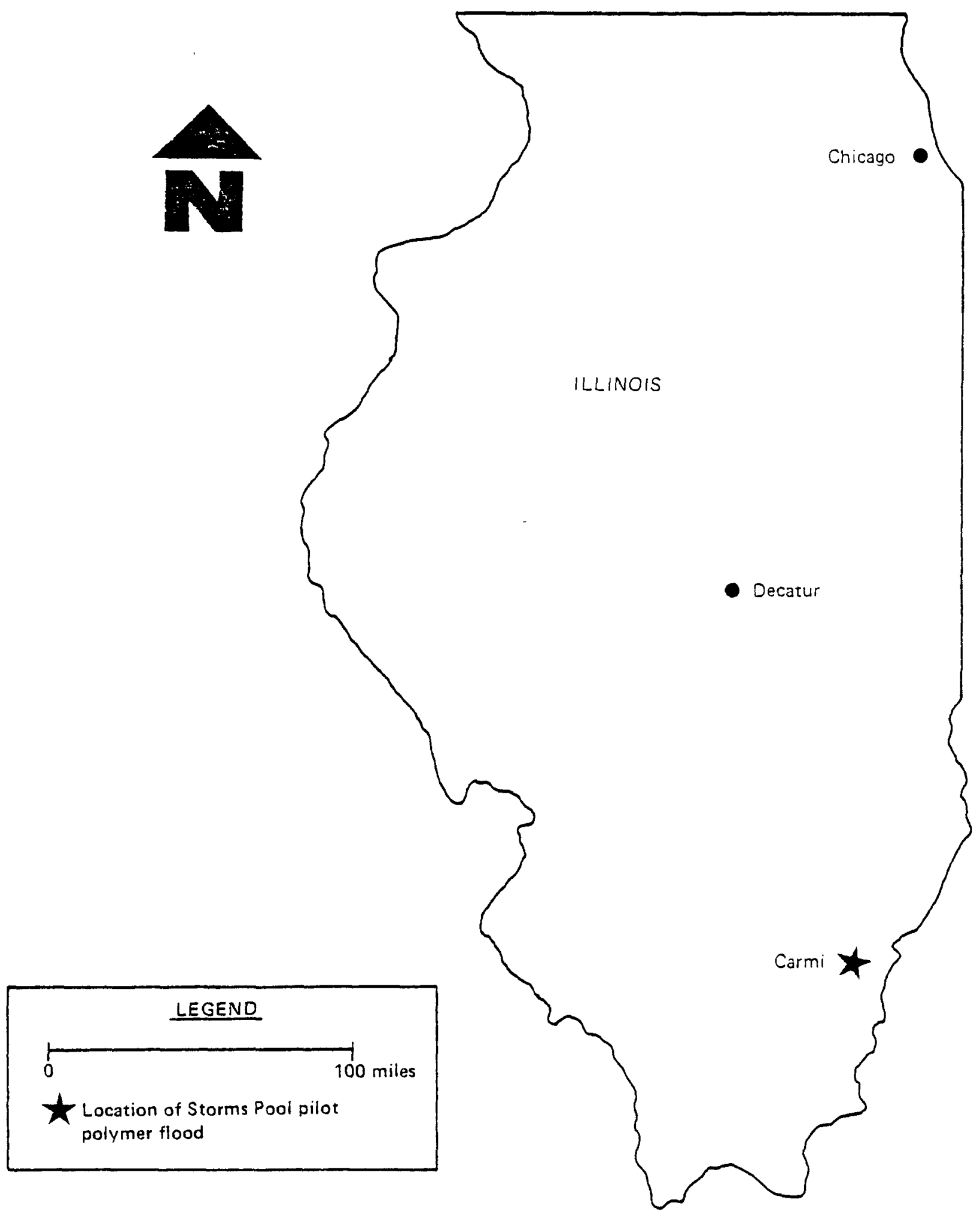

Figure 1. Location of the Storms Pool pilot polymer flood. 

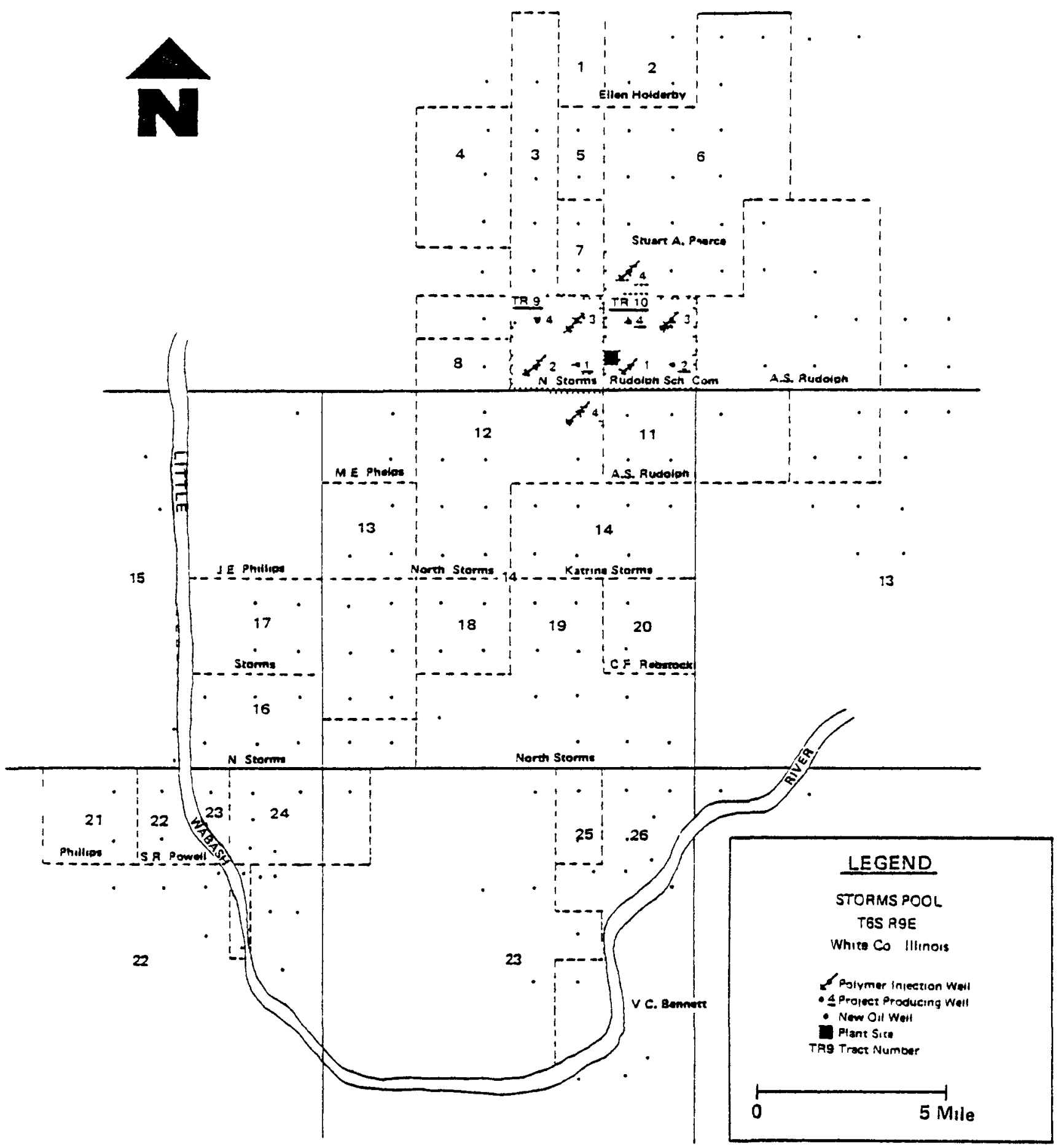

Figure 2. The Storms Pool and location of the pilot area. 
The reservoir analysis presented in the first annual report gives evidence that, although oil saturations higher than 40 percent exist in the pilot area, the fluid saturations and rock properties are vertically nonuniform in the 50-foot pay zone. Since the waterflood is also characterized by an adverse mobility ratio, it is reasonable to expect that viscous fingering and water channeling have contributed to the high watercuts experienced in the past decade. Although an uneven field-wide distribution of injectors and producers led to concern over a possible fluid drift across the pilot area, static pressure measurements revealed no pressure gradient strong enough to cause such a drift. A set of transient pressure tests has been designed to help determine the degree of fluid movement between the wells in the pilot area.

Twelve polymers, including eight polyacrylamides and four polysaccharides, were chosen as candidates to be tested in the laboratory. Experiments conducted by Energy Resources, Core Laboratories of Dallas, Texas, and several polymer vendors yielded data on the compatibility of polymers with makeup water and formation brine, rheologic and retentive behavior of polymer solutions in reservoir cores, and filterability of polymer solutions. Consideration of these results along with costs and logistics led to the selection of Pfizer Chemicals Division's polysaccharide, Flocon 1035. This polymer showed a low susceptibility to aegradation by saline formation brine and to permanent viscosity reduction by the high shear rates expected to prevail at injection wellbores. The data from these laboratory studies supported the design of a graded polymer slug featuring buffers against retention ana viscous fingering at the upstream edge.

Further laboratory work by Energy Resources and Elf-Aquitaine yielded relative permeability and capillary pressure curves for use in reservoir engineering and simulation. These curves show that the Waltersburg sandstone in the pilot area is slightly water-wet and help explain the field's high watercuts. Energy Resources' microbiology laboratory conducted a taxonomic screen of the microbial population in the makeup and formation waters and performed a set of experiments to determine whether any species would be likely to attack the injected polymer. Based on these results, biocides have been chosen for injection with the polymer. A quality control program will help assure consistency of the chemicals delivered to the field.

Workovers at most of the 11 wells of the pilot area helped to correct several problems typically encountered 
in old fields. Most of the wells were acidized; the new producer Well $10-5$ was perforated, and new Gulberson pumps and rods were run in the old producers. One injector was squeezed at the gas cap and deepened to the bottom of the producing interval to give a better injection profile.

An injection plant now stands between Tracts 9 and 10. Injection lines are in place, and much of the equipment needed for polymer injection has been assembled.

Energy Resources and Elf-Aquitaine developed a plan for numerical simulation to support the design and monitoring of the polymer slug. The plan calls for three phases, including preliminary simulations using a stream-tube model to provide rough estimates of fluid flow patterns, polymer requirements, and fluid production; detailed simulation using refined laboratory and reservoir data to determine an injection strategy; and quarterly simulator runs to monitor field performance. Preliminary simulations revealed that fluid drift, if present, could cause an inefficient polymer flood and that polymer retention rates significantly higher than accepted laboratory rates could reduce oil recovery by up to 30 percent. Subsequent field and laboratory tests indicate that neither of these potential sources of inefficiency will be present.

Program support activities included the signing of a letter of intent to purchase polysaccharide from Pfizer and an environmental assessment of the polymer flood. The environmental assessment found that the project would have negligible impact on the local environment. An environmental protection plan will ensure the safe handling and disposal of fluids during the operation of the polymer flood. 
-

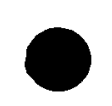

$-6-$ 
SECTION TWO

RESERVOIR AND WELL TESTS

During 1979 the project team used results of the reservoir analysis to design and interpret static pressure measurements. A plan was also outlined for pressure interference tests. This section discusses these activities.

\subsection{Reservoir Characteristics}

To guide the design and interpretation of pressure tests, the project team established several hypotheses concerning reservoir characteristics peculiar to the pilot area. These hypotheses are based on the reservoir description presented in the first annual report and on subsequent analysis of field data. Although the hypotheses do not provide a complete definition at the producing zone in the pilot area, they help explain discrepancies between the reservoir's performance and ideal waterflood behavior.

First, there appears to exist an interval of roughly 35 feet where movable oil resides in the pilot area. The oil saturations in this interval exceed 40 percent in places, although areal variations may exist. This hypothesis is based on conservative interpretation of the dual induction laterologs taken from Well 10-5, drilled in 1978. These logs show an average oil saturation of about 40 percent in the interval 1866 to 1900 feet subsea. Material balance calculations on the production in Tracts 9 and 10 estimate that 60 percent of the original oil in-place $(72$ percent saturation) has been produced, corroborating the logs at Well 10-5.

Second, the oil saturation is vertically nonuniform in the pilot area, being lower in the bottom 10 to 15 feet of pay and perhaps in sand originaliy in the gas cap that overlay portions of the pilot area. The fluid saturations in the Schlumberger Coriband analysis at Well 10-5 show less oil saturation in the lower zone (1876 to 1910 feet subsea), in agreement with electric logs taken early in the field's drilling history and a 1958 study for Sinclair oil Company. The existence of an extended lower zone of high water saturation (and therefore high water permeability) is consistent with the tendency, noted by early operators, of wells shot below 1890 feet subsea to produce at large watercuts. The excess in volume of fluids injected over volume produced during the waterflood suggest higher water saturations in the former gas cap. 
Third, the reservoir rock in the pilot area is vertically inhomogeneous, although the heterogeneities do not seem to be areally consistent. Core analyses show two kinds of vertical variations: one comprising thin, impermeable shale streaks that have no apparent correlation from well to well and the other being irregular fluctuations in ideal-gas permeability, again having no apparent areal significance.

These three hypotheses support a fourth; namely, that the flow of oil and water in the pilot area is characterized by water channeling and consequently by injected water bypassing oil. Water channeling is a plausible explanation for high watercuts at producers despite the existence of significant mobile oil saturations in parts of the field (e.g., at well 10-5). Also, channeling could have been promoted by vertical variations in rock and fluid properties as well as by viscous instabilities due to the unfavorable mobility ratio between injected water and oil. Injection profiles measured by Sinclair in 1958 led that company to conclude that injected water was entering the underlying zone of high water saturation. Selective plugging of injectors around well $12-1$ in 1958 (near the pilot area) back to around 1880 feet subsea resulted in improved oil recovery, supporting that conclusion. Channeling through the old gas cap may also have occurred. Well 9-1, for example, has 5 feet of gas sand and produced at the highest watercuts of Tracts 9 and 10 before being shut in; an adjacent injector, Well 12-4, was originally perforated in the gas cap. Throughout the history of the waterflood, oil cuts have been much higher at producers without a gas cap and completed above 1880 feet subsea. This project will attempt to control mobility in the gas cap and water zone by injecting polymer into them.

Fifth, the field-wide pattern of injection and production indicates the possibility of a large scale drift of fluids across the pilot area. Jim Haley production Company currently has more injectors than producers southwest and upstructure of the pilot area and more producers than injectors northeast and downstructure. A southwest-tonortheast fluid drift could be the result, and such a drift, if large enough in magnitude, could adversely affect the confinement of fluids in the pilot pattern.

Finally, there is some possibility that zones of gas sand exist which are not liquid saturated. If this is the case, then the compressibility of fluids near these zones will be large, a circumstance that could affect the interpretation of pressure pulse tests. 


\subsection{Static Pressure Measurements}

In October, 1979, we performed static pressure measurements in the pilot area. Static pressures at injectors were measured using Amerada bottom-hole pressure recorders, and at the same time echometer readings were taken at producers. These measurements yielded static pressures at each well in the pilot area.

The following procedure was used.

October 9 The two active producers, wells 10-2 and 10-4, were shut in to allow reservoir pressure to stabilize. A tubing-end locator was run in each injector to check the depths of tubing ends, fluid levels, and bottoms. These results are shown schematically in Figures 3 through 8 .

October 17 Otis Engineering Company of St. Elmo, Illinois, ran an Amerada bottom-hole pressure recorder in Wells $9-3$ and $12-4$.

October 18 Otis ran Amerada pressure recorders in Welis $9-2$ and 10-1.

October 19 Otis ran Amerada pressure recorders in Welis $6-4$ and 10-3.

The results of the injector surveys are shown in Tables 1 through 6. The readings in Table 1 show that the pressure in Well 6-4 had not stabilized at the time of the survey but was still falling; therefore the results for this well are not reliable.

The static pressure measurements for the six injectors and five producers are summarized in Table 7. The rightmost column lists the static pressures corrected to a datum depth of 1831 feet subsea. Two static pressure estimates are given for producers, one based on the assumption that the annulus is filled with water, the other assuming an oilfilled annulus. The assumption of a water-filled annulus is probably accurate for producers 9-1, 9-4, 10-2, and 10-4, which had recently been acidized. The presumed higher oil saturation and the high liquid level at the new Well 10-5 suggest that its annulus may be partially oil-filled.

Discounting the measurement at 6-4, there appears to be a net pressure difference of approximately 35 psig between the southwest and northeast ends of the pilot area. Since the distance between, say, Wells 12-4 (southwest edge) and 10-3 (northeast edge) is 1866 feet, the overall pressure 


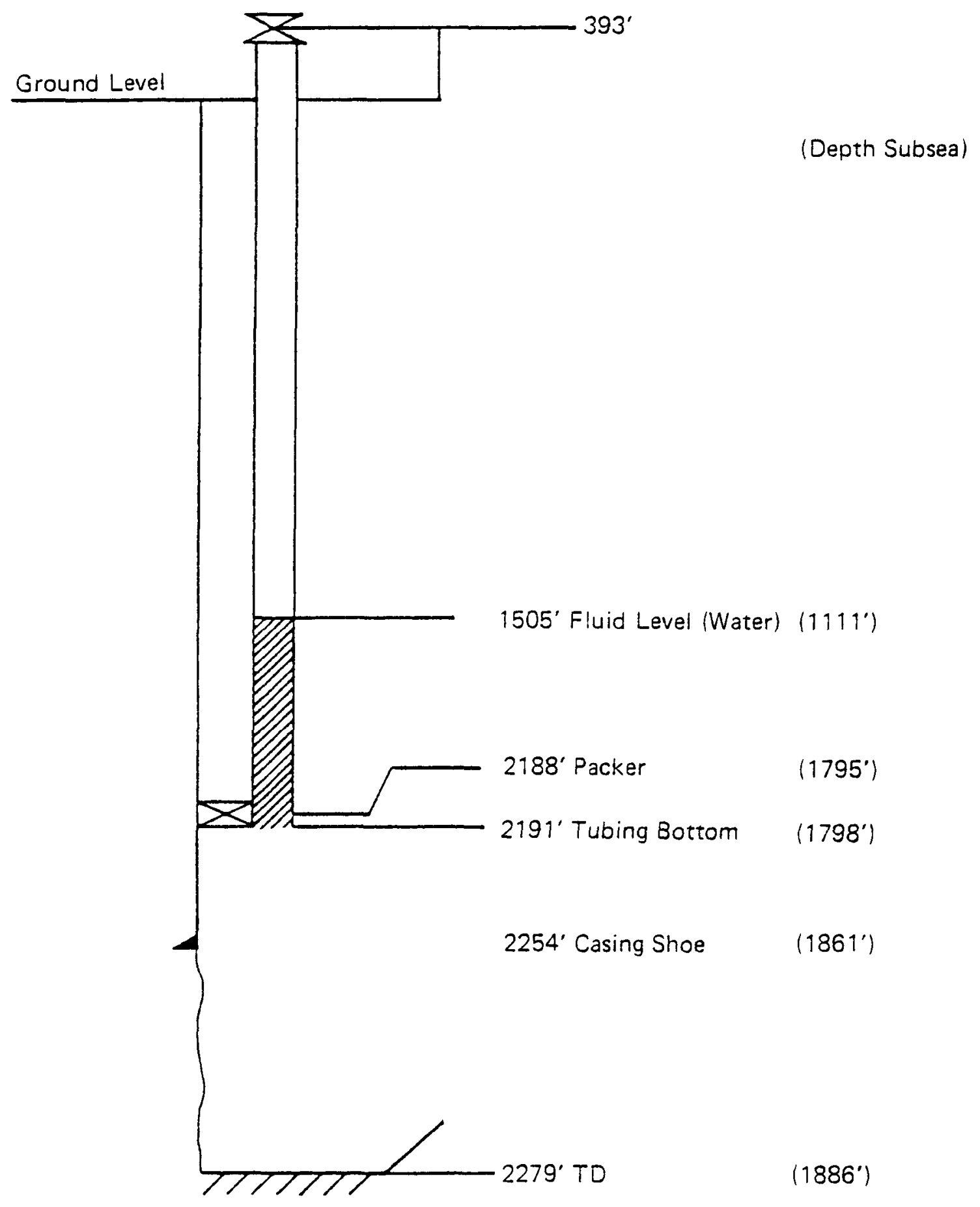

Figure 3. Profile of Well 6-4, October 19, 1979. 


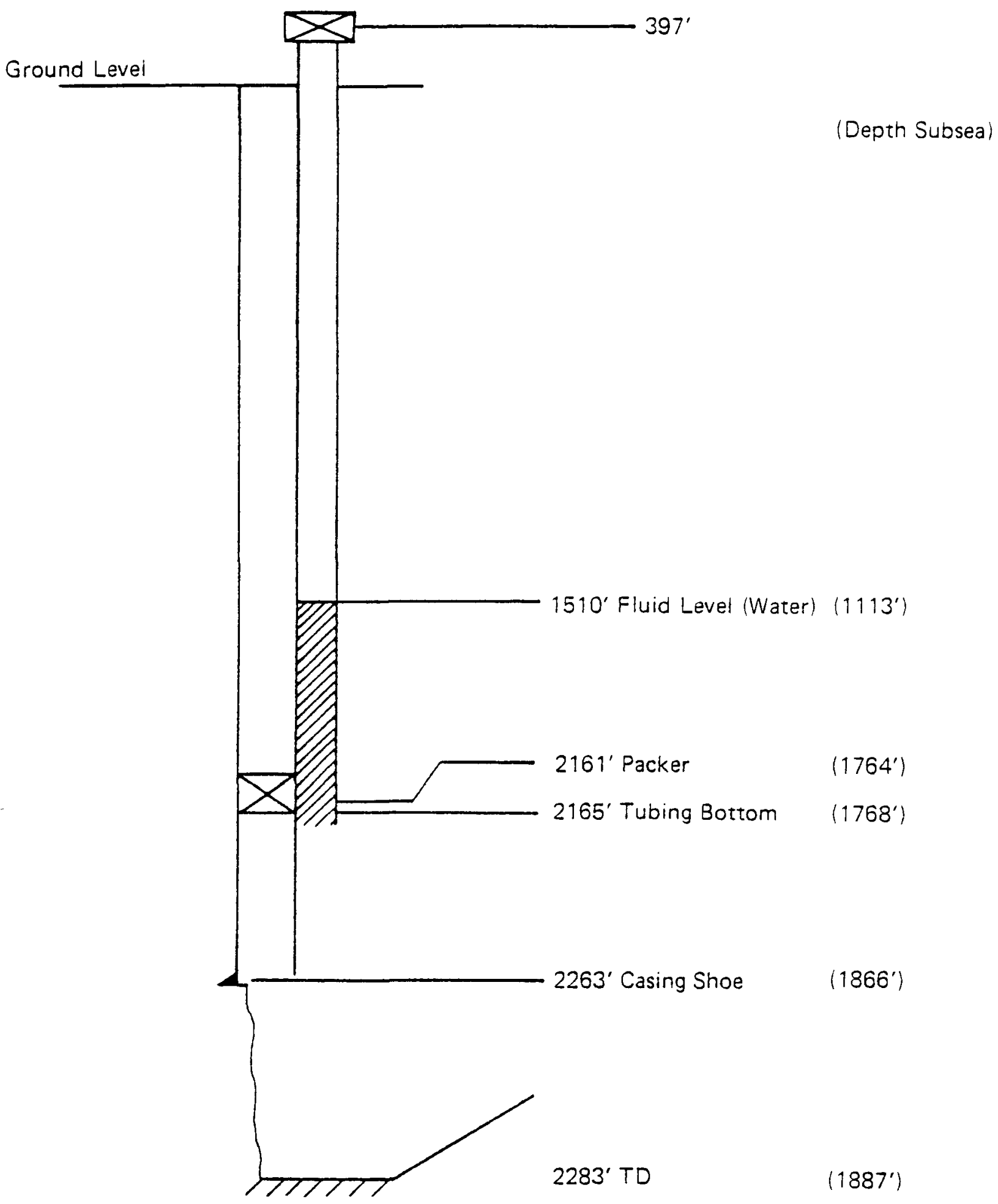

Figure 4. Profile of Well 9-2, October 18, 1979. 


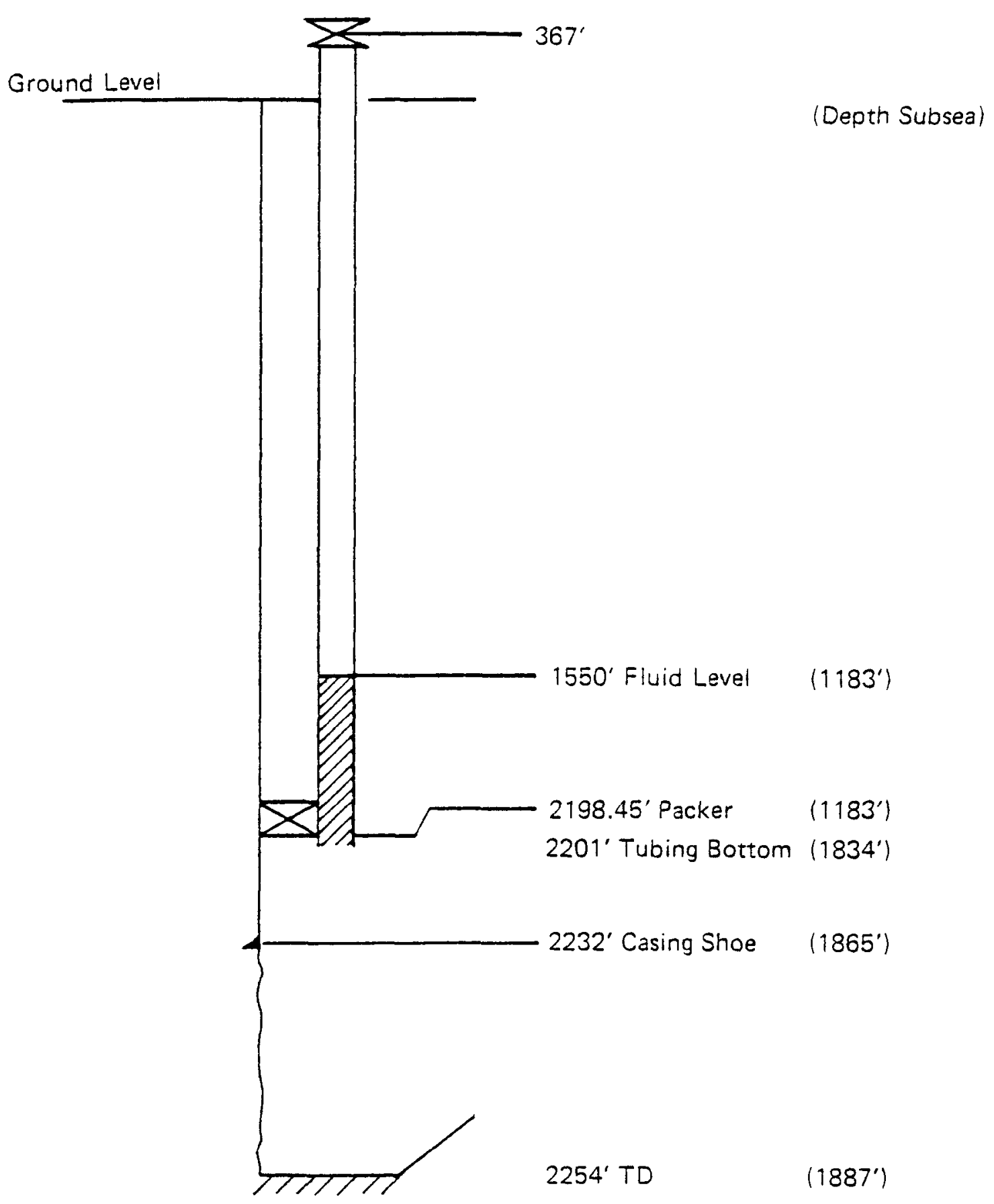

Figure 5. Profile of Well 9-3, October 17, 1979. 


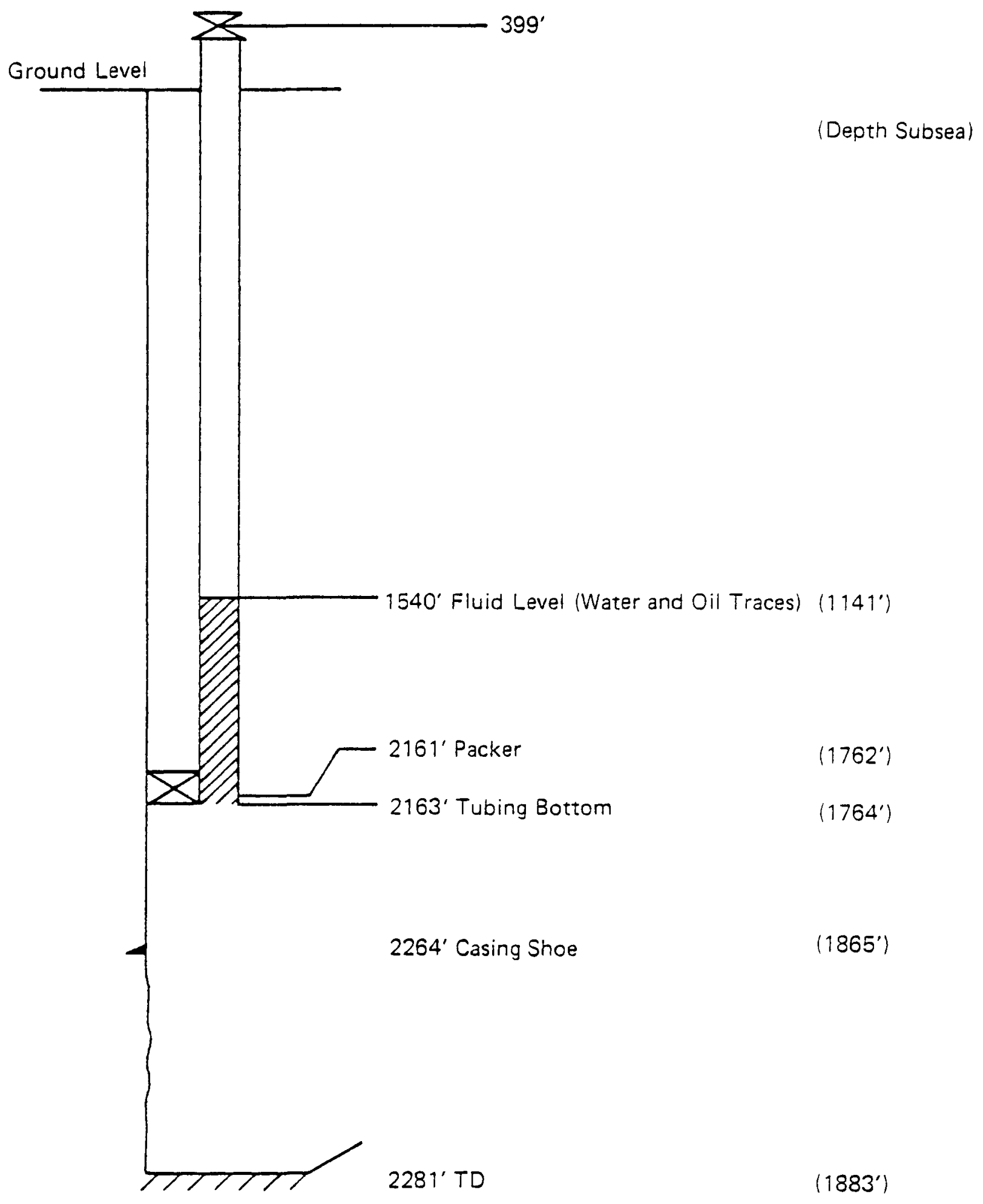

Figure 6. Profile of Well 10.1, October 18, 1979. 


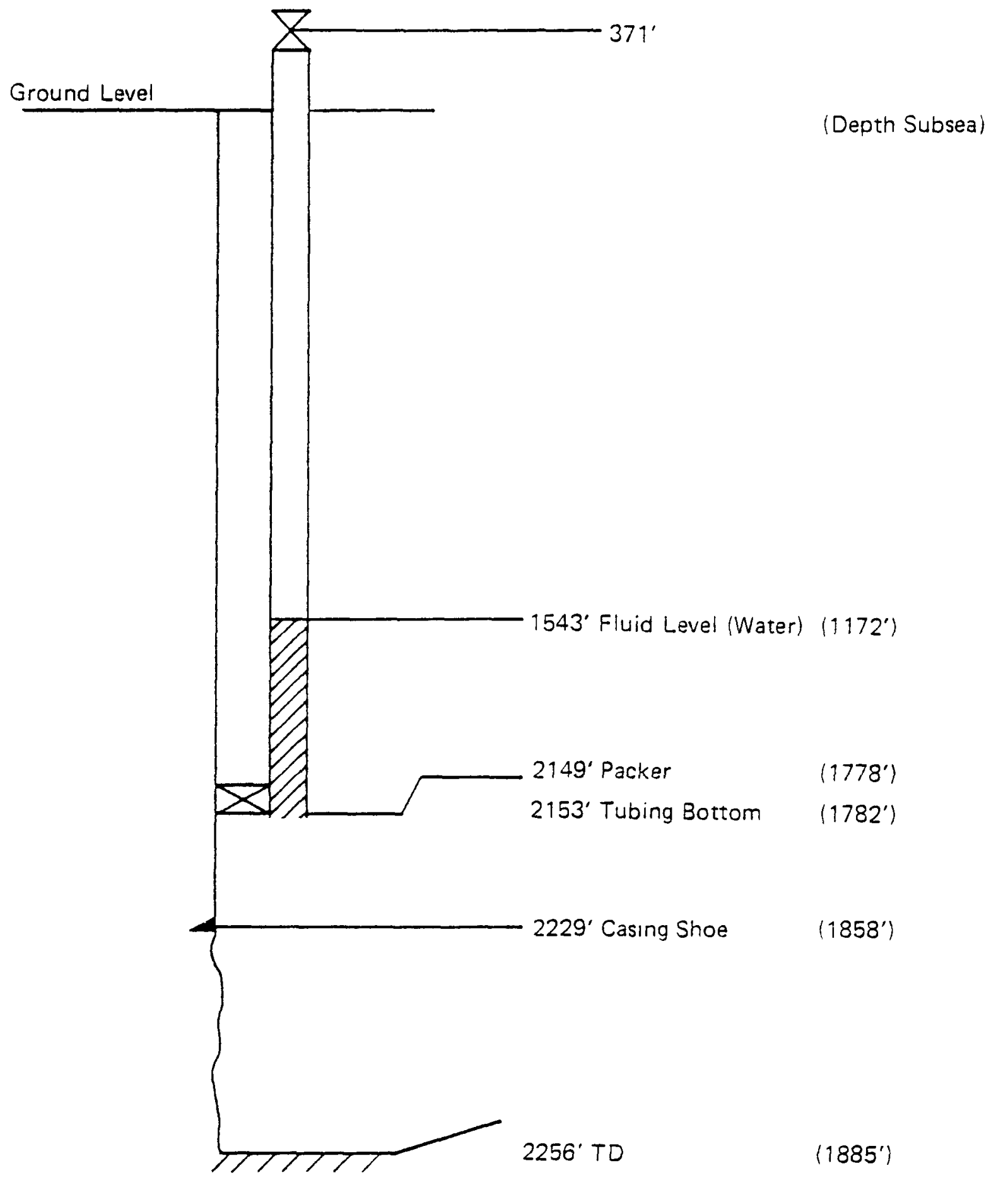

Figure 7. Profile of Well 10-3, October 19, 1979. 


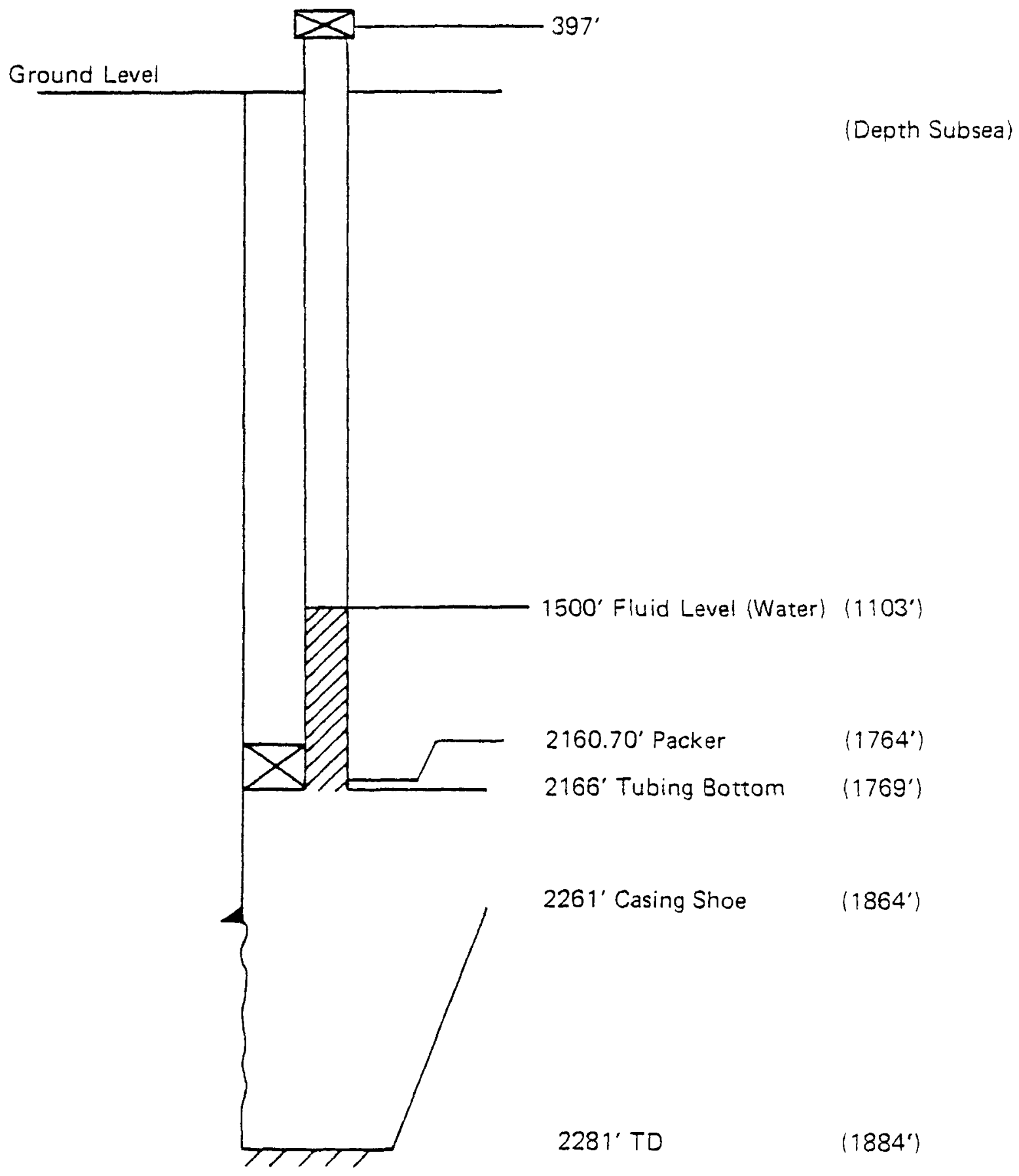

Figure 8. Profile of Well 12-4, October 17, 1979. 
DATE : October 19, 1979

DEPTH : 2270 feet subsurface

\begin{tabular}{|c|c|c|c|c|}
\hline $\mathrm{TI} \mathscr{V} \mathrm{E}$ & $\begin{array}{l}\text { HOURS } \\
\text { FROM } \\
\text { START }\end{array}$ & $\begin{array}{c}\text { TIME } \\
\text { DEFLECTION } \\
\text { (INCHES) }\end{array}$ & $\begin{array}{l}\text { PRESSURE } \\
\text { DEFLECTION } \\
\text { (INCHES) }\end{array}$ & $\begin{array}{c}\text { BOTTOM-HOLE } \\
\text { PRESSURE } \\
\text { (pSig) }\end{array}$ \\
\hline 1630 & 0 & 0 & 0.490 & 374.4 \\
\hline 1730 & 1.0 & 0.130 & 0.4905 & 374.8 \\
\hline 1830 & 2.0 & 0.260 & 0.4903 & 374.65 \\
\hline 1930 & 3.0 & 0.390 & 0.4896 & 374.25 \\
\hline 2030 & 4.0 & 0.520 & 0.489 & 373.7 \\
\hline 2130 & 5.0 & 0.650 & 0.488 & 372.9 \\
\hline 2230 & 6.0 & 0.780 & 0.4872 & 372.3 \\
\hline 2330 & 7.0 & 0.910 & 0.4865 & 371.8 \\
\hline \multicolumn{5}{|c|}{$10 / 20 / 79$} \\
\hline 0030 & 8.0 & 1.040 & 0.4855 & 371.0 \\
\hline 0130 & 9.0 & 1.170 & 0.4847 & 370.4 \\
\hline 0230 & 10.0 & 1.300 & 0.4835 & 369.5 \\
\hline 0330 & 11.0 & 1.430 & 0.4825 & 368.8 \\
\hline 0430 & 12.0 & 1.560 & 0.4817 & 368.1 \\
\hline 0530 & 13.0 & 1.690 & 0.4205 & 367.2 \\
\hline 0630 & 14.0 & 1.820 & 0.4795 & 368.5 \\
\hline
\end{tabular}


TABLE 2

AMERADA BOTTOM-HOLE PRESSURE MEASUREMENTS FOR WELL 9-2

DATE: October 18,1979

DEPTH: 2270 feet subsurface

\begin{tabular}{|c|c|c|c|c|}
\hline TIME' & $\begin{array}{l}\text { HOURS } \\
\text { FRUM } \\
\text { START }\end{array}$ & $\begin{array}{c}\text { TIME } \\
\text { DEFLECTION } \\
(\text { INCHES ) }\end{array}$ & $\begin{array}{l}\text { PRESSURE } \\
\text { DEFLECTION } \\
\text { (INCHES) }\end{array}$ & $\begin{array}{c}\text { BO'TTOM-HOLE } \\
\text { PRESSURE } \\
\text { (psig) }\end{array}$ \\
\hline 0900 & 0 & 0 & 0.433 & 331.1 \\
\hline 0915 & 0.25 & 0.0296 & 0.433 & 331.1 \\
\hline 0930 & 0.5 & 0.0592 & 0.4328 & 330.9 \\
\hline 0945 & 0.75 & 0.0888 & 0.4325 & 330.75 \\
\hline 1000 & 1.0 & 0.1185 & 0.432 & 330.1 \\
\hline 1030 & 1.5 & 0.1777 & 0.4317 & 330.1 \\
\hline 1100 & 2.0 & 0.2370 & 0.4317 & 330.1 \\
\hline 1130 & 2.5 & 0.2962 & 0.4317 & 330.1 \\
\hline 1200 & 3.0 & 0.3555 & 0.4317 & 330.1 \\
\hline 1230 & 3.5 & 0.4147 & 0.4317 & 330.1 \\
\hline 1300 & 4.0 & 0.4740 & 0.4317 & 330.0 \\
\hline 1330 & 4.5 & 0.5333 & 0.4315 & 330.0 \\
\hline 1400 & 5.0 & 0.5925 & 0.4312 & 329.85 \\
\hline 1430 & 5.5 & 0.6517 & 0.4312 & 329.85 \\
\hline 1500 & 6.0 & 0.7110 & 0.4312 & 329.85 \\
\hline
\end{tabular}


TABLE 3

AMERADA BOTTOM-HOLE PRESSURE MEASUREMENTS FOR WELL 9-3

DATE: October 17,1979

LEPTH : 2241 feet subsurface

\begin{tabular}{|c|c|c|c|c|}
\hline TIME & $\begin{array}{l}\text { HOURS } \\
\text { FKONI } \\
\text { START }\end{array}$ & $\begin{array}{c}\text { T'IME } \\
\text { DEFLECTION } \\
\text { ( INCHES) }\end{array}$ & $\begin{array}{l}\text { PRESSURE } \\
\text { DEFLECTION } \\
\text { ( INCHES ) }\end{array}$ & $\begin{array}{c}\text { BOTTOM-HOLE } \\
\text { PRESSURE } \\
\text { (psig) }\end{array}$ \\
\hline 1025 & 0 & 0 & 0.362 & 277.2 \\
\hline 1030 & 5 min. & 0.0108 & 0.3635 & 278.35 \\
\hline 1035 & $10 \mathrm{~min}$. & 0.0216 & 0.3636 & 278.4 \\
\hline 1040 & 0.25 & 0.0324 & 0.3636 & 278.4 \\
\hline 1045 & 20 min. & 0.0433 & 0.3636 & 278.4 \\
\hline 1050 & 25 min. & 0.0541 & 0.3636 & 278.4 \\
\hline 1055 & 0.5 & 0.0649 & 0.3636 & 278.4 \\
\hline 1110 & 1.75 & 0.0973 & 0.3636 & 278.4 \\
\hline 1125 & 1.0 & 0.1298 & 0.3636 & 278.4 \\
\hline 1140 & 1.25 & 0.1622 & 0.3636 & 278.4 \\
\hline 1155 & 1.50 & 0.1947 & 0.3636 & 278.4 \\
\hline 1210 & 1.75 & 0.2271 & 0.3636 & 278.4 \\
\hline 1225 & 2.0 & 0.2596 & 0.3636 & 278.4 \\
\hline 1255 & 2.5 & 0.3245 & 0.3636 & 278.4 \\
\hline 1325 & 3.0 & 0.3894 & 0.3636 & 278.4 \\
\hline 1355 & 3.5 & 0.4245 & 0.3636 & 278.4 \\
\hline 1425 & 4.0 & 0.5191 & 0.3636 & 278.4 \\
\hline 1455 & 4.5 & 0.5840 & 0.3636 & 278.4 \\
\hline 1525 & 5.0 & 0.6489 & 0.3636 & 278.4 \\
\hline 1550 & $\begin{array}{r}5 \text { hrs. } \\
25 \text { min. }\end{array}$ & 0.7030 & 0.3636 & 278.4 \\
\hline
\end{tabular}




\section{TABLE 4}

AMERADA BOTTOM-HOLE PRESSURE MEASUREMENTS FOR WELL 10-1

DATE : October 18, 1979

DEPTH: 2272 feet subsurface

\begin{tabular}{|c|c|c|c|c|}
\hline TIME & $\begin{array}{l}\text { HOURS } \\
\text { FROM } \\
\text { START }\end{array}$ & $\begin{array}{c}\text { TIME } \\
\text { DEFLECTION } \\
\text { (INCHES) }\end{array}$ & $\begin{array}{l}\text { PRESSURE } \\
\text { DEFLECTION } \\
\text { (INCHES) }\end{array}$ & $\begin{array}{c}\text { BOTTOM-HOLE } \\
\text { PRESSURE } \\
\text { (pSig) }\end{array}$ \\
\hline 1710 & 0 & 0 & 0.4098 & 313.6 \\
\hline 1715 & $5 \mathrm{~min}$ & 0.0110 & 0.4106 & 314.0 \\
\hline 1720 & 10 min. & 0.0221 & 0.4106 & 314.0 \\
\hline 1725 & $15 \mathrm{~min}$. & 0.0331 & 0.4106 & 314.0 \\
\hline 1730 & $20 \mathrm{~min}$. & 0.0441 & 0.4106 & 314.0 \\
\hline 1735 & 25 min. & 0.0552 & 0.4106 & 314.0 \\
\hline 1740 & 0.5 & 0.0662 & 0.4106 & 314.0 \\
\hline 1810 & 1.0 & 0.1324 & 0.4103 & 313.8 \\
\hline 1840 & 1.5 & 0.1986 & 0.4102 & 313.75 \\
\hline 1910 & 2.0 & 0.2648 & 0.410 & 313.0 \\
\hline 1940 & 2.5 & 0.3311 & 0.410 & 313.0 \\
\hline 2010 & 3.0 & 0.3973 & 0.410 & 313.0 \\
\hline 2040 & 3.5 & 0.4635 & 0.4102 & 313.75 \\
\hline \multirow[t]{2}{*}{2110} & 4.0 & 0.5297 & 0.4102 & 313.75 \\
\hline & 4.5 & 0.5959 & $0: 4102$ & 313.95 \\
\hline 2210 & 5.0 & 0.6622 & 0.4102 & 313.75 \\
\hline 2310 & 6.0 & 0.7946 & 0.4104 & 313.85 \\
\hline
\end{tabular}


TABLE 4 (CONTINUED)

\begin{tabular}{llclc}
\hline TIME & $\begin{array}{l}\text { HOURS } \\
\text { START }\end{array}$ & $\begin{array}{c}\text { TIME } \\
\text { DELECTION } \\
\text { (INCHES) }\end{array}$ & $\begin{array}{c}\text { PRESSURE } \\
\text { DEFLECTION } \\
\text { (INCHES) }\end{array}$ & $\begin{array}{c}\text { BOTTOM-HOLE } \\
\text { PRESSURE } \\
\text { (pSIg) }\end{array}$ \\
\hline $10 / 19 / 79$ & & & & 314.05 \\
0010 & 7.0 & 0.9270 & 0.4107 & 314.4 \\
0110 & 8.0 & 1.0594 & 0.411 & 314.8 \\
0210 & 9.0 & 1.1919 & 0.4115 & 315.2 \\
0310 & 10.0 & 1.3243 & 0.412 & 315.9 \\
0410 & 11.0 & 1.4567 & 0.413 & 316.2 \\
0510 & 12.0 & 1.5892 & 0.4134 & 316.5 \\
0610 & 13.0 & 1.7216 & 0.4138 & 316.7 \\
0700 & 13 hrs & 1.8320 & 0.414 & \\
\hline
\end{tabular}


TABLE 5

AMERADA BOTTOM-HOLE PRESSURE MEASUREMENTS FOR WELL 10-3

DATE: October 19, 1979

DEPTH : 2250 feet subsurface

\begin{tabular}{|c|c|c|c|c|}
\hline TIME & $\begin{array}{l}\text { HOURS } \\
\text { FROM } \\
\text { START }\end{array}$ & $\begin{array}{c}\text { TIME } \\
\text { DEFLECTION } \\
\text { (INCHES) }\end{array}$ & $\begin{array}{l}\text { PRESSURE } \\
\text { DEFLECTION } \\
\text { (INCHES) }\end{array}$ & $\begin{array}{c}\text { BOTTOM-HOLE } \\
\text { PRESSURE } \\
\text { (psig) }\end{array}$ \\
\hline 0900 & نे & 0 & 0.3825 & 292.8 \\
\hline 0915 & 0.25 & 0.0159 & 0.383 & 293.2 \\
\hline 0930 & 0.5 & 0.0318 & 0.3832 & 293.45 \\
\hline 0945 & 0.75 & 0.0477 & 0.3834 & 293.6 \\
\hline 1000 & 1.0 & 0.0637 & 0.3834 & 293.6 \\
\hline 1030 & 1.5 & 0.0955 & 0.3834 & 293.6 \\
\hline 1100 & 2.0 & 0.1273 & 0.3834 & 293.6 \\
\hline 1130 & 2.5 & 0.1592 & 0.3834 & 293.6 \\
\hline 1200 & 3.0 & 0.1910 & 0.3834 & 293.6 \\
\hline 1230 & 3.5 & 0.2228 & 0.3834 & 293.6 \\
\hline 1300 & 4.0 & 0.2547 & 0.3834 & 293.6 \\
\hline 1330 & 4.5 & 0.2865 & 0.3834 & 293.6 \\
\hline 1400 & 5.0 & 0.3183 & 0.3834 & 293.6 \\
\hline 1430 & 5.5 & 0.3502 & 0.3834 & 293.6 \\
\hline 1500 & 6.0 & 0.3820 & 0.3834 & 293.6 \\
\hline
\end{tabular}


TABLE 6

AMERADA BOTTOM-HOLE PRESSURE MEASUREMENTS FOR WELL 12-4

DATE: October 17, 1979

DEPTH: 2259 feet subsurface

\begin{tabular}{lcccc}
\hline TIME & $\begin{array}{c}\text { HOURS } \\
\text { FROM } \\
\text { START }\end{array}$ & $\begin{array}{c}\text { TIME } \\
\text { DEFLECTION } \\
\text { (INCHES) }\end{array}$ & $\begin{array}{c}\text { PRESSURE } \\
\text { DEFLECTION } \\
\text { (INCHES) }\end{array}$ & $\begin{array}{c}\text { BOTTOM-HOLE } \\
\text { PRESSURE } \\
\text { (PSig) }\end{array}$ \\
\hline 1734 & 0 & 0 & 0.4305 & 329.3 \\
1739 & 5 min. & 0.0111 & 0.4306 & 329.35 \\
1744 & 10 min. & 0.0221 & 0.4307 & 329.4 \\
1749 & 0.25 & 0.0332 & 0.4307 & 329.4 \\
1754 & 20 min. & 0.0442 & 0.4307 & 329.4 \\
1759 & 25 min. & 0.0552 & 0.4307 & 329.4 \\
1804 & 0.5 & 0.0663 & 0.4307 & 329.4 \\
1819 & 0.75 & 0.0995 & 0.4307 & 329.4 \\
1834 & 1.0 & 0.1326 & 0.4307 & 329.4 \\
1849 & 1.25 & 0.1658 & 0.4307 & 329.4 \\
1904 & 1.50 & 0.1989 & 0.4307 & 329.4 \\
1919 & 1.75 & 0.2322 & 0.4307 & 329.4 \\
1934 & 2.0 & 0.2635 & 0.4307 & 329.4 \\
2034 & 3.0 & 0.3980 & 0.4307 & 329.4 \\
2134 & 4.0 & 0.5307 & 0.4307 & 329.4 \\
2234 & 5.0 & 0.6634 & 0.4306 & 329.35 \\
2334 & 6.0 & 0.7961 & 0.4306 & 239.35 \\
\hline
\end{tabular}


TABLE 6 (CONTINUED)

\begin{tabular}{lcccc}
\hline TIME & $\begin{array}{c}\text { HOURS } \\
\text { FROM } \\
\text { START }\end{array}$ & $\begin{array}{c}\text { TIME } \\
\text { DEFLECTION } \\
\text { (INCHES) }\end{array}$ & $\begin{array}{c}\text { PRESSURE } \\
\text { DEFLECTION } \\
\text { (INCHES) }\end{array}$ & $\begin{array}{c}\text { BOTTOM-HOLE } \\
\text { PRESSURE } \\
\text { (PSig) }\end{array}$ \\
\hline $10 / 18 / 79$ & & & & \\
0034 & 7.0 & 0.9288 & 0.4306 & 329.35 \\
0124 & 8.0 & 1.0614 & 0.4306 & 329.35 \\
0234 & 9.0 & 1.1942 & 0.4306 & 329.35 \\
0334 & 10.0 & 1.3268 & 0.4306 & 329.35 \\
0434 & 11.0 & 1.4595 & 0.4305 & 329.3 \\
0534 & 12.0 & 1.5922 & 0.4304 & 329.25 \\
0634 & 13.0 & 1.7249 & 0.4304 & 329.25 \\
0700 & 13 hrs. & 1.7825 & 0.4304 & 329.25 \\
\hline
\end{tabular}


TABLE 7

RESULTS OF STATIC PRESSURE MEASUREMENTS

AMERADA MEASUREMENTS

\begin{tabular}{llllll}
\hline $\begin{array}{l}\text { INJECTION WELL } \\
\text { NUMBER }\end{array}$ & $\begin{array}{l}\text { DEPTH } \\
\text { SUBSURFACE } \\
(\mathrm{ft})\end{array}$ & $\begin{array}{l}\text { GROUND } \\
\text { LEVEL } \\
(\mathrm{ft})\end{array}$ & $\begin{array}{l}\text { DEPTH } \\
\text { SUBSEA } \\
(\mathrm{ft})\end{array}$ & $\begin{array}{l}\text { STATIC } \\
\text { PRESSURE } \\
(\mathrm{psig})\end{array}$ & $\begin{array}{l}\text { ATATIC PRESSURE } \\
\text { SUBSEA }\end{array}$ \\
\hline $9-2$ & 2270 & 397 & 1873 & 330 & 314.5 \\
$10-1$ & 2272 & 399 & 1873 & 313 & 297.5 \\
$10-3$ & 2250 & 371 & 1879 & 293.6 & 275.5 \\
$6-4$ & 2270 & 393 & 1877 & 366 & 348.8 \\
$12-4$ & 2259 & 397 & 1862 & 329.4 & 318.6 \\
$9-3$ & 2241 & 367 & 1874 & 278.4 & 262.5 \\
\hline
\end{tabular}

ECHOMETER MEASUREMENTS

\begin{tabular}{|c|c|c|c|c|c|}
\hline $\begin{array}{l}\text { PRODUCTION } \\
\text { WELL } \\
\text { NUMBER }\end{array}$ & $\begin{array}{l}\text { DEPTH OF } \\
\text { LIQUID } \\
\text { LEVEL } \\
\text { SUBSURFACE } \\
\text { (ft) }\end{array}$ & $\begin{array}{l}\text { GROUND } \\
\text { LEVEL } \\
(\mathrm{ft})\end{array}$ & $\begin{array}{l}\text { DEPTH OF } \\
\text { LIQUID } \\
\text { LEVEL } \\
\text { SUBSEA } \\
\text { (ft) }\end{array}$ & $\begin{array}{l}\text { LIQUID } \\
\text { LEVEL } \\
\text { ABOVE } \\
1831 \text { ft } \\
\text { SUBSEA } \\
\text { (Et) }\end{array}$ & $\begin{array}{l}\text { STATIC } \\
\text { PRESSURE } \\
\text { AT } \\
\text { I831 ft } \\
\text { SUBSEA } \\
\text { (psig) }\end{array}$ \\
\hline $\begin{array}{r}9-1 \\
9-4 \\
10-1 \\
10-4 \\
10-5\end{array}$ & $\begin{array}{l}1581 \\
1495 \\
1616 \\
1611 \\
1439\end{array}$ & $\begin{array}{l}402 \\
367 \\
401 \\
368 \\
393\end{array}$ & $\begin{array}{l}1179 \\
1128 \\
1215 \\
1243 \\
1046\end{array}$ & $\begin{array}{l}652 \\
703 \\
616 \\
588 \\
785\end{array}$ & $\begin{array}{ll}299^{a} & 216^{b} \\
322^{a} & 236^{b} \\
283^{a} & 202^{b} \\
270 a & 191^{b} \\
359^{a} & 268^{b}\end{array}$ \\
\hline
\end{tabular}

$a_{\text {Assuming a water-filled annulus }}$

$b_{\text {Assuming an oil-filled annulus }}$ 
gradient in this direction is approximately $0.019 \mathrm{psig/ft.}$ The corresponding fluid drift is less than $0.02 \mathrm{ft} / \mathrm{day}$. This result, if accurate, indicates that field-wide drift should not significantly influence the flow of injected fluids during the pilot flood.

\subsection{Interference Test Program}

We outlined a program of interference tests to help determine the degree of communication between wells in the pilot area. The program consists of two tests:

Test 1: Inject water for four days at $600 \mathrm{bbl} / \mathrm{day}$. Record pressure responses at all other wells for six days, using pressure bombs in the other injectors and echometers in the producers (since pumps and rods already in place will make it difficult to run pressure bombs there).

Test 2: Inject water for 4 days at $600 \mathrm{bbl} / \mathrm{day}$ in injector 9-3, again recording all changes in injection rate. Record pressure responses at all other wells except well 10-1 for 6 days as in Test 1 . These tests are depicted in Figure 9.

The proposed injection rate of $600 \mathrm{bbl} / \mathrm{day}$ should suffice to attain a pressure difference of at least 15 psig, which should yield an unambiguous pressure response at the observation wells. The proposed observation times are based on an estimate of pressure change using the equation for the pressure response to a single well in an infinite reservoir:

$$
\Delta p=\frac{q^{\mu}}{4 \pi k h} E i\left(-\frac{\phi \mu C r^{2}}{4 k t}\right)
$$

where

$$
E i(-x)=-\int_{x}^{\infty} \frac{\exp (-u) d u}{u}
$$

Equation 2-1 is expressed in Darcy units; see Matthews and Russell, Pressure Buildup and Flow Tests in Wells, SPE Monograph Volume 1. Assuming the (Darcy unit) values:

$$
\begin{aligned}
& k=0.2 \text { darcies } \\
& h=1200 \mathrm{~cm} \\
& \mu=10 \mathrm{cp} \\
& \mathrm{C}=1.45 \times 10^{-4} \text { atm }^{-1}
\end{aligned}
$$


gives the equation

$$
\Delta p=0.2488 \mathrm{Ei}\left(3.281 \times 10^{4} \mathrm{r}^{2} / \mathrm{t}\right)
$$

in oilfield units. This estimate of pressure change is plotted against time for the four appropriate values of $r$ in Figure 10. 


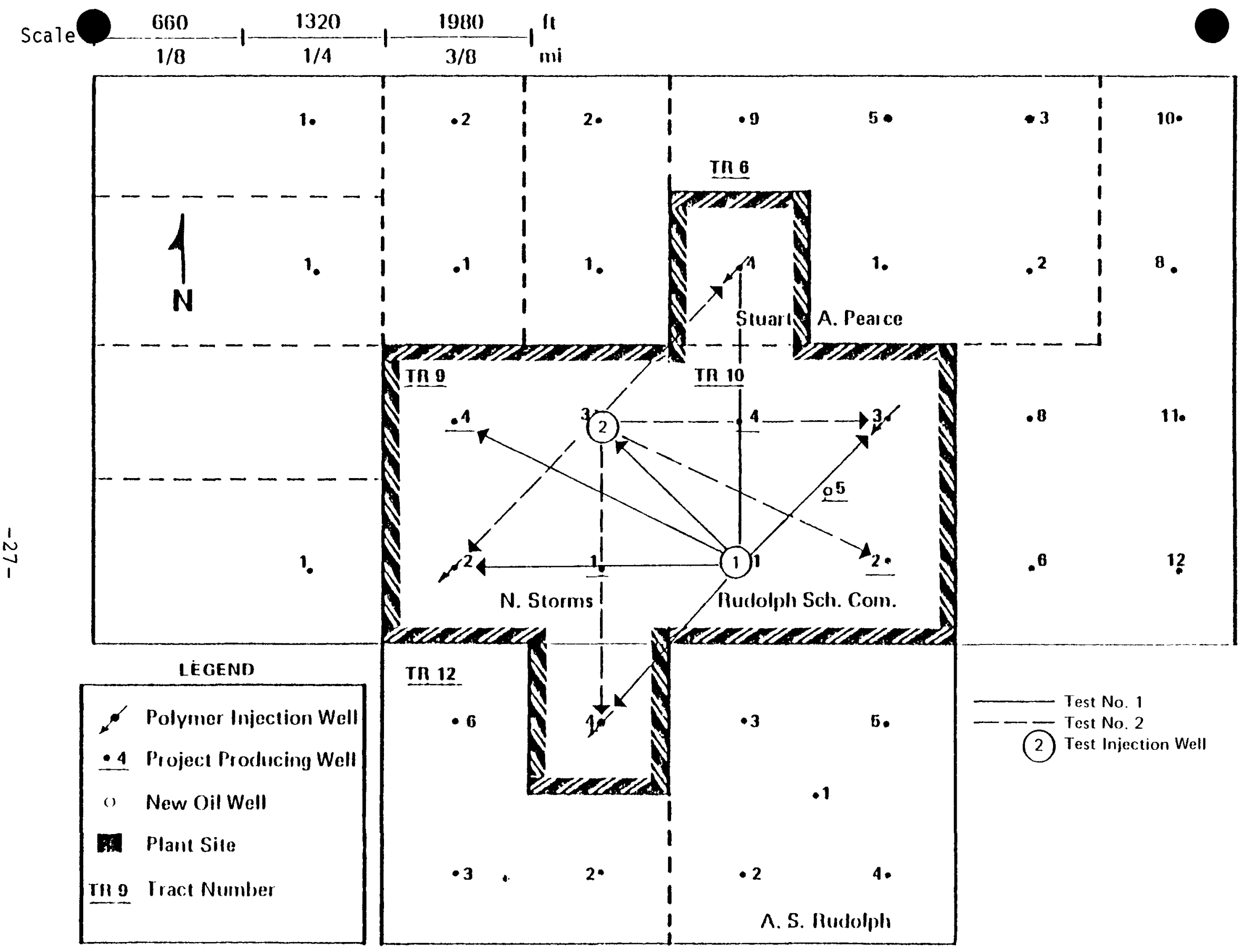

Figure 9. Geometry of proposed interference tests. 


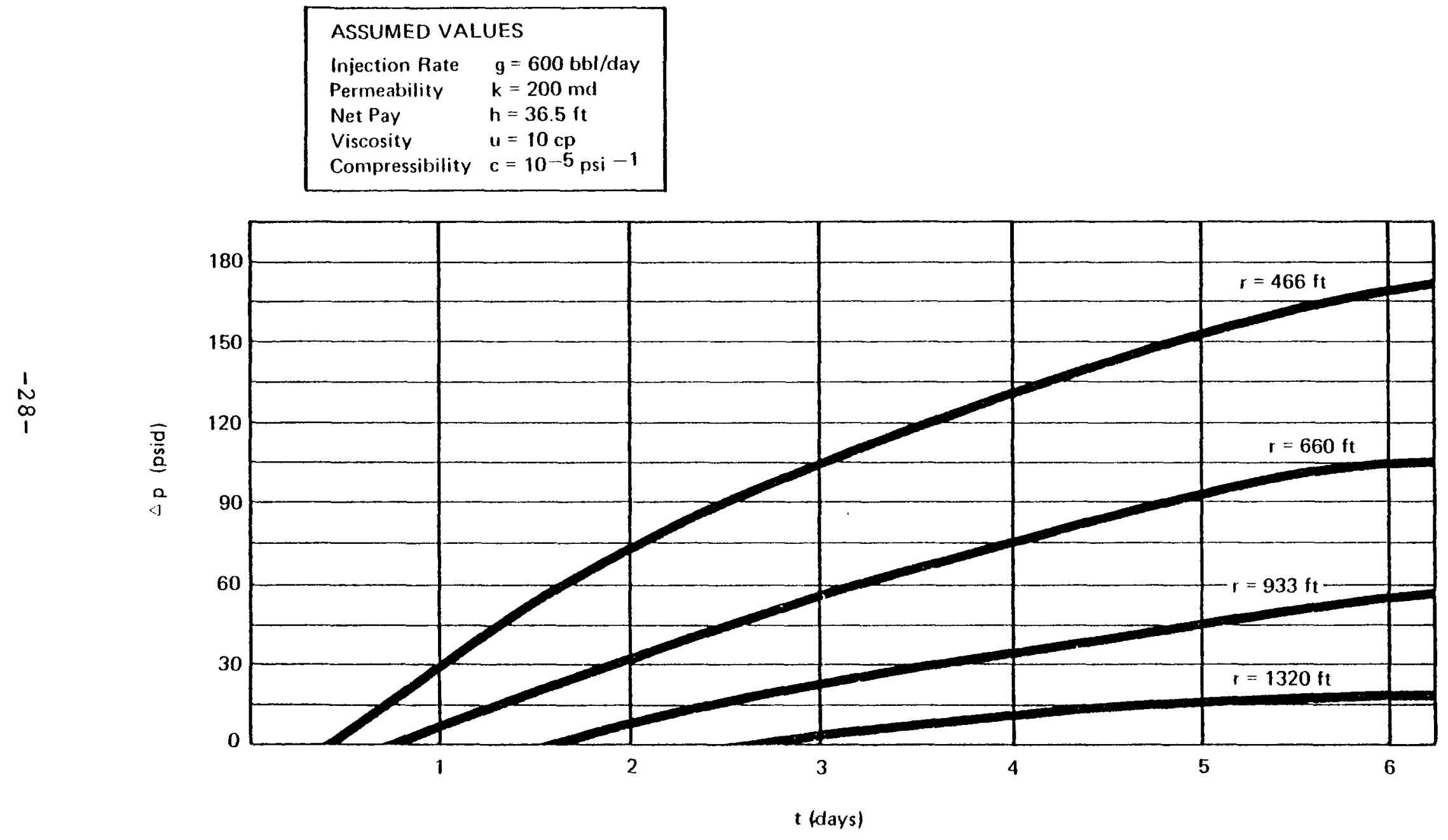

Figure 10. Estimated pressure change, as a function of distance and time, for proposed interference tests. 


\author{
SECTION THREE \\ POLYMER SELECTION AND SLUG DESIGN
}

\begin{abstract}
During 1979 Energy Resources conducted a series of laboratory tests to determine the physical and chemical characteristics of several polymers chosen as candidates for field use. These tests examined the compatibility of polymers with waters from the Waltersburg formation and from the Little Wabash River, rheologic and retentive behavior of polymer solutions in reservoir cores, and polymer solution filterability. Data from this program and cost estimates supported the final selection of polymer and the design of a graded slug for injection.
\end{abstract}

Two basic types of polymers were examined: polyacrylamides (and their salts) and polysaccharides or biopolymers. Twelve polymers from nine manufacturers were evaluated; eight of the polymers were polyacrylamides and four were polysaccharides. The polymers are identified in this report by an alphabetic index indicating manufacturer, product, state, and weight percent as listed in Table 8 . In this scheme different polymers from the same manufacturer are numbered, e.g., $\mathrm{C} 1$ and $\mathrm{C} 2$ for American Cyanamid polymers with different molecular weights.

\title{
3.I Compatibility with River and Formation waters
}

The compatibility of polymers with the river and formation waters was evaluated in terms of sensitivity to salt, to mechanical shear, and to ancillary chemicals. Susceptibility to microbial attack, also an important consideration, is discussed in section 4.3.

The analyses of the formation water and water from the Little Wabash River appear in Table 9. We decided to use 100 percent river water for dilution of either polymer type because of incompatibilities between the river and formation waters. For example, precipitation of iron sulfide could result from the reaction of iron in the river water, which is eluted or dissolved from the rusted river water pumps and from the rusted river water line to Jim Haley's injection plant, with hydrogen sulfide, which is produced by sulfate reducing bacteria in the formation water. Most of the tests were performed in an $80 / 20$ synthetic mixture of river and formation waters based on the compositions Iisted in Table 9. This mixture was used to simulate conditions in the reservoir, where the injected 
TABLE 8

IDENTIFICATION OF POLYMERS BY MANUFACTURERS, PRODUCT TYPE, STATE AND WEIGH'T PERCENT

\begin{tabular}{|c|c|c|c|c|c|}
\hline & $\begin{array}{l}\text { POLY - } \\
\text { MER }\end{array}$ & $\begin{array}{l}\text { MANU- } \\
\text { FACTURER }\end{array}$ & PRODUCT & STATE & $\begin{array}{l}\text { ACTIVE } \\
\text { PRODUCT } \\
\text { (Wt \&) }\end{array}$ \\
\hline $\begin{array}{l}\mathrm{P} \\
\mathrm{O}\end{array}$ & $\mathrm{A}$ & Amoco & Sweepaid 103 & W/Oa Emulsion & 25 \\
\hline $\begin{array}{l}\mathrm{L} \\
\mathrm{Y}\end{array}$ & B & NALCO & NAL-FLO F HMWS & W/O Emulsion & 30 \\
\hline $\begin{array}{l}A \\
C \\
R\end{array}$ & $\begin{array}{l}\mathrm{Cl} \\
\mathrm{C} 2\end{array}$ & $\begin{array}{l}\text { American } \\
\text { Cyanamid }\end{array}$ & $\begin{array}{ll}\text { Cyanatrol } & 950 \mathrm{~S} \\
\text { Cyanatrol } & 960 \mathrm{~S}\end{array}$ & $\begin{array}{l}\text { W/O Emulsion } \\
\text { W/O Emulsion }\end{array}$ & $\begin{array}{l}30 \\
30\end{array}$ \\
\hline $\begin{array}{l}\text { Y } \\
\mathrm{A} \\
\mathrm{M}\end{array}$ & $D$ & $\begin{array}{l}\text { Allied } \\
\text { Colloid }\end{array}$ & $1100-L$ & W/O Emulsion & 50 \\
\hline $\begin{array}{l}I \\
D \\
E\end{array}$ & $\begin{array}{l}\text { E1 } \\
\text { E2 }\end{array}$ & $\begin{array}{l}\text { CORTb } \\
\text { CORT }\end{array}$ & $\begin{array}{ll}\text { N-Hance } & 335 \\
\text { N-Hance } & 330\end{array}$ & $\begin{array}{l}\text { Aqueous Log } \\
\text { Aqueous Log }\end{array}$ & $\begin{array}{l}30 \\
27\end{array}$ \\
\hline$\vec{S}$ & $\mathrm{~F}$ & Dow & $X D-30226.0$ & W/O Emulsion & 28 \\
\hline $\begin{array}{l}\mathrm{P} \\
\mathrm{O} \\
\mathrm{L}\end{array}$ & GI & Pfizer & Flocon 1035 & Broth & 2.7 \\
\hline $\begin{array}{l}Y \\
S \\
A\end{array}$ & G2 & Pfizer & Flocon 4880 & Broth & 5.7 \\
\hline $\begin{array}{l}\mathrm{C} \\
\mathrm{C}\end{array}$ & $\mathrm{H}$ & Abbott & & Broth & 2.75 \\
\hline $\begin{array}{l}\mathrm{H} \\
\mathrm{A} \\
\mathrm{R} \\
\mathrm{I} \\
\mathrm{D} \\
\mathrm{E} \\
\mathrm{S}\end{array}$ & $J$ & $\begin{array}{l}\text { Rhone- } \\
\text { Poulenc }\end{array}$ & Rhodopol & Dry & 88 \\
\hline
\end{tabular}

Water/oil.

bJoint venture company of Phillips Petroleum and Hercules. 
COMPOSITION OF FORMATION AND RIVER WATER IN STORMS POOL PROJECT

\begin{tabular}{|c|c|c|}
\hline CONSTITUENT & $\begin{array}{c}\text { WALTERSBURG } \\
\text { FORMATION } \\
\text { WATER } \\
\text { (pPm) }\end{array}$ & $\begin{array}{c}\text { LITTLE } \\
\text { WABASH RIVER } \\
\text { WATER } \\
\text { (ppm) }\end{array}$ \\
\hline Sodium & 13,715 & 18 \\
\hline Calcium & 732 & 23 \\
\hline Magnesium & 358 & 8 \\
\hline Chloride & 23,250 & 25 \\
\hline Sulfate & 7 & 5 \\
\hline Iron & 1 & 0 \\
\hline Bicarbonate & 403 & 110 \\
\hline Carbonate & 0 & 0 \\
\hline Total & 38,466 & 189 \\
\hline Total Iron & 1 & 9 \\
\hline Barium & 18 & 0 \\
\hline $\mathrm{H}_{2} \mathrm{~S}$ & 2.4 & 0 \\
\hline $\mathrm{pH}$ at $24^{\circ} \mathrm{C}$ & 6.8 & 7.1 \\
\hline Specific gravity at $24^{\circ} \mathrm{C}$ & 1.03 & 1.0 \\
\hline $\begin{array}{l}\text { Resistivity at } 24^{\circ} \mathrm{C} \\
\text { (ohm-m) }\end{array}$ & 0.2 & 43.0 \\
\hline $\begin{array}{l}\text { Turbidity (Nephelometric } \\
\text { Turbidity Units) }\end{array}$ & 54 & 77 \\
\hline
\end{tabular}


polymer solution will probably contact significant concentrations of formation brine even after a very efficient preflush. The iron content of the formation water was neglected in the manufacture of synthetic formation water because of precipitation problems which could occur in the oxidizing environment of the laboratory. These problems will not necessarily occur in the reducing conditions of the reservoir, even though all of the iron may not be removed from the injection water. The use of oxygen scavengers in the injection system will help prevent ferrogenic precipitation.

\subsubsection{Electrochemical Degradation}

The extreme sensitivity of the polyacrylamides to electrolytes is demonstrated by the electrochemical degradation factors listed in Table 10. The electrochemical degradation factor is the ratio of shear viscosities of polymers in river water to the viscosities of polymers in an $80 / 20 \mathrm{mix}$ of river and formation waters. Viscosities were measured in a Brookfield viscosometer with a UL adapter at a shear rate of $7.3 \mathrm{sec}^{-1}$ and $95^{\circ} \mathrm{F}$. The polyacrylamides are much more $v$ iscous than the polysaccharide at equivalent concentrations in fresh water but are less viscous than the polysaccharide in the saline water $(10,000 \mathrm{ppm}$ TDS ). The high molecular weight of the polyacrylamides, which is responsible for their high viscosity in fresh water, results from the reactive nature of the individual polymer molecules. The diffuse double layer generated by the high charge density of the reactive monomer units is compressed in the presence of high concentrations of uni- and polyelectrolytes. The collapse of the double layer lowers the electrostatic forces of repulsion and causes the polymer chain to ball up as a result of Van der Waals forces of attraction. Thus, the viscosity of the high molecular weight polyacrylamides drops, as illustrated in Figure 11, by an order or magnitude in the presence of uni- and polyelectrolytes at approximately $10,000 \mathrm{ppm}$ TDS. The viscosity of the polysaccharide $G$ is not affected by the presence of the electrolytes because of the lower charge density on the saccharide monomers. The relative insensitivity of xanthan gum broths to salt concentration is illustrated in the viscosity-concentration curves of polysaccharide $\mathrm{J}$ in concentrations of brine ranging from about $1,000 \mathrm{ppm}$ to roughly $40,000 \mathrm{ppm}$ in Figure 12 .

\subsubsection{Mechanical Degradation}

Figure 13 illustrates the viscous response of $500 \mathrm{ppm}$ solutions of the test polymers to shear at reservoir temperatures in 100 percent river water and an $80 / 20 \mathrm{mix}$ of river 
ELECTROCHEMICAL DEGRADATION OF 500 ppm ACTIVE POLYMER AT A SHEAR RATE OF $7.3 \mathrm{sec}^{-1}$ and $95^{\circ} \mathrm{F}$

\begin{tabular}{|c|c|c|c|}
\hline & & VISCOSITY IN & \\
\hline & $\begin{array}{l}\text { VISCOSITY } \\
\text { IN RIVER }\end{array}$ & $\begin{array}{l}80 / 20 \text { MIX OF } \\
\text { RIVER FORMATION }\end{array}$ & ELECTROCHEMICAL \\
\hline POLYMER & $\begin{array}{l}\text { WATER } \\
(\mathrm{cP})\end{array}$ & $\begin{array}{c}\text { WATERS } \\
(\mathrm{cp})\end{array}$ & $\begin{array}{c}\text { DEGRADATION } \\
\text { FACTOR }\end{array}$ \\
\hline
\end{tabular}

Polyacrylamides

$\begin{array}{llll}\text { A } & 36.3 & 2.6 & 14.0 \\ \text { B } & 49.8 & 4.3 & 11.6 \\ \text { C } & 43.0 & 2.5 & 17.2 \\ \text { D1 } & 64.0 & 3.6 & 17.8 \\ \text { D2 } & & 2.8 \mathrm{a} & \\ \text { D3 } & 2.5 & 11.2 \\ \text { E } & 42.4 & 3.8 & 14.5 \\ \text { F } & 62.3^{b} & 4.3 \mathrm{a} & \end{array}$

Polysaccharides

Gl

G2

JC
8.9

13.0

13.4

12.6
8.3
12.5
8.4
10.5
1.1

1.04

1.6

1.2

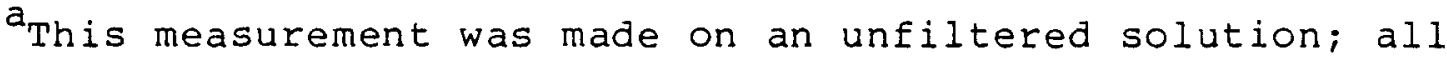
other solutions were filtered with a depth filter.

$b_{\text {The electrochemical degradation factor can be used for }}$ comparative purposes although the results of these tests are at $75^{\circ} \mathrm{F}$ and the other tests are at $95^{\circ} \mathrm{F}$.

${ }^{C}$ Dry polymer (all others are liquids or gels). 


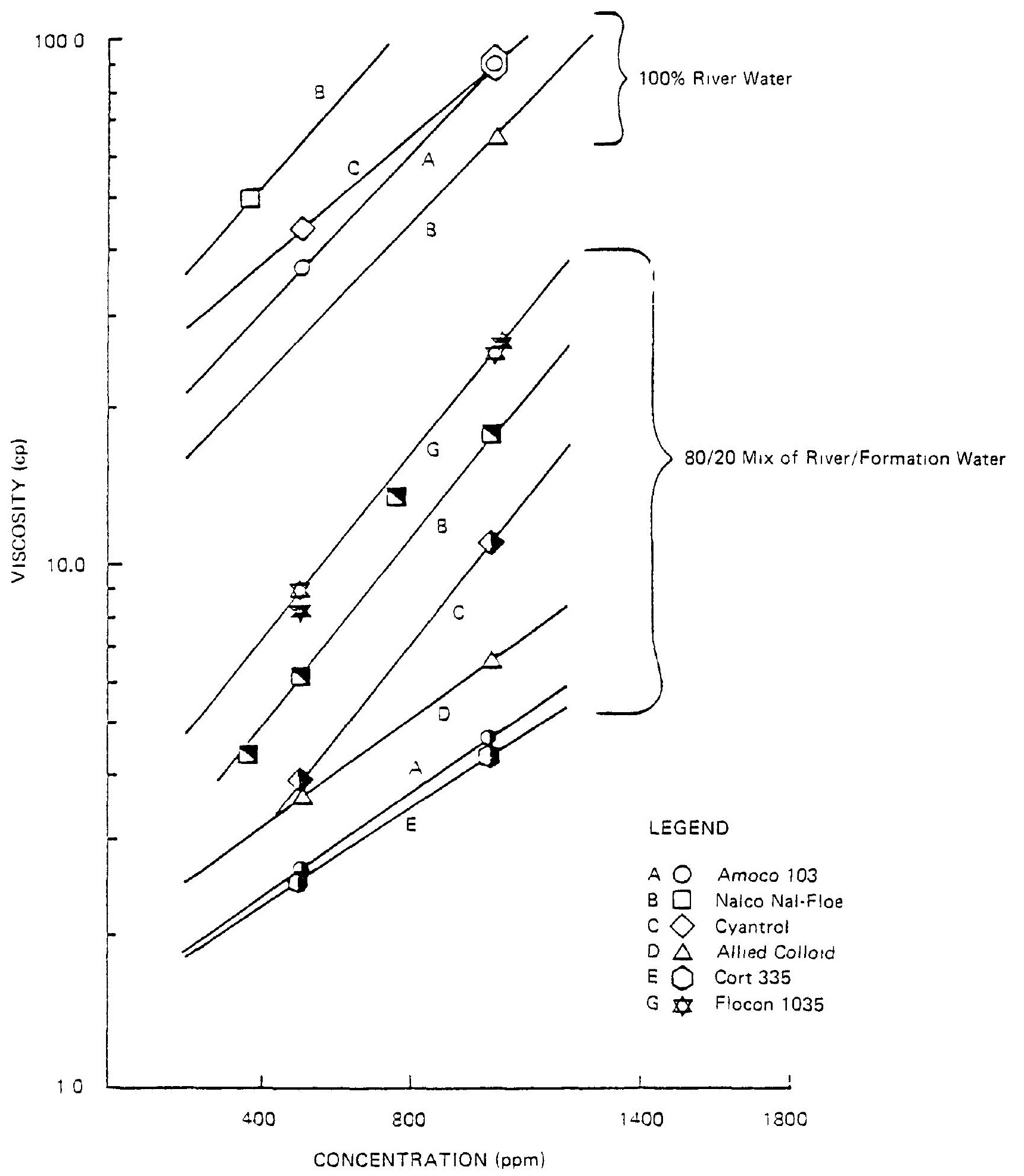

Figure 11 Viscosity as a function of polymer concentration in $100 \%$ river water and in $80 / 20 \mathrm{mix}$ of river and formation waters. 


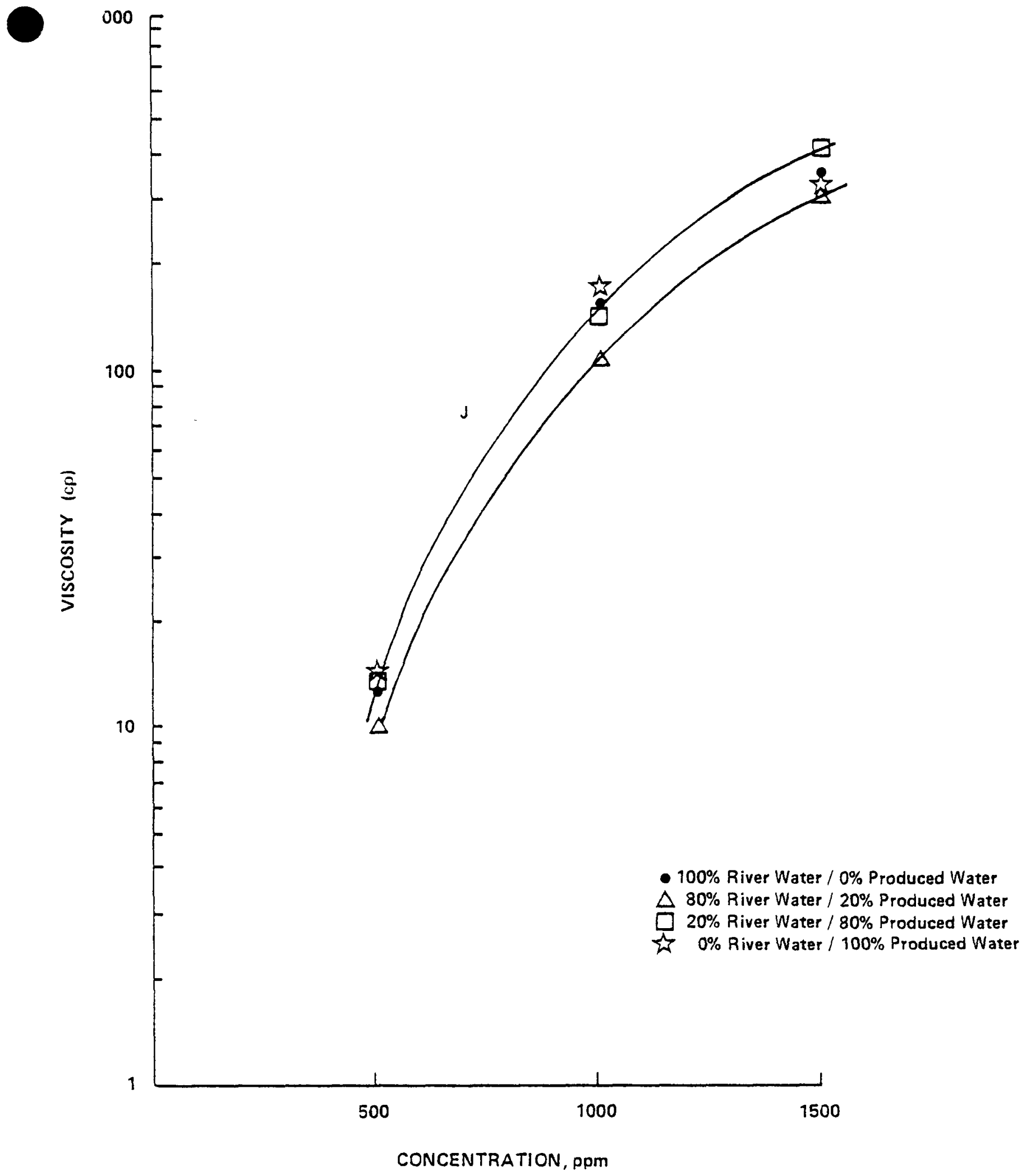

Figure 12. Viscosity as a function of concentration for biopolymer $\mathrm{J}$ at $95^{\circ} \mathrm{F}$ and $7.3 \mathrm{sec}^{-1}$ with salt concentration as a parameter. 


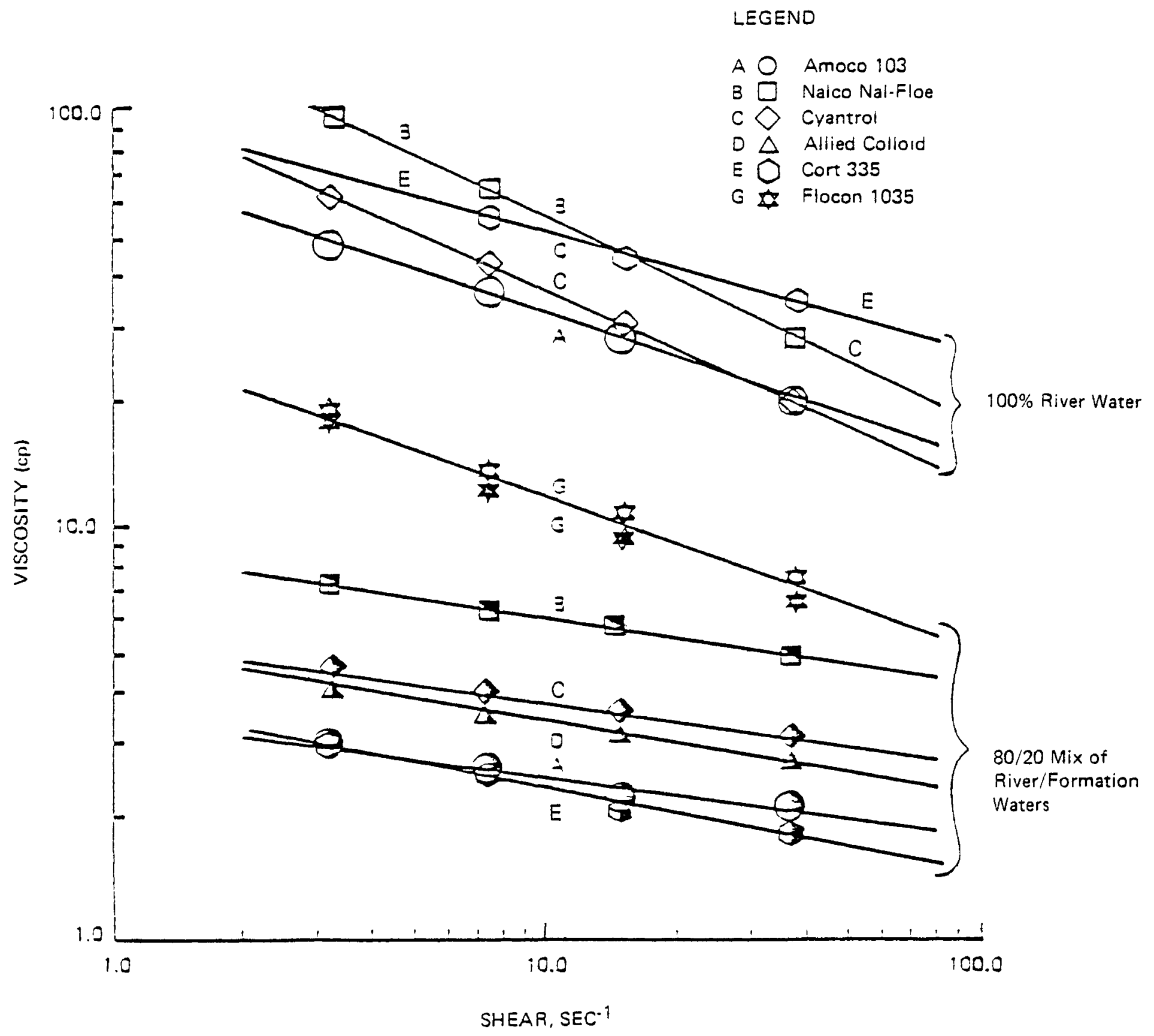

Figure 13. Viscosity at $500 \mathrm{ppm}$ as a function of shear with river water and with $80 / 20$ mix of river and formation waters. 
and formation waters. These data were measured by a Brookfield rotational viscosometer with a UL adapter. The sensitivity of the polymers to shear appears independent of the electrochemical environment. The independence of the shear-viscosity relationships and electrolyte concentration is further illustrated in Figure 14. The shear rate, $\tau$, in the porous medium is calculated from the following equation: ${ }^{1}$

$$
\tau=\frac{1.42 \times 10^{4} \times \mathrm{Q}}{\mathrm{A} \sqrt{\phi \mathrm{k}}}
$$

where $Q$ is the flow rate in cc/sec; $A$ is cross-sectional area in $\mathrm{cm}^{2} ; \mathrm{k}$ is the permeability in darcies, and $\phi$ is porosity, expressed as a fraction. Over the range of shear studied, the viscosity of the test polymers is reduced about 40 to 50 percent. Most of this reduction will occur at the high velocities experienced at the wellbore if the surface facilities are adequately designed to minimize mechanical shear.

The shear rate at the open-hole completions in the storms Pool is approximately $2,000 \mathrm{sec}^{-1}$ at an injection rate of $600 \mathrm{bbl} / \mathrm{day}$; the shear rate in the reservoir is approximately $20 \mathrm{sec}^{-1}$ at a reservoir rate of $1 \mathrm{ft} / \mathrm{day}$. The viscosity of polyacrylamide $B$ at the wellbore shear is approximately 44 percent of the viscosity at a typical laboratory shea = of $7.3 \mathrm{sec}^{-1}$, a value obtained from extrapolation along curve $B$ for the $80 / 20 \mathrm{mix}$ in Figure 13 . Experience in tie Wilmington field and in laboratory investigations ${ }^{2}$ suggests that some of the polyacrylamide viscosity reduction under increased shear will be irreversible on removal of the high shear field. The viscous response of the biopolymer to shear appears to be reversible.

Table 11 lists the screen factors of the polyacrylamides in 100 percent river water and an $80 / 20 \mathrm{mix}$ of river and formation waters at room temperature. The screen factor is defined as the ratio of the flow time for the polymer solution to the flow time of the appropriate solvent (water or brine) through a random stack of five 200-mesh SS screens. The screen factur is a measure of the viscoelastic response of the polymer and is more sensitive than viscosity to mechanical degradation. Thus the screen factor is a better measure of mechanical degradation than viscosity; this measurement is, however, polymer specific.

\footnotetext{
$1_{B}$. Sandiford, personal communication, October; 1978,

2Maerker, J.M. (1975), Shear degradation of partially hydrolyzed polyacrylamide solutions, Soc. Pet. Eng. J. (August) : 311 .
} 


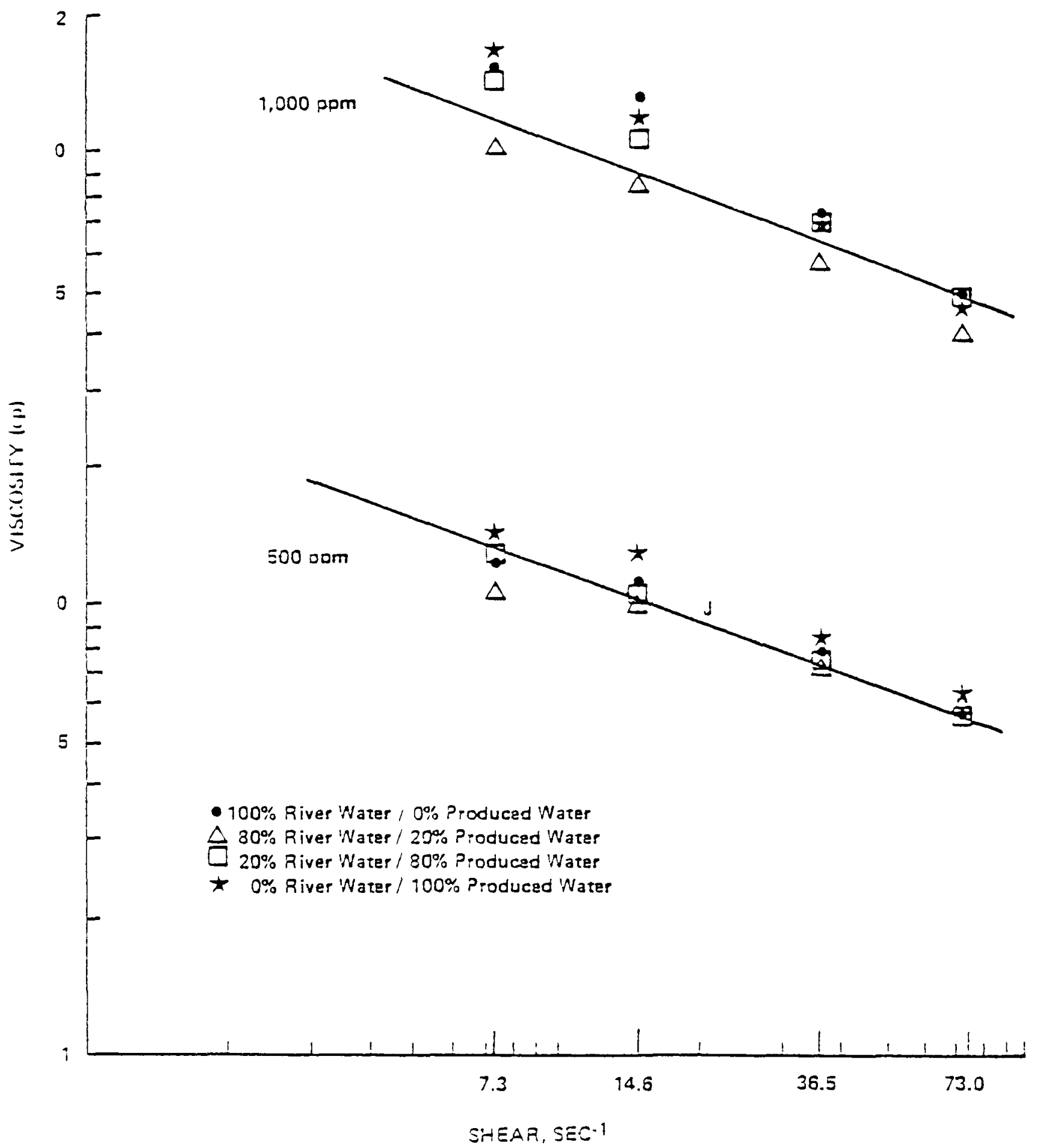

Figure 14. Viscosity as a function of shear for biopolymer $J$ at $95^{\circ} \mathrm{F}$ and 500 and $1,000 \mathrm{ppm}$ of active polymer concentration with salt concentration as a parameter. 
TABLE 11

VISCOELASTIC RESPONSE OF POLYMERS AS MEASURED BY SCREEN FACTOR

\begin{tabular}{|c|c|c|c|}
\hline & POLYMER & $\begin{array}{l}\text { SCREEN FACTOR } \\
\text { IN RIVER WATER } \\
\text { AT } 75^{\circ} \mathrm{F}\end{array}$ & $\begin{array}{c}\text { SCREEN FACTOR IN } \\
80 / 20 \text { MIX OF } \\
\text { RIVER/FORMATION WATERS } \\
\text { AT } 75^{\circ} \mathrm{F}\end{array}$ \\
\hline $\begin{array}{l}P \\
O\end{array}$ & $A$ & 11.66 & 7.01 \\
\hline $\begin{array}{l}\mathrm{L} \\
\mathrm{Y}\end{array}$ & $B$ & 25.70 & 18.10 \\
\hline $\begin{array}{l}\mathrm{A} \\
\mathrm{C}\end{array}$ & $\mathrm{C}$ & 6.62 & 2.84 \\
\hline $\begin{array}{l}R \\
Y\end{array}$ & $\mathrm{Dl}$ & 31.35 & $15.80 \mathrm{a}$ \\
\hline $\begin{array}{l}\mathrm{L} \\
\overline{\mathrm{A}}\end{array}$ & $\mathrm{D} 2$ & & 16.00 \\
\hline $\begin{array}{c}M \\
I\end{array}$ & D3 & & 14.46 \\
\hline $\begin{array}{l}D \\
E\end{array}$ & El & 55.90 & 49.50 \\
\hline$S$ & $F$ & & 23.00 \\
\hline
\end{tabular}

3.1.3 Viscosity in the Presence of Biocides

The viscosity of Pfizer's Flocon 1035 (polysaccharide Gl) at various concentrations of biocides was measured at varying shear rates. The results, plotted in Figures 15 through 17, show that viscosity tends to increase with increasing concentration of biocide, although there is no consistent pattern to the curves. Cross-linking of the polysaccharide molecules probably contributes to the viscosity increases. The cross-linking effect appears most noticeably with formaldehyde.

\subsection{Rheologic and Retentive Behavior in Cores \\ Core-flooding tests were performed to determine the resistance factors ( $R F)$, residual resistance factors (RRF),}




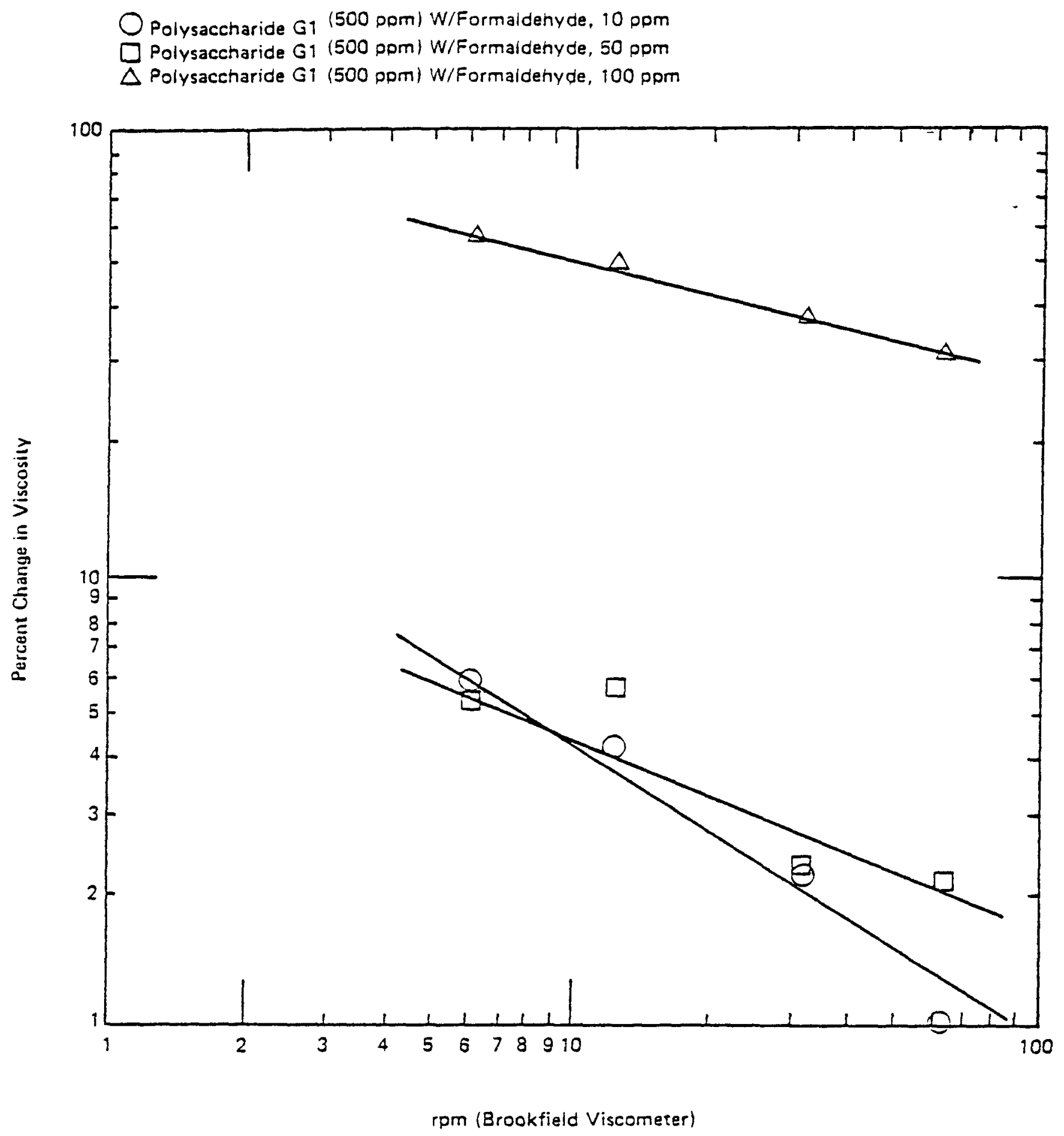

Figure 15. Percent change in viscosity as a function of rpm for polysaccharide $G 1$ with formaldehyde. 


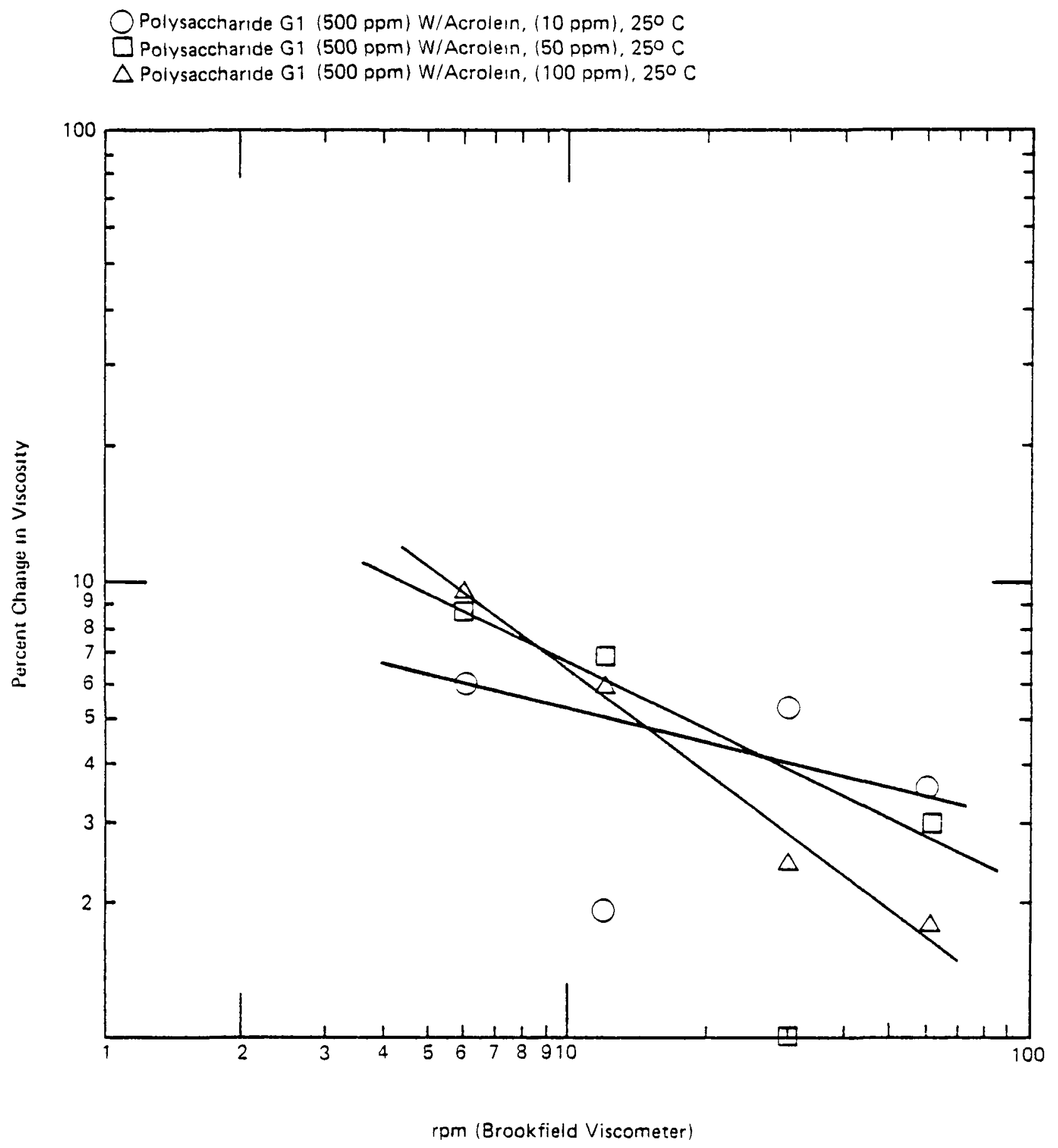

Figure 16. Percent change in viscosity as a function of rpm for polysaccharide $G 1$ with acrolein. 


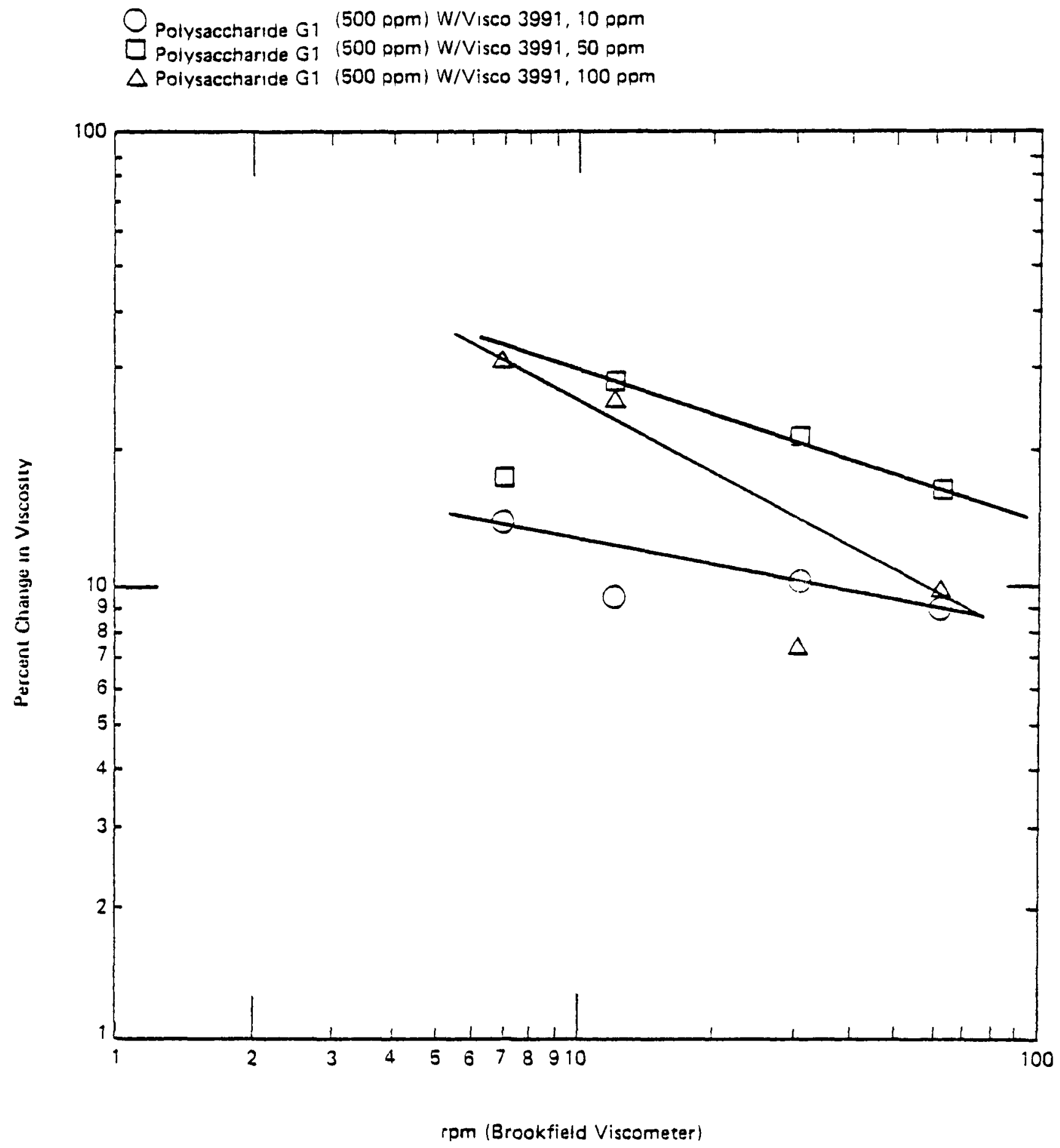

Figure 17. Percent change in viscosity as a function of rpm ior polysaccharide $G 1$ with Visco 3991 
and retention rates of candidate polymers. Since core flooding experiments are lengthy and costly, polymers $E, B$ and G2 were initially selected for further testing on the basis of their compatibilities with river and formation waters. Flow tests on polymers $C$ and $D$ were done at the expense of their manufacturers. Table 12 summarizes the rheologic behavior measured in tests 1 through 12 . Table 13 summarizes the retentive behavior measured in these tests.

\subsubsection{Core Flooding Methodology}

The polymer flow tests numbered $1,4,5,9,10$, and 11 in Table 12 were carried out at Core Laboratories in Dallas, Texas. The other flow tests were carried out by polymer manufacturers. In the Core Labs tests, core samples were prepared by first extracting the residual oil and water using solvents. The solvent-cleaned cores were then placed under the $80 / 20$ brine in a desiccator. The desiccator was then evacuated to $30-50 \mathrm{~mm} \mathrm{Hg}$ at which pressure there was no apparent release of gas bubbles from the core or from the liquid surface. The pore volumes of the cores tested were between $13 \mathrm{cc}$ and $.15 \mathrm{cc}$. A difference of up to 40 percent was measured between the permeabilities to air and liquid, suggesting that in some cases these procedures may not have saturated the core samples completely. Subsequent tests in ERCO's EOR Laboratory evacuated the core before introducing liquid allowing more complete saturation.

Polymer solutions of $I$ weight percent in river water were prepared according to each manufacturer's suggested mixing procedure. Each solution was then diluted to the requisite concentration in an $80 / 20 \mathrm{mix}$ of synthetic river and formation waters. A spot check of the formation water at a recent visit to Core Laboratories indicated that its $\mathrm{pH}$ was 7.8 , a high value compared to 6.8 as listed in Table 9 . - The high pH of the formation water could have caused some of the injectivity problems experienced with biopolymer $\mathrm{G} 2$. Each diluted polymer was filtered in a Seals No. 10 Candle Filter, a microporous porcelain filter.

The flow experiments were conducted in the vertical upflow mode with the reservoir rock held in a Hassler sleeve. A confining pressure of 300 psig was applied radially on the core and the back pressure was held to 40 psig. The pressure drop between the inlet and outlet 1 ines of the core was recorded continuously during the run. Polymer concentrations in the effluent stream were measured by precipitation of the polymer in the $1.0 \mathrm{cc}$ to $1.5 \mathrm{cc}$ samples and turbidimetric evaluation of the precipitated 
TABLE 12

RHEOLOGICAL BEHAVIOR OF POLYMERS IN RESERVOIR CORES AT $95^{\circ} \mathrm{F}$ and ${ }^{2} 2.0^{\prime} / \mathrm{DAY}$

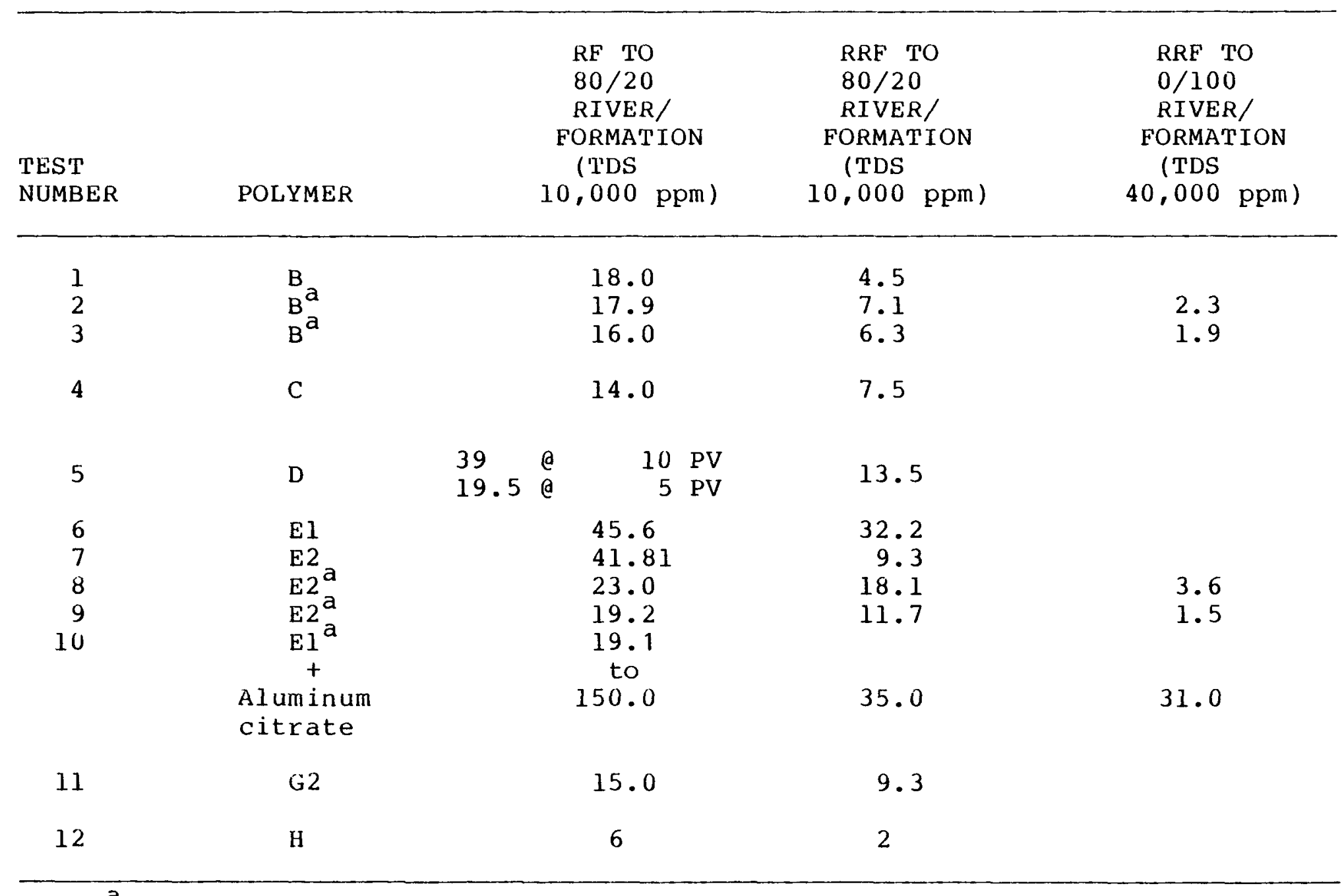

${ }^{a}$ Carried out with residual oil (courtesy of CORT). 
TABLE 13

RETENTIVE BEHAVIOR OF POLYMERS IN RESERVOIR CORES AT $95^{\circ} \mathrm{F}$ and $\sim 2.0^{\prime} / \mathrm{DAY}$

WITH AN $80 / 20$ MIX OF RIVER AND FORMATION WATER

\begin{tabular}{|c|c|c|c|c|}
\hline & & & POLYMER & RETENTION \\
\hline $\begin{array}{l}\text { TEST } \\
\text { NUMBERS }\end{array}$ & POLYMER & $\mathrm{LB} / \mathrm{ACRE}-\mathrm{FT}$ & $\mu g / g$ ROCK & $\begin{array}{l}\text { FRACTIONAL } \\
\text { RETENTION } \\
\text { OF POLYMER } \\
\text { INJECTED }\end{array}$ \\
\hline 1 & $B$ & 309 & 55.1 & 0.131 \\
\hline 2 & $\mathrm{~B}^{\mathrm{a}}$ & 385 & 68.6 & 0.163 \\
\hline 4 & $\mathrm{C}$ & 236 & 40.5 & 0.094 \\
\hline 6 & El & 299 & 53.0 & 0.106 \\
\hline 7 & $\mathrm{E} 2$ & 227 & 39.8 & 0.084 \\
\hline 8,9 & E2a & 330 & 58.9 & 0.140 \\
\hline 11 & $\mathrm{G} 2$ & 321 & 57.3 & 0.136 \\
\hline
\end{tabular}


amounts. The polymer retentions were evaluated from the area under the retention curve and the elution-desorption curve. These values are then the "irreversible" retentive losses of polymer recorded in Table 13.

\subsubsection{Results of Core Flooding Experiments}

The transient $R F$ and effluent concentrations of polymers and tracers are plotted in Figures 18 through 28 . In Figure 18 the RRF of polymer El dropped to 3.7 after the upstream end of the sample was trimmed. This may have been indicative of sand-face plugging but not filter-cake buildup since the transient RF curve flattens out at large pore-volume throughput. Inlet and outlet end effects could be responsible for the extremely high resistance factors; the transient pressure drops were measured across the inlet and outlet lines. Sand-face plugging is a probable cause for the high value of polymer retention. The breakthrough concentration in Figure 18 never reaches the inlet concentration. This core flooding experiment was repeated at the supplier's expense with a lower molecular weight polymer, E2. The RRF was reduced to 9.0 and the retention for this run was 227 lb/acre-ft. The transient RF and concentration curves of polymer E2 are illustrated in Figure 19.

The RRF of polymer $B$ in Figure 20 does not indicate. plugging, although the transient RF curve shows a monotonic increase with pore-volume throughput. The slight upward trend in the transient RF suggests some plugging behavior at high values of pore-volume throughput.

The transient RF and concentration curves of polysaccharide $G 2$ are illustrated in Figure 21 . The transient RF curve reflects some plugging behavior but not to the degree indicated by the high retention rate (321 lb/acre-ft). The RRF of 9.3 (very high for a polysaccharide) reflects this polymer retention. Note that the effluent polymer concentration appears stabilized at 90 percent of the injected concentration. This deviation from 100 percent could have resulted from inaccurate measurements of the polymer concentration, inaccurate pore volumes, or significant dead volume since 1/8-inch Swagelock connectors were used in the flow experiments. The large retention could have resulted from failure to filter the water properly before dilution, from reversible complexing with such divalent ions as $\mathrm{Ca}^{++}$or $\mathrm{Mg}^{++}$, or from the high $\mathrm{pH}^{3}$

\section{${ }^{3}$ McCaffery, F.G. and Edilison, F.L. (1977), An}

Investigation of the gelation tendencies of Pfizer's Biopolymer 1935, Petroleum Recovery Institute, Research Note RN-5 (January 1, 1977). 


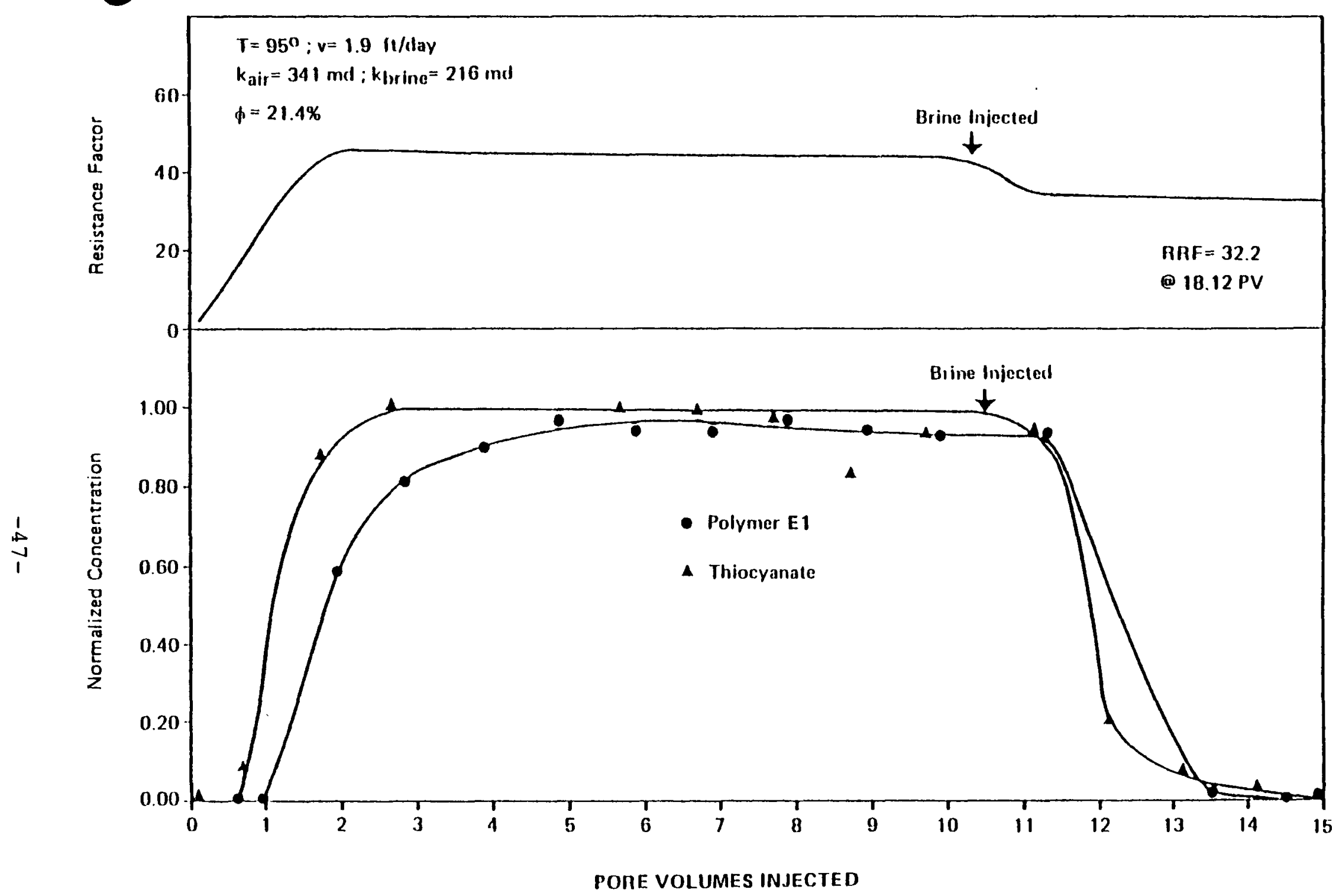

Figure 18. Resistance factor and concentrations of Polymer $E$ in reservoir cores at $95^{\circ} \mathrm{F}$. 


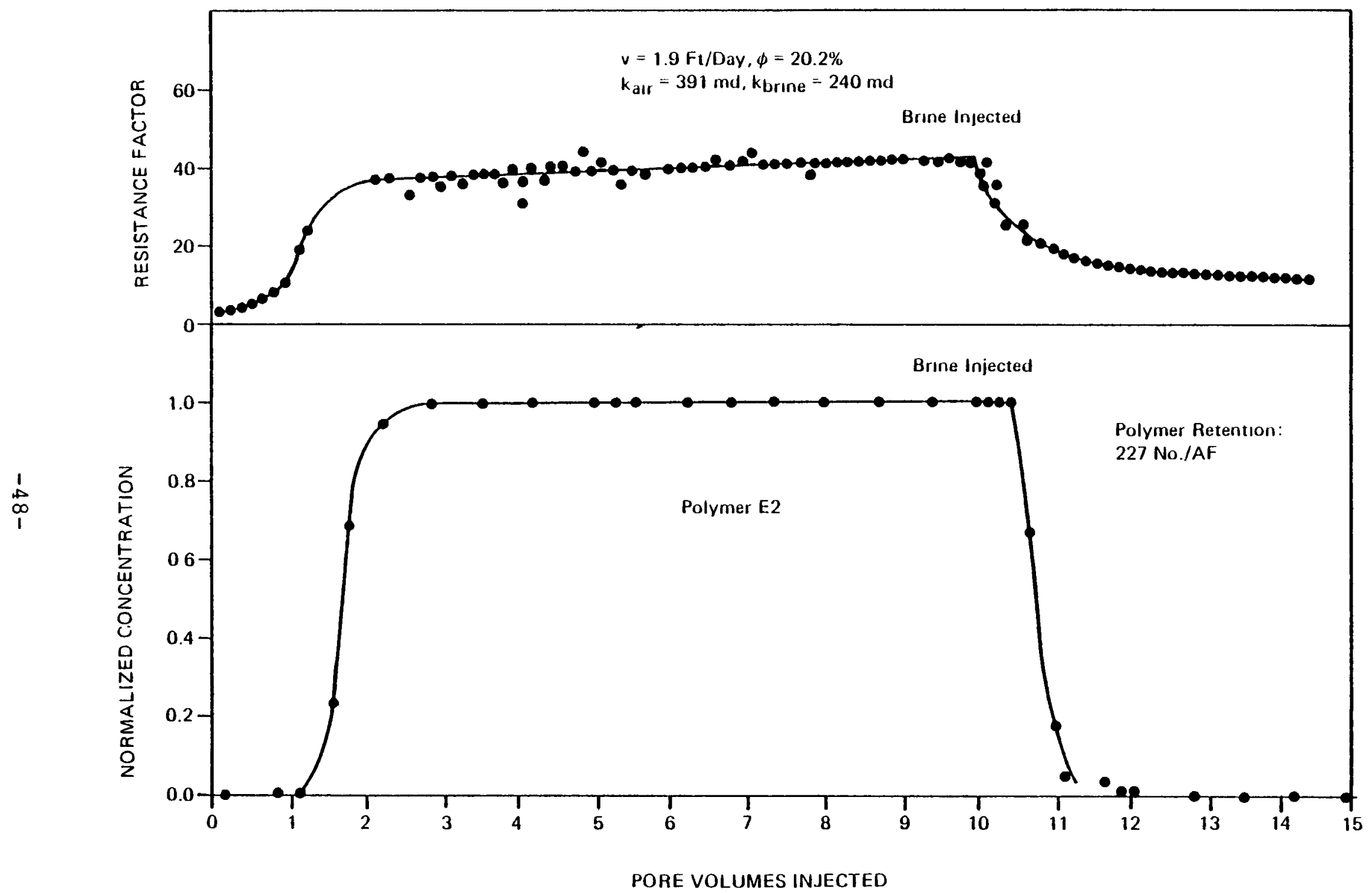

Figure 19. Resistance factors and concentrations of Polymer E2 in reservoir cores at $95^{\circ} \mathrm{F}$. 


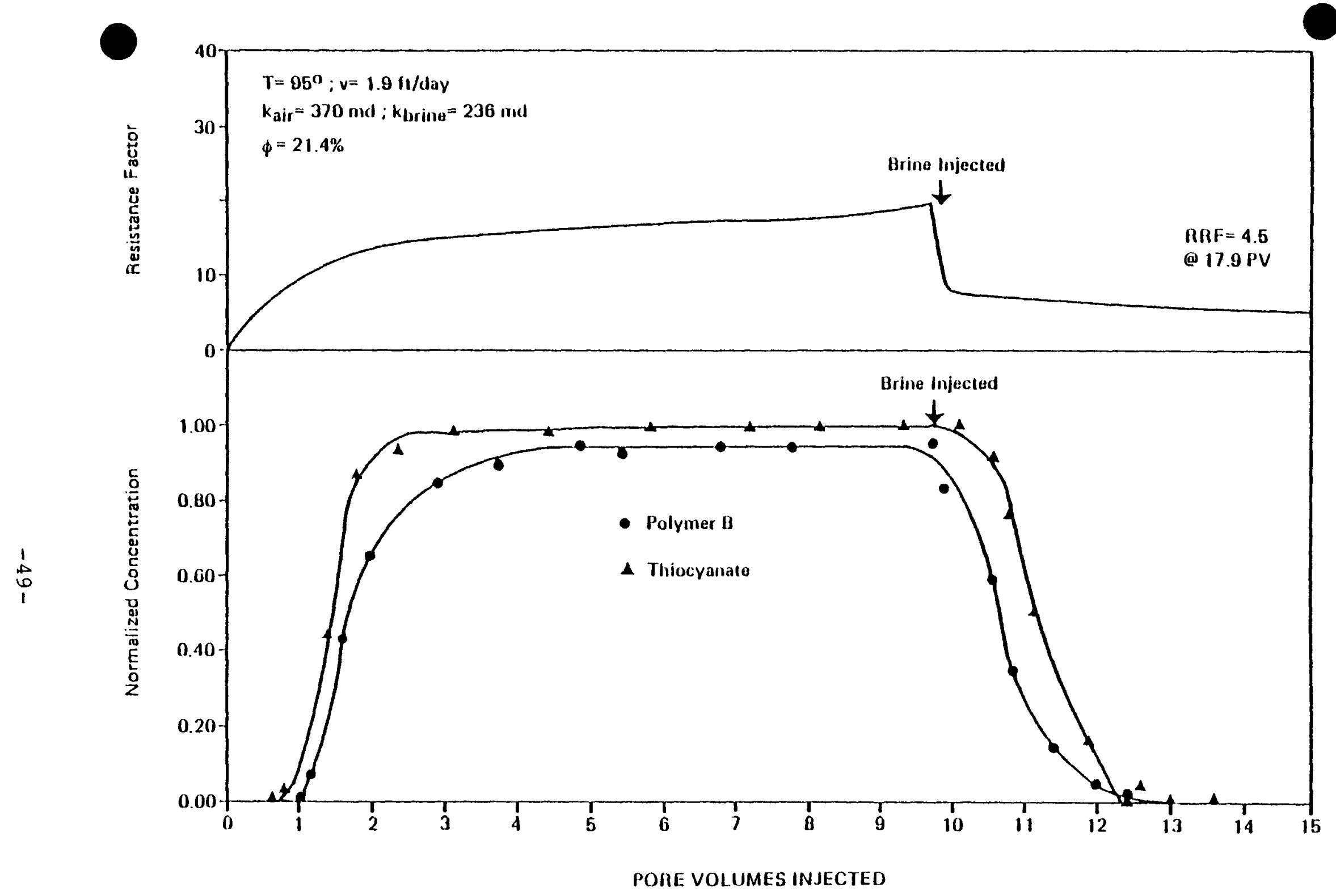

Figure 20. Resistance factor and concentrations of Polymer $\mathrm{B}$ in reservoir cores at $95^{\circ} \mathrm{F}$. 


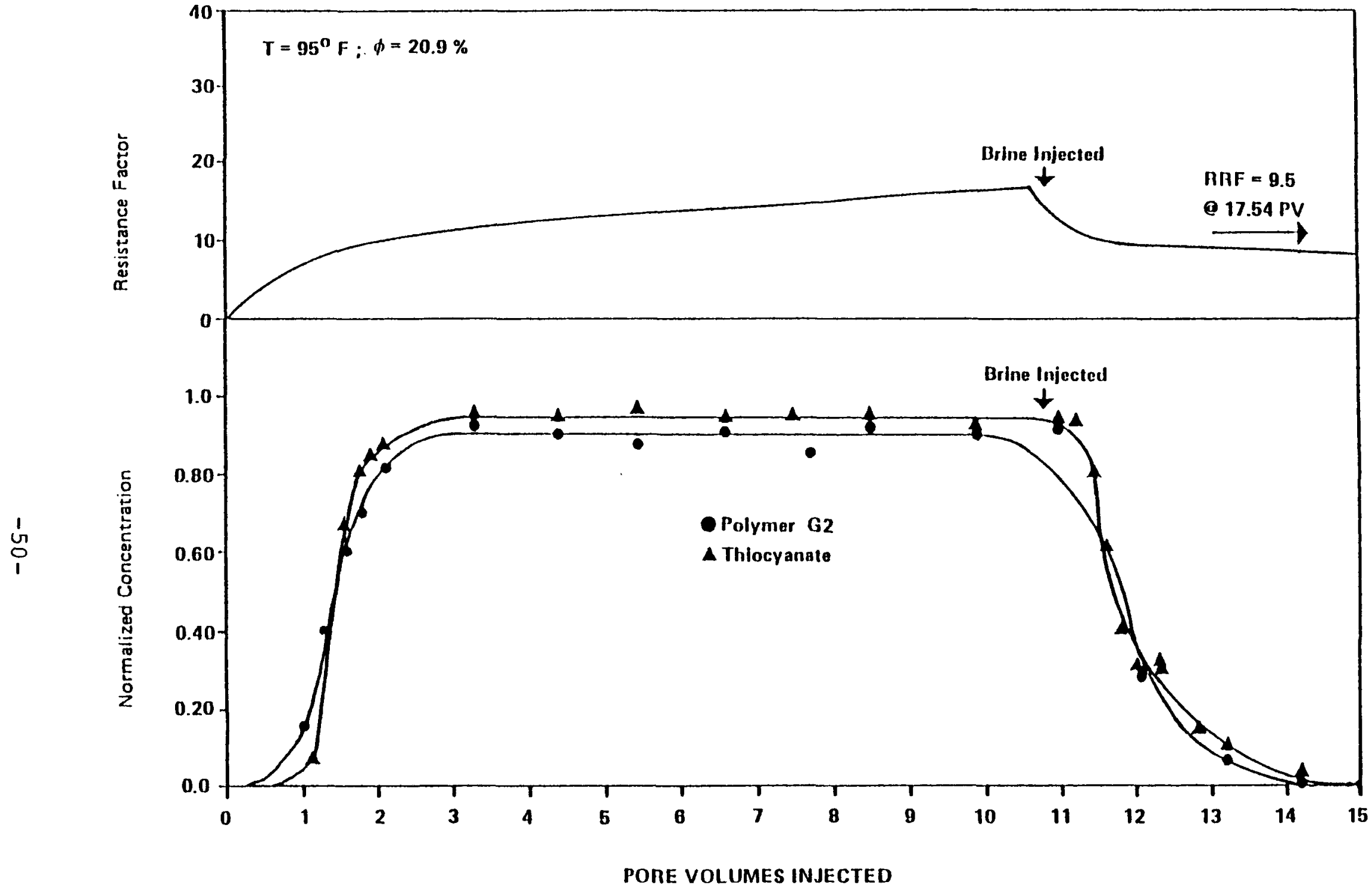

Figure 21. Resistance factor and concentrations of Polymer G2 in reservoir cores at $95^{\circ} \mathrm{F}$. 
Polymer rheology tests on polyacrylamide E2 (Tests 8 and 9, shown in Figures $3-22$ and $3-23$, respectively) indicate some difference between CORT's test results and the results from Core Laboratories. Although the RF from the manufacturer's test, Test 8 , is approximately half that of Test 7 , the retention of Test 8 is less than the retention of Test 6 . These discrepancies are also observed with the RF and RRF to 80/20 mix between Tests 7 and 8 and between Tests 1 and 2 . CORT measured differential pressure drops across a slowly rotating core and measured retention by recirculating the injected solution until the concentration of the polymer injected was equal to the concentration in the effluent stream. The procedures used to mitigate capillary end effects, gravity segregation, and nonequilibrium adsorption in CORT's experiments could be reasons for the differences between their results and the results from Core Laboratories.

Test 10, illustrated in Figure 24, was carried out with polyacrylamide EI and an aluminum citrate mixture. The high RF of 145 indicates effective permeability reduction of the aqueous phase in the core. The RRF of 35 to the $80 / 20$ mix indicates that mobility control would be very effective during the fresh-water-drive stage of the improved waterflood. This residual permeability reduction appears irreversible since the RRF to the 100 percent brine is approximately the same as that of the $80 / 20 \mathrm{mix}$ of fresh water and brine. This high RRF to brine indicates that mobility control by a polyacrylamide-aluminum citrate treatment would be effective during the fresh-water and subsequent brine floods which follow the polyacrylamide slug.

The transient $\mathrm{RF}$ and concentration profiles of polymer C2 are illustrated in Figure 25. The increase of the RF curve suggests that some plugging of the reservoir occurs. A previous test at Cyanamid's expense with a lower molecular weight polymer ( $\mathrm{Cl}$ ) showed little active or residual resistance effects; Cyanamid did not release the details of this test.

The transient RF curve in Figure 26 indicates that filter cake plugging of the reservoir core was significant for polymer $D$. The injectivity problems could have resulted from incompatibility of this polyacrylamide with the reservoir brines. This possible incompatibility is inferred from the electrochemical degradation factor of 17.8 listed in Table 10 .

The polyacrylamide and polysaccharide which performed best in the compatibility studies and core experiments were tested for rheological and retentive behavior in cores in a 100 percent brine environment. These severe tests reflect 


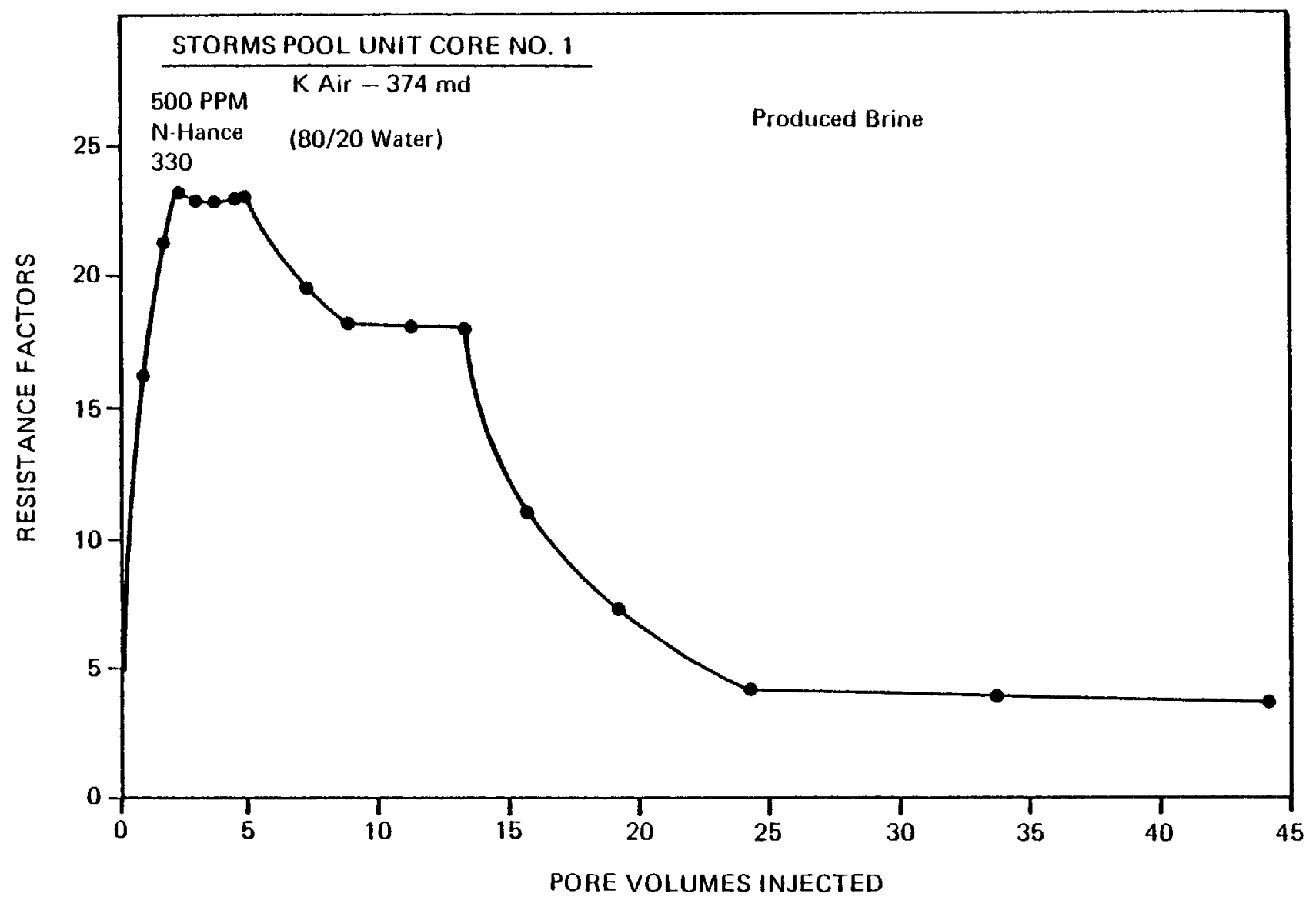

Figure 22. Resistance factor of polymer E2 in reservoir cores at $95^{\circ} \mathrm{F}$ (Courtesy of CORT). 


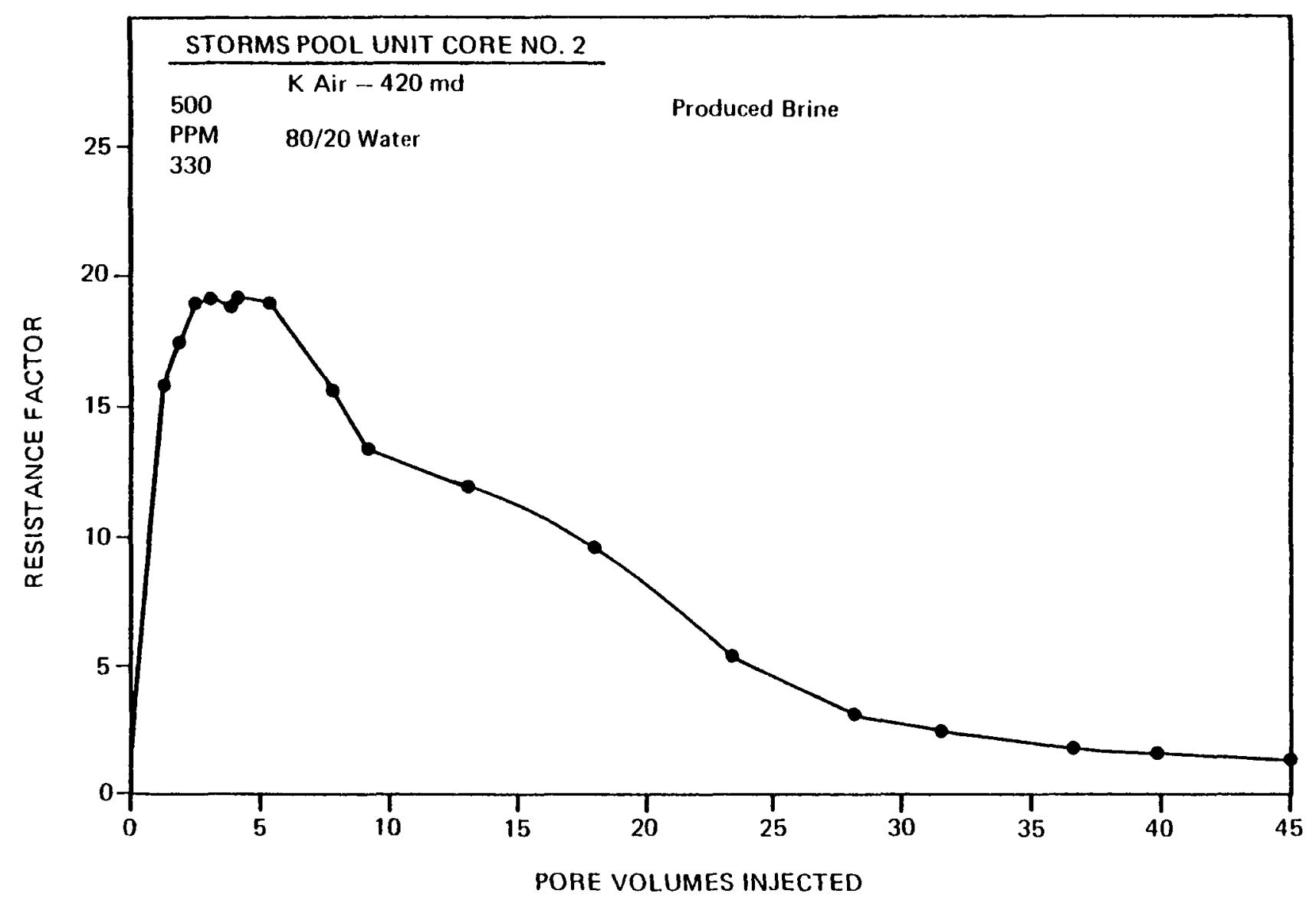

Figure 23. Resistance factor of polymer $\mathrm{E} 2$ in reservoir cores at $95^{\circ} \mathrm{F}$ (Courtesy of CORT). 


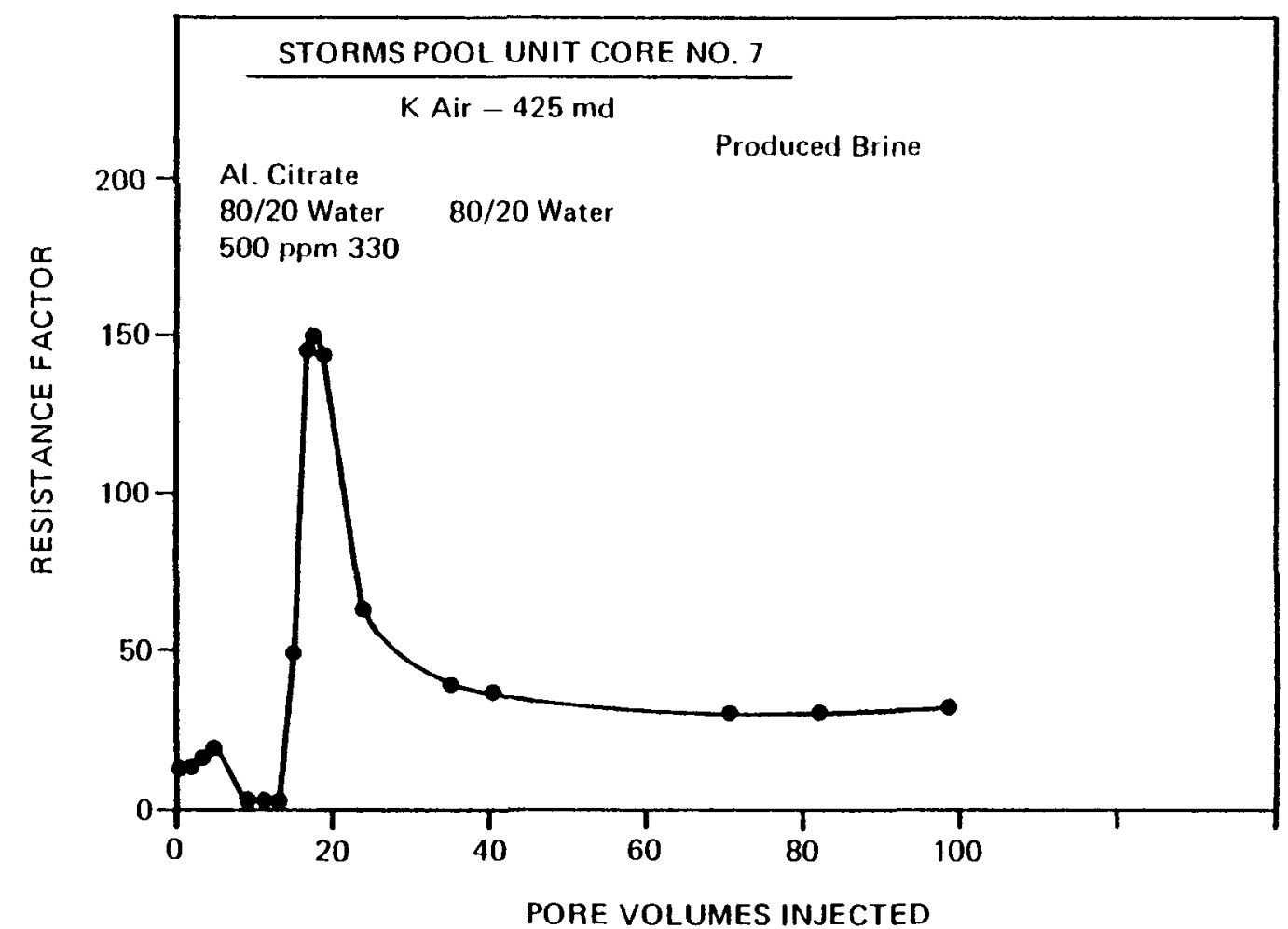

Figure 24. Resistance factors of polymer $E 1$ with aluminum citrate in reservoir cores at $95^{\circ} \mathrm{F}$ (Courtesy of CORT). 


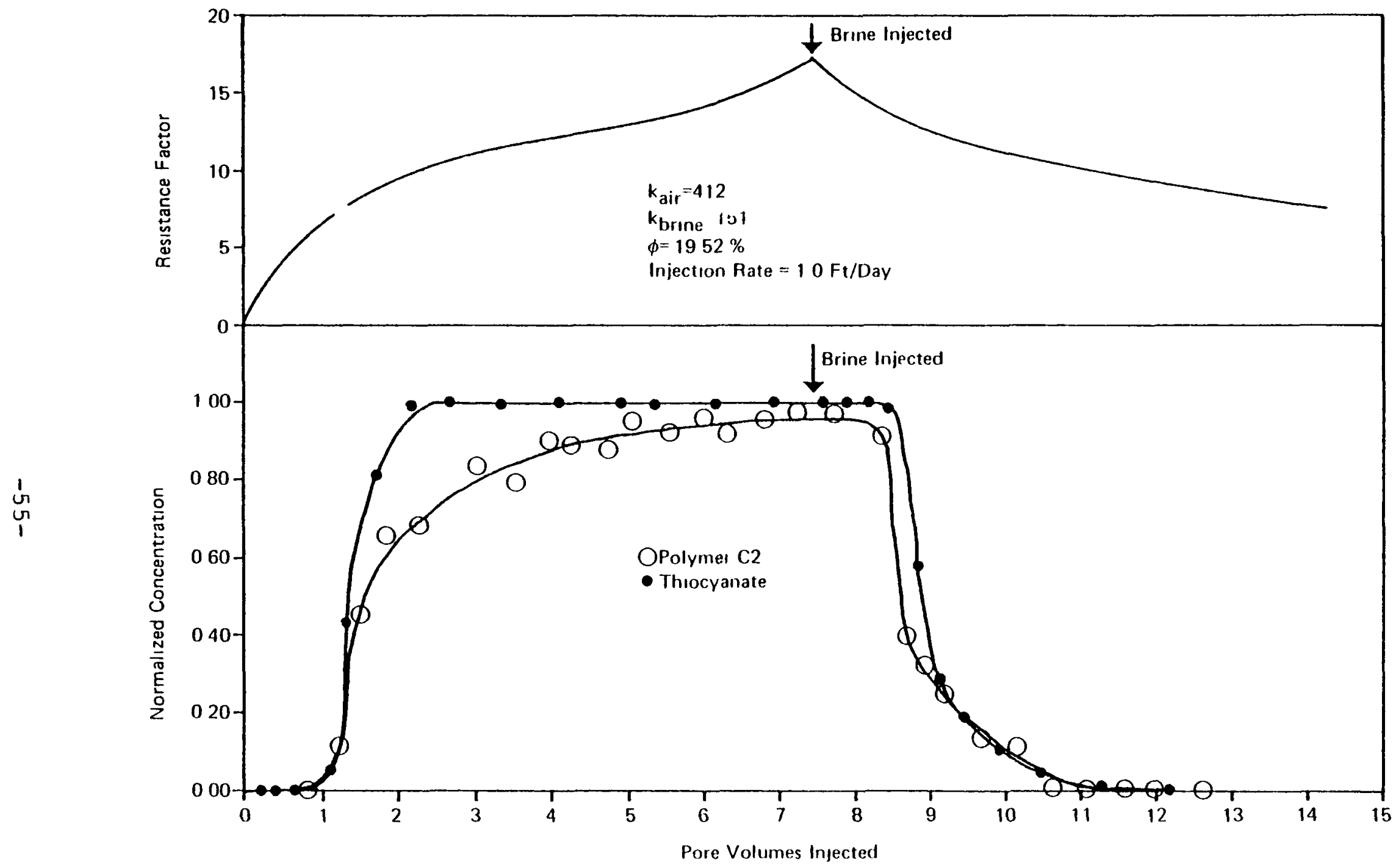

Figure 25. Resistance factor and concentration profile of polymer $\mathrm{C} 2$ in $80 / 20$ mix with thiocyanate. 


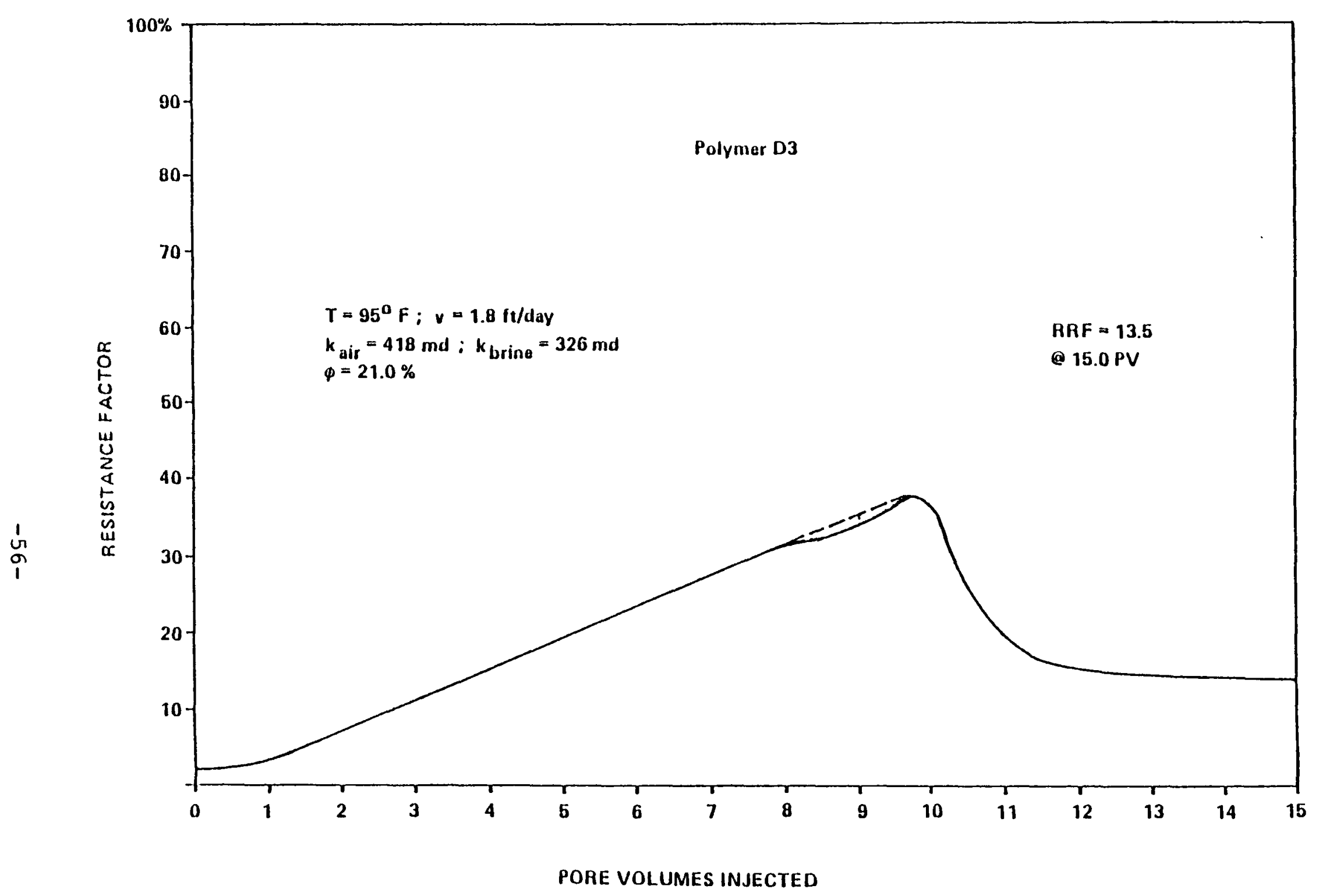

Figure 26. Resistance factor of Polymer $D$ in reservoir cores at $95^{\circ} \mathrm{F}$. 
the interaction of the polymers with brines of unswept regions in the reservoir. The polymers were dissolved in distilled water and then mixed with 100 percent brine to the desired concentration of $500 \mathrm{ppm}$. The dilution was such that the brine concentration was greater than 99 percent. The results of the compatibility studies for these polymers are 1 isted in Table 14 .

The rheological and retentive behavior of these polymers is graphed in Figures 27 and 28. As indicated in the transient RF curve in Figure 28, the injectivity of polyacrylamide $\mathrm{G} 2$ is not severely impaired by the presence of high salinity brines. The transient RF curve of polyacrylamide E2, Figure 28, implies that a significant amount of sand-face plugging occurs in the high salinity environment. The $R F, R R F$ and retention of these polymers in the $80 / 20 \mathrm{mix}$ and 100 percent formation water are tabulated in Table 15. The RF and RRF of polyacrylamide E2 in 100 percent river water (a courtesy of CORT) is also listed in Table 15. The RF and RRF of the polyacrylamide is not as affected by high salinity as the viscosity. The RF and RRF of the polysaccharide is much more affected by the high salinity environment than the viscosity.

\subsubsection{Further Testing of Pfizer's Flocon 1035}

Energy Resources remeasured the rheologic and retentive behaviors of polysaccharide Gl (Pfizer's Flocon 1035) after

TABLE 14

ELECTROCHEMICAL DEGRADATION OF 500 pPm ACTIVE POLYMER AT A SHEAR RATE OF $7.3 \mathrm{SEC}^{-1}$ and $95^{\circ} \mathrm{F}$

\begin{tabular}{|c|c|c|c|c|c|}
\hline POLYMER & $\begin{array}{l}\text { VISCOS- } \\
\text { ITY IN } \\
1008 \\
\text { RIVER } \\
\text { WATER } \\
(\mathrm{cp})\end{array}$ & $\begin{array}{l}\text { VISCOSITY } \\
\text { IN } 80 / 20 \\
\text { MIX RIVER/ } \\
\text { FORMATION } \\
\text { WATER (CP) }\end{array}$ & $\begin{array}{l}\text { ELECTRO- } \\
\text { CHEMICAL } \\
\text { DEGRADA- } \\
\text { TION } \\
\text { FACTOR }\end{array}$ & $\begin{array}{l}\text { VISCOSITY } \\
\text { IN } 100 \% \\
\text { WATER } \\
\text { (cp) }\end{array}$ & $\begin{array}{l}\text { ELECTRO- } \\
\text { CHEMICAL } \\
\text { DEGRADA- } \\
\text { TION } \\
\text { EACTOR }\end{array}$ \\
\hline $\begin{array}{l}\text { Polyacryl- } \\
\text { amide E2 }\end{array}$ & 42.4 & 3.8 & 11.2 & 1.3 & 32.6 \\
\hline $\begin{array}{l}\text { Polysac- } \\
\text { charide G2 }\end{array}$ & 13.0 & 12.5 & 1.04 & 13.5 & $(0.96)$ \\
\hline
\end{tabular}




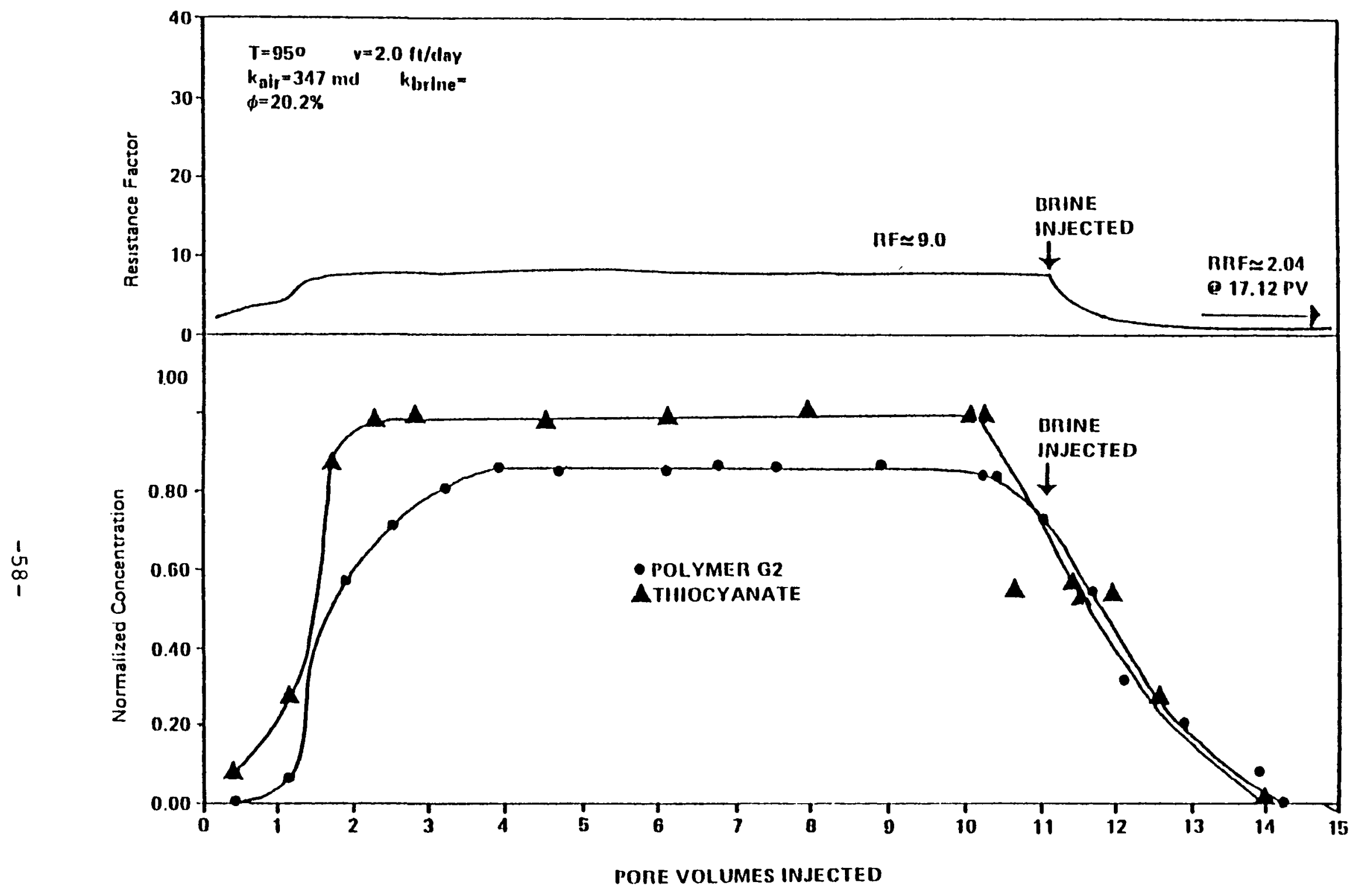

Figure 27. Resistance factor and concentrations of Polymer G2 in reservoir core $@ 95^{\circ} \mathrm{F}$ with $100 \%$ formation brine in the connate water and in the injected solution. 


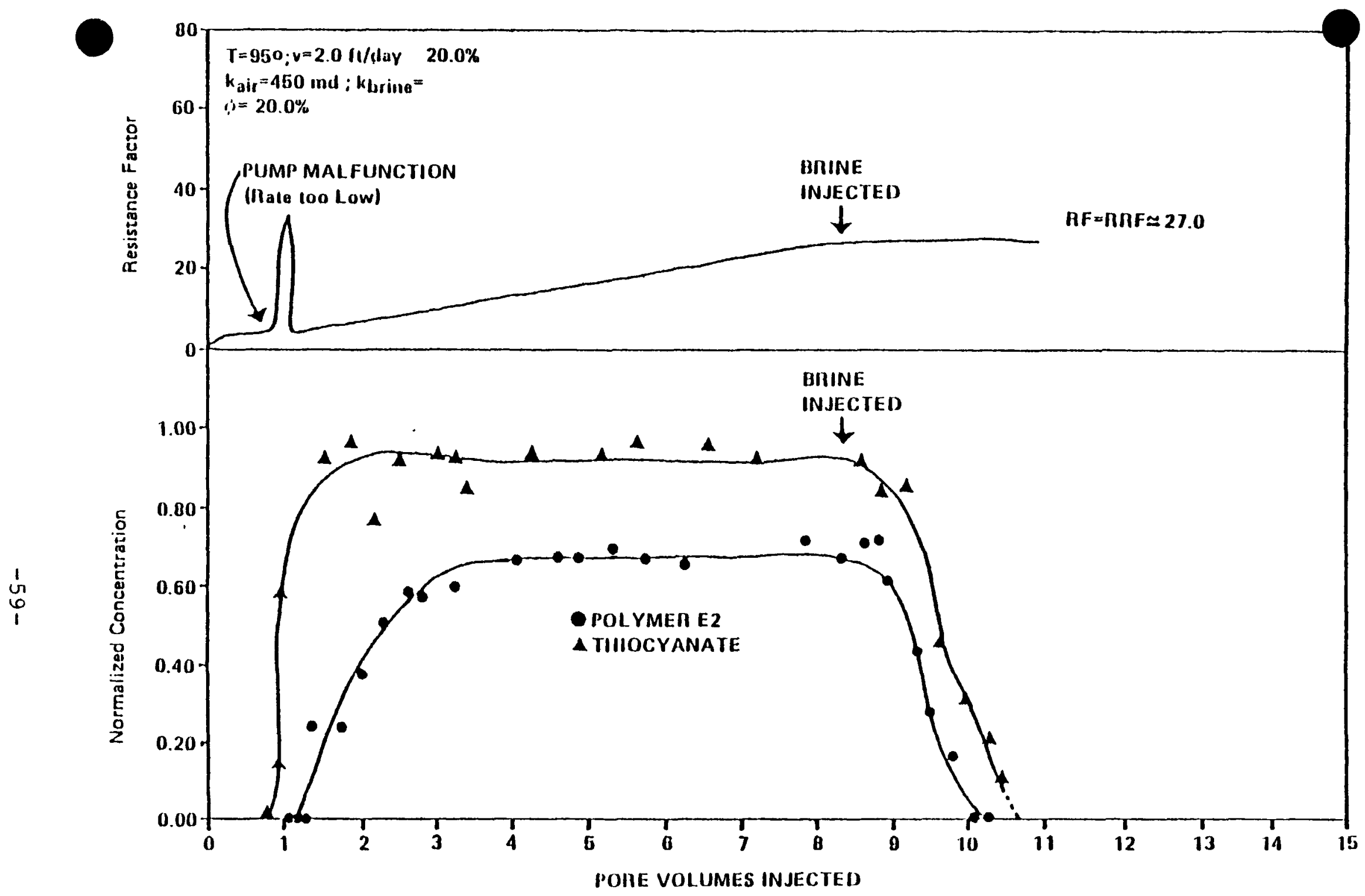

Figure 28. Resistance factors and concentrations of Polymer E2 in reservoir core @95 ${ }^{\circ} \mathrm{F}$ with $100 \%$ formation brine in the connate water and in the injected solution. 
TABLE 15

RHEOLOGICAL AND RETENTIVE BEHAVIOR OF A POLYSACCHARIDE AND A POLYACRYLAMIDE IN RESERVOIR CORE AT $95^{\circ}$ F AND $\sim 2.0$ FT/DAY

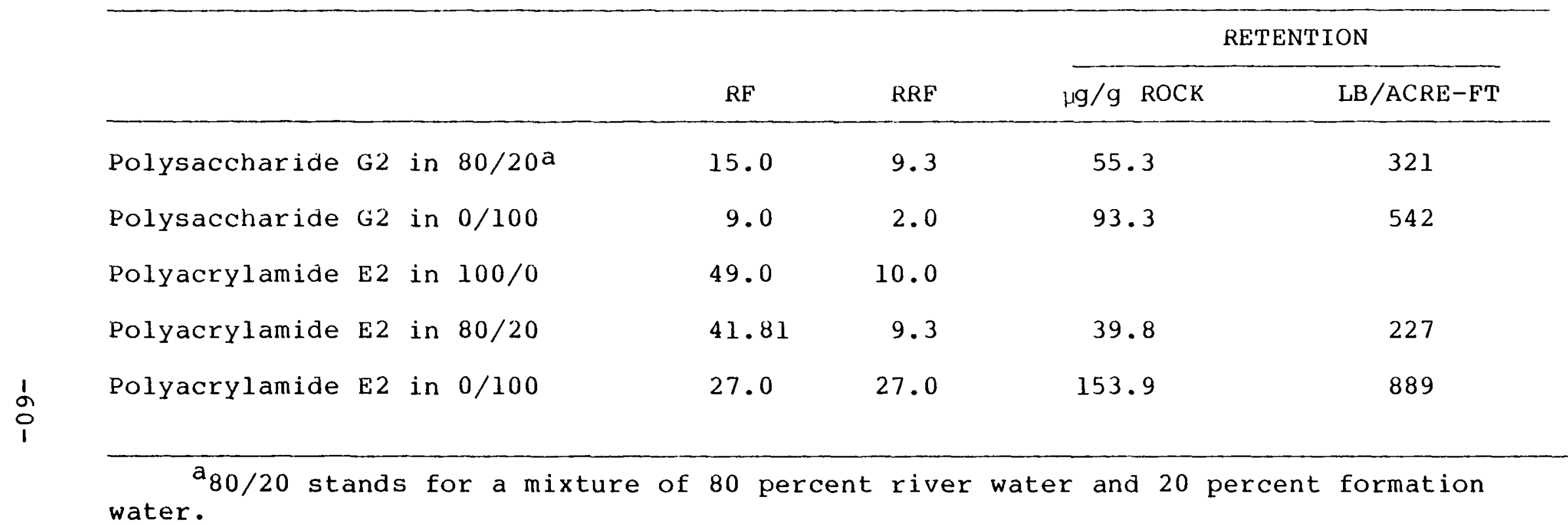


the dilute polymeric solutions were filtered. Figures 29 through 36 show the breakthrough and transient RF curves for these tests, conducted at $75 \pm 2^{\circ} \mathrm{F}$ in restored-state reservoir cores saturated with formation brine. The measurements were made with $500 \mathrm{ppm}$ of active polymer dissolved in filtered and unfiltered river water and in filtered and unfiltered formation brine; solutions were filtered through a 10-micron ceramic filter under a pressure head of between 1 and 4 psig. The retentions are summarized in Table 16 . These retentions compare with previously measured retentions of $55.3 \mathrm{\mu g} / \mathrm{g}$ rock and $93.3 \mathrm{\mu g} / \mathrm{g}$ rock for $500 \mathrm{ppm}$ polysaccharide $\mathrm{G} 2$ in the filtered $80 / 20 \mathrm{mix}$ and in filtered formation water at $95^{\circ} \pm 2^{\circ} \mathrm{F}$. The differences in retention between the filtered and unfiltered solutions indicate that a significant portion of the retention results from mechanical entrapment of microgels which are formed in the presence of divalent cations such as $\mathrm{Mg}++$ and Ca+t. Early breakthrough of the polysaccharide (at roughly 0.3 PV throughput) occurs because of species dispersion which is accentuated by the short length of the reservoir cores. The breakthrough concentration profiles were measured by a phenol/ sulphuric acid assay of the effluent stream; the calibration curve for the spectrophotometer and cell path used is plotted in Figure 37.

TABLE 16

RETENTION RATES OF PHIZER'S FLOCCON 1035 USING FILTERED AND UNF ILTERED MAKEUP WATERS

\section{5 ppm ACTIVE POLYSACCHARIDE}

GI IN :

RETENTION

\begin{tabular}{lcc}
\multicolumn{1}{c}{ GI IN : } & $\mu \mathrm{g} / \mathrm{g}$ ROCK & LB/ACRE-ET \\
\hline River water (filtered) & 16.34 & 95 \\
Formation water (filtered) & 20.70 & 120 \\
River water (unfiltered) & 31.00 & 180 \\
Formation water (unfiltered) & 63.80 & 370 \\
\hline
\end{tabular}




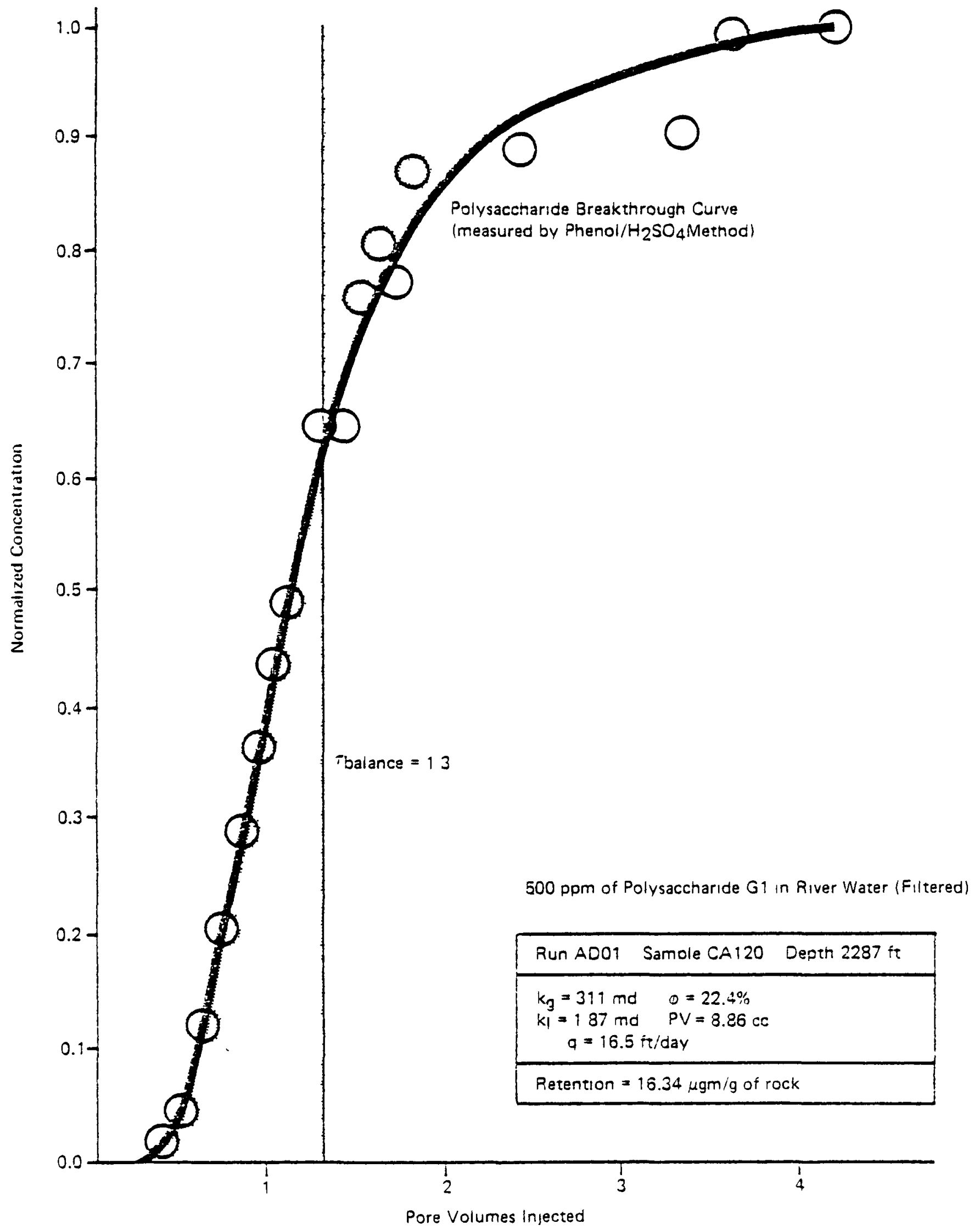

Figure 29. Breakthrough concentration profile of dilute polysaccharide solution from reservoir cores (Waltersburg Formation) at $75 \pm 20 \mathrm{~F}$.

$-62-$ 


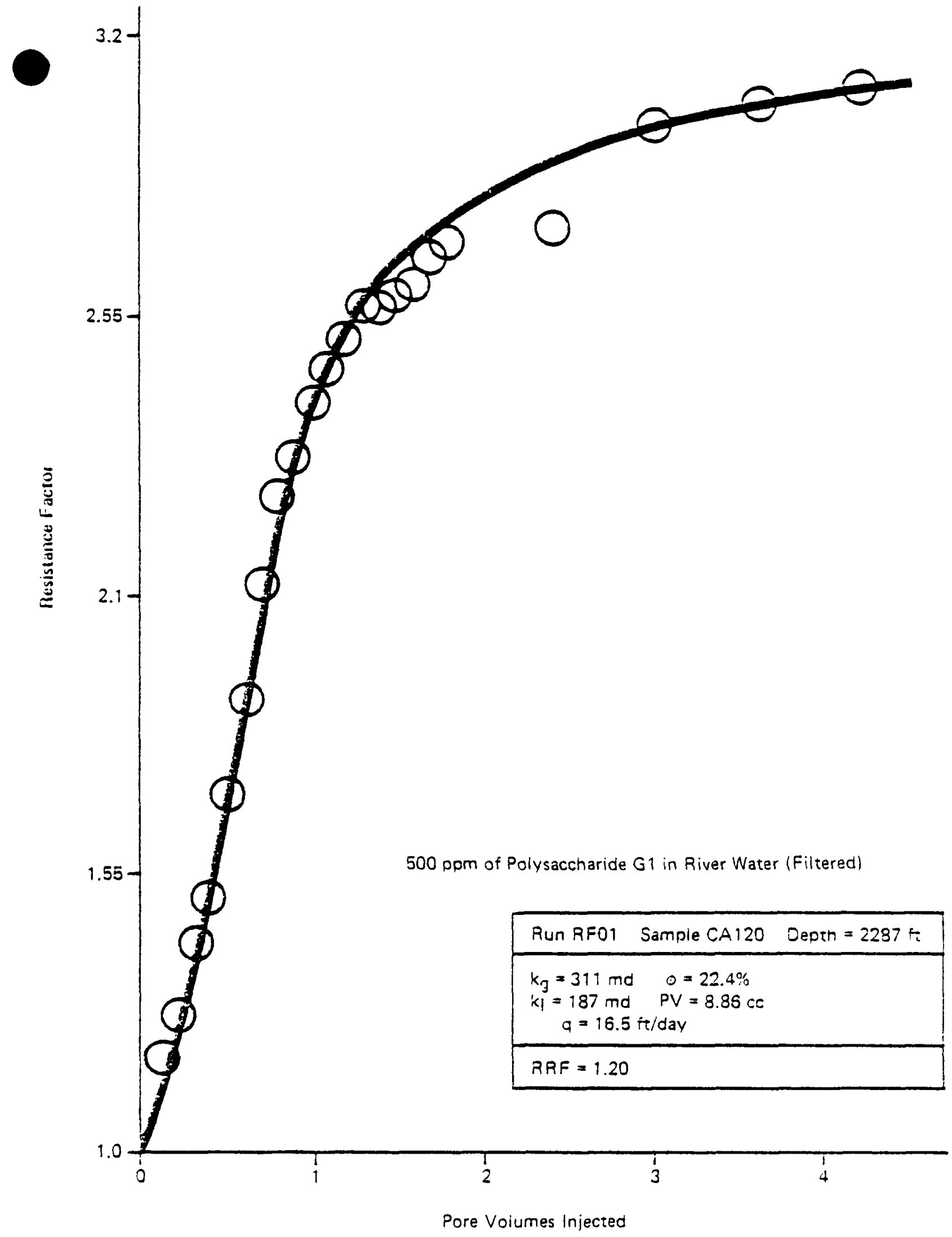

Figure 30. Resistance factor of dilute polysaccharide solution in reservoir cores (Waltersburg Formation) at $75+20 \mathrm{~F}$. 


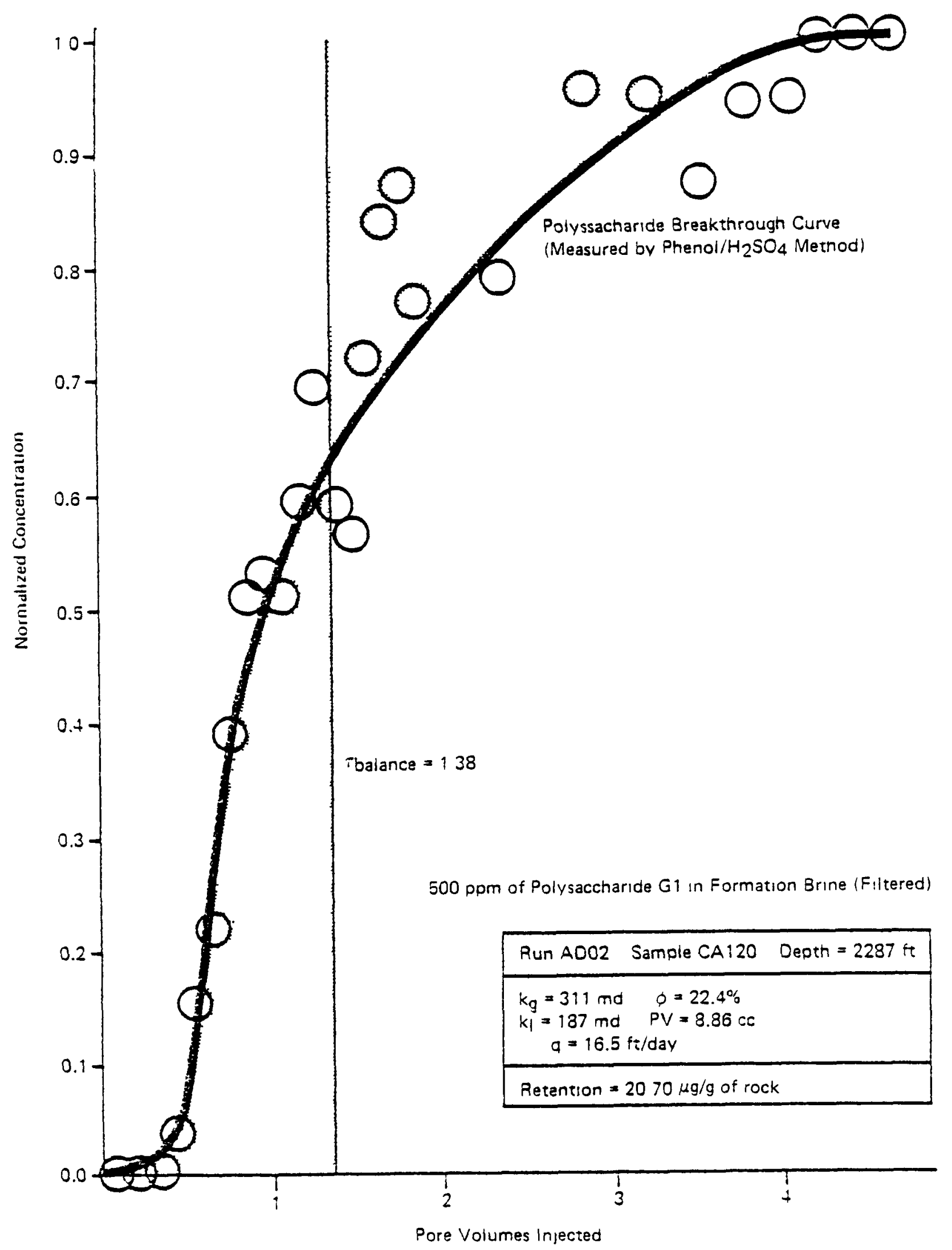

Figure 31. Breakthrough concentration profile of dilute polysaccharide solution from reservoir cores (Waltersburg Formation) at $75 \pm 20 \mathrm{~F}$ 


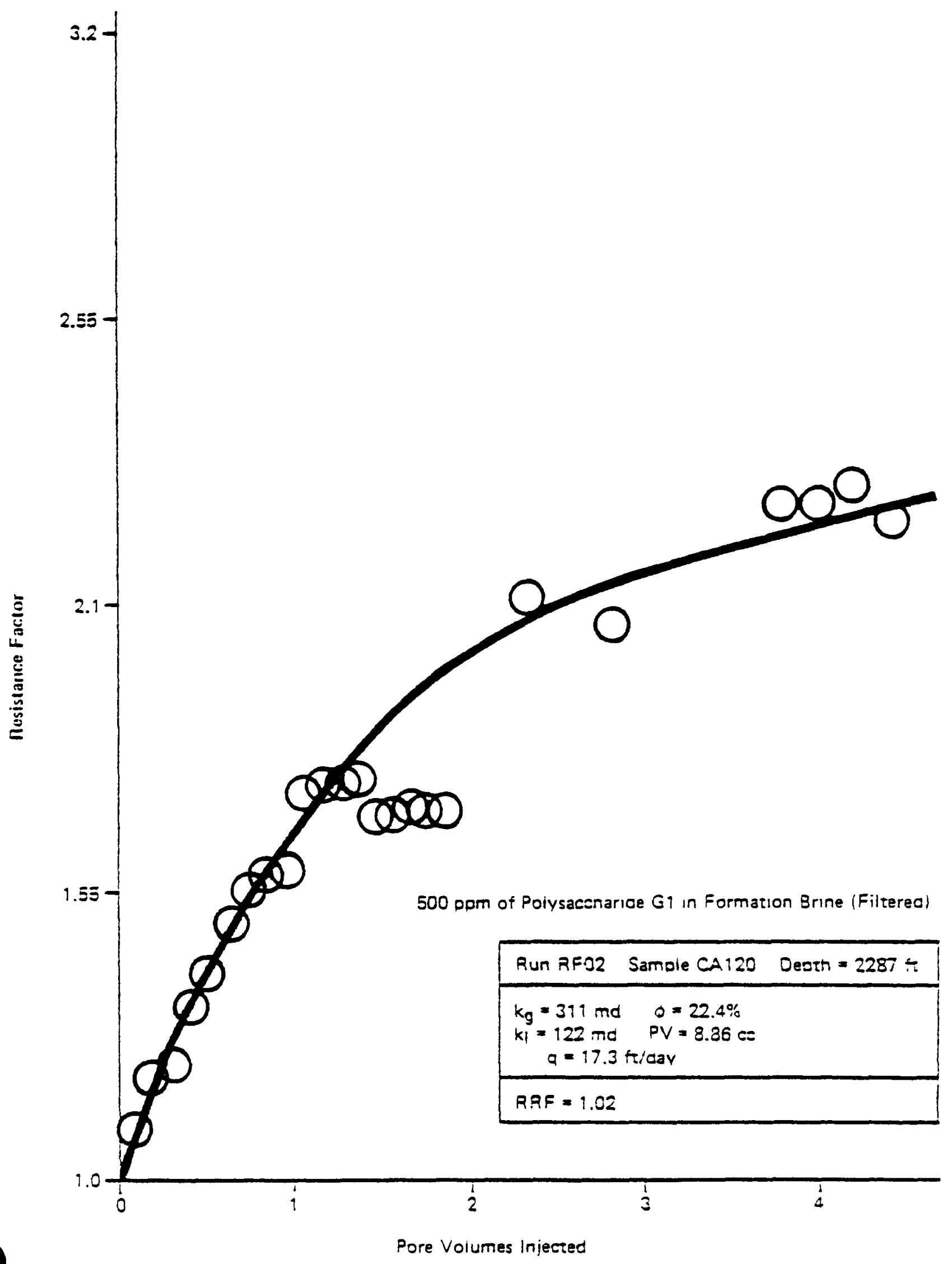

Figure 32. Resistance factor of dilute polysaccharide solution from reservoir cores (Waltersburg Formation) at $75^{+} 2^{\circ} \mathrm{F}$. 


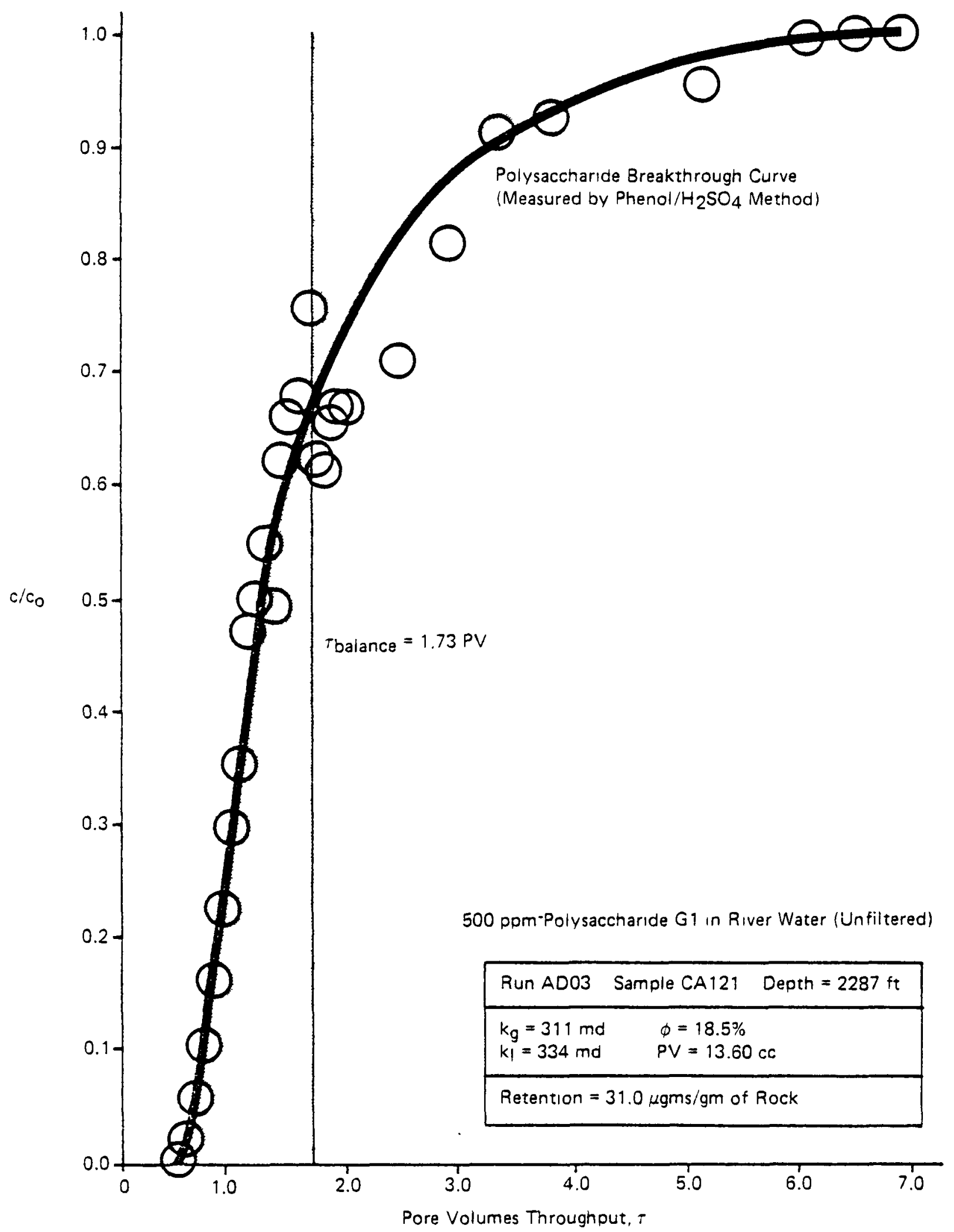

Figure 33. Breakthrough concentration profile of dilute polysaccharide solution from reservoir cores (Waltersburg Formation) at $75 \pm 2$ o F. 


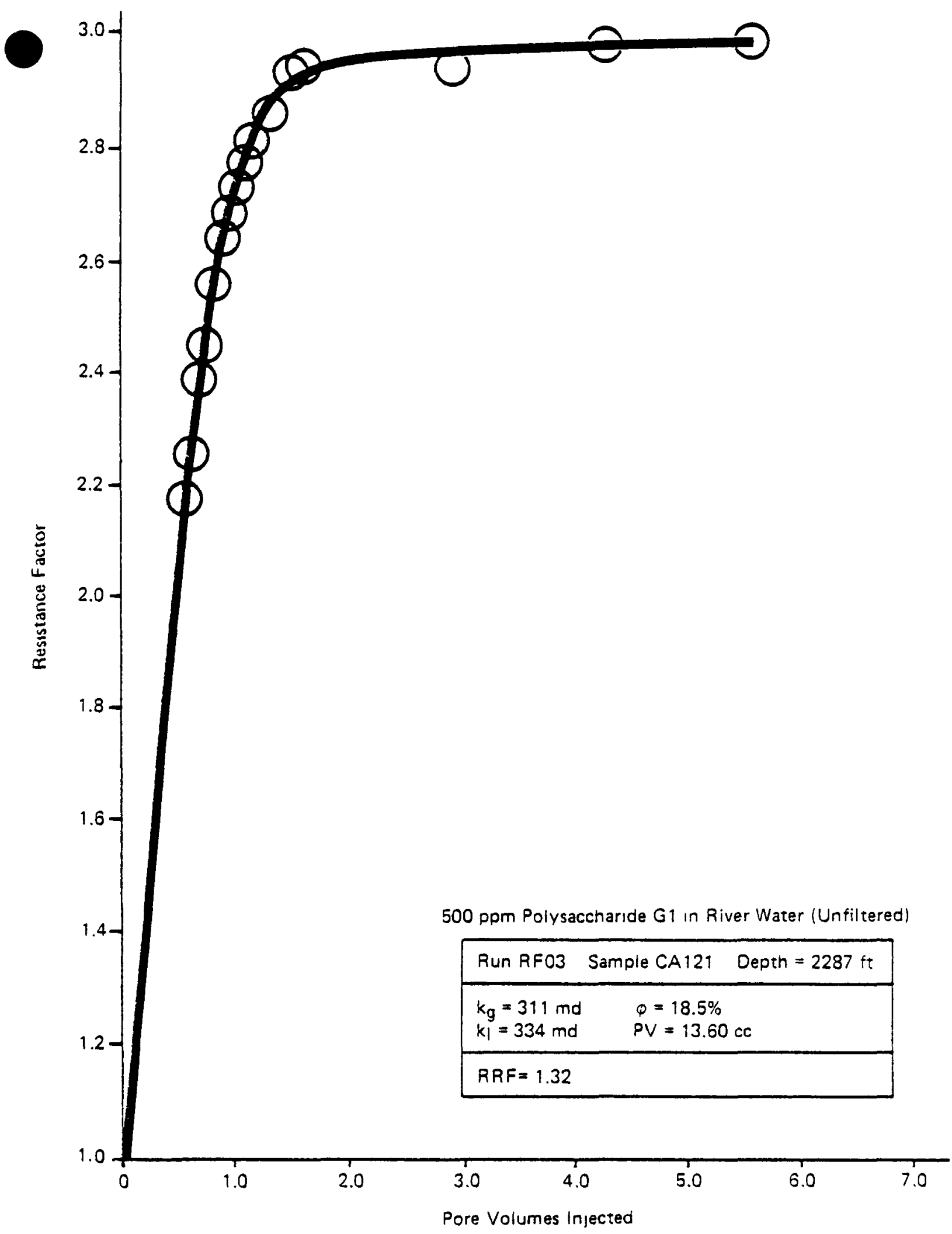

Figure 34. Resistance factor of dilute polysaccharide solution in reservoir cores (Waltersburg Formation) at $75 \pm 20 \mathrm{~F}$. 


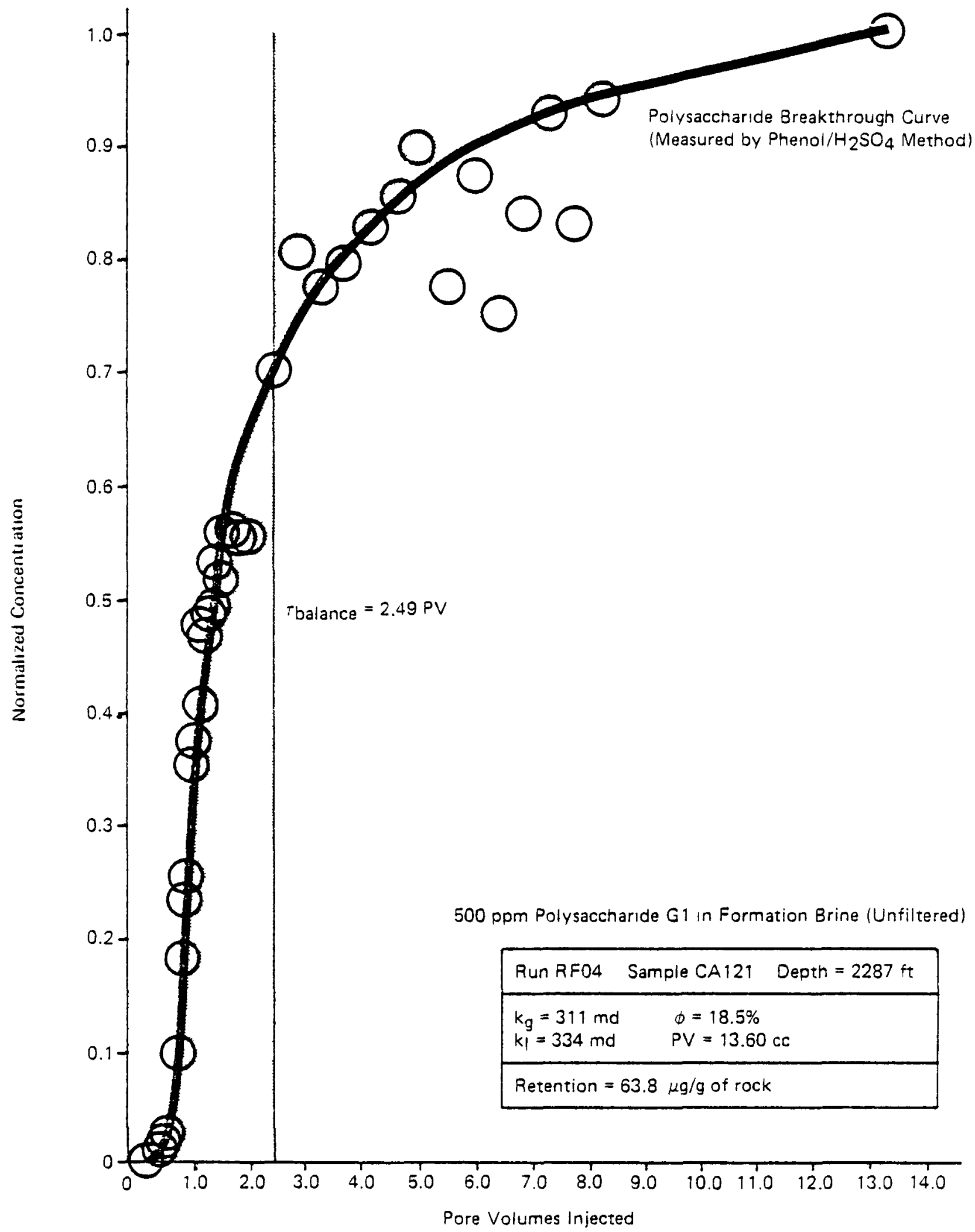

Figure 35. Breakthrough concentration profile cores (Waltersburg Formation) at $75 \pm 20 \mathrm{~F}$. 


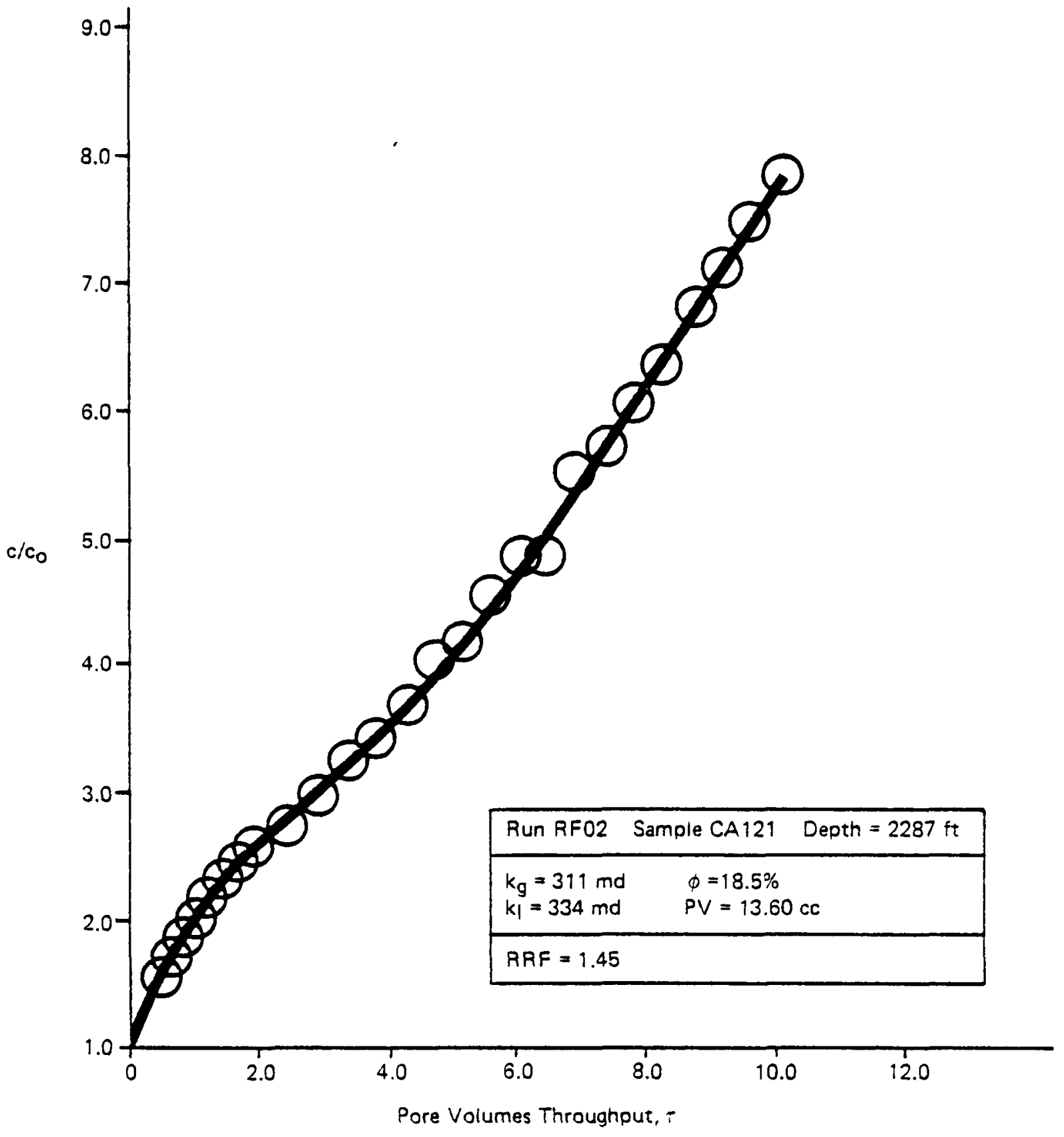

Figure 36. Resistance factor of dilute polysaccharide solution from reservoir cores at $75 \pm 2^{\circ} \mathrm{F}$. 


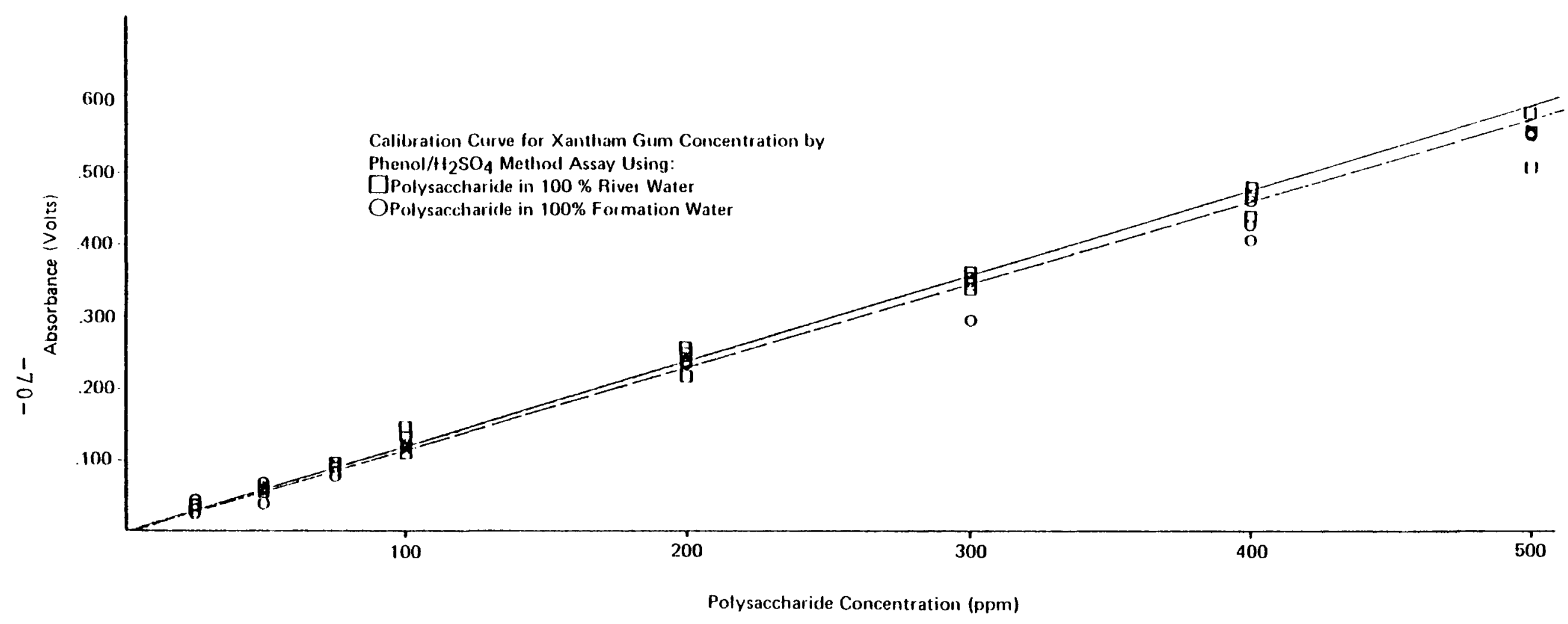

Figure 37. Calibration curve for polysaccharide concentration by the phenol/ $\mathrm{H}_{2} \mathrm{SO}_{4}$ method assay. 
The resistance factor of 500 ppm polysaccharide $\mathrm{Gl}$ in river water (filtered through a $3-5$ micron filter) begins to level out at 3.1 in Figure 30. This resistance factor is specific to the flooding velocity of $16.5 \mathrm{ft} / \mathrm{day}$. The resistance factor at field rates (e.g., I ft/day) can be obtained from the plot in Figure 30 since the shear rate is directly proportional to the flooding velocity and the logarithm of viscosity is directly related to the logarithm of shear rate. The shape of the resistance factor curves for the xanthan gum in formation brine indicates that some plugging occurs for the filtered case (Figure 32 ) but that severe plugging occurs for the unfiltered case (Figure 36).

\subsection{Eilterability}

Tests for filterability of polysaccharides through millipore filters are similar in procedure to screen factor tests for polyacrylamides but yield different interpretations. The millipore filter ratio is defined as the ratio of the time required for the last $250 \mathrm{cc}$ to the first $250 \mathrm{cc}$ of $1000 \mathrm{cc}$ of $500 \mathrm{ppm}$ polymer solution to flow through a presaturated 1.2 micron millipore filter under a constant gas pressure of 40 psi. The millipore filter ratio is a measure of the propensity of polysaccharide molecules to plug the filter and, by inference, the oil formation. Solutions with millipore filter ratios greater than 1.5 are considered unacceptable; recent specifications of polysaccharide solutions by oil companies require that the filter ratio be no greater than 1.3. The flow time at 1000 seconds is a parameter which should be considered in conjunction with the filter ratio. Filter ratios alone could be misleading in that a high degree of constant plugging could produce a low filter ratio. Pfizer has recommended that runs with flow times greater than $1000 \mathrm{sec} / \mathrm{l}$ be considered unacceptable.

Table 17 lists the millipore filter ratios and the cumulative flow times of Pfizer's polysaccharide $G$. The diluents used for these runs were all filtered through a $0.65-m i c r o n$ filter under pressure. Pfizer explained the high results of the filter ratios in runs 1 through 4 as having been caused by some resin residues from an in-line distilled water filter even though the water had been refiltered through a $0.25-m i c r o n$ filter. Pfizer conducted runs 5 through 14 in their research laboratories. Energy Resources' laboratory conducted runs 15 through 18 . The increase in millipore filter ratio between the 100 percent river water (run 10), $80 / 20 \mathrm{mixture}$ (runs 11, 12, and 13), and a 100 percent formation water (run 14) is consistent 


\section{POLYSACCHARIDE $\mathrm{G}^{\mathrm{a}}$ \\ MILLIPORE FILTER RATIOS OF 500 PPM ACTIVE \\ POLYSACCHARIDE PRODUCT UNDER A PRESSURE OF 40 PSI}

\begin{tabular}{|c|c|c|c|c|c|c|c|}
\hline $\begin{array}{l}\text { RUN } \\
\text { NO. }\end{array}$ & & $\begin{array}{r}\text { BROTH } \\
\text { (WT }\end{array}$ & $\begin{array}{l}\text { CONC. } \\
\text { 名) }\end{array}$ & $\begin{array}{l}\text { DILUENT } \\
(\% \text { RIVER } / \\
\text { ( } 8 \text { FORMATION } \\
\text { WATERS ) }\end{array}$ & $\begin{array}{c}\text { VISCOSITY } \\
(\mathrm{cp} a \\
6 \text { rpm) }\end{array}$ & $\begin{array}{c}\text { FLOW } \\
\text { TIME } \\
(\text { ( } 1000 \mathrm{cc})\end{array}$ & $\begin{array}{l}\text { MILLI PORE } \\
\text { FILTER } \\
\text { RATIO }\end{array}$ \\
\hline 1 & & 2.7 & & $80 / 20$ & 9.6 & 89.59 & 1.97 \\
\hline 2 & & 2.7 & & $80 / 20$ & 9.6 & 94.61 & 2.27 \\
\hline 3 & & 2.7 & & $80 / 20$ & 9.6 & 91.19 & 2.10 \\
\hline 4 & & 2.7 & & $d$ & 9.8 & 51.81 & 1.97 \\
\hline 5 & Gl & 2.7 & & $80 / 20$ & 9.9 & 40 & 1.14 \\
\hline 6 & & 2.7 & & $80 / 20$ & 9.9 & 43 & 1.17 \\
\hline 7 & & 2.7 & & $80 / 20$ & 9.3 & 35 & 1.32 \\
\hline 8 & & 2.7 & & $80 / 20$ & 9.3 & 31 & 1.30 \\
\hline 9 & G2 & 5.7 & & -- & -- & -- & -- \\
\hline 10 & & 7.4 & & $100 / 0$ & 10.3 & 61 & 1.16 \\
\hline 11 & G3 & 7.4 & & $80 / 20$ & 10.1 & 83 & 1.37 \\
\hline 12 & & 7.4 & & $80 / 20$ & 9.9 & 80 & 1.30 \\
\hline 13 & & 7.4 & & $80 / 20$ & 9.9 & 75 & 1.30 \\
\hline 14 & & 7.4 & & $0 / 100$ & 10.3 & 285 & 2.9 \\
\hline 15 & & 8.4 & & $100 / 0$ & 10.0 & 51 & 1.60 \\
\hline 16 & G4 & 8.4 & & $100 / 0$ & 10.0 & & 1.57 \\
\hline 17 & & 8.4 & & $80 / 20$ & 10.6 & 63 & 1.76 \\
\hline 18 & & 8.4 & & $80 / 20$ & 10.6 & & 1.60 \\
\hline
\end{tabular}

a polysaccharide from manufacturer $G$ is made in four different concentrations $(\mathrm{Gl}=2.7 \%, \mathrm{G} 2=5.78, \mathrm{G} 3=7.48, \mathrm{G} 4=8.48)$.

$\mathrm{b}_{250}$ ppm TDS with 2:1:: Na+: $\mathrm{Ca}++$

$\mathrm{C}_{38,500}$ ppm TDS with $19: 1:: \mathrm{Na}: \mathrm{Ca}++$

$\mathrm{d}_{500}$ ppm TDS with 10:1:: Na+:Ca++ 
with the high retention of polysaccharide $G 2$ measured by Core Laboratories in reservoir cores in the $80 / 20 \mathrm{mixture}$ (321 lb/acre-ft) and in 100 percent formation water ( 542 $1 b / a c r e-f t)$.

The results of filterability tests carried out by Core Laboratories are plotted in terms of filter rate ( $\mathrm{ml} / \mathrm{sec}$ ) versus cumulative throughput ( $\mathrm{ml}$ ) in Figures 38 through 43 . These representations combine the effects of incremental plugging (slope of curve) and initial plugging tendencies (initial flcw rate) of dilute polysaccharide solutions. These curves indicate that biopolymer $G l$ has a better filterability than biopolymer $\mathrm{H}$ but that biopolymer $\mathrm{Gl}$ is much more affected by the presence of divalent and univalent electrolytes than biopolymer $H$. These results support the assertion that high retention of polysaccharide $\mathrm{Gl}$ in reservoir cores is caused by microgel formation cross-linked with polyelectrolytes. Core Laboratories stated that the quality of filterability data was poor for biopolymer $G 2$ and did not report these results. G3 and $G 4$ are new products from Pfizer which were not tested by Core Laboratories.

Energy Resources also measured the millipore filter ratios of candidate polysaccharides. The results, plotted in Figure 44 and summarized in Table 18, indicate that with respect to filtration time and rate the Pfizer polysaccharides performed best. Filtration of the polysaccharides in distilled water indicated that the Kelco and Abbott brotrs would require diatomaceous earth filtration before injection.

The compatibility of Pfizer's Flocon 1035 with different biocides at varying concentrations (10,50 and $100 \mathrm{ppm}$ ) in distilled water is illustrated in Figures 45 through 52 . Baseline curves of filtration time and filtration rate are plotted in Figures 45 and 49. The filterabilities of the solutions appear to decrease with increasing concentrations of biocide, although as with the viscosity measurements discussed in section 3.1.3 there is no consistent pattern to the curves.

\subsection{Conclusions of the Polymer Selection Program}

The results of the compatibility studies can be summarized by the following statements:

- The polyacrylamides are much more viscous than the polysaccharides at equivalent concentrations of fresh water, but the viscosities of these polyacrylamides are much more sensitive to saline water than 


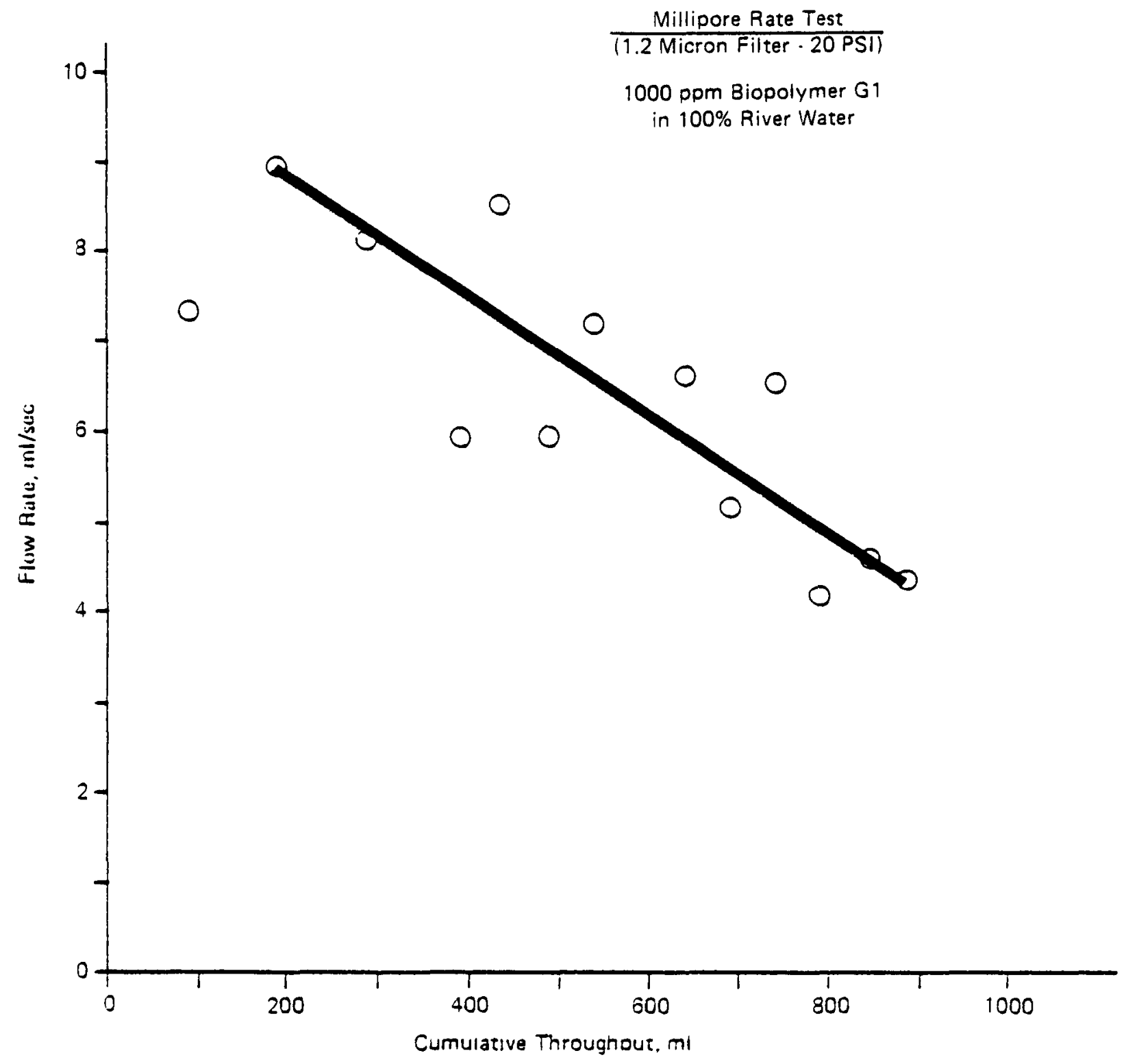

Figure 38. Results of Core Laboratories' millipore filter tests for polysaccharide $G 1$ at $1000 \mathrm{ppm}$ in pure river water. 


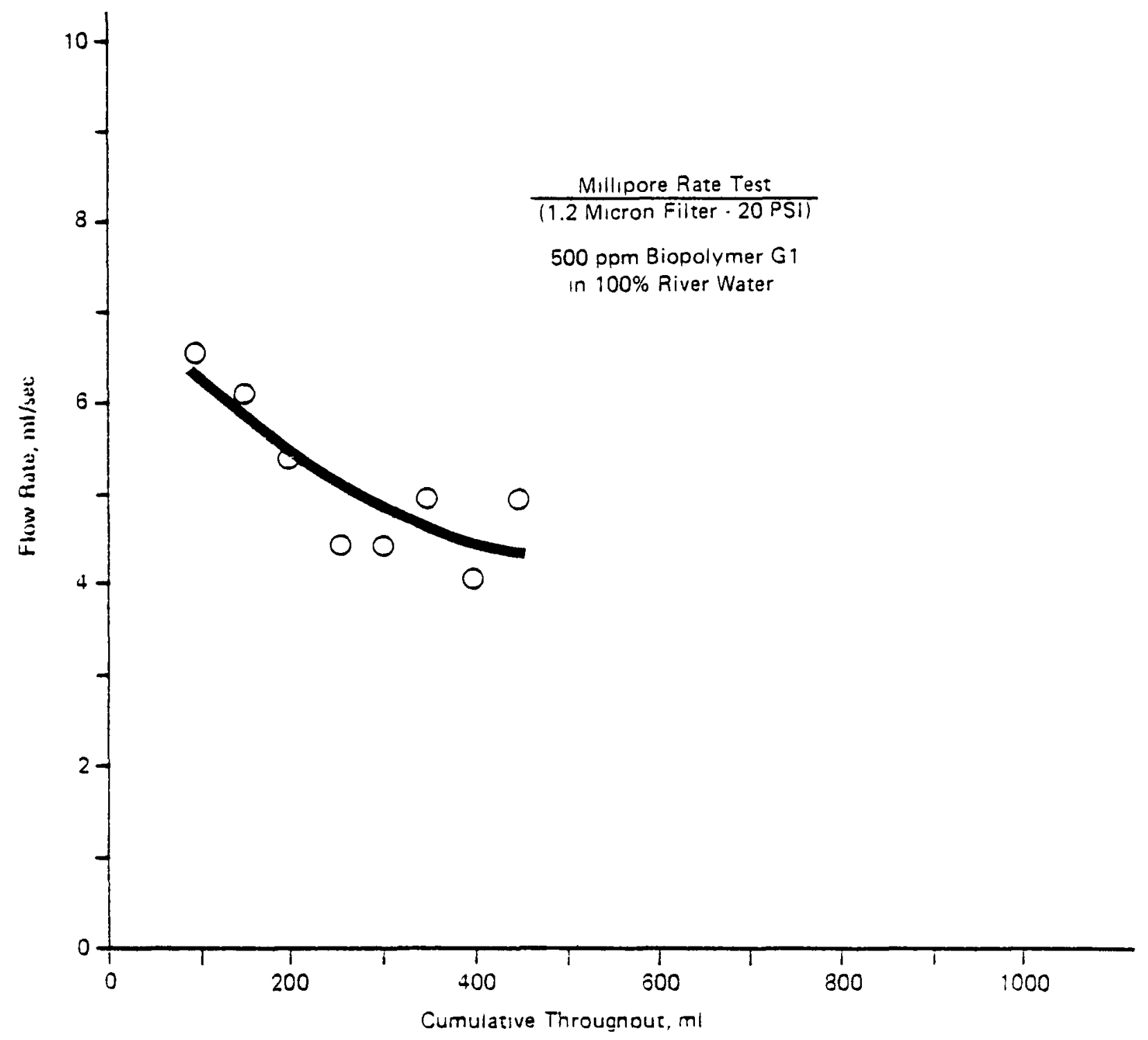

Figure 39. Results of Core Laboratories' millipore filter tests for polysaccharide $G 1$ at $500 \mathrm{ppm}$ in pure river water. 


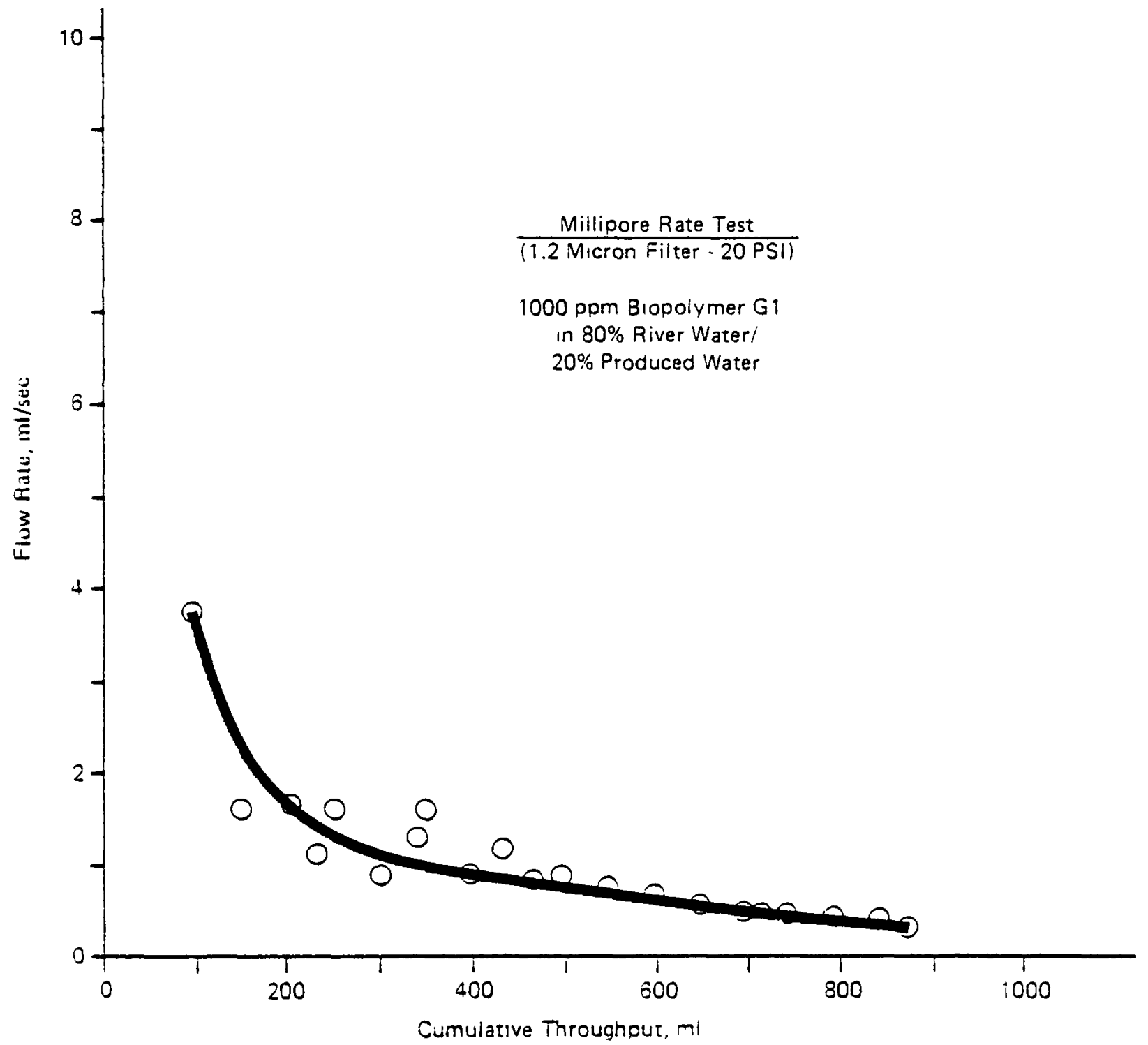

Figure 40. Results of Core Laboratories' millipore filter tests for polysaccharide $G 1$ at $1000 \mathrm{ppm}$ in an 80/20 mix of river and formation waters. 


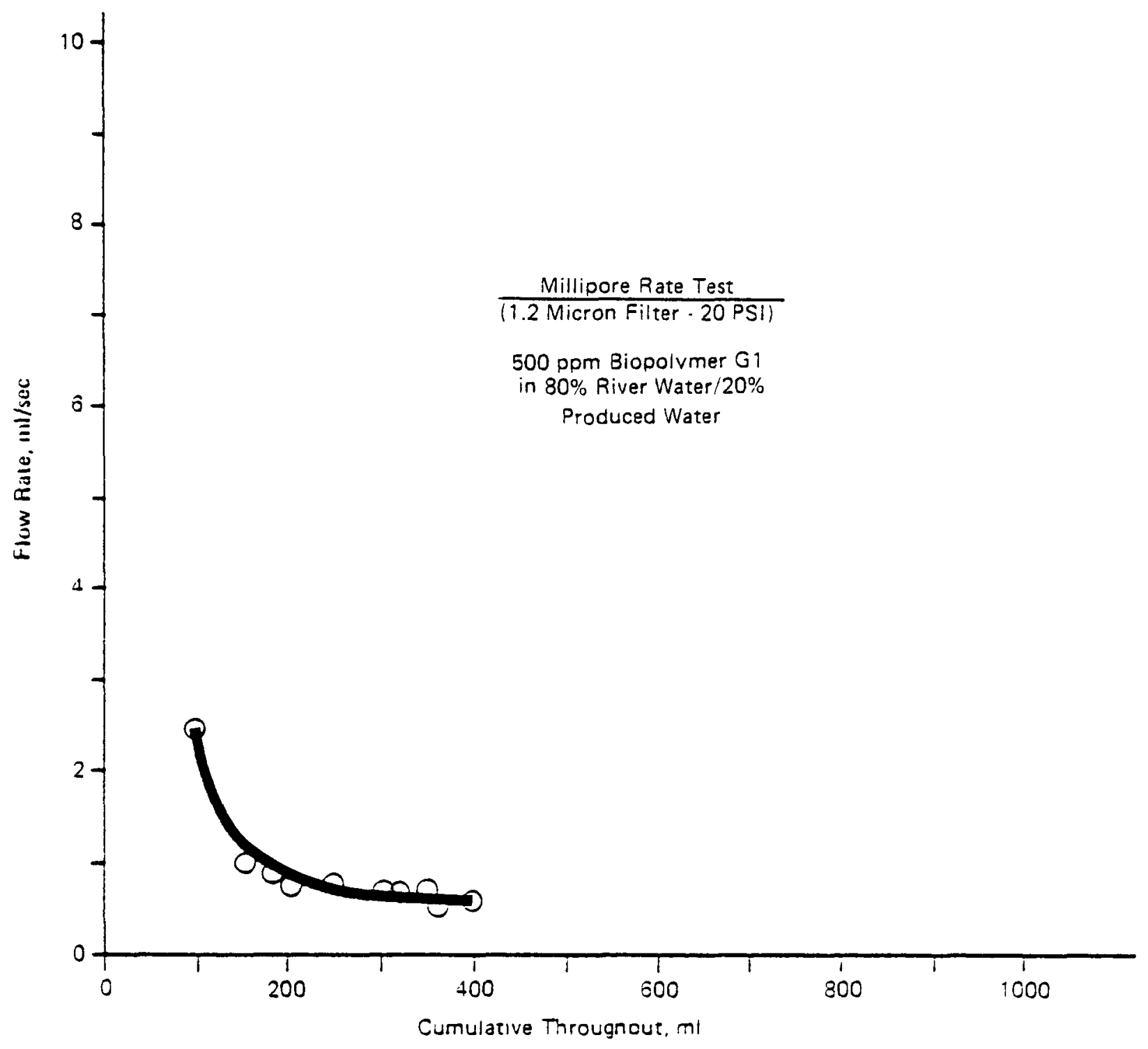

Figure 41. Results of Core Laboratories' millipore filter tests for polysaccharide $G 1$ at $500 \mathrm{ppm}$ in an $80 / 20 \mathrm{mix}$ of river and formation waters. 


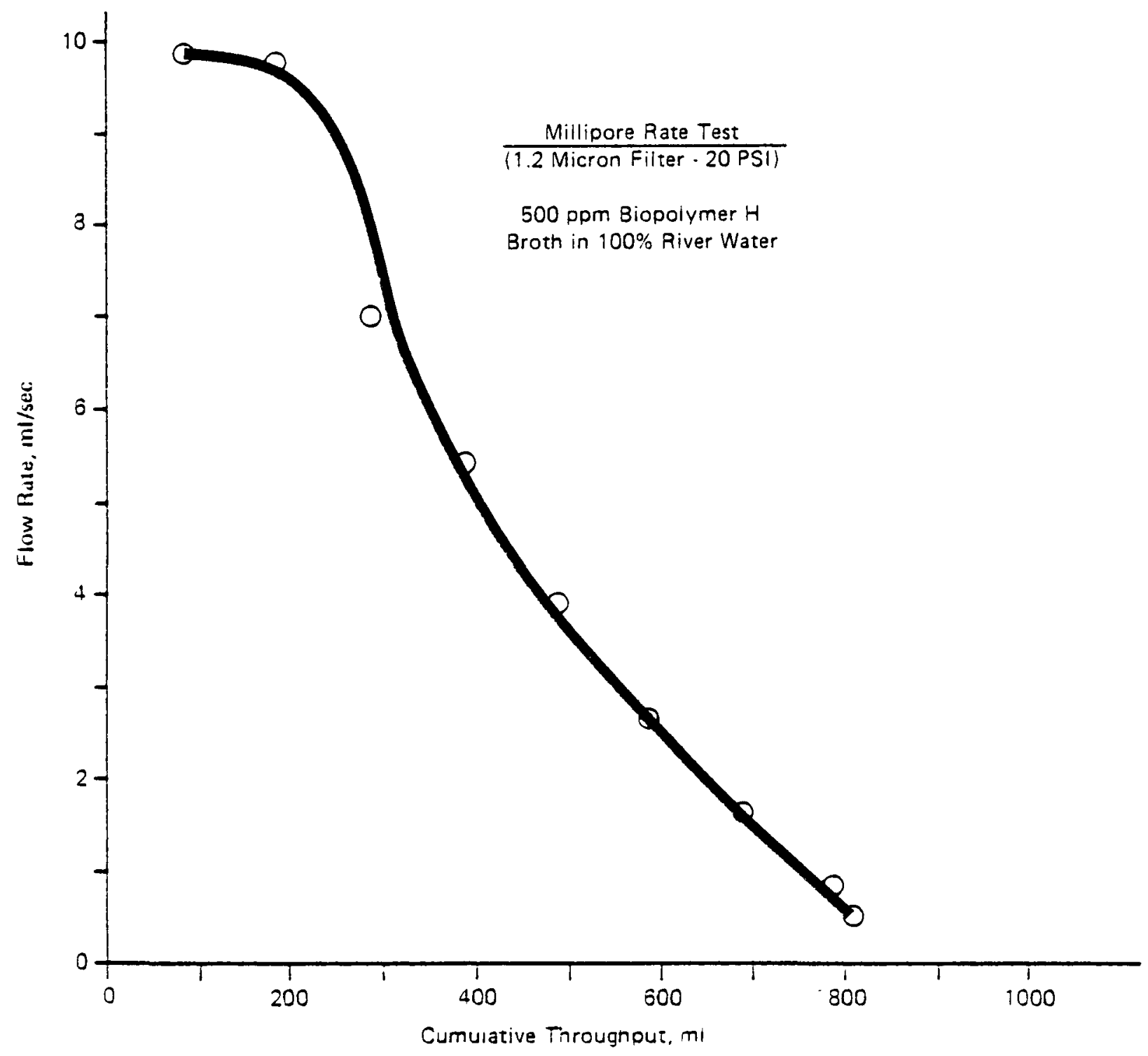

Figure 42. Results of Core Laboratories' millipore filter tests for polysaccharide $H$ at 500 ppm in pure river water. 


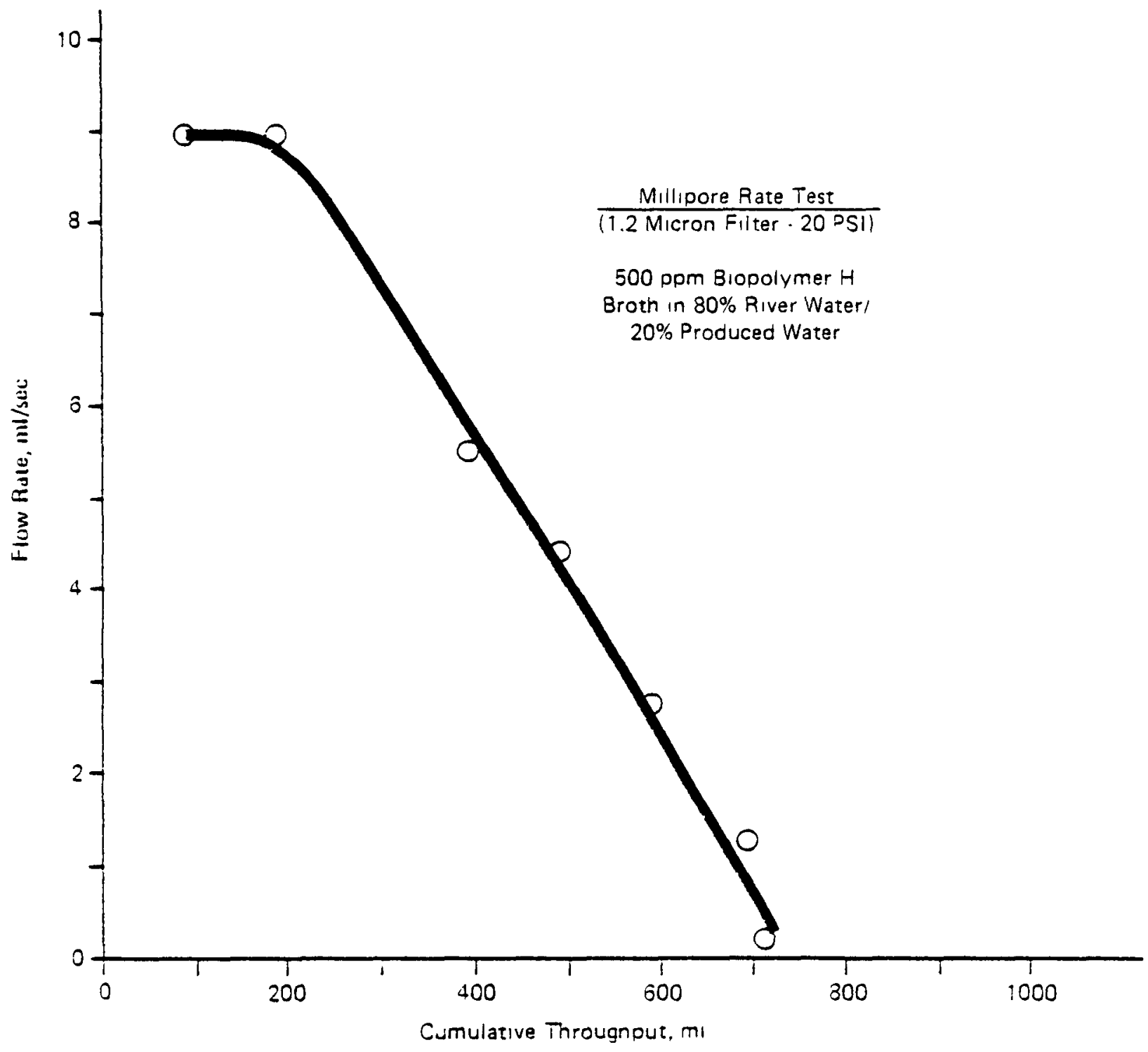

Figure 43. Results of Core Laboratories' millipore filter tests for polysaccharide $H$ at $500 \mathrm{ppm}$ in an 80/20 mix of river and formation waters. 


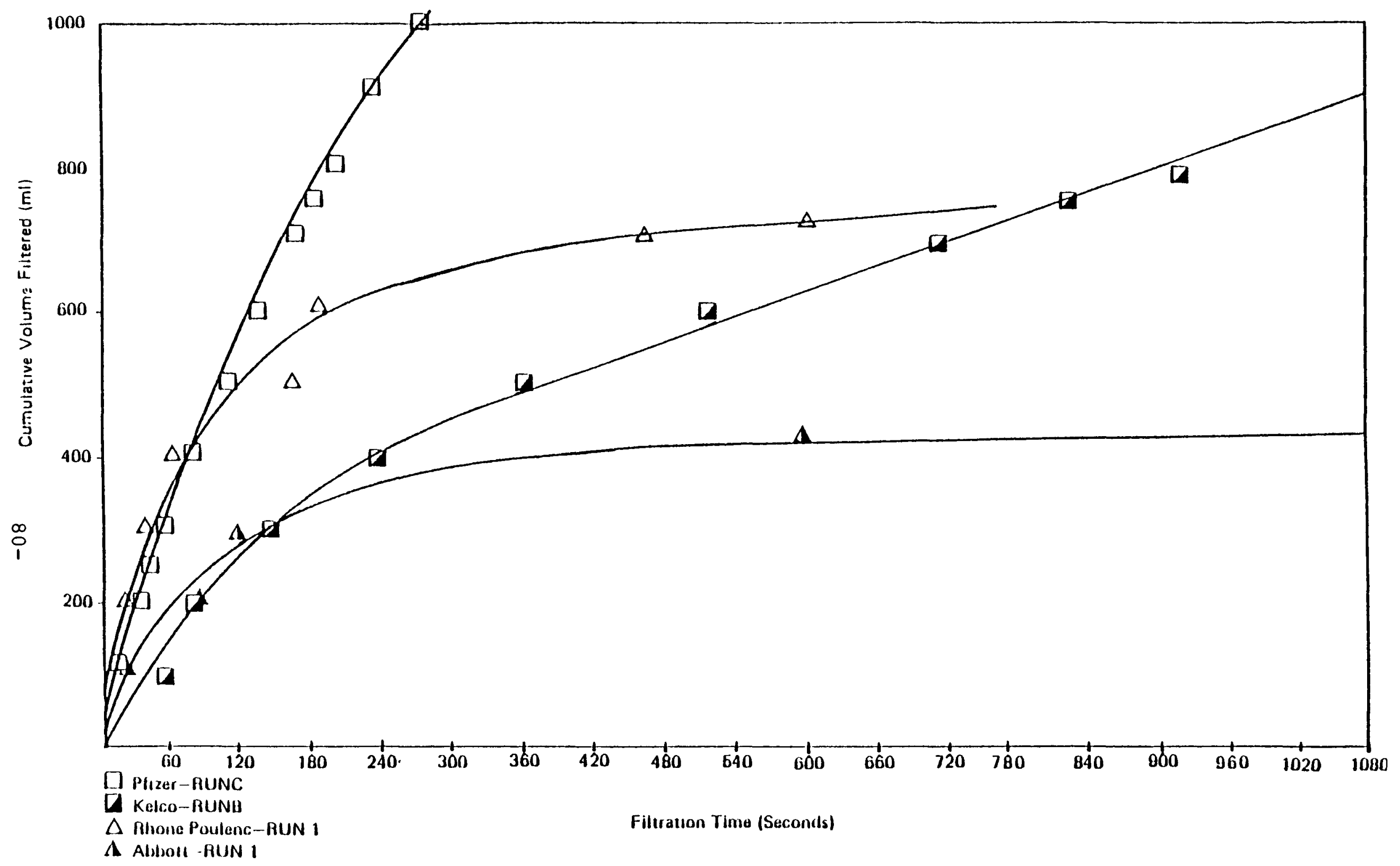

Figure 44. Filterability of dilute polysaccharide solutions (500 ppm active polymer) of xanthan gum broths. 


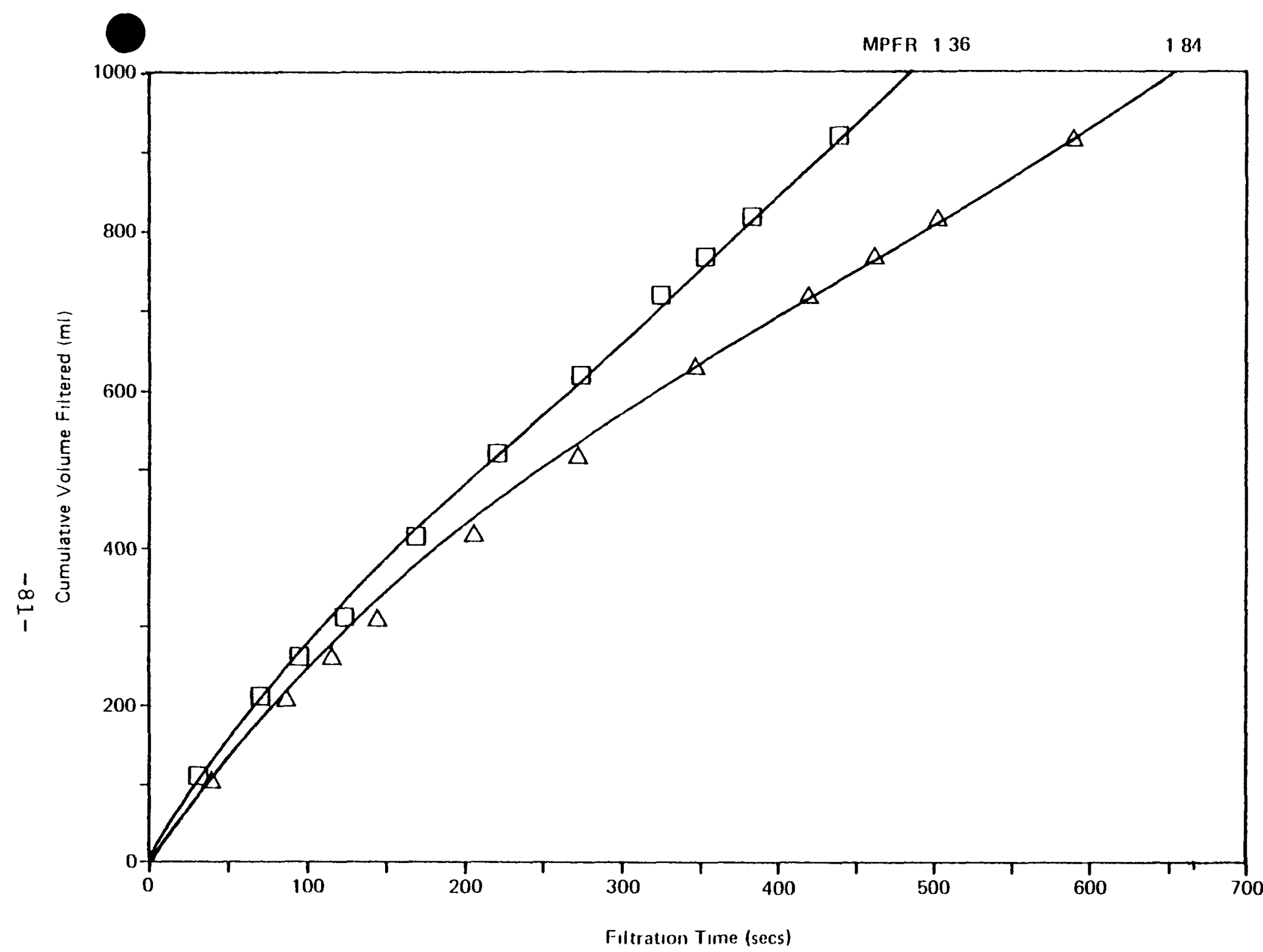

500 ppin Xanthan Distilled $\mathrm{H}_{2} \mathrm{O}$ (Filtered) $40 \mathrm{ps} \mathrm{N}_{2}$

12 Micron Filter

$\triangle$ First Pass

$\square$ Second Pass

Figure 45. Filtration time curves for polysaccharıde GI. 


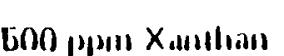

Disilllead Walter (Filleated)

40 pse $\mathrm{N}_{2}$ Overpressuma

1.2 incion filler
FOIIMAIDEIIYOE

First Pass $\triangle 10$ (PIIII

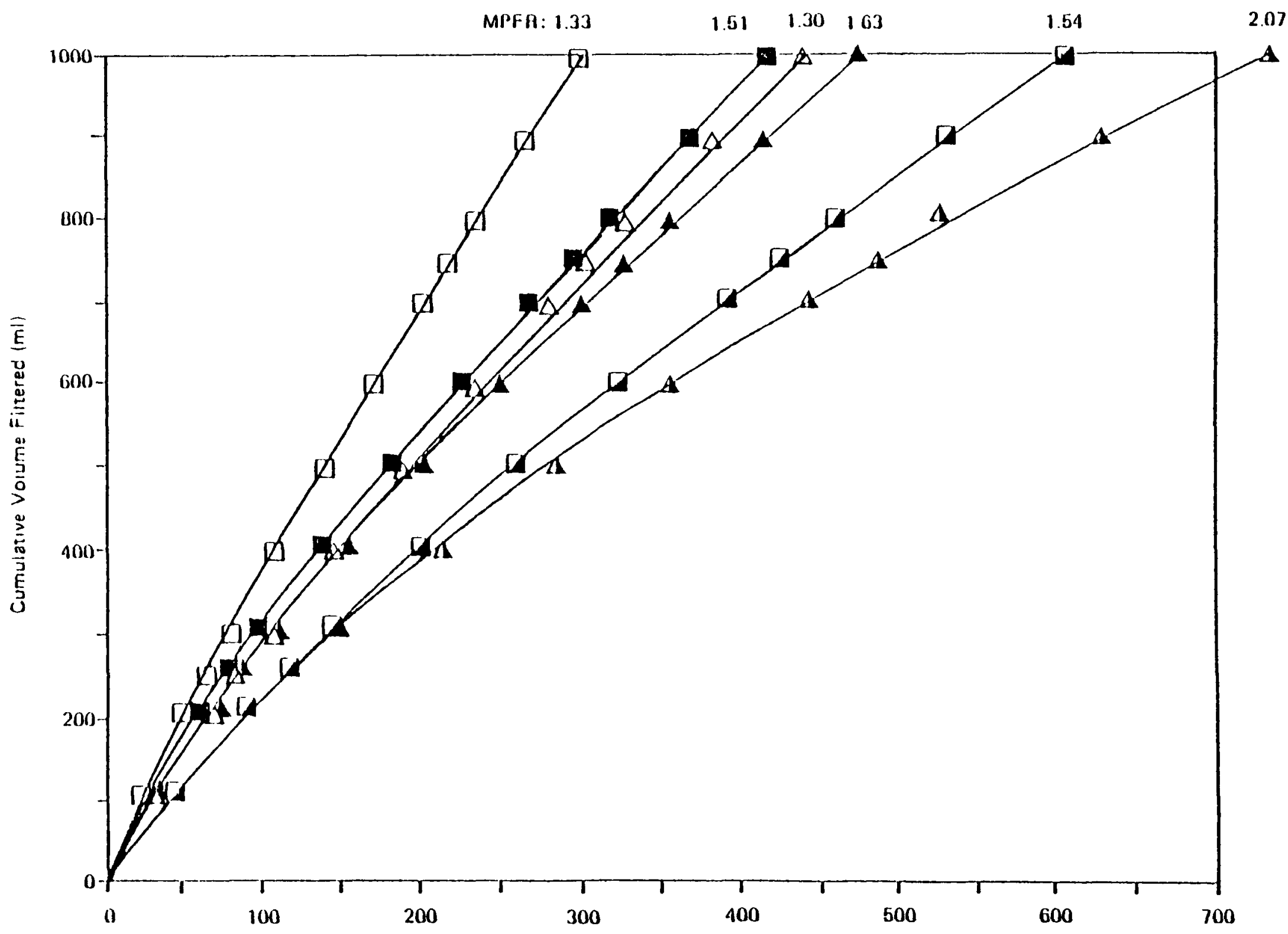

Filliation Time (sec)

Figure 46. Filtration time curves for polysaccharide G1 with formaldehyde. 
1.2 micton Filter

$\begin{array}{lccc} & 10 \mathrm{ppin} & 50 \mathrm{ppm} & 100 \mathrm{ppm} \\ \text { First Pass } & \triangle & \Delta & \Delta \\ \text { Second Pass } & \square & \square & \end{array}$

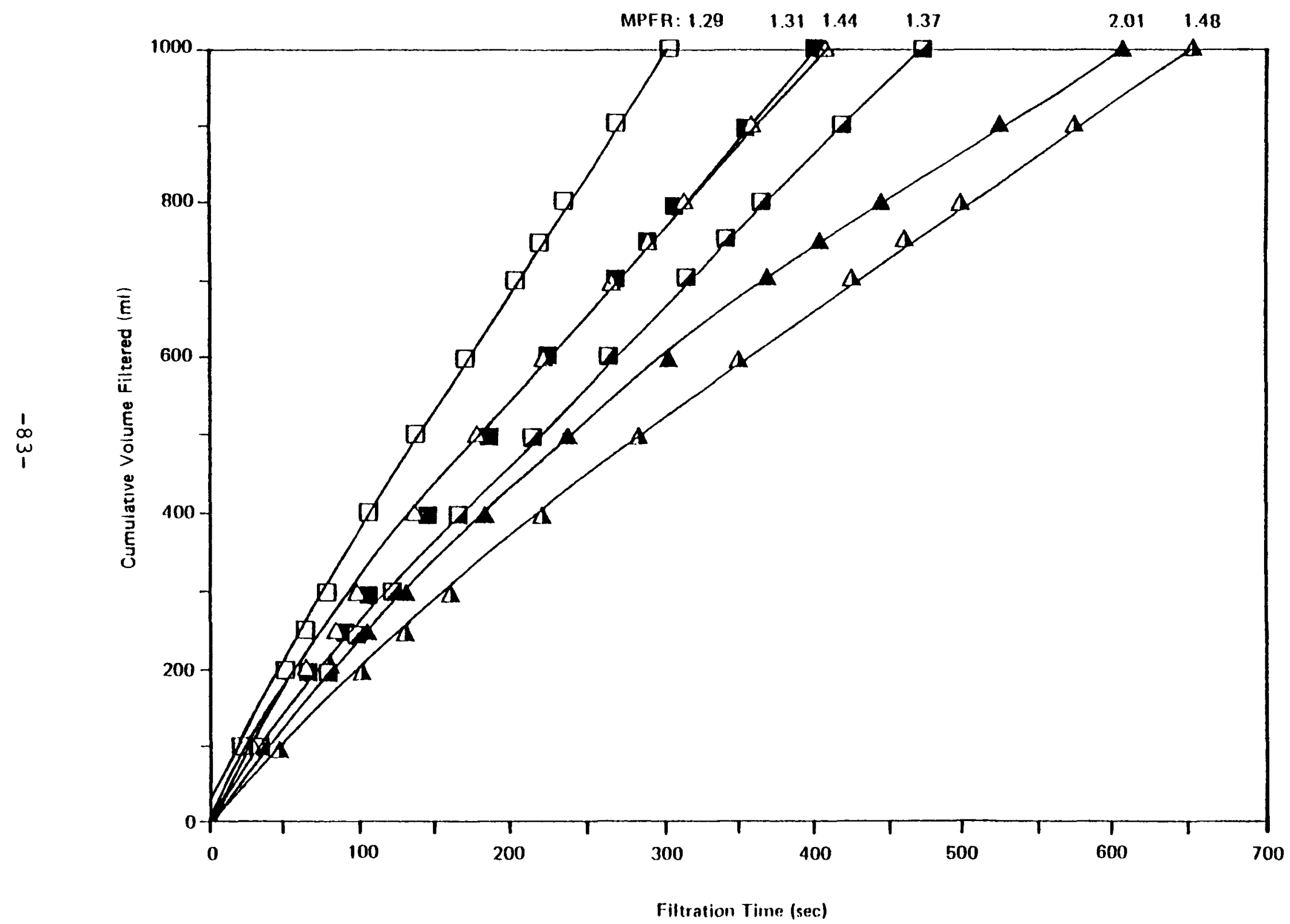

Figure 47. Filtration time curves for polysaccharide G1 with acrolein. 
500 ppm Xanthail Distilled Water (Filtered)

40 psi $\mathrm{N}_{2}$ Oveipressure

12 micron Filter
VISCO 3991

First Pass $10 \mathrm{ppm} 50 \mathrm{ppm} 100 \mathrm{pmm}$

Second Pass $\square$

$\Delta \quad \Delta$

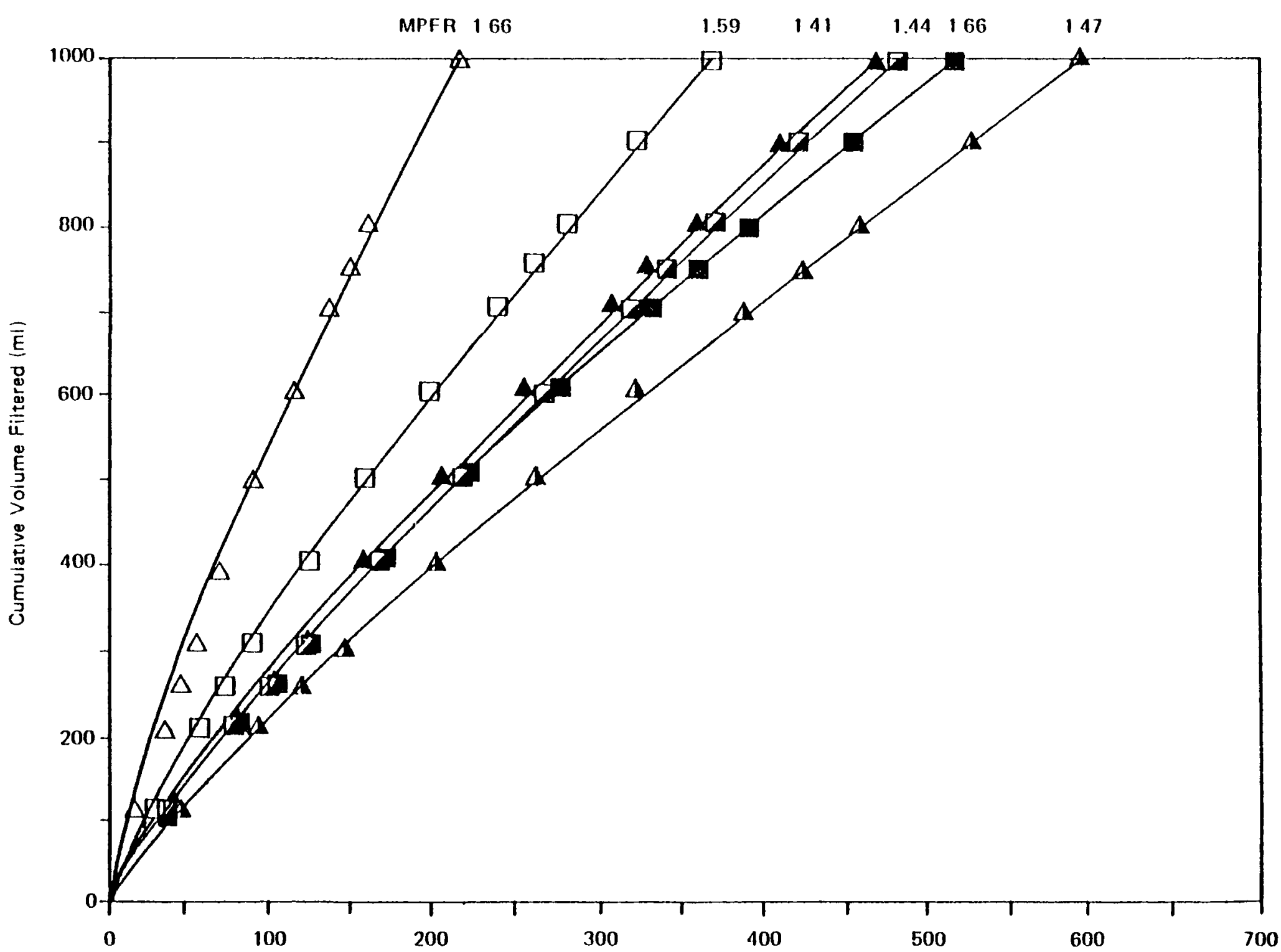

Filtration Time (sec)

Figure 48. Filtration time curves for polysaccharide G1 with Visco 3991. 


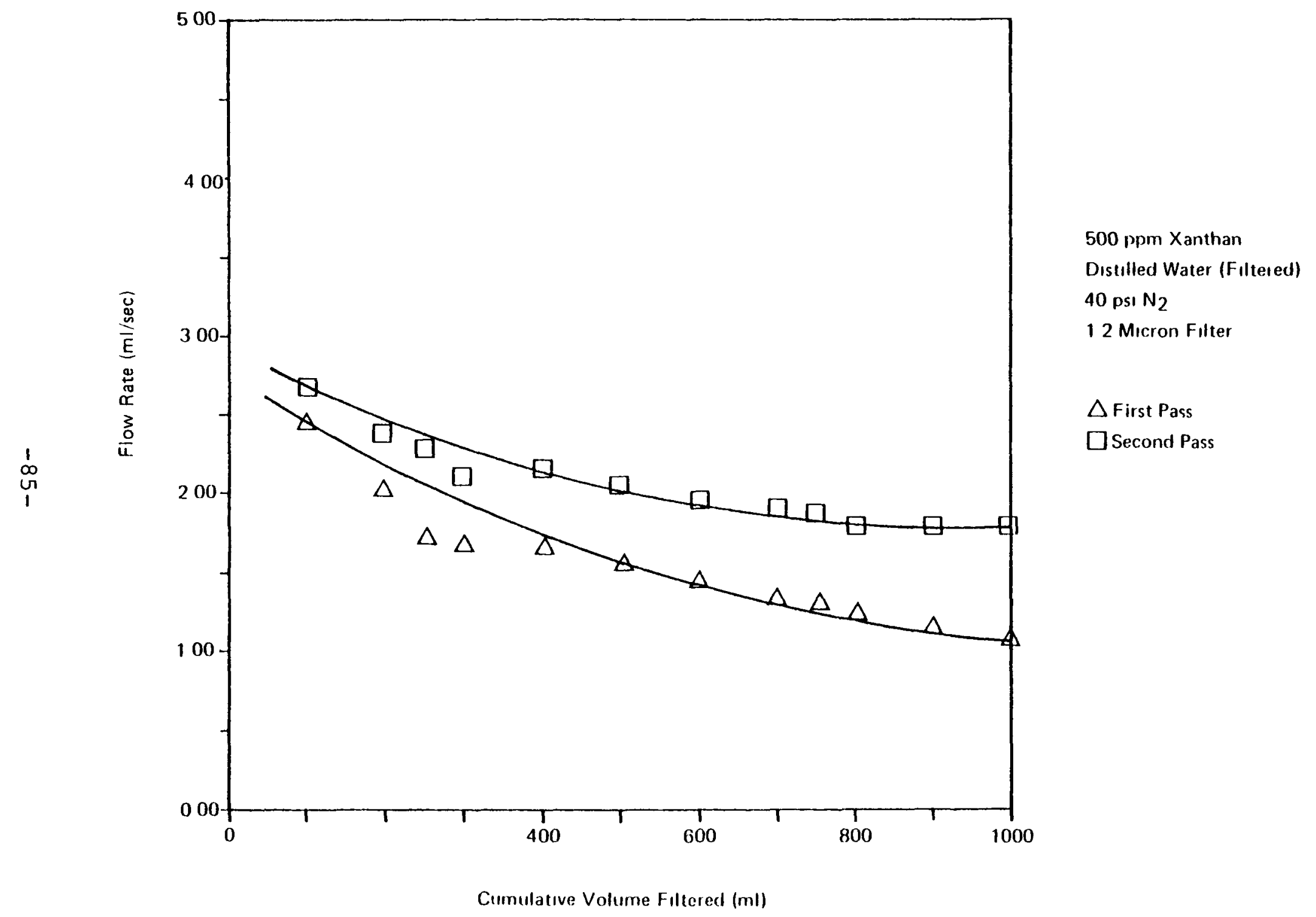

Figure 49. Filtration time curves for polysaccharide GI. 


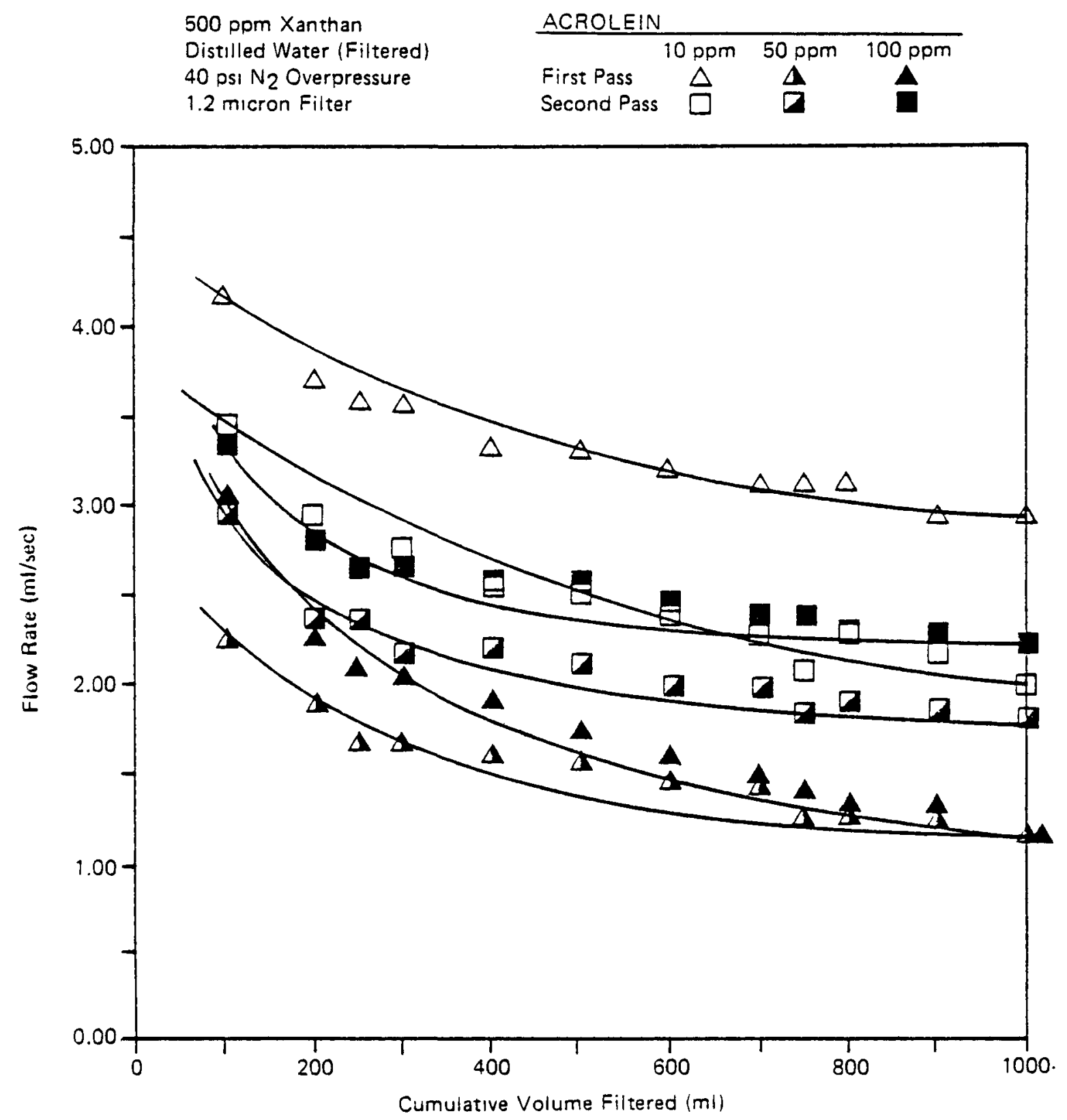

Figure 50. Filtration time curves for polysaccharide $G 1$ with acrolein. 
500 ppm Xanthan

Distilled Warer (Filtered)

40 psi $\mathrm{N}_{2}$ Overpressura

1.2 micron Filter
FORMALDEHYDE

10 ppm 50 ppm 100 ppm

First Pass $\triangle$

Second Pass

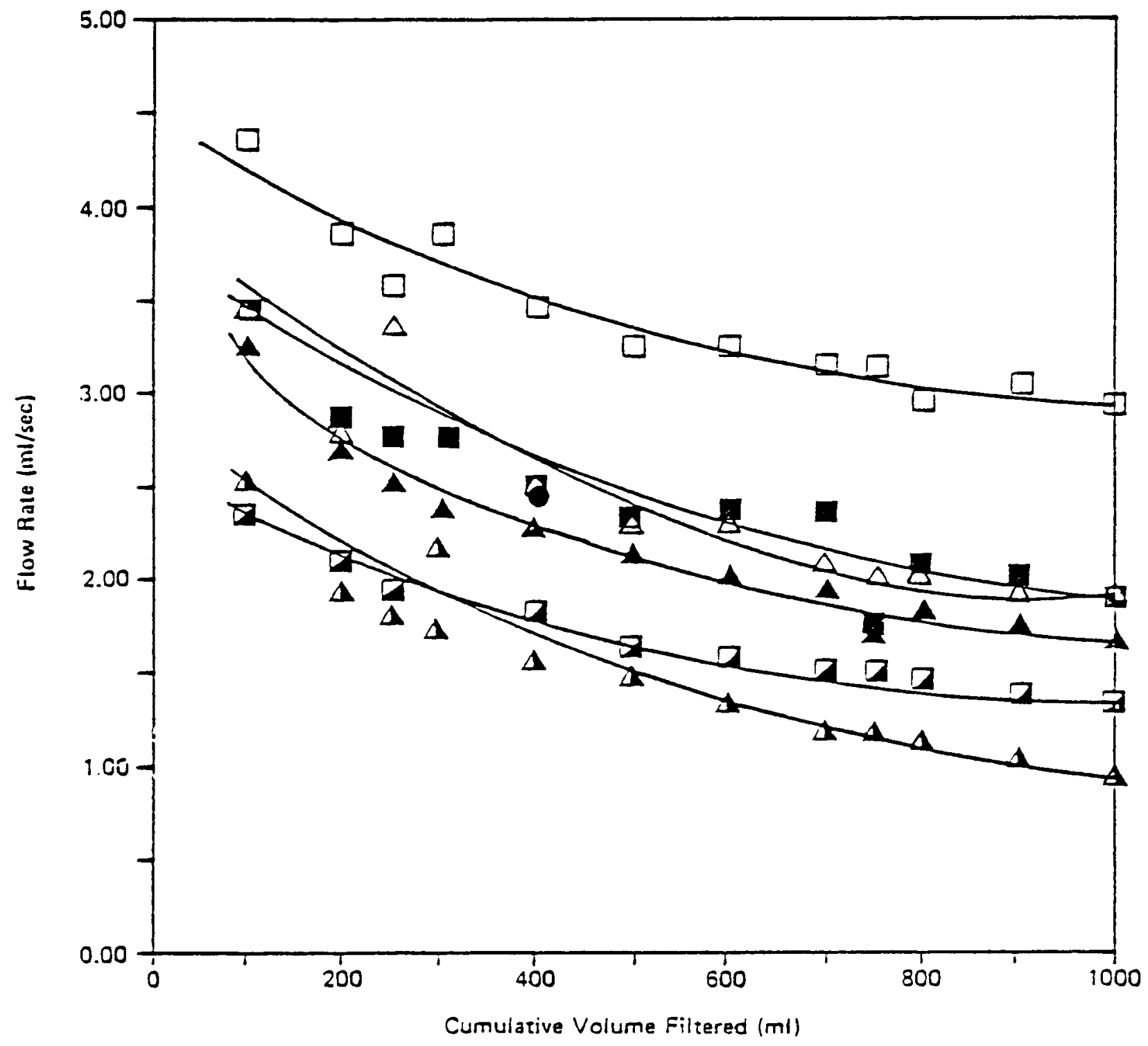

Figure 51. Filtration time curves for polysaccharide $\mathrm{G} 1$ with formaldehyde. 


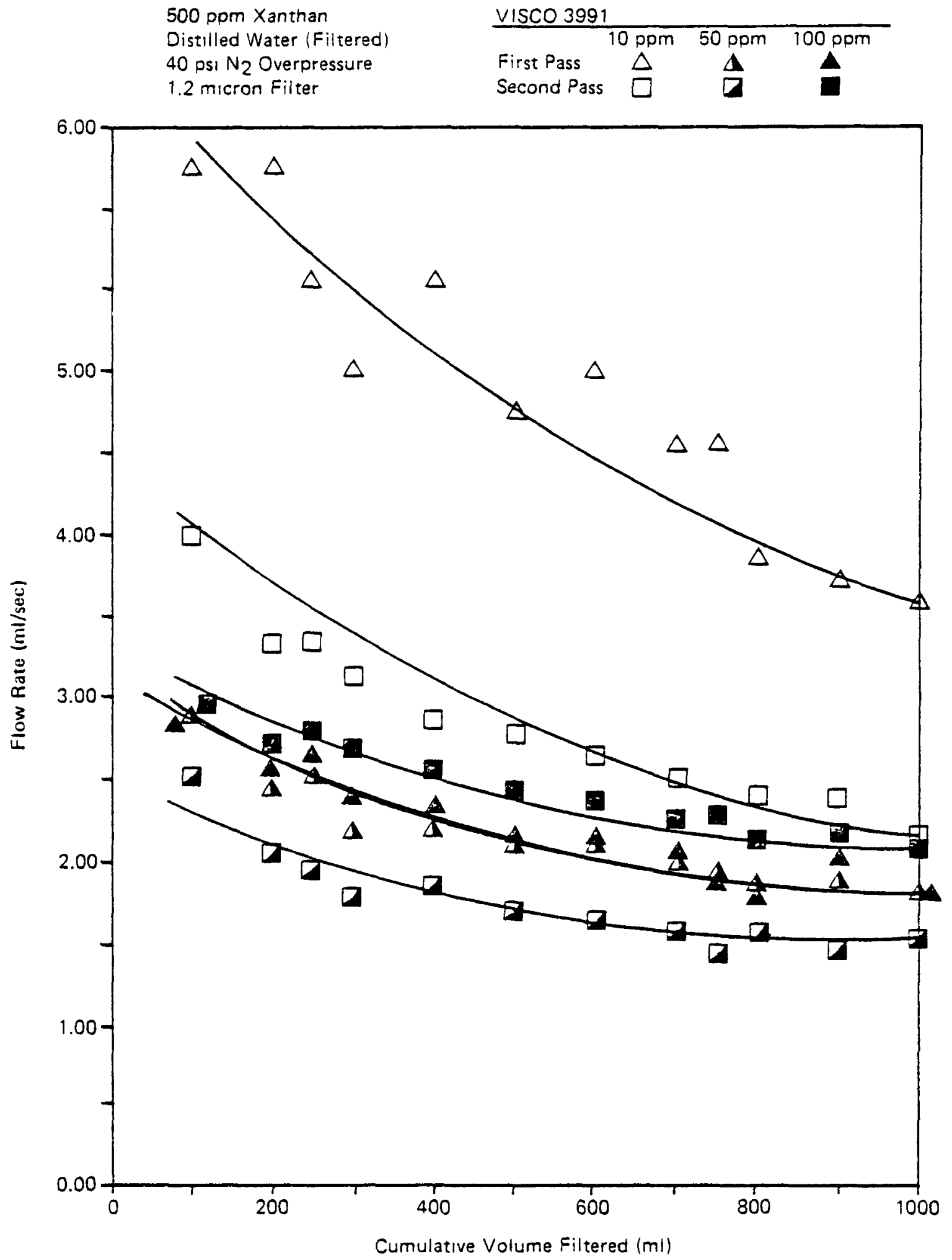

Figure 52. Filtration time curves for polysaccharide G1 with Visco 3991. 
those of the polysaccharides. The viscosity of the polyacrylamides degrades by an order of magnitude on increase of the salt concentration from $189 \mathrm{ppm}$ to 7,844 ppm (see Table 9).

- Analysis of the sensitivity of these polymers to rotational shear suggests that some permanent loss of viscosity could occur at the wellbore for the polyacrylamides but not the polysaccharides.

In addition, the results of the microbiological study reported in section Four suggest that polysaccharides may be subject to deleterious effects of microbial attack. Compatibility tests between a polysaccharide and various biocides yielded the following result:

- The viscosity of Pfizer's Flocon 1035 (polysaccharide Gl) increases with increasing concentration of the biocides acrolein, formaldehyde, and Visco 3991. This increase is attributed to cross-linking among the polysaccharide chains.

The investigation of rheologic and retentive behavior in reservoir cores led to the following conclusions:

- The high RF and RRF of polyacrylamides $E$ is consistent with their high screen factors. Some injectivity problems were encountered with polymer El; there were no injectivity problems with polymer $E 2$, which with a

TABLE 18

MILLIPORE FILTER RATIOS MEASURED BY ENERGY RESOURCES FOR CANDIDATE POLYSACCHARIDES

\begin{tabular}{|c|c|c|}
\hline & \multicolumn{2}{|c|}{ MILLIPORE FILTER RATIO } \\
\hline & FIRST PASS & SECOND PASS \\
\hline Pfizer & 1.98 & 1.41 \\
\hline Kelco & 7.43 & 1.68 \\
\hline Rhone-Poulenc & Terminated & 2.66 \\
\hline Abbott & Terminated & Terminated \\
\hline
\end{tabular}


lower molecular weight has a lower intrinsic viscosity than El. The high RF of polyacrylamides $E$ and the relative ease of injection could have resulted from their extended molecular length and linearity, likely byproducts of the gamma radiation manufacturing process.

- Polyacrylamides such as $C$ and $D$, which had high electrochemical degradation factors, exhibited plugging behavior and low $R F$ in the reservoir cores.

- Polysaccharide G2 had an unusually high RRF (9.3) and retention rate $(321 \mathrm{lb} /$ acre- $f t)$ in an unfiltered $80 / 20$ mix of river and formation waters. The high retention and $R R F$ probably resulted from mechanical entrapment of microgels (reversible complexes of divalent cations with polysaccharide molecules) formed in the $80 / 20$ mixture. Tests in unfiltered 100 percent formation water indicated higher retention ( $542 \mathrm{lb} / \mathrm{acre}-\mathrm{ft})$ in the reservoir cores. The retention rates were significantly lower ( $95 \mathrm{lb} /$ acre-ft in river water; $120 \mathrm{lb} /$ acre-ft in formation water) when the polymer solutions were filtered.

Filterability tests showed considerable variation among the polysaccharides. Pfizer's Flocon 1035 yielded the best results; the ratios for Kelco and Abbot products indicated that these polysaccharides would need to be filtered through diatomaceous earth before injection. Addition of biocides decreased the filterability of the Pfizer polymer tested.

The costs per active pound of the candidate polymers as of mid-1979 are shown in Table 19. In general, the polyacrylamides are cheaper per active pound than the polysaccharides. These cost differences must be weighed with expected field performance and the likelihood of technical success of the flood based on the laboratory experiments.

All polymers tested appeared capable of yielding mobility ratios reliably less than l.0 (i.e., favorable) under reservoir conditions. Therefore the higher RF of polyacrylamides in fresh water poses no great advantage over polysaccharides, since marginal improvement in areal sweep efficiency is small for decreasing mobility ratios lower than unity. The sensitivity. of polyacrylamides to salts and shear at the wellbore are negative factors which are difficult to overcome, whereas the microgel formation and possible susceptibility to microbiological degradation found in polysaccharides are probably mitigable. Among the polysaccharides, Pfizer's Flocon 1035 was judged the best candidate for injection. Table 20 summarizes the properties of this polymer which will be used in further design and simulation of the polymer flood. 
TABLE 19

COSTS OF POLYMERS PER ACTIVE POUND, MID-1979

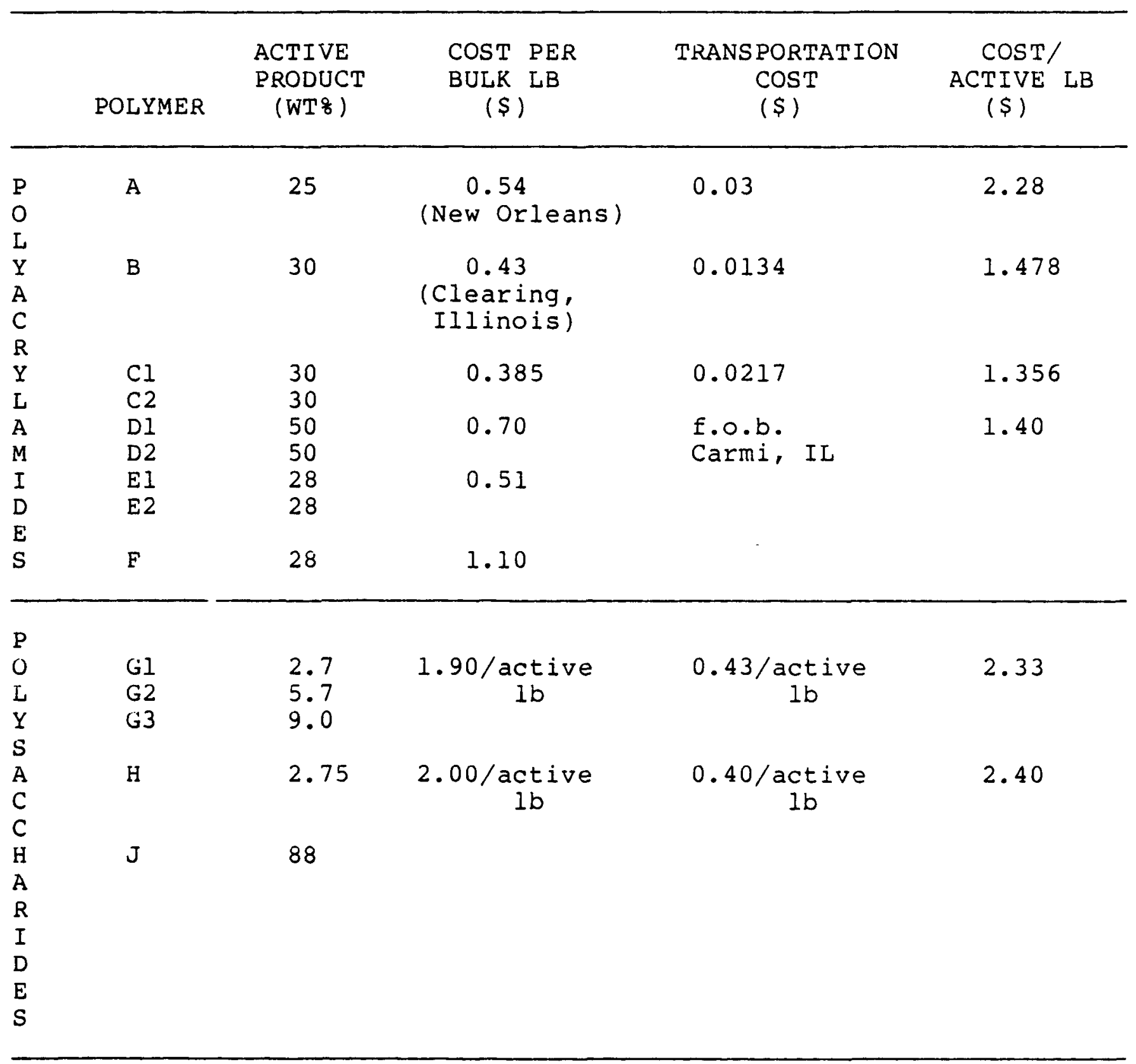


SUMMARY UF CHARACTERISTICS OF PFIZER'S FLOCON 1035 (POLYSACCHARIDE GI)

Delivered state

Injected concentration

Electrochemical degradation factor

Sensitivity to shear degradation

Susceptibility to microbial attack

Resistance factor

Residual resistance factor

Retention rate
Broth

500 ppm

1.1

small and reversible

sufficient to require biocides

$10 \mathrm{a}$

approximately $1.2^{b}$

$16.34 \mu \mathrm{g} / \mathrm{g} \mathrm{rock}^{\mathrm{b}}$

Assumed completely attributable to viscosity increase.

$b_{\text {Assuming dilute polymeric solutions are filtered }}$ through a 1.2 micron filter.

\subsection{Slug Design}

The concentration of the injected polysaccharide slug will be tapered at its trailing edge to mitigate viscous fingering by the drive water injected after it. The slug will also include a buffer of full-strength (500 ppm) polymer solution sacrificed to retention. The tapered trailing edge, or viscous buffer, and the retention buffer together are intended to ensure the integrity of the slug as it flows from injectors to producers, thereby optimizing the flood's areal sweep efficiency.

The objective in the viscous buffer calculation is to design several stages of decreasing polymer concentration, each of whose volume is just large enough to withstand viscous fingering from the upstream stage over the length of the flood. Ideally, then, viscous fingering at the trailing edge will destroy the slug's integrity just as the leading edge reaches the producers. A method for designing such a tapered slug is 
described by $\mathrm{Claridge.} 4$ For ease of implementation in the field, this method is applied assuming five stages $V_{I}$,

$v_{2}, \ldots, V_{5}$ of concentration $500 \mathrm{ppm}, 400 \mathrm{ppm}, \ldots .100 \mathrm{ppm}$, respectively. The viscosity of each stage is estimated by linear interpolation:

$$
\mu(\mathrm{C})=0.85+0.0153 \mathrm{C}
$$

where $C$ is expressed in ppm and $\mu$ in $\mathrm{cp}$. A residual resistance factor of 1.2 is assumed.

The method computes $v_{1}, \ldots, V_{5}$ as fractions of total pore volume contacted using factors $\mathrm{K}_{1}, \ldots, \mathrm{K}_{5}$ describing the mixing zones in the stages:

$$
K_{i}=\left[0.78+0.22\left(M_{i}\right)^{1 / 4}\right]^{4}
$$

Here $M_{i}$ is the mobility ratio between stage $i$ and the fluid upstream of it. Table 21 lists the results of these calculations using Claridge's equations.

TABLE 21

\section{CALCULATION OF GRADED POLYMER SLUG STAGES FOR VISCOUS BUFFER}

\begin{tabular}{ccccc}
\hline $\begin{array}{c}\text { STAGE } \\
I\end{array}$ & $\begin{array}{c}\text { POLYSACCHARIDE } \\
\text { CONCENTRATION } \\
C_{i}(\text { pPM) }\end{array}$ & $\begin{array}{c}\text { MOBILITY } \\
\text { RATIO Mi }\end{array}$ & $\begin{array}{c}\text { MIXING } \\
\text { FACTOR } K_{i}\end{array}$ & $\begin{array}{c}\text { FRACTION OF } \\
\text { CONTACTED } \\
\text { PORE VOLUME } V_{i}\end{array}$ \\
\hline 1 & 500 & 1.22 & 1.05 & 0.048 \\
2 & 400 & 1.28 & 1.06 & 0.097 \\
3 & 300 & 1.39 & 1.08 & 0.108 \\
4 & 200 & 1.64 & 1.12 & 0.130 \\
5 & 100 & $2.33 *$ & 1.22 & 0.166
\end{tabular}

*Note: $M_{5}=\mu_{5} /\left(\mu_{w} \cdot R R F\right)$

${ }^{4}$ Claridge, E.L., A method of design of graded viscosity slugs, SPE Paper 6848, 1977. 
The objective in the retention buffer calculation is to determine the amount of polymer that will be lost to retention between injector and producer. Laboratory measurements indicate a polymer retention rate of $16.34 \mathrm{Hg} / \mathrm{g} \mathrm{rock}=2.189$ $x 10^{-3} \mathrm{lb} / \mathrm{ft}^{3}$ contacted at a concentration of $500 \mathrm{ppm}$, i.e., $3.122 \times 10^{-3} \mathrm{lb} / \mathrm{ft}^{3}$. Therefore the volume of the retention buffer expressed as a fraction of pore volume contacted is

$$
V_{r}=\frac{2.189 \times 10^{-3} \mathrm{lb} / \mathrm{ft}^{3} \text { contacted }}{3.122 \times 10^{-2} \mathrm{lb} / \mathrm{ft}^{3}}=0.070 \mathrm{PV} \text { contacted }
$$

The actual amount of polymer required in a slug comprising segments $V_{r}, V_{1}, \ldots, V_{5}$ (see Figure 53 ) is obtained from the volume of pore space that will be contacted by the slug. For each quarter five-spot having area $217,800 \mathrm{ft}^{2}$, pay thickness 50 feet, porosity 0.19 , and an areal sweep efficiency $\mathrm{E}$ of 0.9 with $S_{\text {or }}=0.3$ gives

$$
\begin{aligned}
V_{\text {contact }} & =217,800 \mathrm{ft}^{2} \times 50 \mathrm{ft} \times 0.19 \times \mathrm{E} \times\left(1-\mathrm{S}_{\text {or }}\right) \\
& =1.304 \times 10^{6} \mathrm{ft}^{3}
\end{aligned}
$$

The resulting polymer requirements are listed in Table 22 on a quarter five-spot basis. Assuming 18 quarter five-spots will be contacted, the total mass of polymer required to flood the pilot area is $18 \times 1.406 \times 10^{4} 1 \mathrm{~b}=2.53 \times 10^{5} \mathrm{Ib}$ active weight.

TABLE 22

\begin{tabular}{|c|c|c|c|c|c|c|}
\hline SEGMENT & $\begin{array}{l}\text { FRACTION OF } \\
\text { VCONTACT }\end{array}$ & $\begin{array}{l}\text { VOLUME } \\
\left(\mathrm{ET}^{3}\right)\end{array}$ & $\begin{array}{c}\text { CONCENTRATION } \\
\text { (ppm) }\end{array}$ & $\begin{array}{c}\text { MASS } \\
\text { POLYME }\end{array}$ & & $\begin{array}{l}F \\
(L B)\end{array}$ \\
\hline$v_{r}$ & .070 & 91,247 & 500 & 2.849 & $x$ & $10^{3}$ \\
\hline$v_{1}$ & .048 & 62,570 & 500 & 1.953 & $x$ & $10^{3}$ \\
\hline$v_{2}$ & .097 & 126,443 & 400 & 3.159 & $x$ & $10^{3}$ \\
\hline$v_{3}$ & .108 & 140,782 & 300 & 2.637 & $x$ & $10^{3}$ \\
\hline$v_{4}$ & .130 & 169,459 & 200 & 2.117 & $x$ & $10^{3}$ \\
\hline$v_{5}$ & .166 & 216,386 & 100 & $1.351 \mathrm{z}$ & $x$ & $10^{3}$ \\
\hline TOTAL & .619 & 806,887 & -- & 1.406 ; & $x$ & $10^{4}$ \\
\hline
\end{tabular}

POLYMER REQUIREMENTS FOR EACH STAGE IN A

$$
\text { QUARTER FIVE-SPOT }
$$




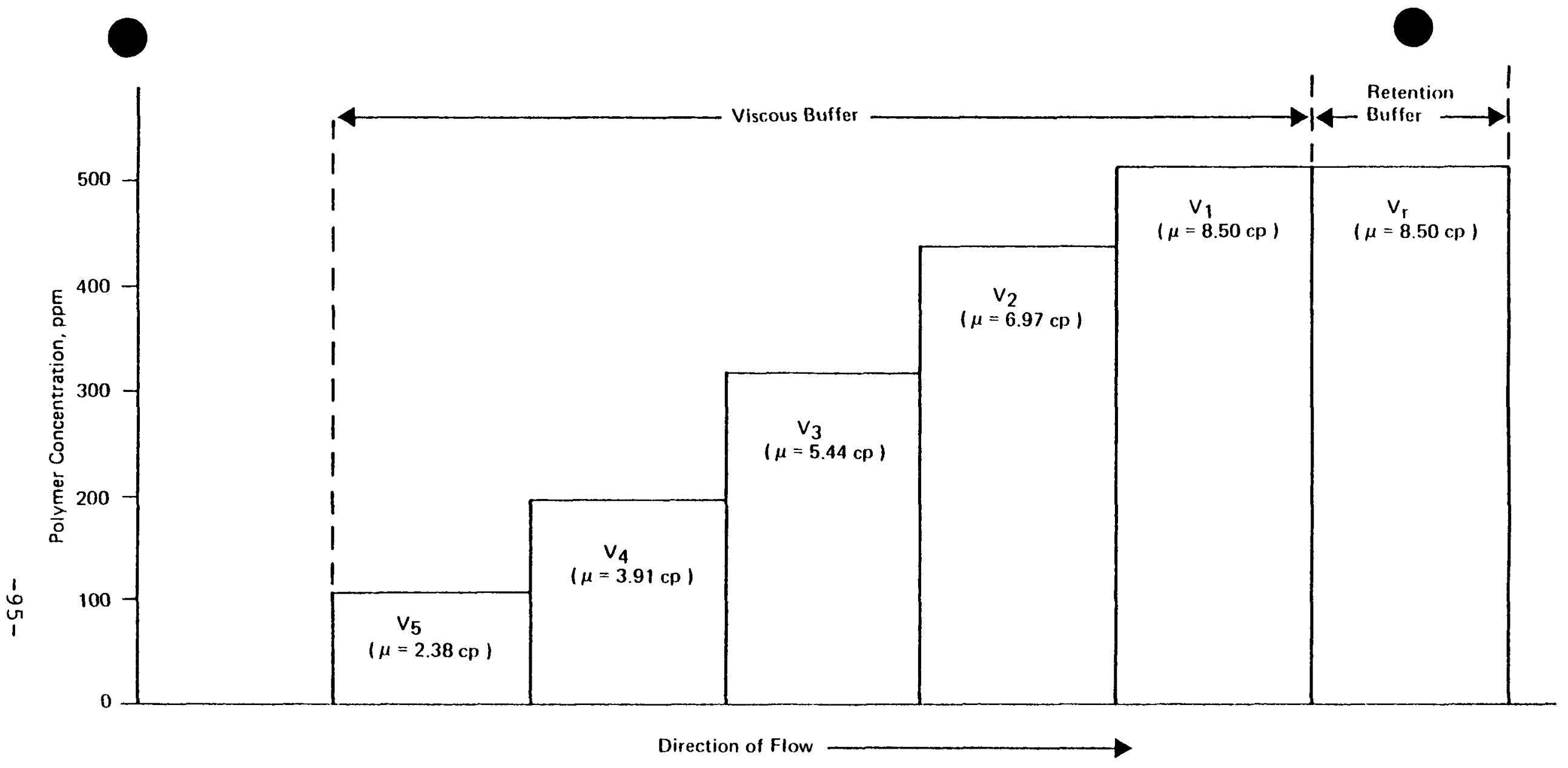

Figure 53. Schematic of polymer slug stages. 
○

○

$-96-$ 


\section{SECTION FOUR}

\section{LABORATORY TESTING AND EVALUATION}

In addition to the polymer selection program, the project team performed a set of laboratory tests to determine such rock and fluid properties as relative permeabilities, capillary pressure, and the susceptibility of polymer to biological degradation. A quality control program was developed to ensure consistency of the chemicals used during the pilot flood.

\subsection{Relative Permeabilities}

Both Energy Resources and its subcontractor Elf-Aquitaine measured the relative permeabilites of cores from well 10-5 to oil and water. Elf-Aquitaine used the steady-state method to arrive at the relative permeabilities and corresponding fractional flow listed in Table 23 . These curves are plotted in Figures 54 through 56 .

Energy Resources used the dynamic method of Johnson, Bossler, and Naumann.l These data, plotted in Figure 57 , were obtained by unsteady displacement of formation fluids (crude and brine) from reservoir cores by river water at the reservoir temperature, $95^{\circ} \pm 2^{\circ} \mathrm{F}$. The plugs ( 2 inches in diameter and 3 inches in length) were taken perpendicular to the axis of the core from well $10-5$ and were therefore oriented approximately parallel to the bedding plane of the sand, whereas the plugs used by Elf-Aquitaine were perpendicular to the bedding plane. The displacement tests plotted in Figure 57 were conducted at a scaled flow rate of about $10 \mathrm{ft} / \mathrm{day}$ to ensure negligible capillary pressure gradients and end effects.

The endpoint saturation and relative permeabilities for the Elf-Aquitaine and Energy Resources measurements are compared in Table 24. The two sets of curves are consistent in several respects. First, the residual oil saturation is high - at least 30 percent in both cases. Both curves show a low relative permeability to oil at water saturations above 60 percent, a feature that may help explain the high watercuts experienced in the field to date. Both curves also show a maximum less than 50 percent, typical of waterwet sands. There are, however, two notable differences in

\footnotetext{
${ }^{1}$ Johnson, E.F., Bossler, D.P., and Naumann, V.O. (1959), Calculation of relative permeabilities from displacement experiments, Trans. AIME 216:370.
} 
TabLE 23

RELATIVE PERIEABILITY NEASUREMENTS ON RUDULPH 5 , LEVEL 2293', AS MEASURED BY ELF-AQUITAINE, AUGUST 1979

\begin{tabular}{|c|c|c|c|c|}
\hline$s_{W}$ & $k_{r w}$ & $k_{r o}$ & \multicolumn{2}{|c|}{$k_{r w} / k_{r o}$} \\
\hline 0.10 & 0. & 1. & 0 & 0 \\
\hline 0.20 & 0.004 & 0.870 & 0.031 & 0.00460 \\
\hline U. 25 & 0.008 & 0.722 & 0.073 & 0.011 \\
\hline 0.30 & 0.013 & 0.572 & 0.138 & 0.0227 \\
\hline ט.3 & $\cup . \cup 17$ & 0.413 & 0.225 & 0.412 \\
\hline 0.40 & 0.022 & $0 .<50$ & 0.333 & 0.0880 \\
\hline U. & 0.033 & 0.178 & 0.567 & 0.185 \\
\hline U. כu & 0.044 & 0.105 & 0.747 & 0.419 \\
\hline 0.55 & 0.055 & 0.055 & 0.876 & 1.000 \\
\hline 0.00 & 0.073 & 0.015 & 0.972 & 4.867 \\
\hline 0.65 & 0.092 & 0.006 & 0.991 & 10.33 \\
\hline 0.70 & 0.110 & u. & 1. & V \\
\hline
\end{tabular}




\section{ERCO}

ENERGY RESOURCES CO. INC.

- 35 Alewire 3rook arkinay

Amoricge. Nassacrusetis $02^{`} 38$
DATE August IU, IY/y

3Y Elf-Aquitaine

SAMP! $\equiv V C$
COMPANY ERCO

=ISLO Storms Pool
LEASE Rudolph Sch. Com

COUNTY White
VELL VO 5

STATE Illinors

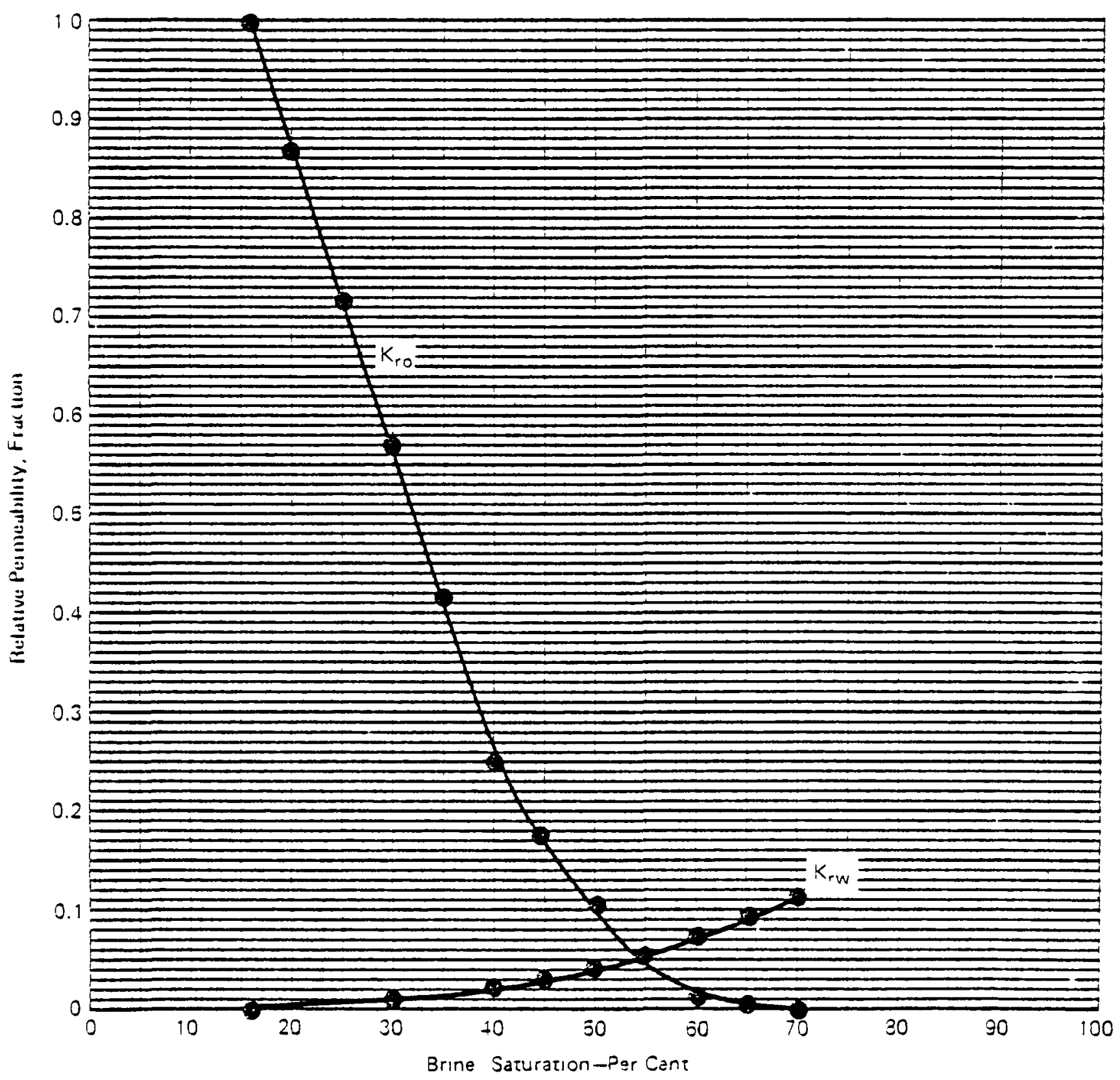

Figure 54. RELATIVE PERMEABILITIES vs. WATER SATURATION.

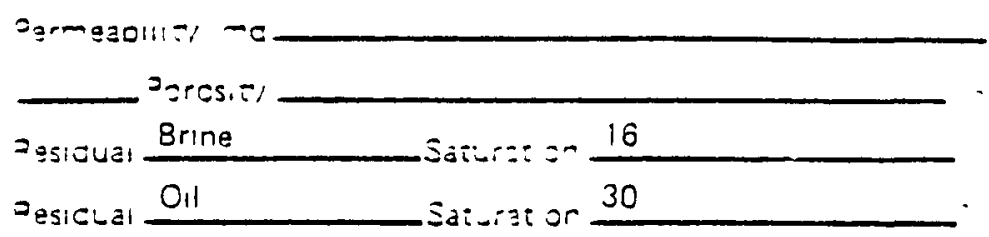




\section{ERCO}

ENERGY RESOURCES CO. INC.

i35 diewire 3rook J arkivay

Camoriage, Vassacrusatts 02138

SOMPANY ERCO

=IELD Storms Pool
LEASE Rudoiph Sch. Com. COUNTr White

$$
\text { SAMVIE VO. }
$$

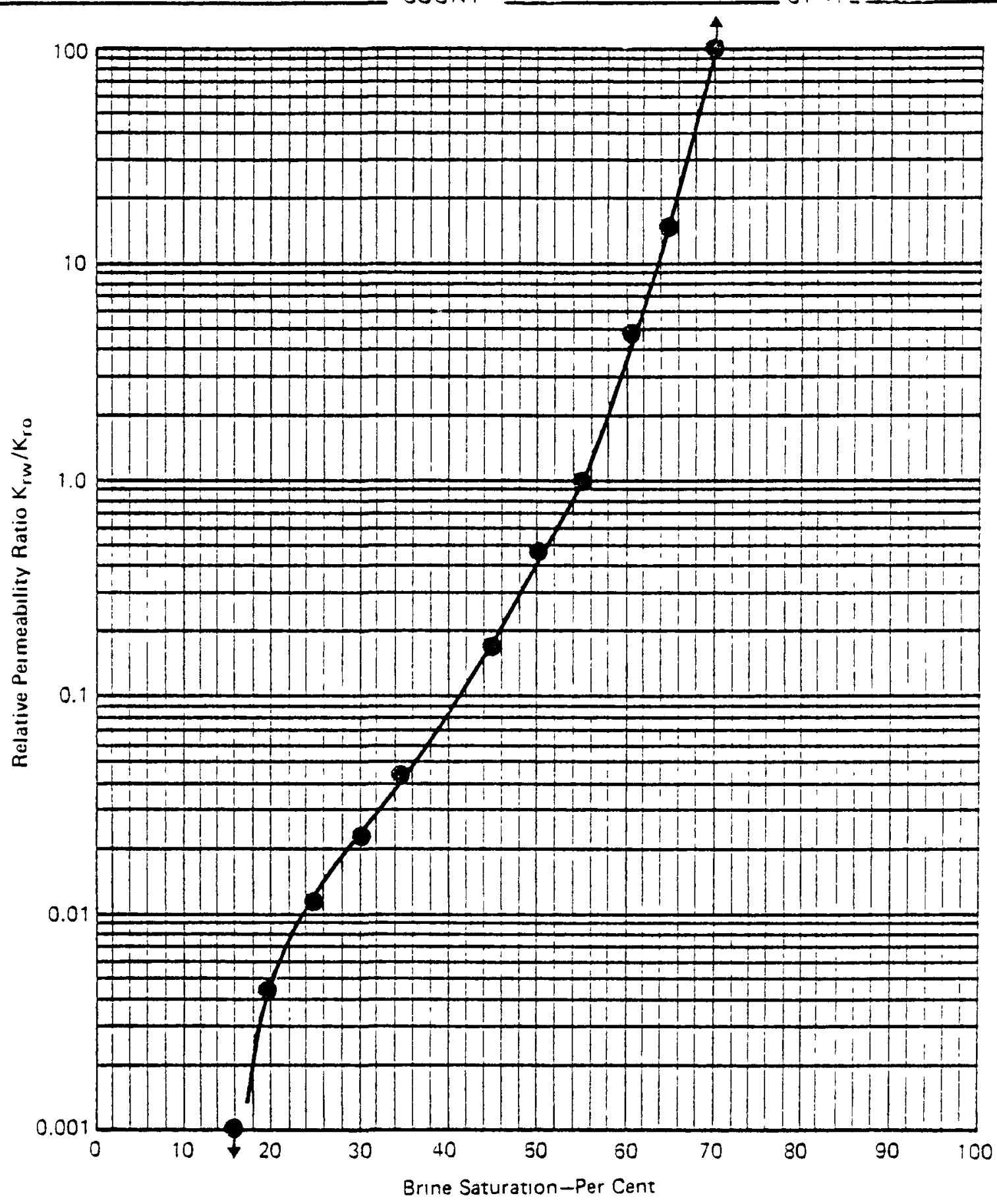

Figure 55. RELATIVE PERMEABILITY RATIO vs. SATURATION

\section{Yermec Steady-State}

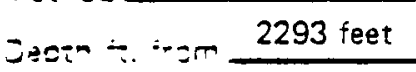

$=z-\operatorname{at} \operatorname{sen}$ Waltersburg

シミツンコくる

$$
\begin{aligned}
& \text { ogrmeзоиiт, } \rightarrow c \\
& \text { —בresial } \\
& \text { Pesicual Brine } \\
& \text { zesicual Oil } \\
& \text { satirs: sn } 16 \\
& \text { Eaturzor } 30 \\
& -100-
\end{aligned}
$$




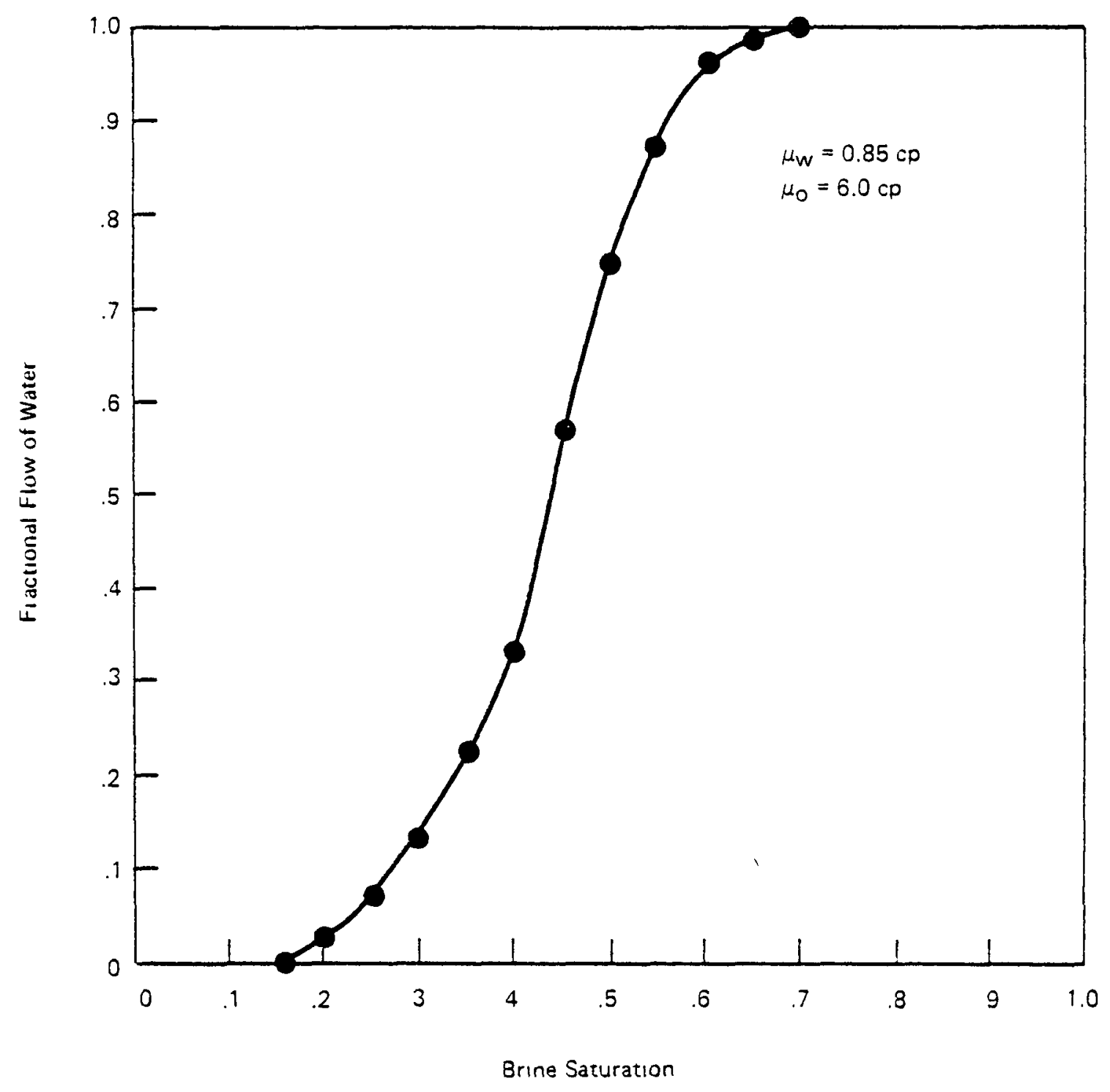

Storms Pool, Rudolph 5

White County, Illinois

Measured by Elf-Aquitaıne, Inc.

10 August 1979

Figure 56. Fractional flow of water vs. brine saturation at Well 10-5, as measured by Elf-Aquitaine.

$$
-101-
$$


ERCO

BNERGY RESOURCES CO. INC.

185 dlewife 3rcox Parkway

Camoncge, Massaciusers 02:38

COMPANY

LEASE_Rudolph

FIELD

Storms Pool
COUNTY White
3Y'Energy Resources Co. Inc.

SAMPLENO. CA62/OY7

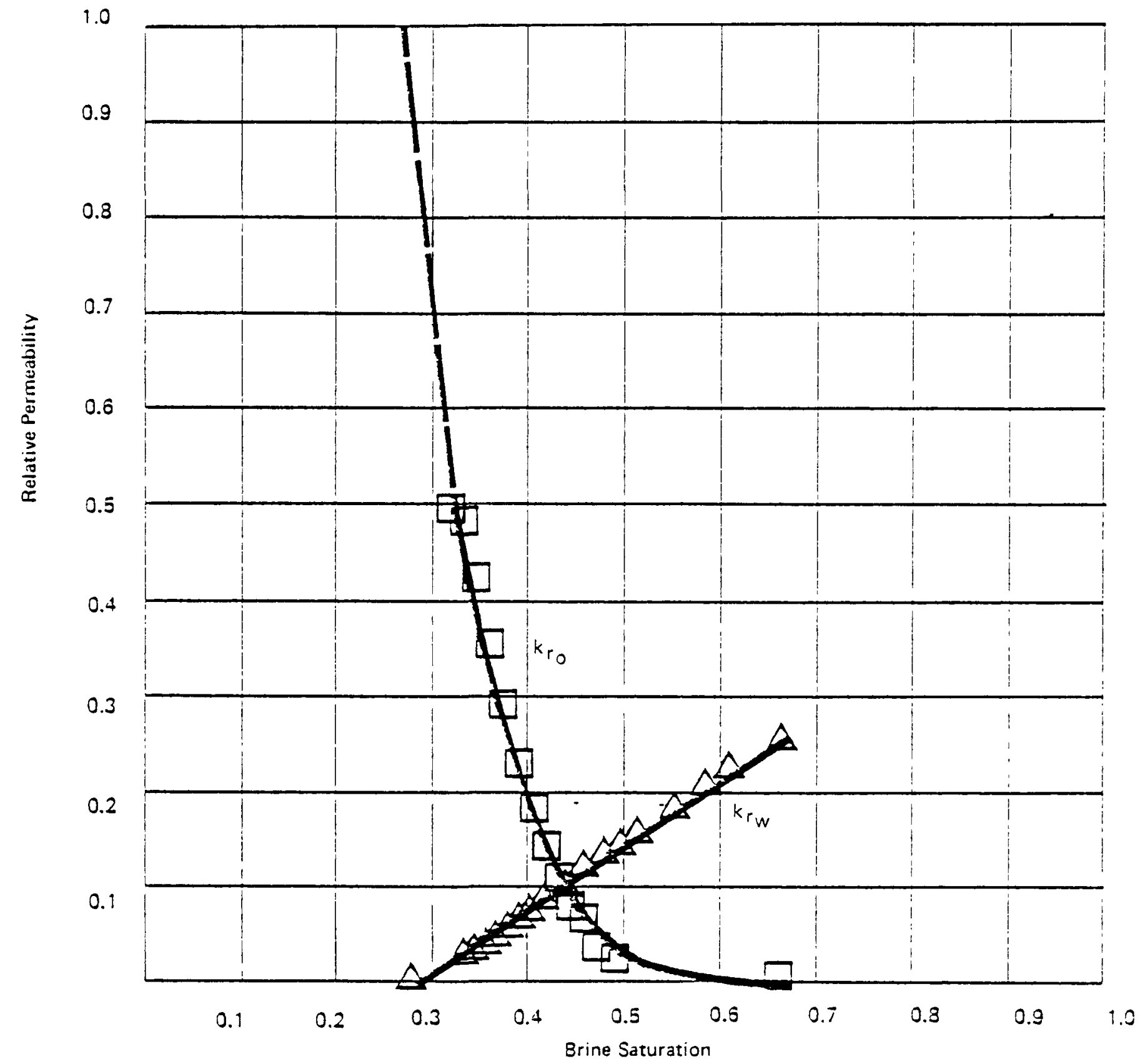

Figure 57. Relative permeability vs. water saturation.

ilences Transient

Deots -. :-om $2284 \mathrm{ft}$.

:0

Formation Waltersburg
WELL YO. 10.5

STATE

\section{Illinols}


TABLE 24

COMPARISON OF ENDPOINT SATURATIONS AND RELATIVE PERHEABILITIES AS MEASUREL BY ENEKGY RESOURCES AND ELF-ÄQUI'TAINE

\begin{tabular}{|c|c|c|c|c|}
\hline LABORATORY & sorw & $S_{\text {wir }}$ & $\mathrm{k}_{\mathrm{ro}}^{\max }$ & $k_{r w}^{\max }$ \\
\hline Energy Kesources & 0.336 & 0.248 & 0.495 & 0.250 \\
\hline Elf-Aquitaine & 0.30 & 0.160 & 1.0 & 0.110 \\
\hline
\end{tabular}

the curves. تigure 53 shows an irreducible water saturation less than 20 percent whereas that in Figure 57 is greater trian 25 percent. Also, the intersection of the oil and water curves occurs to the right of 50 percent in Figure 53 but to tne lert in Figure 57 . These features in combination inalcate that the reservoir rock is sligntly water-wet or of internealate wettability.

The total relative mobilities, expressed in reciprocal centipoises, are plotted in Figure 58 for the two sets of relative permeabilities measured. The total relative mobility is defined as the sum of the relative mobilities to oil and water, i.e.,

$$
\lambda_{T}=\frac{k_{r o}}{\mu O} \quad \frac{k_{r w}}{\mu w}
$$

The values $\mu_{0}=6.0 \mathrm{cP}, \mu_{\mathrm{W}}=0.85 \mathrm{cp}$ are assumed. These reciprocal mobility curves are typical in that the total relative mobility of the oil-water bank decreases to a minimum immediately after breakthrough and gradually increases with an increase in water saturation. This direction is the same for a polymer flood in which, for a constant viscosity (or concentration) folymer slug, the mobility ratio increases from a lower value prior to breakthrough to a maximum in the nedium saturation range.

For tne pilot polymer flood in the storms Pool, the ininimum total relative nobility can be used to check the polymer slug design. Ine minimum total relative mobility in tne lowest curve or Figure 58 is $0.057 \mathrm{cp}^{-1}$. At a water saturation of 45 percent, corresponding to this iiininum total relative mobility, the nobility ratio for an 


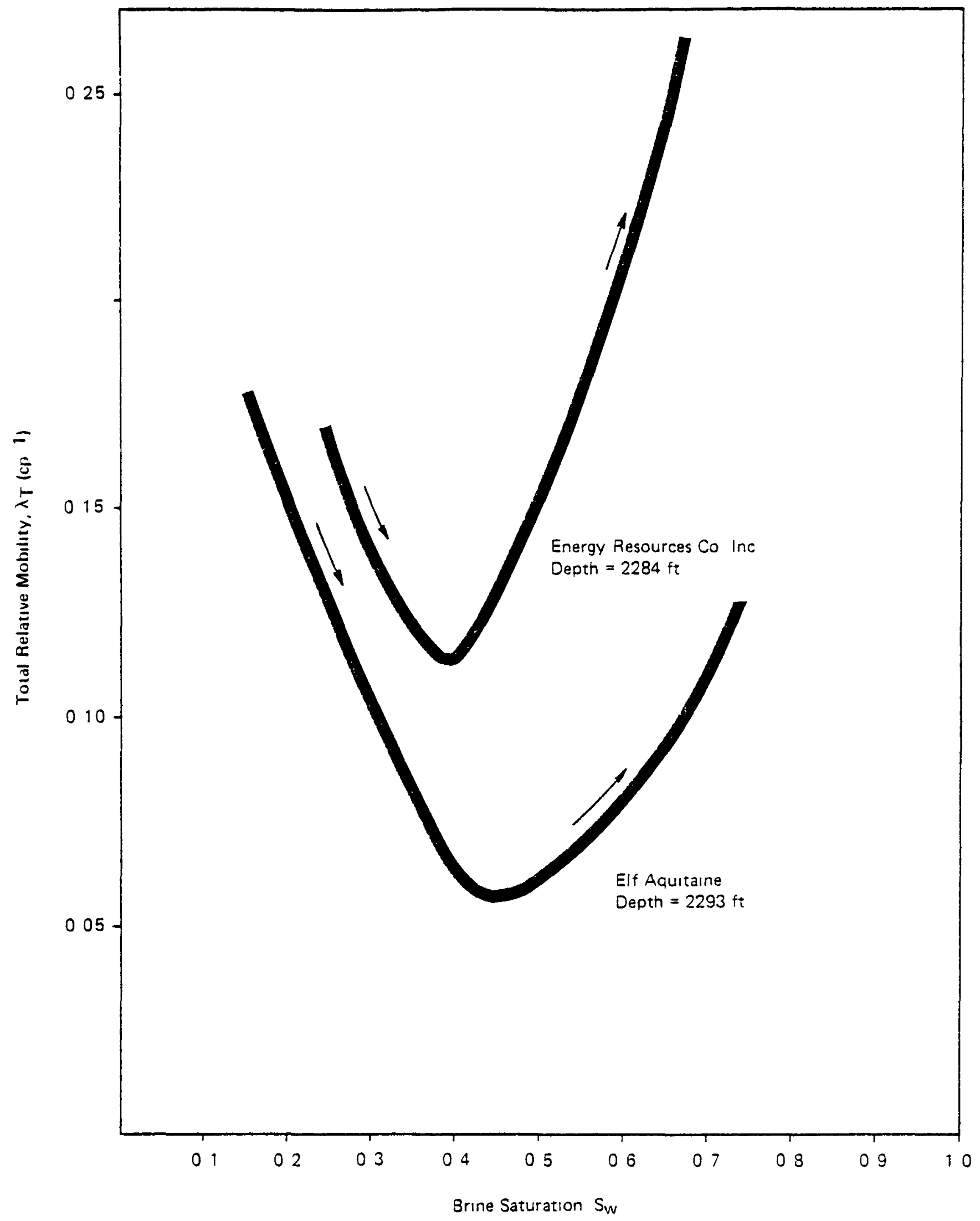

Figure 58. Comparison of total relative mobility versus saturation for curves measured by Energy Resources and Elf Aquitaine. 
8.5 cp slug is 0.045 . At flood-out, i.e. residual oil saturation and the end of a graded slug, the mobility ratio is still Eavorable at 0.046 .

\subsection{Capillary Pressure}

Capillary pressure curves are shown in Figures 59 and 60. Figure 59 illustrates a typical air drainage curve in which the irreducible brine saturation is approximately 12 percent. Tnis figure corresponas reasonably well with some of the residual saturations of the dynamic displacenent experinents. The invivition and urainage curves of a reservoir cruaje-orine system in the same core are illustrated in Figure ou.

\section{3 wicroblology of the storms pool}

bacteria in oil reservolrs pose several potential srovlens in the design of a polymer flood. H.S rormed by sulfate reaucing bacteria may combine with iron in water, forming a colloidal suspension which will complex with suspended particulate matter, including bacteria. This can cause clogging wnen the water is injected into the oi reservoir. Biopolymers are a prime nutrient source for Dacteria, ana inicrobial attack can alter the viscosity and gel properties of polymer-water solutions. Although biocides such as formaldehyde and paraformaldehyde have been used in initial concentrations as high as 10 percent, they often fail to inhibit microbial growth completely because effective concentrations nay be much lower in situ. To understana the inicrobiological community associated with the Storns pool, Energy Resources performed a taxonomic screen of the microflora from the site's river and formation waters. The anaerobic sulfate reaucing bacteria associated with core sediments were also quantified, and the 10 most prevalent bacterial colony types from each class of sample were isolated and characterized. The ability for isolates to subsist on hydrocaroons, biopolymer, and a polyacrylamide was also determined.

\subsubsection{Materials and wethoas}

water samples were obtained near tne intake below the river pumps on the Little waoasn River and from the waltersvury tormation at Well b-16 during the last week of september 1978. 
ERCO

ENERGY RESOURCES CO. INC.

185 Alewite Brook Parkway

Cambridge, Massachuserts 02138
DATE $\frac{10 / 11 / 79}{\text { JBE }}$

SAMPLE VO. CA81,EO05
COMPANY

FIELD Storms Pool
LEASE Rudolph

COUNTY White
WELL VO $10-5$

STATE

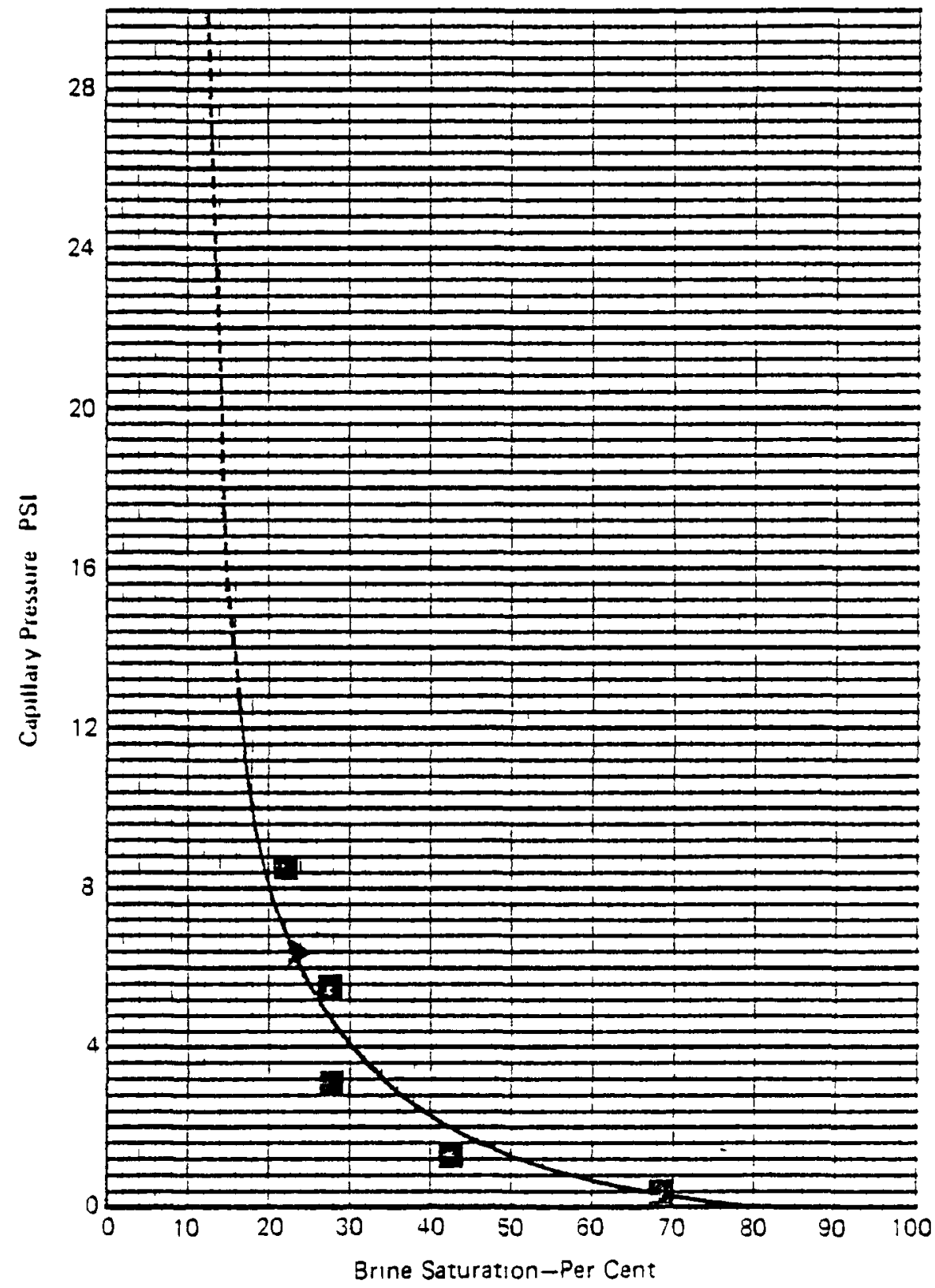

Figure 59 CAPILLARY PRESSURE vS. SATURAT'ON

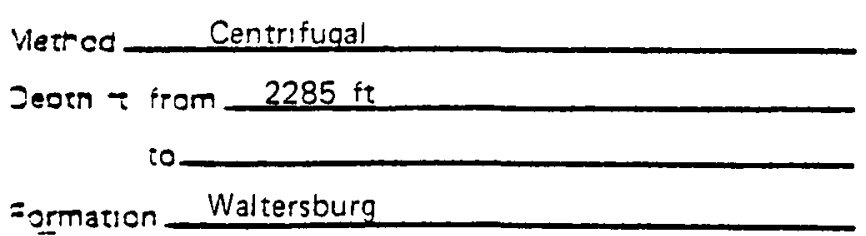

ogrmeadite, ad $\quad 375$ md Abs Prosis $237 \%$ Pesicual Saturat on

Zesidual Saturzitor 
ERCO

ENEAGY RESOURCES CO. INC.

185 Alewife Brook Parkway

Cambridge, Massaciusers 02138
CATE $\quad 10 / 18 / 79$

BY_ JBE

SAMPLE NO.CA81/EQ05
COMPANY

FIELD Storms Pool
LEASE Rudolph

COUNTY White
WE:L NO. $10 \cdot 5$

STATE Carmi, lltinois

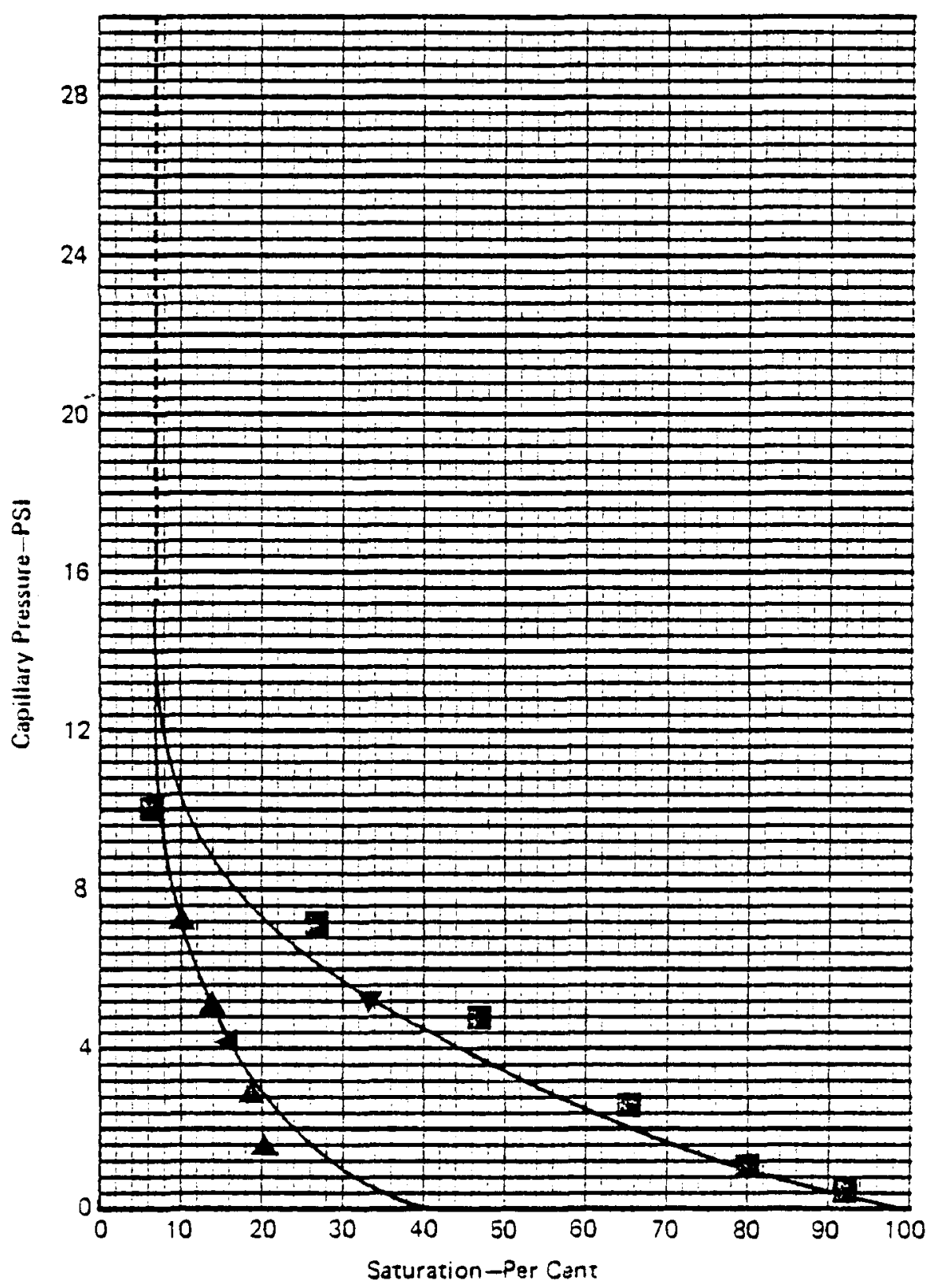

Figure 60. CAPILLARY PRESSURE vs. SATURATION.

Wernce Centrifugal

Dectn -. irom $2285 \mathrm{ft}$.

:0

Formar: cn Waltersburg
Permezoilite. nd 375 md

Abs Pscosity $23.7 \%$

Aesidual _. Saturation Saruration \%

Residual 


\section{Herobic and Anaerobic Heterotrophic Population}

water samples from each source were membrane-íiltered through 0.45-micron Nuclepore membranes (Nuclepore Corp., rieasanton, California) to count the colony-forming units (CFU) per til of sample. The following dilution series was filtered in triplicate: $100 \mathrm{ml}$ of sample, $10 \mathrm{ml}$ of sample, lu ml of $1: 10$ dilution, $10 \mathrm{ml}$ of $1: 100$ dilution, and $10 \mathrm{ml}$ of a 1:1,000 dilution. One melibrane of each dilution was then placed on each of the following nutrient media:

1. ivutrient agar on 50-mm plate.

L. API agar plate preparea accoraing to allrea. 2 Sulfate reducing colonies become black on this inedium.

3. Weaia-tree 5u-mm plates. Menbranes were tnen overlaid with API agar to exclude air and therefore select anaerobes.

Nutrient agar and aerobic API plates were incubated aerobically at $20^{\circ} \mathrm{C}$ for 7 ays. Anaerooic ifpl plates were placed in a sBL 3 las $\mathrm{Pak}$ system and incubated anaerobically in an atmosphere of $\mathrm{H}_{2}$ and $\mathrm{CO}_{2}$ for 0 weeks, being observed periodically curing that period. At the ena of the incubation period, sulfate reducing $\mathrm{CFU} / \mathrm{ml}$ (black colonies) and total anaerobic CFU/ml were counted.

\section{Anaerobic Sulfate Reducers in Core Samples}

A similar procedure was followed to quantify the anaerobic sulfate reducers in the formation. Two core samples from riell $10-5$ at 2,272 feet subsea were cracked open aná the interior sections removed aseptically into a sterile mortar. They were ground with a mortar and pestle to a fine sanay consistency. The following procedure was performed in quadruplicate: $1 \mathrm{~g}$ of sample was transferred to a tube containing $y \mathrm{ml}$ API broth. This was stoppered and flowed back and Forth four times to $\mathrm{mix}$ the inoculum. One in I from this tube was then transferred to a second tuid of $y$ inl $A P I$ ayar and mixed as oefure. The serial transfer was continued until a dilution of 1:10,000 was reached. The tudes were then capped and incuibated at $20^{\circ} \mathrm{C}$ over a period of 5 
weeks. The tubes were checked each week for intense black colonies indicating suliate reducing bacteria.

Isolation and Maintenance of Isolates

To isolate a representative bacterial population from the water samples, 10 representative colonies from each master plate were restreaked onto nutrient argar and API agar ilates, then incubated for 3 days at $20^{\circ} \mathrm{C}$. They were then transierred to $5^{\circ} \mathrm{C}$ for storage for 2 weeks. Single colonies from each of the nutrient and API agar plates were then streaked onto nutrient and API agar slants, respectively, and incubated for 3 more days at $20^{\circ} \mathrm{C}$. A second set of nutrient ayar and API plates was restreaied ayain rrom these slants to obtain pure cultures. Luring the experimental verioa, the isolates were restreased onto fresh slants three times at 2 -week intervals to maintain the freshness of the cultures. All cultures were malntained at $20^{\circ} \mathrm{C}$ ano all microscopic and physiological tests were made with 48 - to $7 \%$-hour-old cultures.

\section{Taxonomic Identification of the Isolates}

The isolates were screened taxonomically according to the procedures delineated in Energy Resources' taxonomy manual. The following tests were performed on each isolate: Gram sta:n, cell motility and norphology, colony morphology, pnysiolcical tests for catalase, oxidase and urease activity, carbohyo: ate utilization, gelatin hydrolysis, cellulose aegradat on, nitrate reduction, $0 / 129$ (vibriostat) sensitivity, aru citrate reduction. Fhase microscopy of all organisns was perforned using a Zeiss universal-phase epifluorescence scope.

\section{Screen for Nutritional Capabilities}

'Io assess the capability of each of the isolates to grow on polyacrylamide $B$, biopolymer $G 2$, and a model hydrocarbon mixture (11.1 percent each of $\mathrm{C}_{12}-\mathrm{C}_{22}$ n-alkanes) the following procedure was used: the test polymer or model nydrocarvon mixture absorbed onto 10 percent silica gel was mixed lo percent weignt-to-volume with sterilizea irakula and F'innerty's 4 river mecia, plus 1.5 percent agar. Thorougn unixing $w$ s accomplisheu by sonicating the mixture 20 minutes in sterile 1-liter polypropylene bottles and vortexing for 5

"Hakula, R., and Finnerty, W.R. (1969), Nicrobial assiullation of hydrocarbons. I. Fatty acids derived from normal alkanes, J. Bacteriol. 95:2102-2107. 
ininutes at high speed. 'l'his proceciure was required for homogenizing tne medium plus the nutrient source mixture. The medla were then poured into $100-\mathrm{mm}$ petri plates. Each isolate was streased in duplicate onto each of the tnree inedia. The isolates were also streaked onto Makula and Einnerty's river media and 1 b percent agar without the supplemental polymer or hyarocarbon source to check for the utilization of agar as a sole carbon source. All plates were incubated at $20^{\circ} \mathrm{C}$ for 10 aays. Isolates growing on test media were transferred from the initial test plate and restreaked onto a second set of plates to ensure that growti on the primary plate was not due to nutrient carry-over. Isolates growing on test nutrients but not on unsupplemented agar were considered confirmea utilizers of the test carbon sources.

\subsubsection{Results}

\section{Quantification of Heterotropnic Bacterial Cominunity}

suantitative data for aerooic and anaerobic heterotrophs are given in Table 25. Aerobic heterotrophs in the sampled formation water, river water, and sediment were numerically signiricant in all three sources. Titers ranged from 60 $\mathrm{CH} \cup / \mathrm{ml}$ in the seaiment and formation water samples to 450 $C F i / n l$ in tie river water sample. Aerobes are considereu to we signiticant at titers yreater than or equal to $9 \mathrm{CFU} / \mathrm{ml}$. 'lne anaerobic population was significant (at least 1,500 CFU/mI) in the secilment sample only.

\section{T'ABLE 25}

COLONY-FORVIING UNI'SS OF BACTERIA IN EORIVIATIUIN WATER, RIVER HZU AWD SEDIMENT

\begin{tabular}{lccc}
\hline & $\begin{array}{c}\text { RIVER } \\
\text { WATER } \\
(\text { CFU } / \mathrm{mI})\end{array}$ & $\begin{array}{c}\text { SEDIMEIT } \\
(\text { CFU } / \mathrm{ml})\end{array}$ & $\begin{array}{c}\text { FORMATIUN } \\
\text { (NATER } \\
(\text { CFU } / \mathrm{ml})\end{array}$ \\
\hline $\begin{array}{l}\text { Rerobes } \\
\begin{array}{l}\text { Facultative } \\
\text { anaerobes }\end{array}\end{array}$ & 450 & $100-150$ & 70 \\
$\begin{array}{l}\text { Strict anaerobes } \\
\text { Sulfate reducers }\end{array}$ & 0 & $13,000-20,000$ & 93 \\
\hline
\end{tabular}


I'axonomy oI Salipled Formation and River Water Bacteria

Ine taxonoiny of the formation and river water samples ('table 20) showed a typical cross section of aerobic bacteria associated with soil and water. Tnree genera predominated: bacillus, pseudomonas, and Arthrobacter. Anaerobic sulfate reducers were found only in the formation water sample but constituted 40 percent of the isolates from this source. Four of the five sulfate reducing isolates were Desulfoviorio species; one was Desulfotomaculum species.

Nutritional Screen: Polymer and Hydrocarbon Utilization

Data from the nutrient screen are summarized in Table 27. Biopolymer G2 supported extensive growth but polyacrylamide $\mathrm{B}$ did not. Identification of each of the isolates showed a predominance of three taxa that are commonly associated with soil and water. Of the isolates from each of the three groups, Arthrobacter, Bacillus, and Pseudomonas, one-third to one-half were able to grow on biopolyiner G2 with 30 piril formaldehyde, and 60-100 percent were supported by the hyarocarbon mixture. Two other isolates, identified as wicrococcus and Citrobacter species, were able to utilize tne nyarocarbon mixture only. Only one isolate was able to utilize the polyacrylamide $B$. The isolate has tentatively ween identified as a micrococcus species, but such nutritional rlexluldity is unusual with this species and the isolate's laentity snoula be re-exanined.

line testing procedure used here is subject to some variation aue to the difficulty in handing the polyners in a solid form. polyacrylamide is appeared able to degrade the ayar support matrix into whicn it nad been mixed, causing the media to turn into a sticky slime which would not aủhere to the test plate after 3 or 4 aays' incubation. 'Inis condition occurrea erratically among the test plates and made it difficult and in some cases impossible to determine if growth occurred. Apparently this was not due to bacterial degradation, because the condition was originally discovered in uninoculated plates. After 4 weeks of incubation, fungal growth was observed on several of the polyacrylamide $B$ plates. The fungus may have been introduced to the plates as a contaninant or may represent part of the microflora. further investigation of this fungus is under way.

\section{3 .3 viscussion}

Ine initial screen of the isolates from river and formation samples reveals a cross section of taxonomic 
TABLE 26

STORMIS FOUL UINIT BAC'TERIAL TAXUNUMY:

PREDOMINANCE AND DISTRIBUTIUIN OF BACTLRIAL TAXA

FKUW SAMELED RIVEK AND FORMATION WATERS

A. AEROBIC HETEROTROPHS IN RIVER AND FORIAATION WATER

\begin{tabular}{llcc}
\hline & NUMBER OF & NUMBER OF & NUMBER OF \\
& ISOLATES & RIVER & FORMATION \\
TAXONOMIC & FROM TOTAL & WATER & WATER \\
GROUP & OF 39 & ISOLATES (18) & ISOLATES (21) \\
\hline
\end{tabular}

Arthrobacter

Bacillus

Pseudomonas

iicrococcus

Sporosarcina

Aerococcus

Corynedacterium 3

Elavobacter 1

"wycobacterium 1

Leuconostoc 1

Hyinomicrodiun 1

Citrodacter 1

Lactobacilius 1

Actinobacilius 1

paracoccus

$\begin{array}{ll}2 & 1 \\ 5 & 2 \\ 3 & 4 \\ 1 & 4 \\ 3 & 1 \\ 1 & 1 \\ 1 & 2 \\ 1 & - \\ - & 1 \\ - & 1 \\ 1 & - \\ - & 1 \\ - & 1 \\ - & 1 \\ - & 1\end{array}$

B. ANAEROBIC HETEROTKOPGS IN RIVER AND FORMATION WATER

\begin{tabular}{|c|c|c|c|c|c|}
\hline $\begin{array}{l}\text { TAXONOMIC } \\
\text { GROUP }\end{array}$ & $\begin{array}{l}\text { NUMBI } \\
\text { ISOLA } \\
\text { FROLI } \\
\text { OF }\end{array}$ & $\begin{array}{l}\text { RR OF } \\
\text { TES } \\
\text { TOTAL } \\
13\end{array}$ & $\begin{array}{l}\text { NUIVEER OF } \\
\text { RIVER } \\
\text { WATER } \\
\text { ISOLATES (3) }\end{array}$ & $\begin{array}{l}\text { NUMBEK OF } \\
\text { FORMATION } \\
\text { WATER } \\
\text { ISOLATES (10) }\end{array}$ & $\begin{array}{l}\text { SULFATE } \\
\text { REDIJCTION }\end{array}$ \\
\hline \multicolumn{2}{|c|}{$\frac{\text { Vibrio }}{\text { (facultative) }}$} & 5 & 3 & 2 & 0 \\
\hline \multicolumn{2}{|c|}{$\frac{\text { Bacillus }}{\text { (facultative) }}$} & 3 & 0 & 3 & $+a$ \\
\hline \multicolumn{2}{|c|}{ Desulfovibrio } & 4 & 0 & 4 & $+++b$ \\
\hline \multicolumn{2}{|c|}{ Desulfotomaculum } & 1 & $\checkmark$ & 1 & $+++b$ \\
\hline
\end{tabular}

$+a=<1 u$ percent sulfate reduction activity.

$+++\dot{D}=>90$ percent sulfate reduction activity. 
TABLE 27

NUTRITIONAL CAPABILITIES: GROWTH OF COLONIES IN BIOPOLYMER G2, COPOLYMER B, AND MODEL HYDROCARBON MIXTURE

\begin{tabular}{|c|c|c|c|}
\hline & \multicolumn{3}{|c|}{ NUMBER OF COLONIES GROWING } \\
\hline & BIOPOLYMER G2a & POLYACRYLAM IDE & $\begin{array}{l}\text { HYDROCARBON } \\
\text { MIXTURE }\end{array}$ \\
\hline Arthrobacter & 1 & 0 & 2 \\
\hline Bacillus & 4 & 0 & 7 \\
\hline Pseudomonas & 2 & 0 & 6 \\
\hline Micrococcus & 0 & 1 & 1 \\
\hline Citrobacter & 0 & 0 & 1 \\
\hline
\end{tabular}

groups comparable to previous findings on bacterial populations associated with waterflooded oil fields. $5,6,7,8$ The two water sources contain taxa which have potential to metabolize the biopolymer G2 with $300 \mathrm{ppm}$ formaldehyde, cause corrosion; and plug the formation.

The predominant isolate types were able to utilize the biopolymer G2 with 300 ppm formaldehyde as a growth medium. A formaldehyde concentration of 75 to $80 \mathrm{ppm}$ is considered necessary for effective biological control. However, extended polymer residence times in the reservoir, usually at least 110 days, coupled with variations in the system (such as preferential adsorption of highly active biocides)

5Bastin, E.S., and Gifeer, J.W. (1930), Additional data on sulfate-reducing bacteria in soils and waters of Illinois oilfields, Bull. Am. Assoc. Petrol. Geologists $14: 143-159$.

${ }^{6}$ Ginsberg-Karagicheva, T.L. (1933), Microflora of oilwaters and oil-bearing formations and biochemical processes caused by it. Bull. Am. Assoc. Petrol. Geologists $17: 52-65$.

7 Issatchenko, V. (1940), J. Bacteriol. 40:379-381.

8 zobel1, C.E. (1950), Fundamental research on occurrence and recovery of petroleum, Report of Progress for 1948-1949 (New York, Am. Petrol. Inst.). 
can result in a decrease in the actual oiocide concentration and a decrease in its effectiveness. 9 zobelilo conaucted permeability studies of various bacterial species in reservoir rock. He found that pseudomonads can permeate very finegrained sanustone and survive indefinitely. The presence of pseudomonad isolates in the formation water sample ( 83 percent of which are able to use biopolymer 62 with 300 ppin as sole carbon sourcel could reduce the efficacy of the flood if the biopolymer is not injected with sufficient concentrations of biocide.

Biopolymer-metabolizing bacteria are also present in the river water samples. Accordingly, care must be taken not to introduce these populations into the oil bearing rock where they may proliferate and become a source of similar provlems.

Sulfate reucing bacteria have been found in the samples, and tnerefore the potential for corrosion and clogging exists. However, a smaller proportion of sulfate reuucing isolates than expected was found in the two water samples. All sulfate reducing isolates were found in the Eormation water sample and seuiments, incicating a close assuciation with the oil formation and not the surface waters.

'the next logical step in studying the licrobiology of the storins puol is to determine whether the microbiological community does, in fact, adversely affect tie polymers used in the project. Preliminary experiments ar under way to determine the effect of two isolates on the viscosities of biopolymer $G 2$ under laboratory conditions. If nicrobial growth adversely affects polymer viscosity in these experiments, the next task will be to ascertain whether a similar phenomenon occurs in simulated field conditions. The third phase wil be used to develop corrective measures for any deleterious effects of the microbial community on the polymer solution.

\subsection{Quality Control Progranil}

Preliminary specifications to be usea for polymer quality control were submitted to pfizer in ilovember, 1979.

Ywyers, G.C. (1902), Paraformaldenyde resistant starch fermenting bacteria in "starch-base arilling mua," Appl. Microbiol. lu: 418-42I.

lU Zobell, C.E. (1946), Fundamental research on occurrence and recovery of petroleum, Report of Progress for 1944-ly45 (New York, Am. Petrol. Inst.). 
The quality control program planned includes testing for millipore filterability, viscosity, active weight, and formaldehyde content, as indicated in Table 28. These parameters are tentative and subject to revision after the injectivity test scheduled for January, 1980. If injectivity is extremely good more latitude might be allowed in the millipore filter ratio and absolute filterability tests. An on-site quality control $l a b$ is being designed to perform these tests and other necessary lab work.

Testing of ancillary chemicals began during November, 1979 to determine the effect of various biocides, oxygen scavengers, and chelating agents on the integrity of the polymer and its ability to function under reservoir conditions. These tests are discussed in Section Three. Two biocides will be used to allow rotation.

TABLE 28

QUALITY CONTROL PARAMETERS FOR POLYSACCHARIDE

TEST

ACCEPTABLE RANGE FREQUENCY

Filterability in 1.2-micron

Filter

Millipore filter ratio

Total Filtration time

$1.0-1.3$ every batch

1000 sec/liter max. every batch

Viscosity at $500 \mathrm{ppm}$

In Wabash River water

In Pfizer standard water

$7-9 \mathrm{cp}$

every batch

$9-11 \mathrm{cp}$

every batch

Active Content

Viscosity method

$2.6 \%$ minimum

every batch

Toal carbohydrate method

2. $5 \%$ minimum

as needed

Formaldehyde Content

$2000 \mathrm{ppm}$

as needed 
0 


\section{WELL PREPARATION}

Reconditioning and restimulation of the 10 original wells in the pilot area began in November, 1978 and was completed in the period covered by this annual report. In addition the new Well 10-5, drilled in 1978, was completed and prepared for production. Three wells, one injector and two producers, were reconditioned in 1978. Well 10-3 was cleaned, acidized, and tested; Wells 9-1 and 9-4 were both cleaned and tested for production rate. These workovers are reported in the first annual report. The remaining wells were worked on in 1979.

\subsection{The New Well 10-5}

In 1978 an additional well was drilled in the center of Tract 10 to recover a complete fresh core from the Waltersburg sand and for logging and observation during pre-injection testing. This well is only 466 feet from the nearest injectors and producers (Figure 61), whereas normal well spacing in the pattern is 10 acres or 660 feet between injector and producer. The new well will therefore receive a stronger, more interpretable response in pressure tests and will play an important role in tracer and polymer injection to check the progress of chemicals.

From May 25 to June 1, 1979, Well 10-5 was circulated clean to 2306 feet subsurface and perforated with 60 holes (approximately two holes per foot) between 2267 and 2297 feet subsurface ( 1865 to 1895 feet subsea). Figure 62 is the gamma ray-neutron log which was run in conjunction with the perforation job. This well was perforated only in the top 30 feet of the Waltersburg formation in hope of avoiding the zone of high water saturation which lies just below the oil zone. The well was acidized on June 7,1979 with 1000 gallons of Halliburton MCA and 1000 gallons of 5 percent HCl. A swab test produced $3 \mathrm{bbl} / \mathrm{hr}$ of formation water with a trace of oil. Rods and tubing were run, and the well is currently ready for production.

\subsection{Injection Well Workovers}

Five of the six injection wells for this pilot were reconditioned during the period covered by this report. The sixth, Well 10-3, was completed in 1978 . 


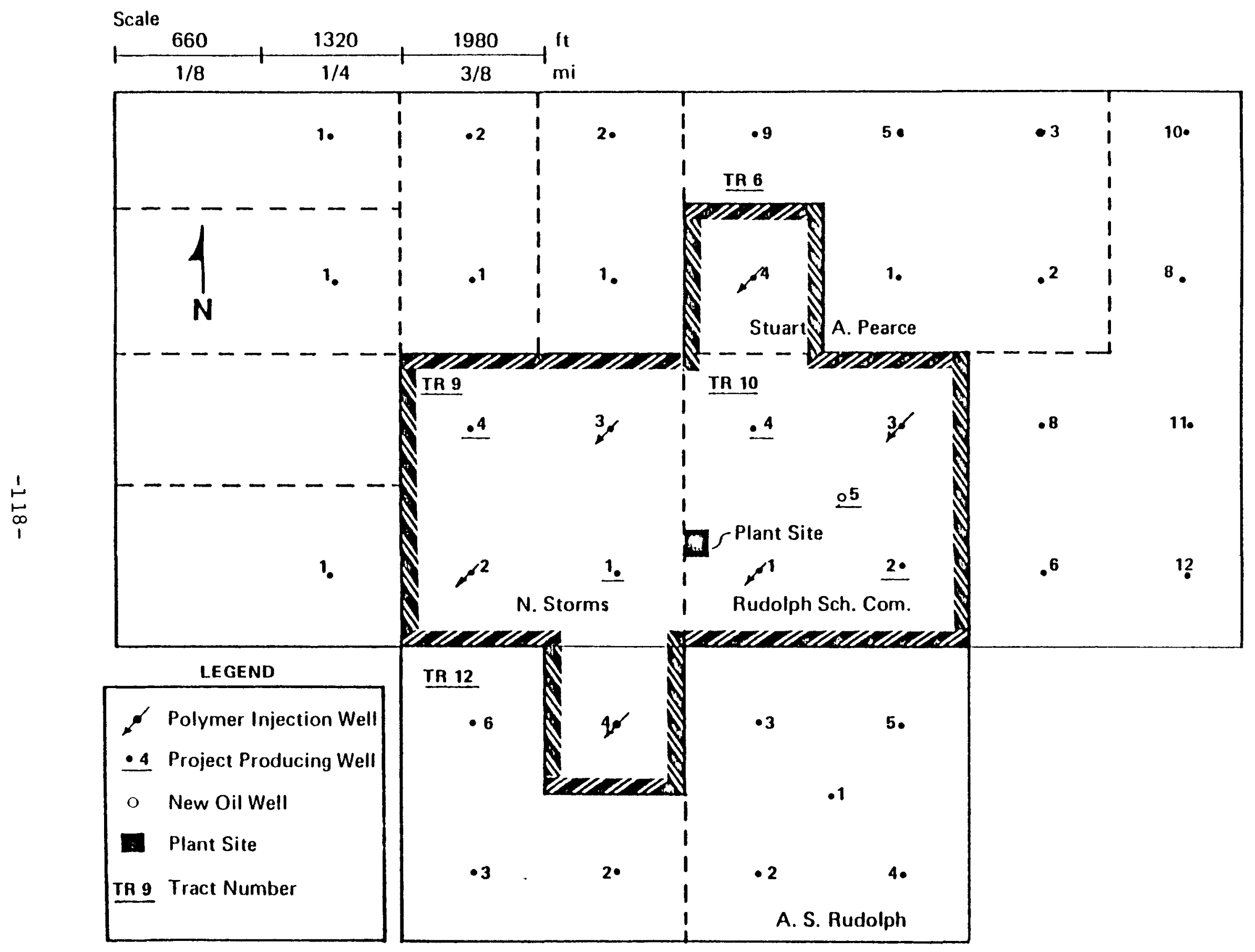

Figure 61. Layout of Storms Pool pilot facilities. 

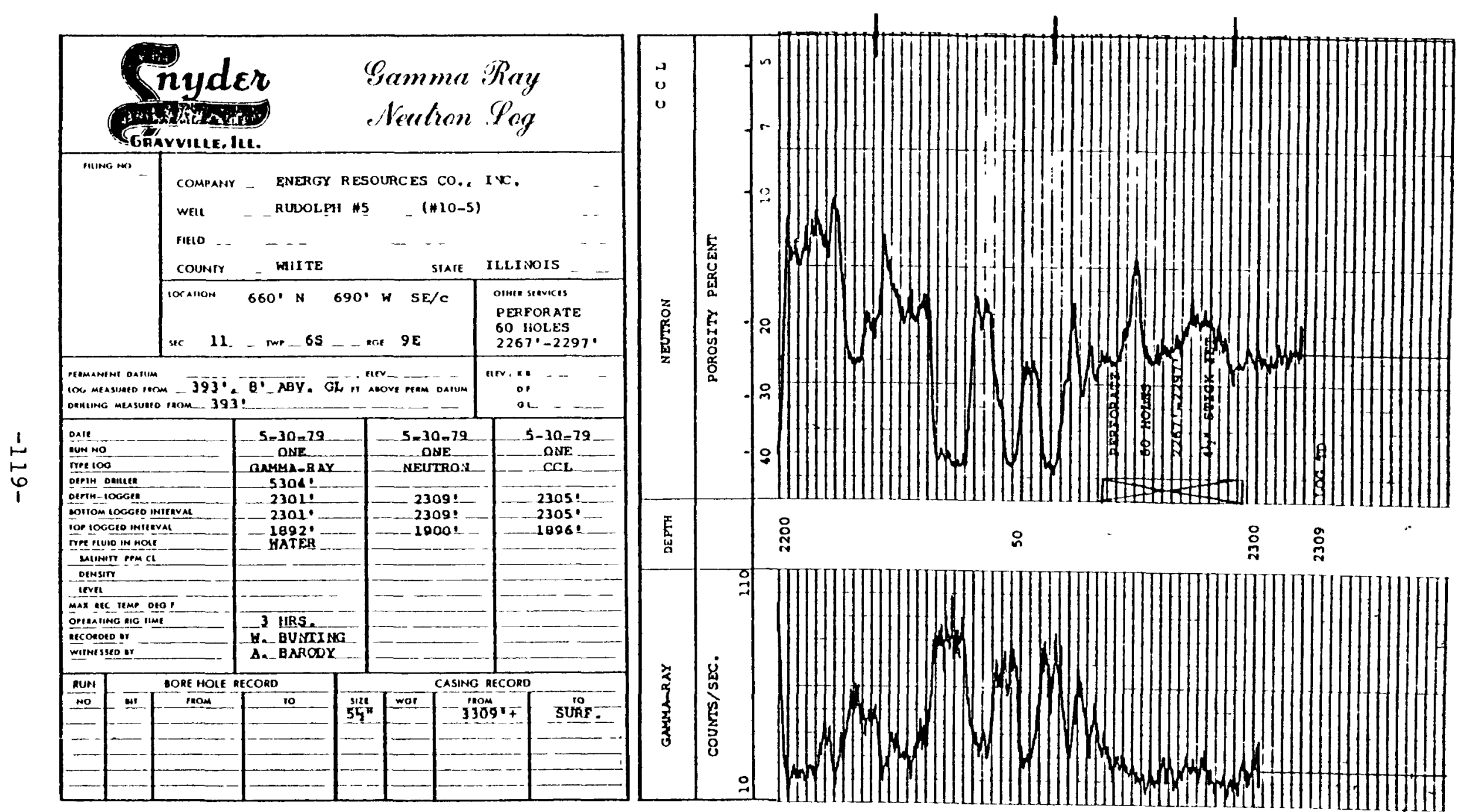

Figure 62. Gamma Ray Neutron Log, Well 10--5. 
The reservoir engineering report for the project generated some questions regarding the thickness of the oil-saturated sand. Logs of well 10-5 had indicated the presence of oil deeper than the originally assuned oil-water contact at 1890 feet subsea. Well 10-l therefore was deepened to 2310 feet subsurface level (1ylo feet subsea) and a Schlumberger dual induction laterolog was run. The moderately high resistivity below 2290 feet subsurface recorded by this log (Figure 63) was difficult to interpret in light of the large volumes of fresh water injected tnrough this well during the waterflood. The low resistivity recorded in the completion interval (2272-2282 feet subsurface) suygests that the shot hole is quite large, extending off-scale of the medium-range induction log.

well 1u-1 was then acidized with 500 gallons of 5 percent $\mathrm{HCl}$ which was allowed to stay in the shot hole, followed by 1500 gallons of 15 percent Halliburton FE acid under pressure. The acid was pumped in at $2 \mathrm{gal} / \mathrm{min}$ and was followed by $3 \mathrm{bol} / \mathrm{in}$ in of formation water at $100 \mathrm{psig}$. Two-inch plastic coated tubing and a packer were set in the hole at 2161 feet subsurface, and the well is now hooked up for injection.

well 9-2 was circulated clean to a total depth of 2283 feet subsurface ( 1880 feet subsea) and acidized with 1500 gallons of 15 percent Halliburton FE acid. Plastic coated tubing was run in the well and a packer set at 2163 feet subsurface.

ivell 9-3 was circulated clean to a total depth of 2248 feet subsurface ( 1882 feet subsea) and was drilled 6 feet deeper to increase injectivity and ensure even injection of polymer throughout the formation. Halliburton acidized the well as follows: 500 gallons 5 percent $\mathrm{HCl}$ at no applied pressure, 1000 gallons Halliburton $M C A$ at $3 \mathrm{bbl} / \mathrm{min}$ at 300 psig, 1000 gallons 5 percent $\mathrm{HCl}$ at $2 \mathrm{bbl} / \mathrm{min}$ at $100 \mathrm{psig}$ and finally formation water at $2 \mathrm{bbl} / \mathrm{min}$ at $100 \mathrm{psig}$.

well 6-4 was circulated clean to 2487 feet subsurface and pluggea back to 2279 feet subsurface (1886 feet subsea). Halliburton acidizea the well with the sequence used on well y-3 and eventually flushed the well with formation water at $200 \mathrm{bol} / \mathrm{min}$ at $500 \mathrm{psig}$. Two-inch plastic coated tubing and a packer were run into the well and set at 2187 feet subsurface.

Well $1 \angle-4$ required several special operations. Heavy rotary mud and silt was circulated and drilled out of the well to the 7 -inch casing shoe at 2261 feet subsurface 


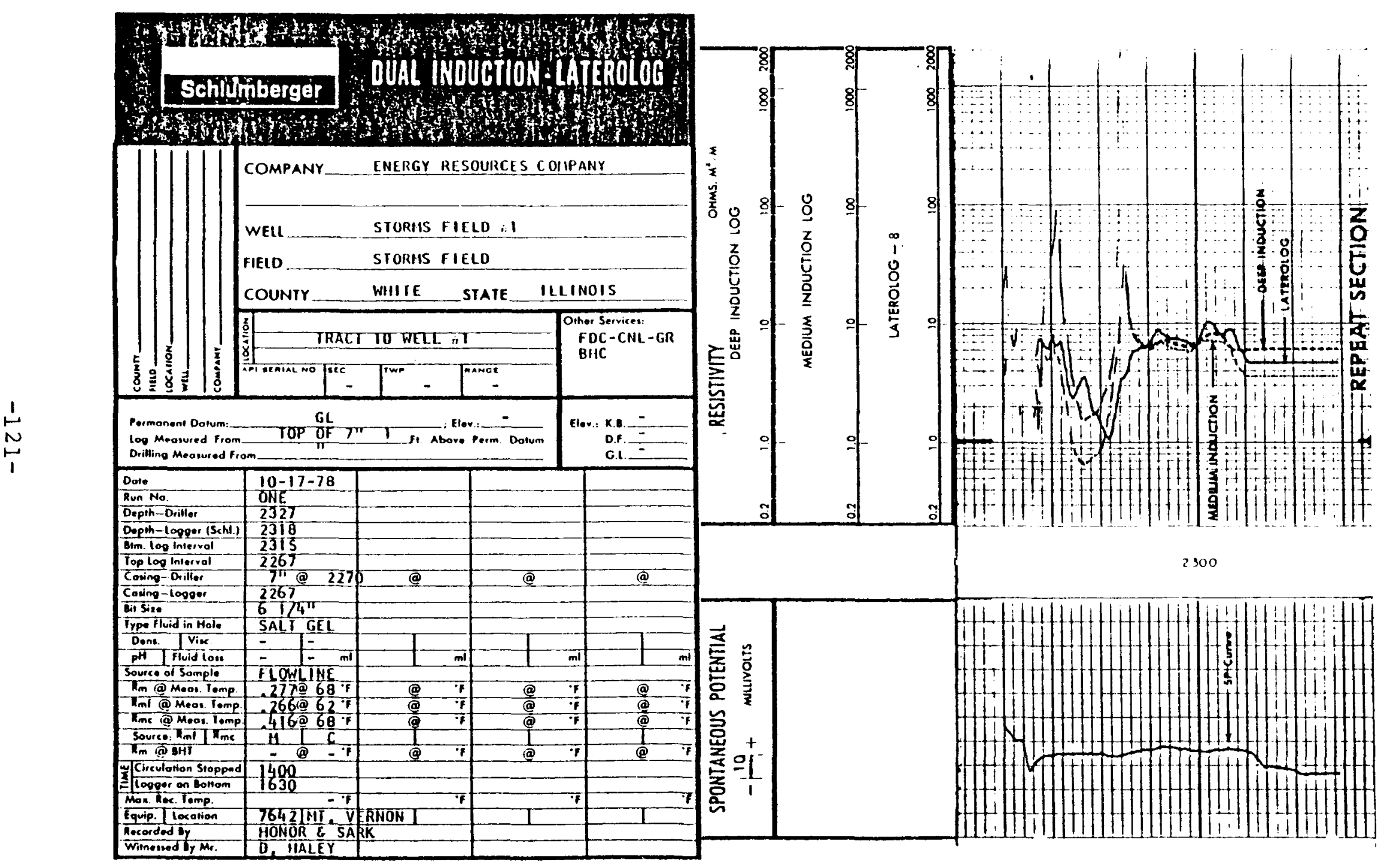

Figure 63. Dual Induction Laterolog, Well 10-1. 
(1864 feet subsea). The casing, which was perforated into the gas cap during primary production, was squeezed with cement and left to set. The cement was then drilled to the top of an old string of tubing which was left in the hole. This tubing was cut off about 100 feet below the target interval, and the well was cemented back to 2281 feet subsurface. After circulating clean, the well was acidized according to the program described above and was flushed with $0.5 \mathrm{bbl} / \mathrm{min}$ of formation water at $1000 \mathrm{psig}$. This was judged unsatisfactory, and when the well was entered for pressure testing the completion interval appeared to be completely blocked with heavy mud and cement debris.

The well was recleaned and acidized with only marginal improvements in injection rates, eventually taking $12 \mathrm{bbl} / \mathrm{hr}$ at 300 psig. A light 10,000-gallon hydraulic fracturing of the interval with 20-40 sand at 1800 psig increased injection rates to $6 \mathrm{bbl} / \mathrm{min}$ at $225 \mathrm{psig}$.

Two-inch plastic-coated injection lines were installed and connected with each injection well. Figure 64 summarizes the current status of the six injectors.

\subsection{Production wells}

of the four original producing wells in the project, two were cleaned and fitted with rods and tubing in 1978 . In 1979 the rods and downhole pumps in Wells 10-2 and 10-4 were replaced. These wells are both currently producing a total of $10 \mathrm{bbl} / \mathrm{day}$. Pumping units for the three remaining wells are being installed. Well 9-4 required an 8-foot substructure. Three-inch PVC flowlines connect each producer to a tank battery on Tract 10 . 


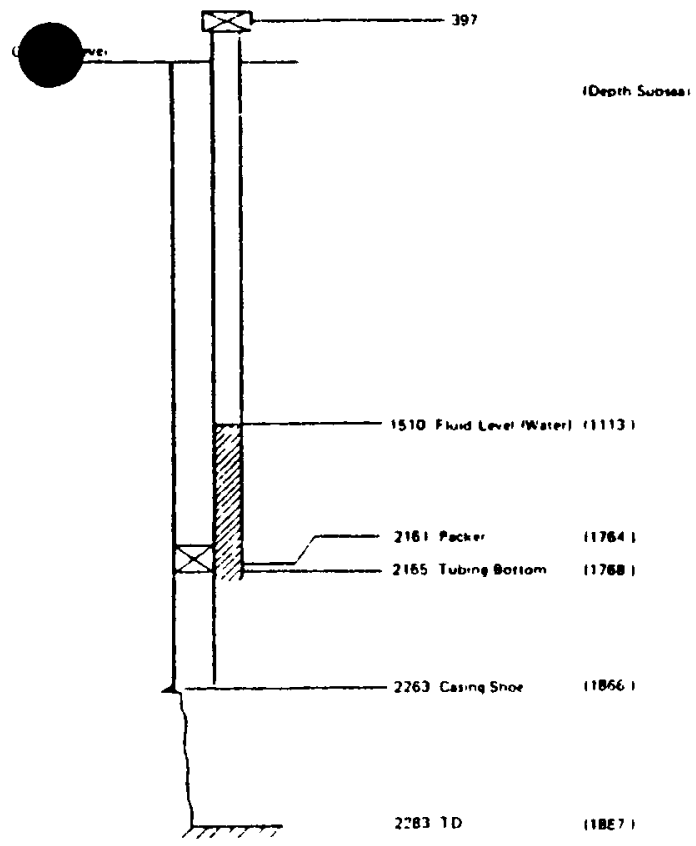

$\stackrel{1}{N}$
Profile of Well 9-2, October 18, 1979

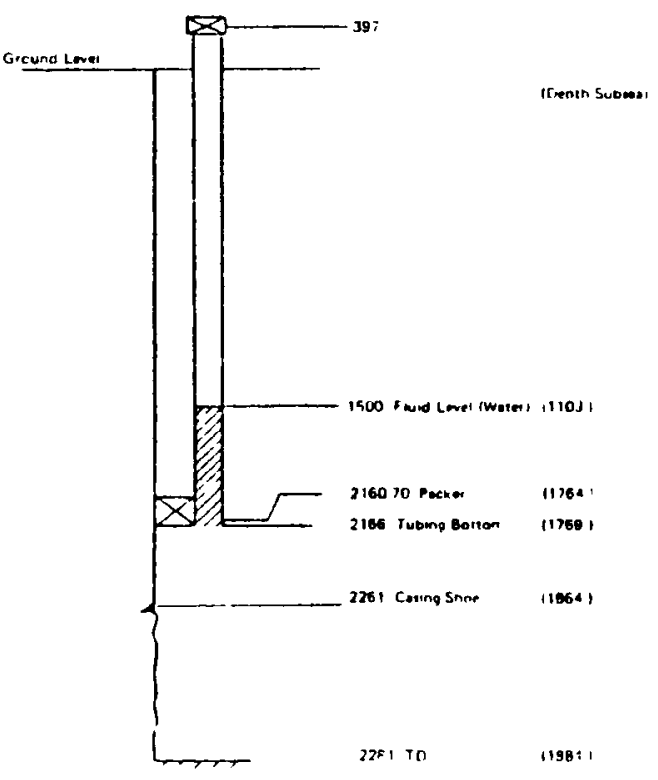

Profile of Well 12-4, October 17, 1979

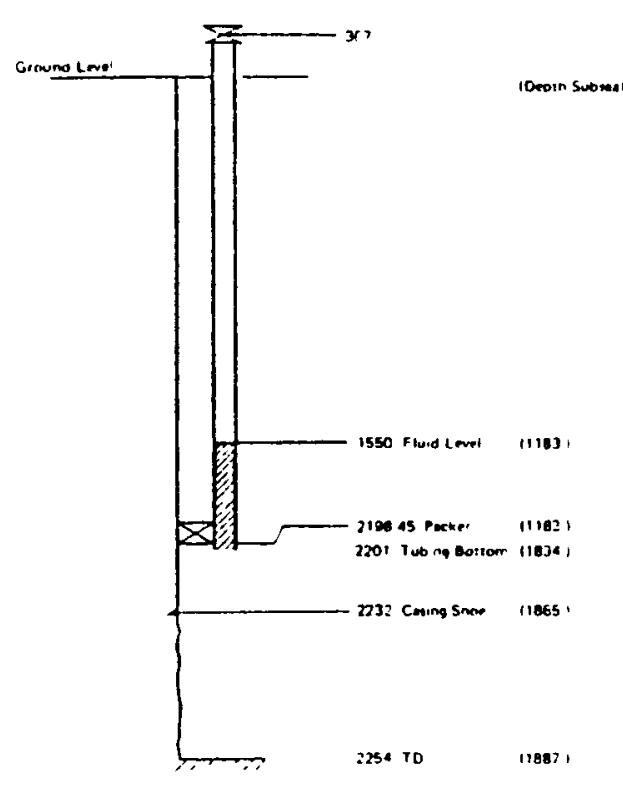

Profile of Well 9-3, October 17, 1979.

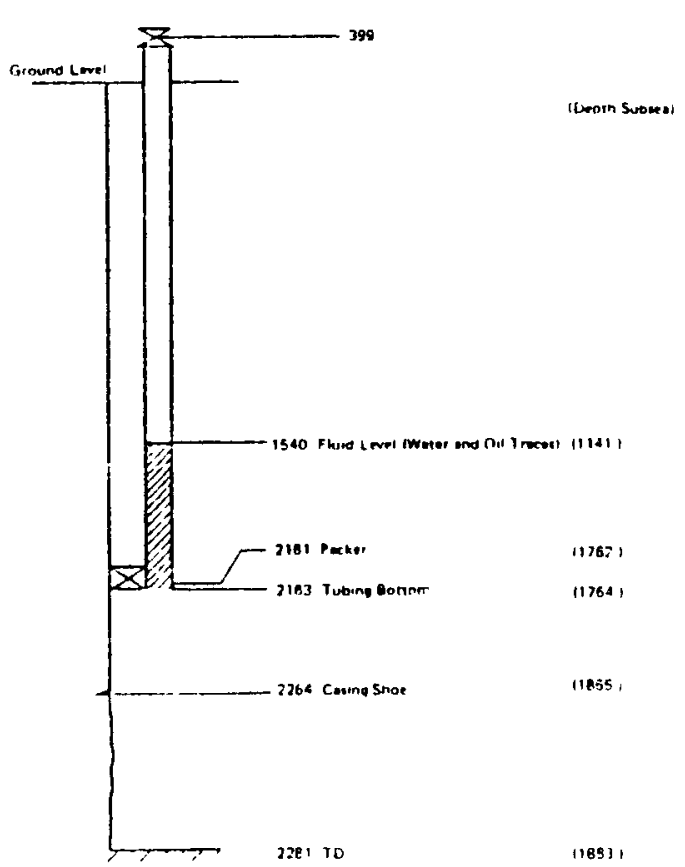

Profile of Well 10-1, October 18, 1979.

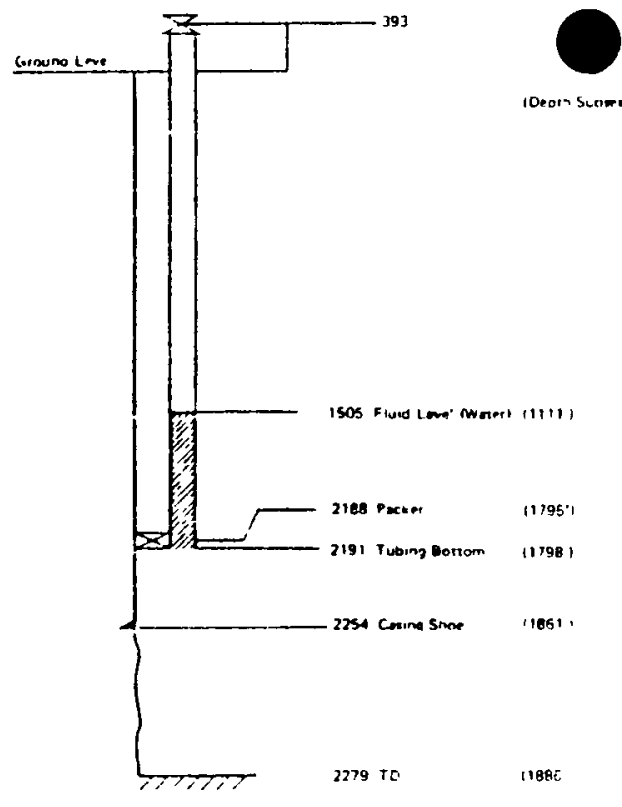

Profile of Well 6.4, October 19, 1979

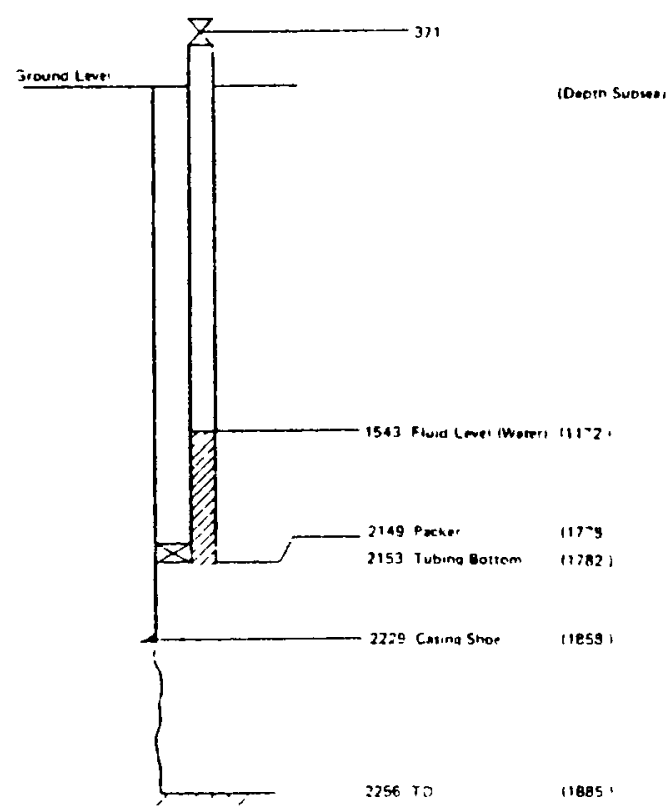

Profile of Well 10-3, Octobel 19, 1979

Finure 64. Profiles of Storms Pool pilot injection wells. 
-

$-124-$ 


\section{CONSTRUCTION OF FACILITIES}

Essentially all the construction and fabrication of the polymer injection facility and connecting pipeline and electrical network completed to date was performed during the period covered by this report. In 1978 only some preliminary design and preparation was completed in conjunction with the geologic and engineering analysis of the reservoir. During 1979 detailed design of the injection facility, purchasing of required equipment items and preparation of the field progressed simultaneously throughout the first half of the year. The final design and shipment of equipment to Carmi was completed during the third quarter of 1979 , and fabrication of the facility and connecting fluid network occupied the last months of 1979 in preparation for water injection.

\subsection{Preparation of the Pilot Site}

Construction of the injection plant required extensive preparation of the site, field access roads, and existing equipment. The injection plant site was graded and cleared of debris and 60 tons of 3/4-inch gravel was spread as a base for the polymer storage and mixing tank battery. In addition the grader distributed 30 tons of 1 -inch gravel along the field roads to improve access. A trailer bed hull serving as a bridge was set over a creek that runs between the plant site and Tract 9. Figure 65 shows the field road network.

In conjunction with the preparation of the field site, much of the existing equipment in the field was upgraded. New sucker rods were purchased for each production well and existing pumps were inspected. In all, 9,200 feet of 2-inch I.D. steel pipe, tested to 10,000 psig, were bought, sandblasted and epoxy coated for use as injection line.

This phase of construction was frequently interrupted and postponed by snow and freezing weather. However, most of the essential preparation was accomplished in the scattered periods of fair weather early in the year, and the field was ready for active construction during the summer.

\subsection{Plant Design and Purchasing of Equipment}

The design of the injection facility evolved through several stages of complexity. During this design phase 


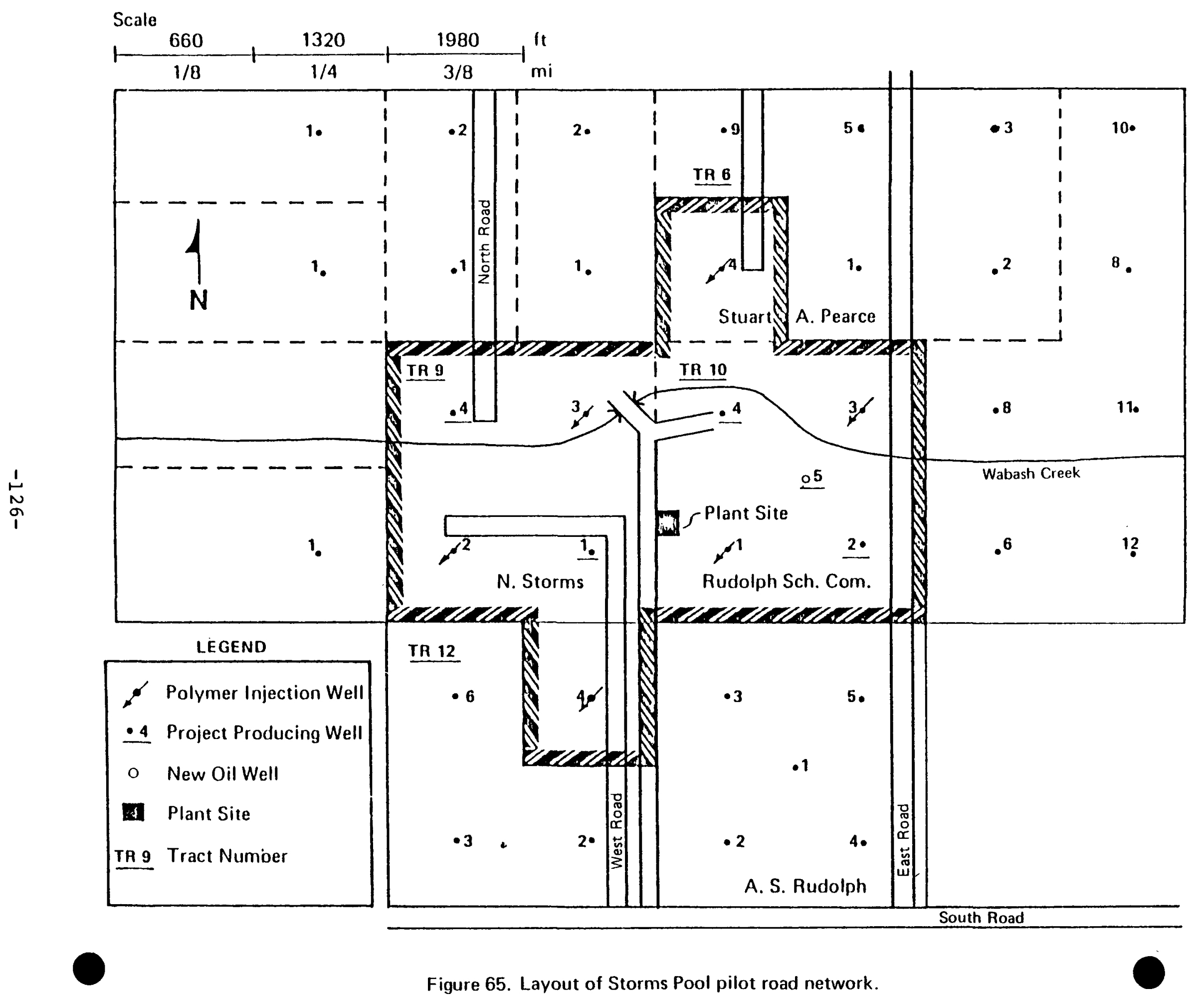


large equipment items with long lead times were ordered wherever possible. A tri-filtering system, manufactured by Culligan International Corporation, was ordered in December 1978 to filter the injection water from the Little Wabash River. Each of the three units is capable of filtering 75 $\mathrm{gal} / \mathrm{min}$ of water. Our design flow rate calls for a maximum of $110 \mathrm{gal} / \mathrm{min}$; therefore two units will easily handle the required flow while the third is cleaned by backwashing. In addition a Gardiner Denver PT4L triplex plunger pump was purchased for use as the main injection pump. The pump was previously used at a car wash for approximately 6 months. Al1 parts of the pump, including valves, seats, plungers, and belt drive, were inspected and showed very little wear. The pump was guaranteed to operate properly by the vendor, Simpson Brothers in Fairfield, Illinois.

During this period we chose a building contractor after receiving quotes from several contractors in the area. Plans for the injection building were finalized in January, 1979 and the metal building shell was assembled on site in February. The concrete foundation was not poured until April due to bad weather. The final structure is 30 feet wide and 36 feet long with 12-feet-high walls. The floor is 4-inch-thick concrete, with the exception of the area under the triplex pump which is 6 inches thick. A 12-foot $x$ 15-foot office has been partitioned off. A 3-foot-wide and 3-foot-deep drainage trench runs lengthwise through the building. The layout of the building is depicted in Figure 66 .

Anderson \& Son Electric began work on electrification of the plant and pumping wells in January. By April three transformers were installed adjacent to the injection facility. These transformers step the primary voltage of 12,500 volts down to 400 volts.

A preliminary version of the piping and instrumentation diagram (P\&ID) was produced in January and revised several times through July based on input from DOE, polymer suppliers, and other oilfield operators. The preliminary version is shown in Figure 67. By the end of July all equipment had been ordered with the exception of instrumentation. The Appendix is a list of the equipment and the vendors which supplied them.

During July and August injection and flow lines were laid in the field and connected to each well. Injection lines were brought to the east end of the injection plant for connection to the pump upon completion of the plant. PVC flow lines were linked to each production well and to 


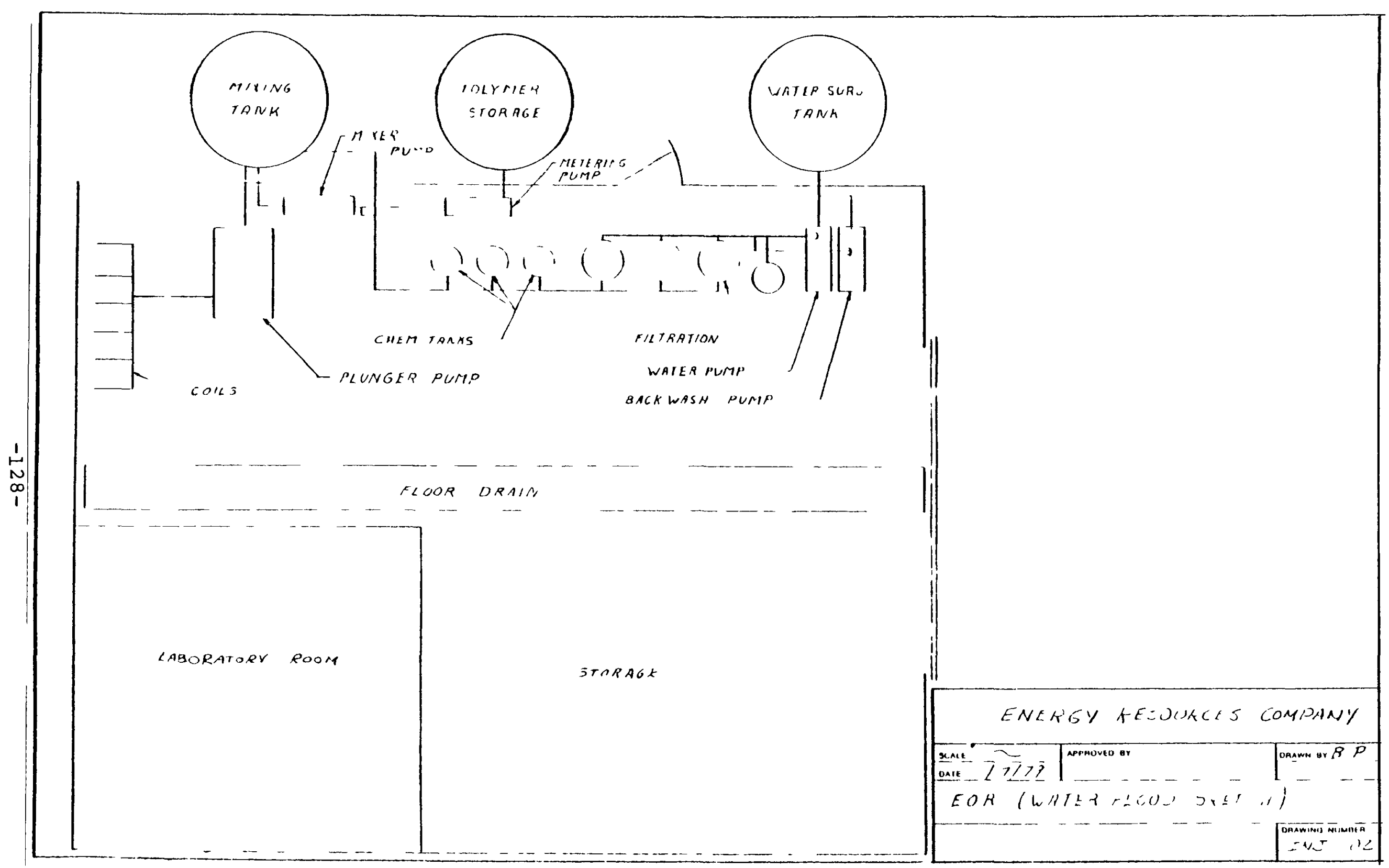

Figure 66. Injection plant layout. 


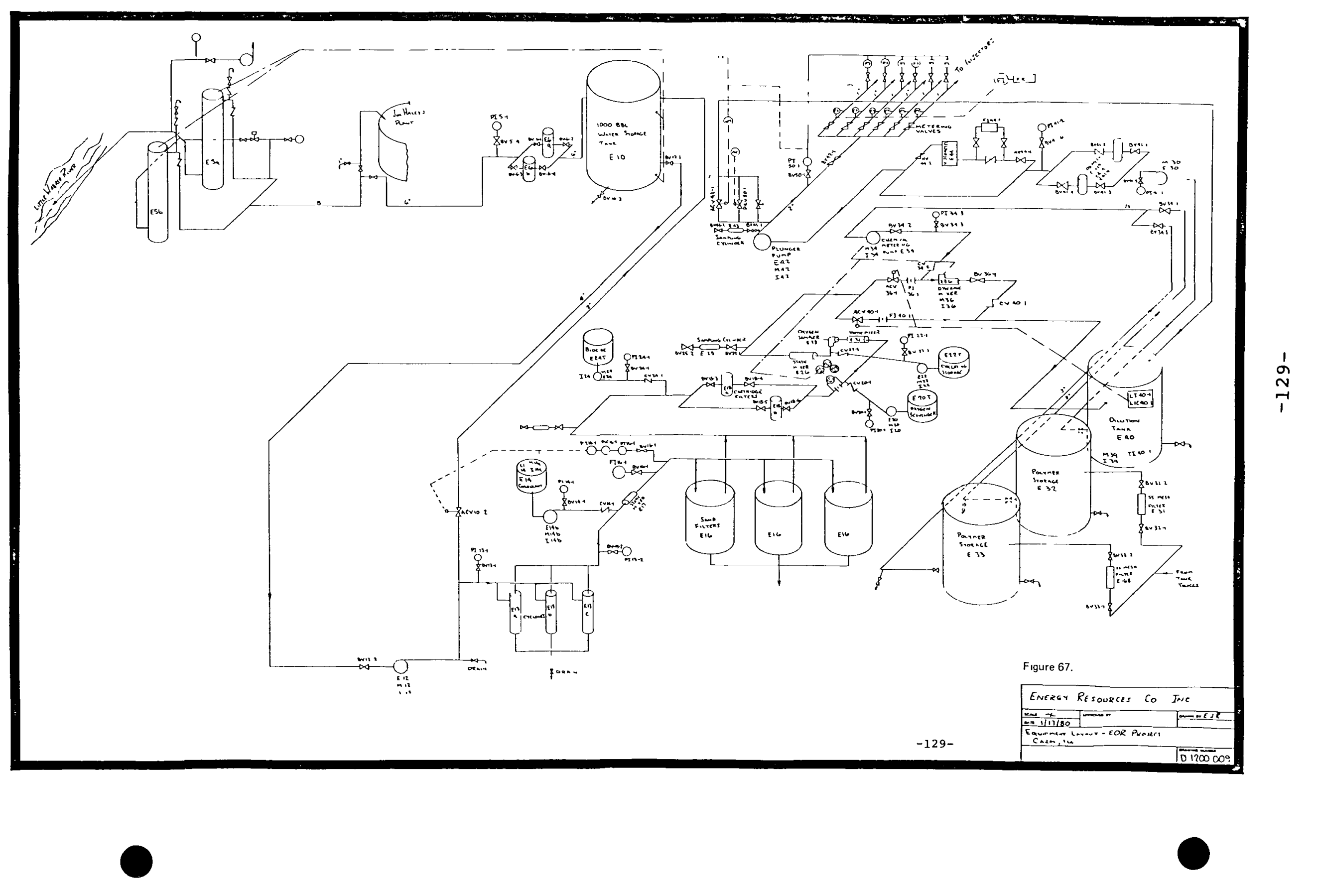


the existing tank battery on Tract 10. Existing flow lines were replaced with 3 -inch PVC pipe, and an additional

freewater knockout will enable us to monitor production from a single well by keeping it separate from the rest of the production. Each well will be periodically monitored in this way.

The method of fresh water supply was finalized during this period and the existing pumps at the river station were examined. A 1000-barrel tank was ordered from a local fabricator and placed at the injection plant. The fresh water supply method hinged on the ability of the river pumps to supply water the extra 3000 feet from the original waterflood plant to our facility. The manufacturer, Layne Western, indicated that the pumps could supply water against the calculated head but also discovered that one of two river station pumps was inoperable. This pump was sent to st. Louis and rebuilt.

Some revisions in this P\&ID were made in september at the suggestion of our subcontractor, Elf-Aquitaine. By October 1 all equipment and instrumentation was ordered and much of it had been delivered to the site. The absence of several items, significantly the cartridge filters and PVC valves, forced us to postpone fabrication until November 1979. However, during the preceding months steady progress in construction had resulted in detailed plans of a welldesigned system, enabling us to complete 90 percent of the fabrication of the injection facility in the final months of 1979 .

\subsection{Fabrication of the Injection Plant}

The internal piping, wiring and installion of equipment in the injection facility began in November, 1979. The arrival of several key pieces of equipment in October allowed two-thirds of the internal piping to be completed in 2 weeks. In additon, the 1000-barrel water tank was completed and light and heat installed in the facility. By the end of November, all piping within the plant, with the exception of the stainless steel manifold downstream of the triplex pump, had been assembled. In December the 6-inch line linking the original waterflood plant to our facility was completed, and the river pumps were reinstalled and readied for service. The 75-horsepower motor for the triplex pump was delivered and set up on skids. An 8-foot framework base for the pumping unit at Well 9-4 was constructed to compensate for its position low in the creek bed. 


\subsection{Current Status}

All equipment essential to the injection of water is on site and assembled awaiting the installation of some basic instrumentation and wiring. The final assembly of the stainless steel connections to the injection lines is in progress, as is the wiring of the motors in the plant. Production must begin, and insulation of all tanks and exposed lines must be checked closely before injection can be started. 
○

$-132-$ 
SECTION SEVEN

\section{RESERVOIR SIMULATION}

During 1979 Energy Resources and Elf-Aquitaine agreed on a plan for simulating the storms pool pilot project and conducted simulations supporting the preliminary design of a polysaccharide slug to be injected. This section summarizes these activities.

\subsection{Simulation strategy}

In February, 1979, Energy Resources' project team met with Elf-Aquitaine to plan the project's simulation work. For contractual reasons they decided not to use Energy Resources' polymer flood simulator but instead to rely on Elf-Aquitaine's two-dimensional stream-tube simulator. This model has been used with good results in the Chateaurenard field in France's Paris Basin. The overall plan for using this simulator is as follows:

$$
\begin{aligned}
& \text { Stage I - Run the simulator with preliminary data } \\
& \text { to define stream-tubes, investigate the } \\
& \text { effects of a possible field-wide drift on } \\
& \text { fluid flow, and estimate the size of the } \\
& \text { polymer slug needed to flood the pilot } \\
& \text { area. }
\end{aligned}
$$

Stage 2 - Run the simulator using more detailed and better confirmed data to determine injection strategy.

Stage 3 - Monitor field performance quarterly.

Stage 1 was completed during 1979.

\subsection{Preliminary simulator Runs}

The preliminary simulator runs (Stage 1) modeled two cases, drawn in Figure 68. Case I includes six injectors and five producers, approximating the influence of the rest of the field by the choice of boundary. No field-wide drift is assumed. Case I includes a subcase $I^{\prime}$ in which a higher value of polymer retention is assumed. Case II includes the 11 wells of the pilot area plus four artificial injectors and four artificial producers to simulate a hypothetical fluid drift possibly resulting from uneven field-wide 


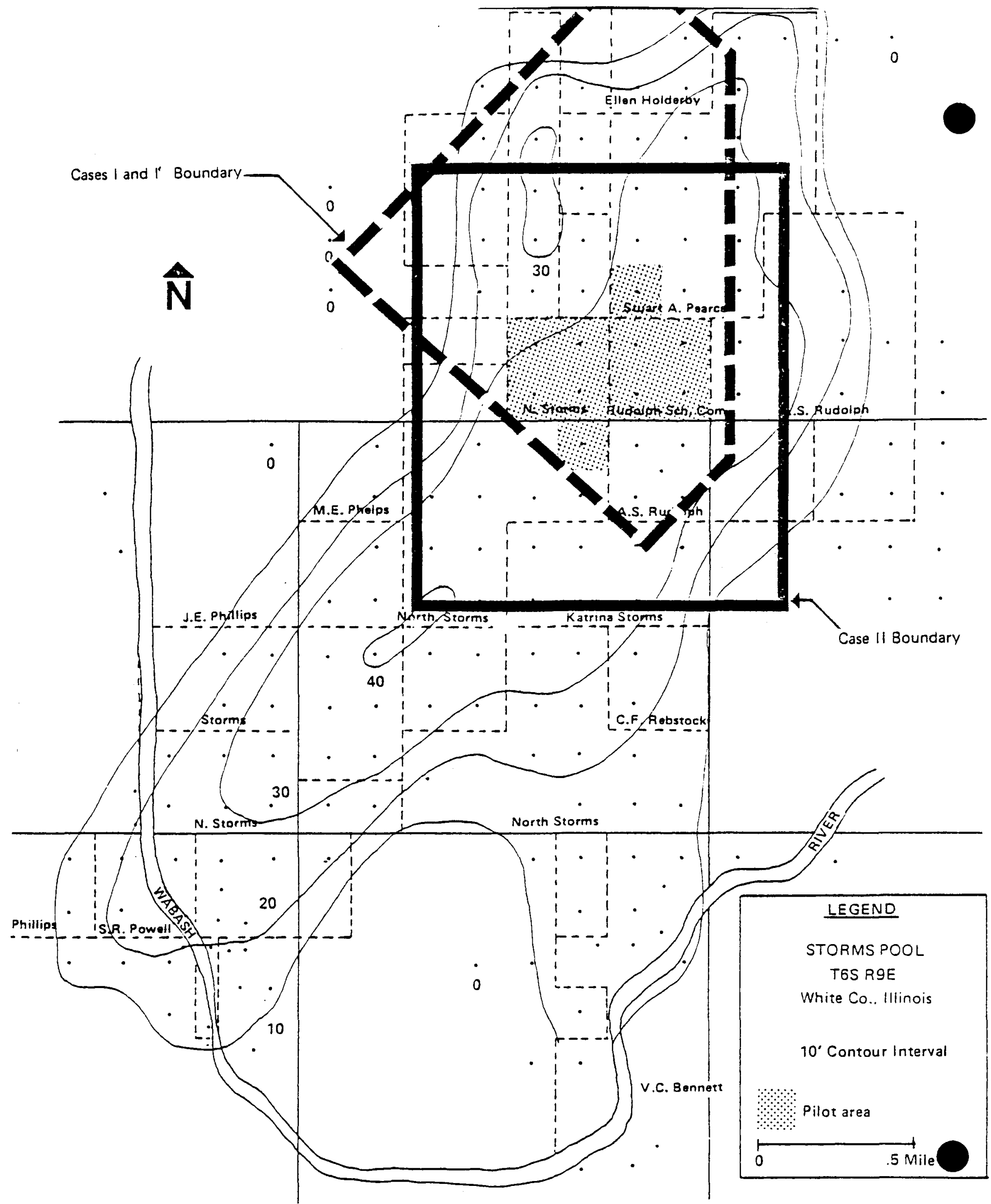

Figure 68. Boundaries assumed in three preliminary simulation cases. 
distribution of injectors and producers. Tables 29 and 30 list the reservoir properties assumed in the runs.

In generating the stream-tubes for both cases, boundaries were chosen to approximate the no-flux boundary conditions assumed in the model. Figure 69 shows the stream-tubes generated for cases I and $I^{\prime}$. Notice that streamlines leaving project injectors terminate at project producers, so that the pilot pattern is well confined. Figure 70 shows the stream-tubes generated for case II using the injection and production rates listed in Table 30. Here the flow from project injectors is not confined to the pilot pattern; in particular a large portion of the fluid injected at Wells 6-4, 9-3, and $10-3$ is lost along with mobilized reservoir fluids to the north and east. We judged that this potential loss of fluids from the pilot area could have important implications for the polymer injection strategy and that the influence of the rest of the field should be measured. Section 2.2 reports the results of these measurements.

Each case was simulated assuming 1500 days of operation and a 189,000-barrel slug of 500 ppm polymer followed by water at each pilot injector. Figures 71,72 , and 73 show the performance predictions for cases $I, I^{\prime}$, and II, respectively. The initial oil cut is approximately 2.8 percent, compared with the present observed value of about 2.0 percent. Figure 74 compares the cases side by side. After injection of 1.25 pore volumes the gains in oil production over waterflood predictions are as follows:

Case

I (no drift, $20 \mu \mathrm{g} / \mathrm{g}$ retention)

$I^{\prime}$ (no drift, $30 \mu \mathrm{g} / \mathrm{g}$ retention)

II (drift, $20 \mu \mathrm{g} / \mathrm{g}$ retention)
Oil recovered in excess of waterflood

$111,000 \mathrm{bbl}$

$80,000 \mathrm{bbl}$

$80,000 \mathrm{bbl}$

These results indicate that field-wide drift and high polymer retention can each lower the additional oil recovery by about 30 percent. As reported in previous sections of this report, pressure tests revealed no strong field-wide fluid drift, and core floods using filtered polysaccharide solution gave a value of $16.34 \mathrm{\mu g} / \mathrm{g}$ rock for polymer retention. 
TABLE 29

RESERVOIR PROPERTIES ASSUMED IN PRELIMINARY SIMULATOR RUNS

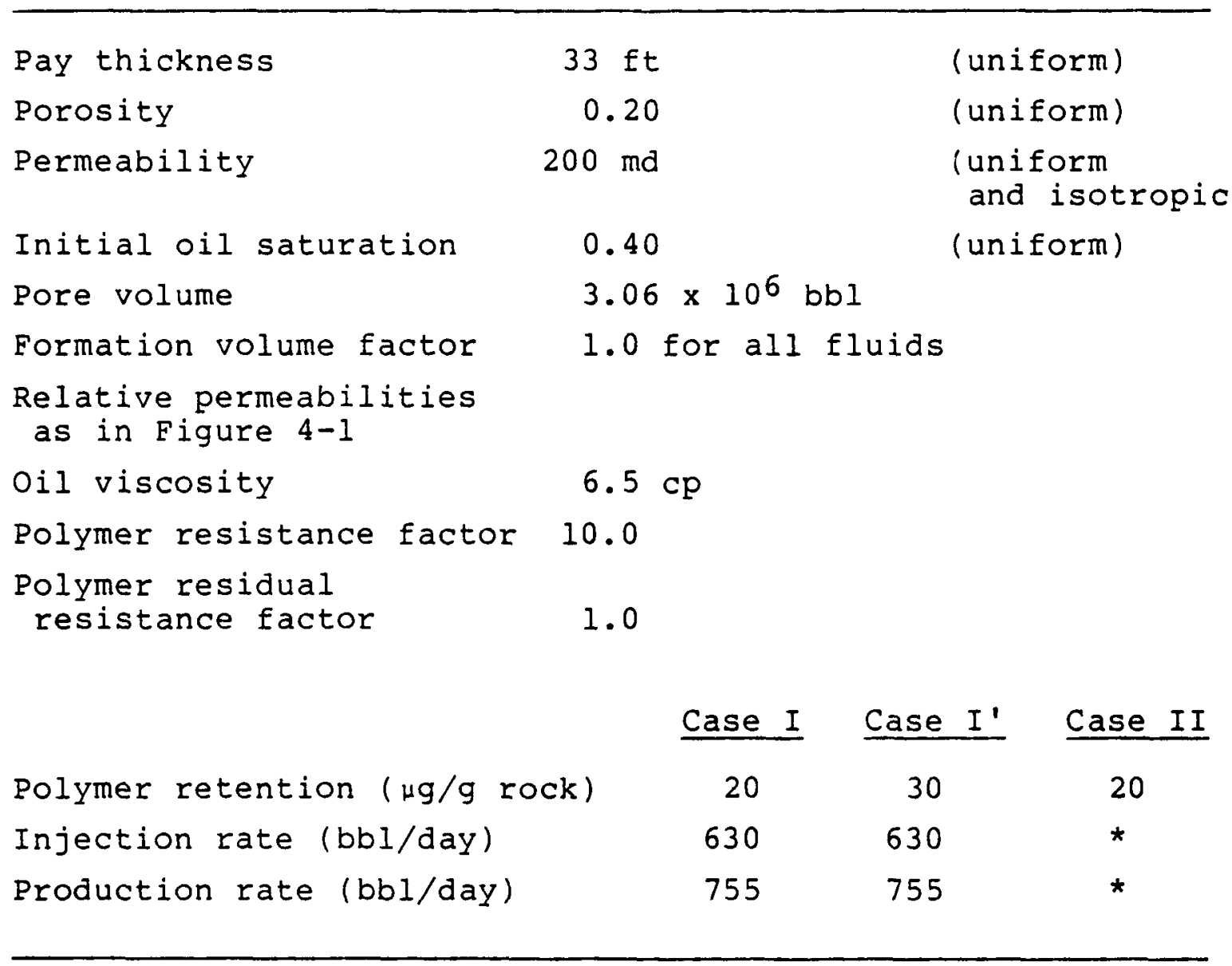

* See Table 30. 
TABLE 30

INJECTION AND PRODUCTION RATES ASSUMED, MODEL CASE II

WELL

All pilot injectors

(polymer followed by water)

Pilot producers

$$
\begin{array}{r}
9-4 \\
10-4 \\
10-5 \\
9-1 \\
10-2
\end{array}
$$

Artifical injectors (water only)

II

I 2

I3

I 4
RATE (bbl/day)

$$
630
$$

855

905

630

630

630

Artificial producers

PI

P2

P3

P4
380

630

315

380 
= injector

$=$ producer

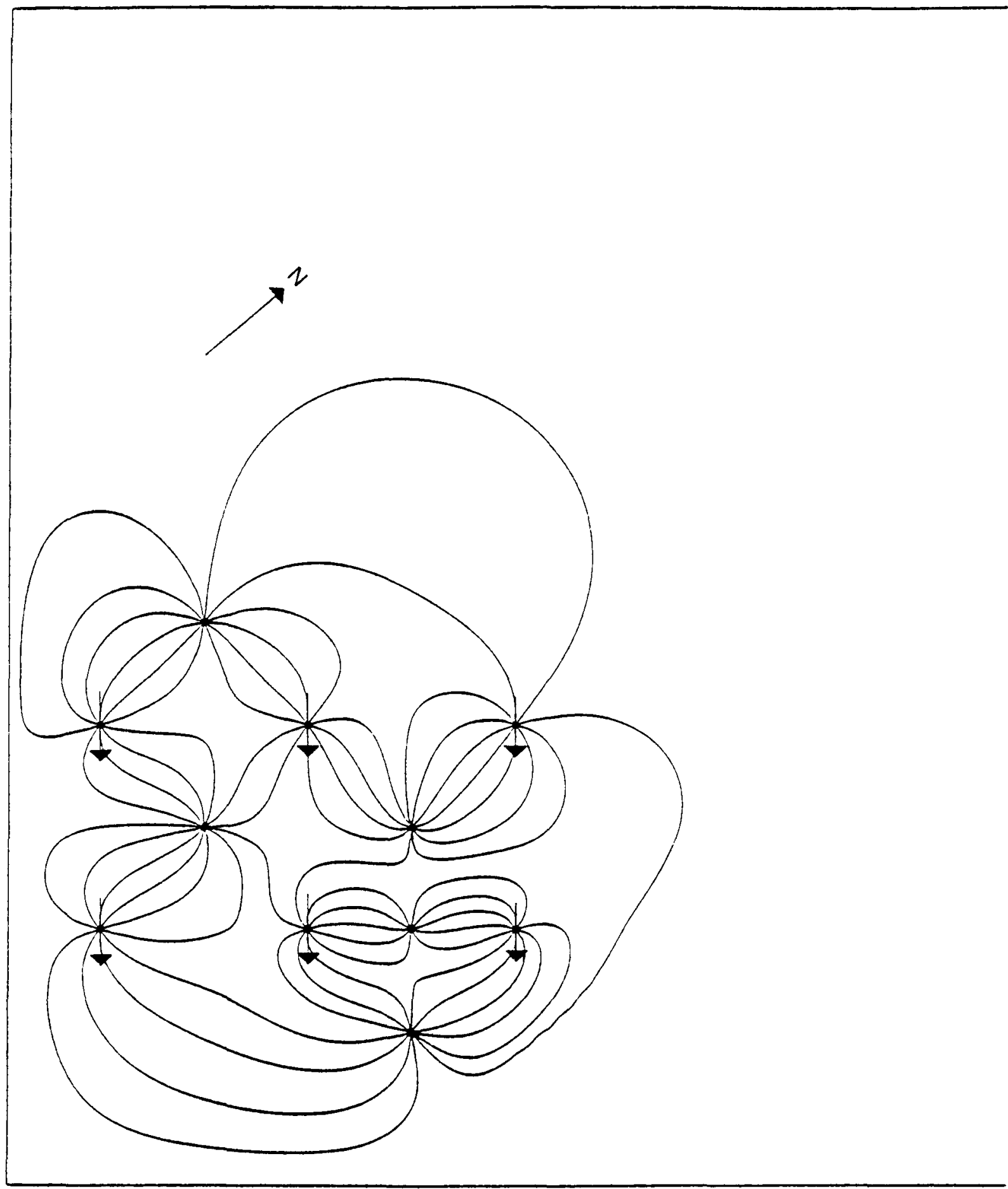

Figure 69. Streamtubes generated by polymer flood simulator for Cases ! and I' (no drift). 
$=$ injector

= producer

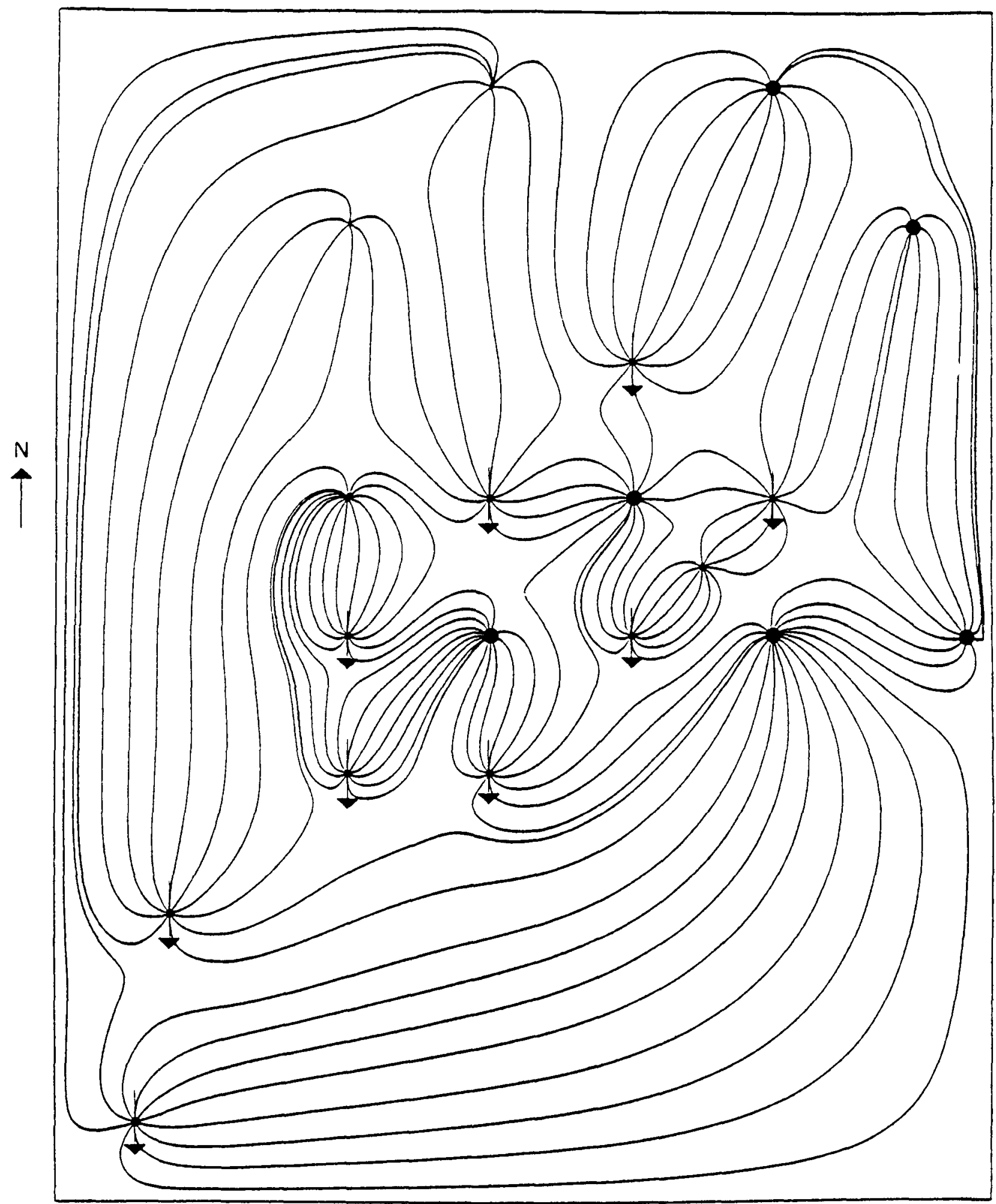

Figure 70. Streamtubes generated by polymer flood simulator for Case 11 (drift from southwest to northeast). 


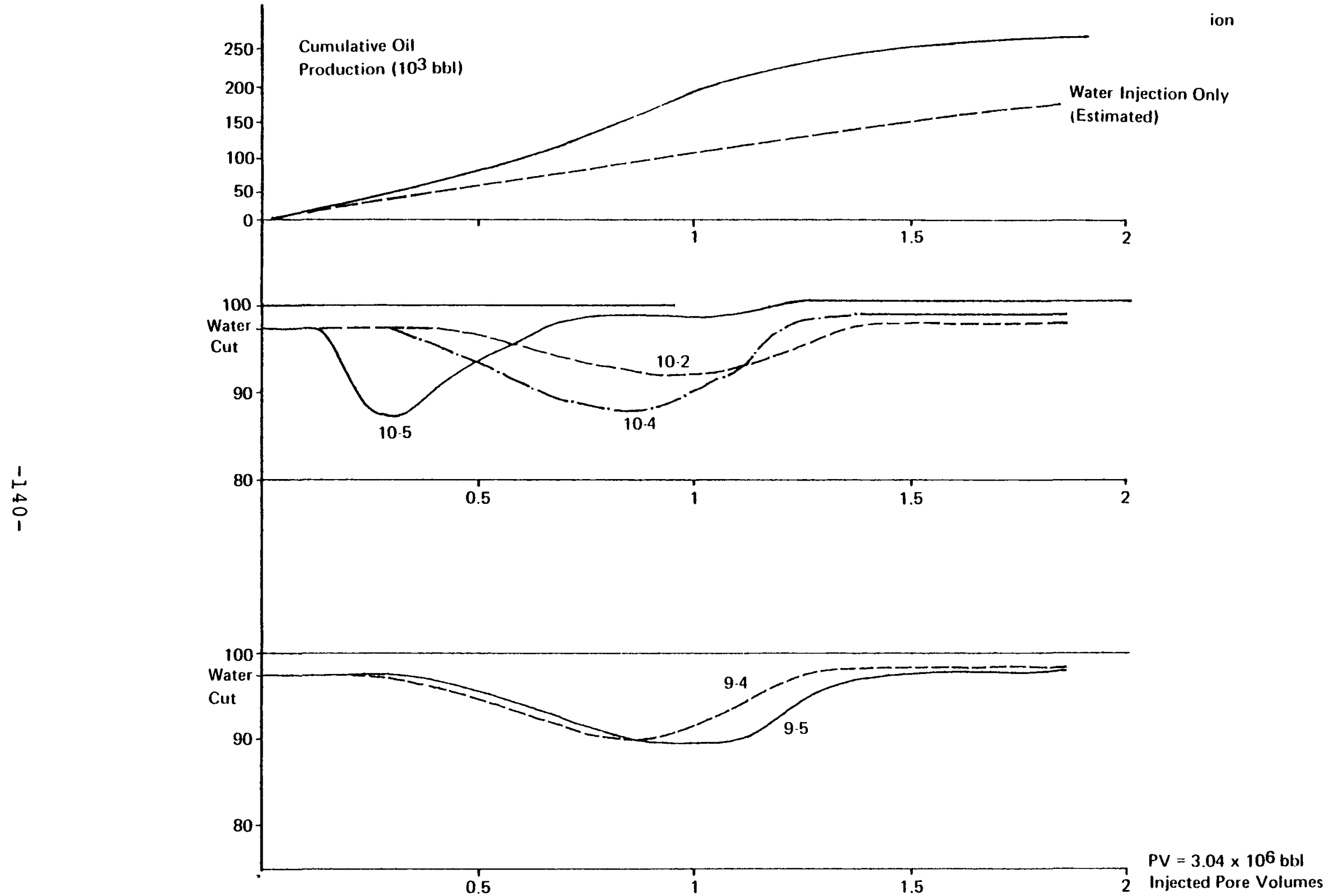

Figure 71. Simulator performance predictions for Case I (no drift, retention $=20 \mu \mathrm{g} / \mathrm{g}$ rock). 


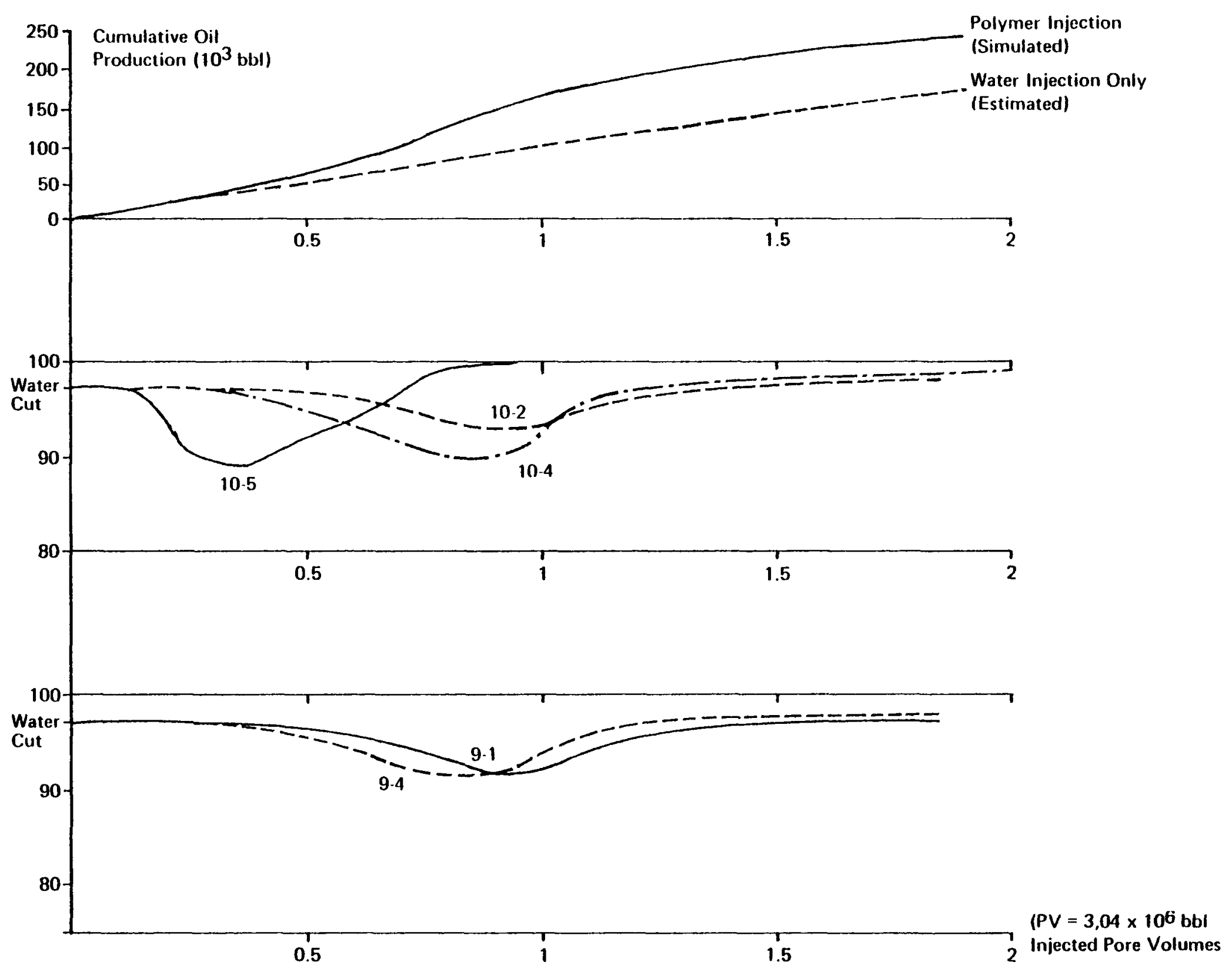

Figure 72. Simulator performance predictions for Case I' (no drift, retention $=30 \mu \mathrm{g} / \mathrm{g}$ rock). 


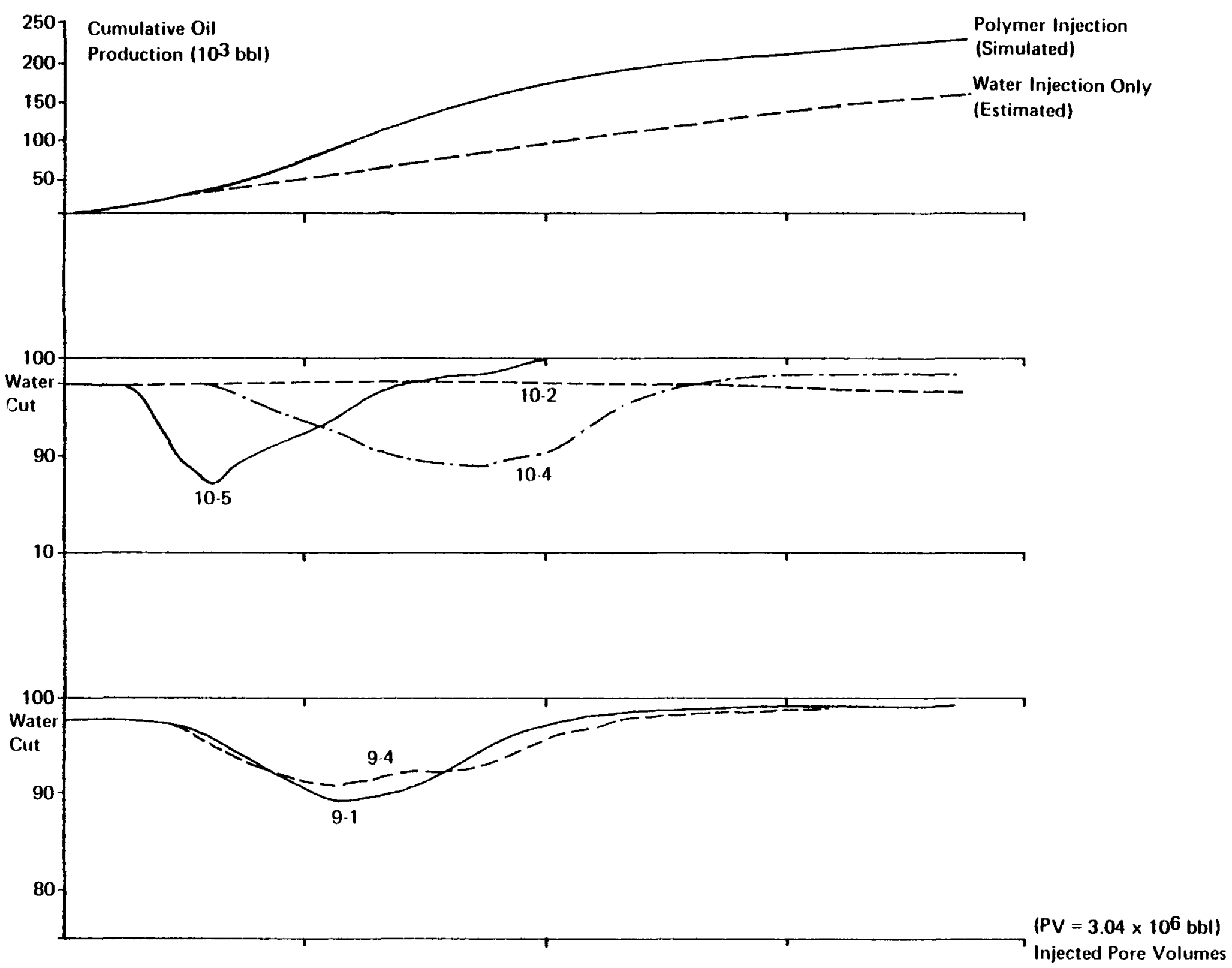

Figure 73. Simulator performance predictions for Case $\|$ (drift, retention $=20 \mu \mathrm{g} / \mathrm{g} \mathrm{rock}$ ). 


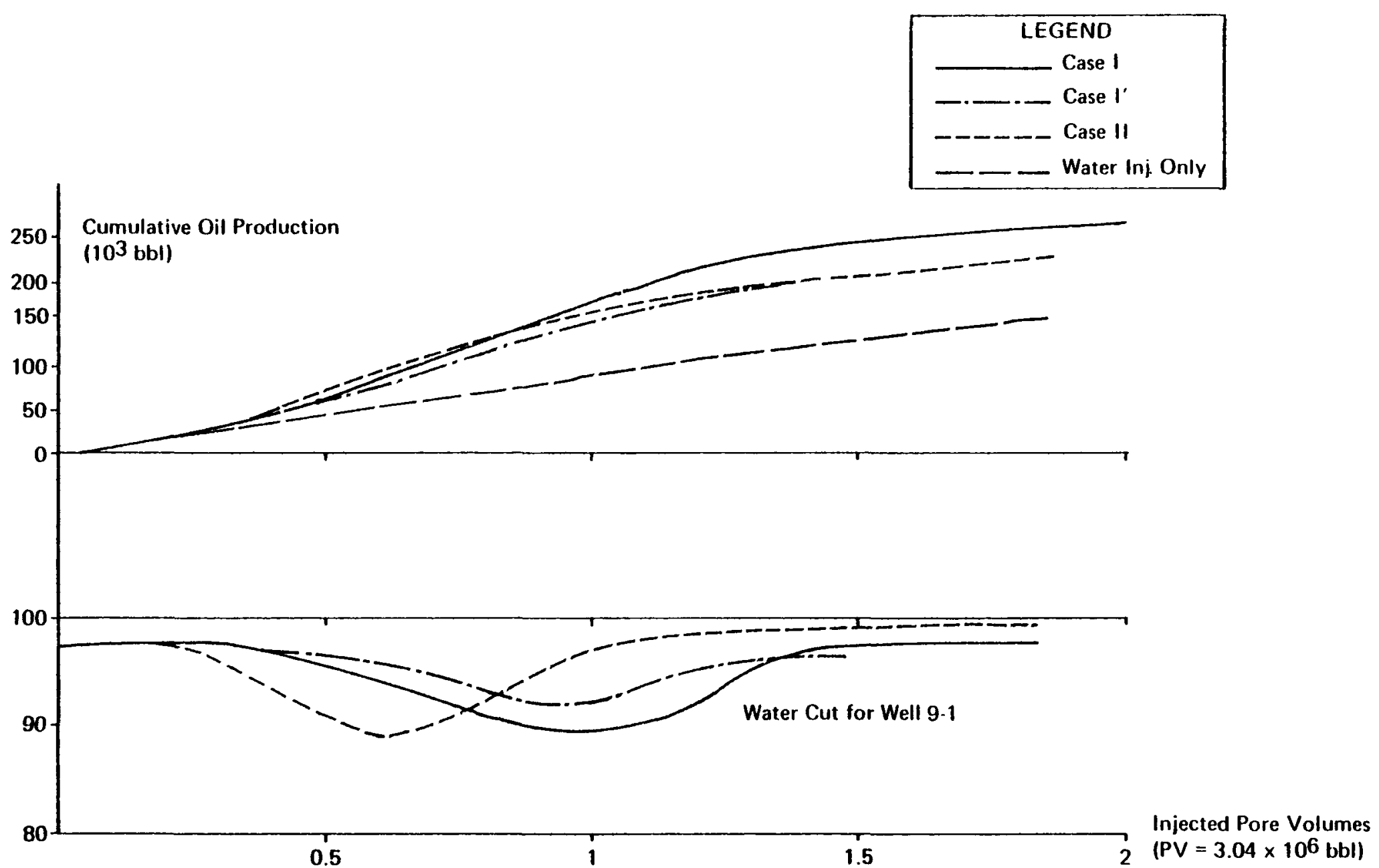

Figure 74. Comparison of simulator performance predictions for CasesI, I', and II. 
-

$-1440$ 


\subsection{Purchase of Polymer}

After deciding to use a polysaccharide, Energy Resources began negotiations with polymer manufacturers to find the best combination of product quality and price. Laboratory data (see Section Three) indicated that Pfizer's product had the best performance characteristics, and this company was willing to supply polymer from their Groton, Connecticut plant.

Pfizer's price per active pound was competitive with other manufacturers, but the shipping expenses from Groton to Carmi nearly doubled this cost. Pfizer suggested several ways of reducing this transportation cost. First, they suggested that they might move production to Terre Haute, Indiana if some fermentation capacity opened up there in time. Second, the possibility of producing a higher concentration broth (up to 9 percent) seemed likely at that stage. Finally, failing the first two, Pfizer agreed to consider paying a portion of the freight costs.

At this point Energy Resources requested price proposals from both Abbott Chemicals and Kelco. Abbott replied that no excess production capacity was available in 1979 or early 1980. Kelco on the other hand offered to supply biopolymer broth out of their Okmulgee, Oklahoma plant. Although this offer represented considerable savings in Ereight, Kelco was unable to match Pfizer's price for broth since the okmulgee plant normally produces powder. In addition, the kelco broth performed less acceptably in the laboratory tests.

Pfizer's offer to pay 25 percent of freight costs virtually eliminated Kelco's slight price advantage, but Kelco was willing to lower their price further if necessary. Still, close examination of Kelco product indicated that it might require diatomaceous earth filtration prior to injection. This would cause an unacceptable increase in our cost; therefore when Pfizer lowered their price $\$ 0.10 / 1 b$ to remain competitive with Kelco, Energy Resources sent Pfizer a letter of intent to buy up to 250,000 pounds of Flocon 1035 biopolymer.

Precise terms and agreements are being drawn up based on a meeting held in Cambridge on December 4, 1979. General 
specifications of polymer quality were also drawn up in that meeting and are outlined in section 4.3. The final agreement will be signed in January, 1980 and will include provisions for discontinuance of polymer purchases and escalation of price with raw material costs. First polymer delivery is expected in March, 1980.

\subsection{Environmental Assessment and Environmental Protection Plans}

In November, 1979, a draft environmental assessment ${ }^{1}$ of the Storms Pool pilot polymer: flood was completed by Energy and Environmental Analysis, Inc. of Arlington, Virginia and submitted to the DOE's Office of Fossil Energy. This assessment was prepared in accordance with the DOE's proposed guidelines for compliance with the National Environmental Policy Act (FR44, No. 139, p. 42136); the report evaluates environmental impacts of the project on the site, the existing air and water quality, the surrounding community, and the health and safety of project workers. Included is a description of proposed alternative actions to the existing project; both the "No action" and "Alternative site" options are explored.

The assessment concludes that there are no major potential long-term environment impacts associated with the construction and operation of the polymer flood in its present location. Short-term effects are expected to last only for the duration of the project. The project wi l probably have no appreciable impacts on surface and groundwater quality, socioeconomics, or historical and archaeological resources. The report also states that the alternative options "No action" ar "Alternative site" would not necessarily be better on environmental grounds than the planned project.

The existing air quality near the project site is good, and at the nearest air quality monitoring station pollutant levels are below short-term and annual air quality standards. Air quality impacts from the project have been and will be negligible. Fugitive dust emissions during facility construction were minor, and the only significant sources of air emissions during operation will be low-level vehicle exhaust. Roads have been or will be resurfaced to reduce fugitive dust emissions.

\footnotetext{
${ }^{1}$ Environmental Assessment of the Department of Energy/ Energy Resources Company Polymer Improved Waterflood (Draft) Energy and Environmental Analysis, Inc. for U.S. DOE Contract No. EF-77-C-01-2624, November 1979 .
} 
Water samples have been taken from the Little Wabash River and the turbity level is extremely high. No degradation of surface water from the pilot project operations is anticipated. No process wastewater from the project will be discharged intentionally into any surface waters in the area; all wastewater will be disposed of underground via the brine reinjection well into oil-bearing formations. The EEA study concludes that there is virtually no possibility of significant groundwater contamination in the project area.

Socioeconomic impacts of the Storms Pool project will be insignificant due to its small manpower requirements. The project is not expected to cause any significant noise impact. The maximum noise level probably occurred during construction or drilling and apparently had no significant impact on humans or wildlife. Most of the noise henceforth will be contained in the injection facility. Production well operations are powered electrically, and noise is not a problem there.

No significant impacts on land use are expected. Oil production has been a major land use at the project site since 1939. The oil field is in an agricultural area, and soybeans and corn have been grown on the surface concurrently with oil production. The pilot project permits continuation of these previous land uses.

At time of the assessment the project site and surrounding area had received unusually heavy rains, and some surface areas on the site were in poor condition. Most areas were expected to dry out in the later, dryer parts of the summer. Project funds were used to resurface the injection plant access road with gravel to prevent run-off problems. Cleanup efforts have been planned for the oil storage tank and production well areas, where previous activities of another operator had left debris and oil standing on the surface.

\section{Environmental Protection Plan}

Three types of potential pollutants will be of concern at the project facility:

1. Filtration wastes from filtering of river water for injection.

2. Polymer storage tank residues and filtration wastes from pre-injection polymer solution filters.

3. Above-surface hydrocarbon leaks or spilis at the project site, as addressed in federal regulation 40 CFR 112 and amendments. 
The methods used to dispose of these wastes are regulated by various state and federal regulations. The following waste disposal practices have been outined in ERCO's Environmental Protection Plan.

The filtered wastes from the river water cleanup system will be composed of sediment and debris and are not considered hazardous wastes. Any liquid wastes from the system, such as that from the four hydrocyclones, will be piped directly to the brine disposal well which also will be used for disposal of produced water. The pipes conveying liquid wastes to the disposal well will be kept in adequate repair and inspected regularly. Liquid waste which is not in proper form to be reinjected will be disposed of by evaporation in an excavated lined pit in conformance with Rule IX, "Avoidance of Fresh Water Pollution and Disposal of Salt Water or Other Liquids to Prevent Waste," of the State of Illinois Act in Relation to Oil, Gas, Coal and Other Surface and Underground Resources. Solid wastes which result from the filtering of river water or evaporation of waste liquids will be collected and disposed of by shipment to the properly classed landfill.

The same disposal options, with the additional possibility of removal by pump truck, exist for the polymer filtration and tank residue wastes. Liquid wastes of low viscosity will be piped to the reinjection well for disposal. Viscous wastes such as polymer residue will be collected by a hired waste tank truck. Samples of the waste will be analyzed bimonthly.

In the event of a chemical leak or spill around the project's surface facilities, the field manager will be immediately notified. Facilities are being built at the injection plant to handle such spills. A concrete-lined pit will be constructed at the polymer loading area. The cement loading area surface will be so constructed that all surfaces will drain into the pit. The pit will be equipped with a submersible pump so that any waste material collected can be pumped into disposal vessels and transported for proper disposal. This pit will also serve as an emergency sump for the injection plant. The plant area will have drains leading to the pit so any spilled material or water from backwashing filters can be collected and contained.

The two $8,860-\mathrm{gall}$ on oil storage tanks will be located inside a dike high enough to retain 19,400 gallons of leaked oil (two tanks' capacities, plus 10 percent). The bermed area will be graded to direct the flow into a containment area from which it will be pumped into a tank truck and 
shipped to a reprocessing plant or other suitable facility. In the event of a rupture, the oil will flow into an impermeable bermed or diked area. It will then be pumped out to a holding tank, and the area will be cleaned. Oil-absorbent material will be kept at the separation facility for routine cleanup and small spills; this supply of absorbent will be replaced as it is used.

\section{Inspection and Records}

The surface facility will be inspected in the last week of each operating month and the results recorded in the field operations log. Production facilities will have a flowline maintenance program to prevent spills from this source. The program will include monthly examinations of the production equipment and record keeping on all such activities.

Emergency telephone numbers as well as those of ERCO managers, the field manager, the waste tank truck removal service, and the local EPA inspector will be posted in several places in the injection facilities. Field personnel will be trained in the operation and maintenance of equipment and instructed in applicable pollution control regulations. 
$\bullet$

$-150-$ 
INSTRUMENTATION LIST

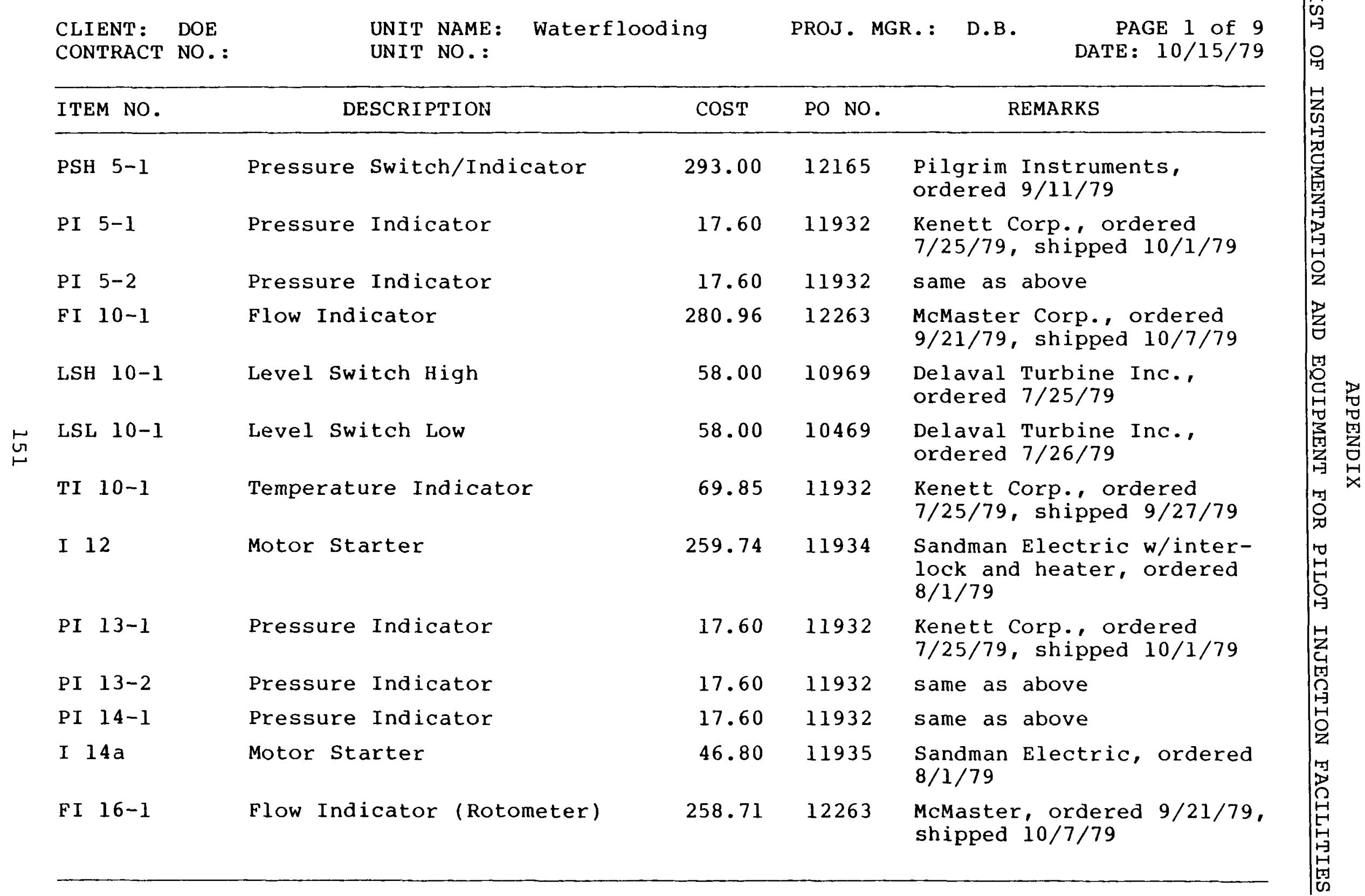




\section{INSTRUMENTATION LIST}

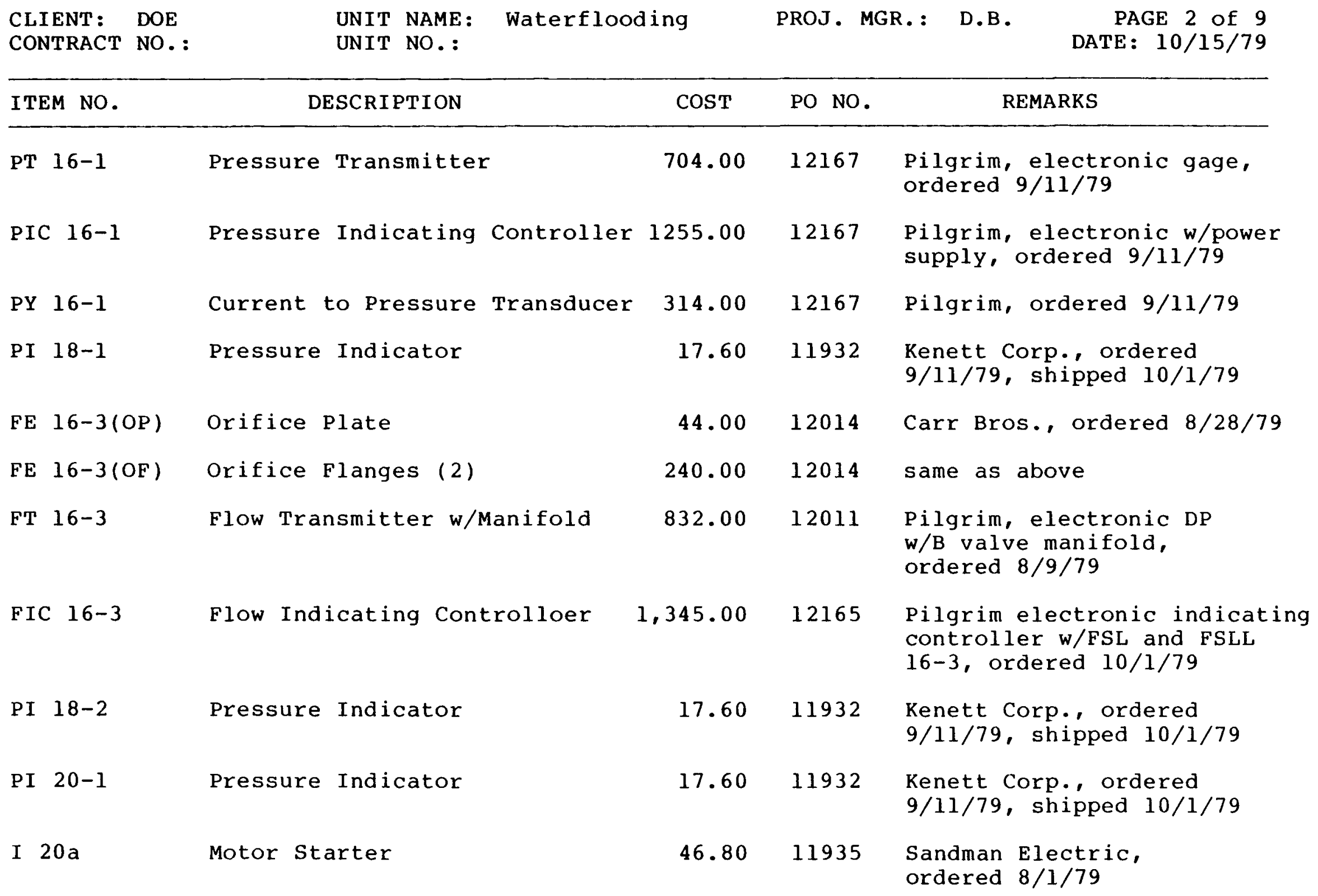




\section{INSTRUMENTATION LIST}

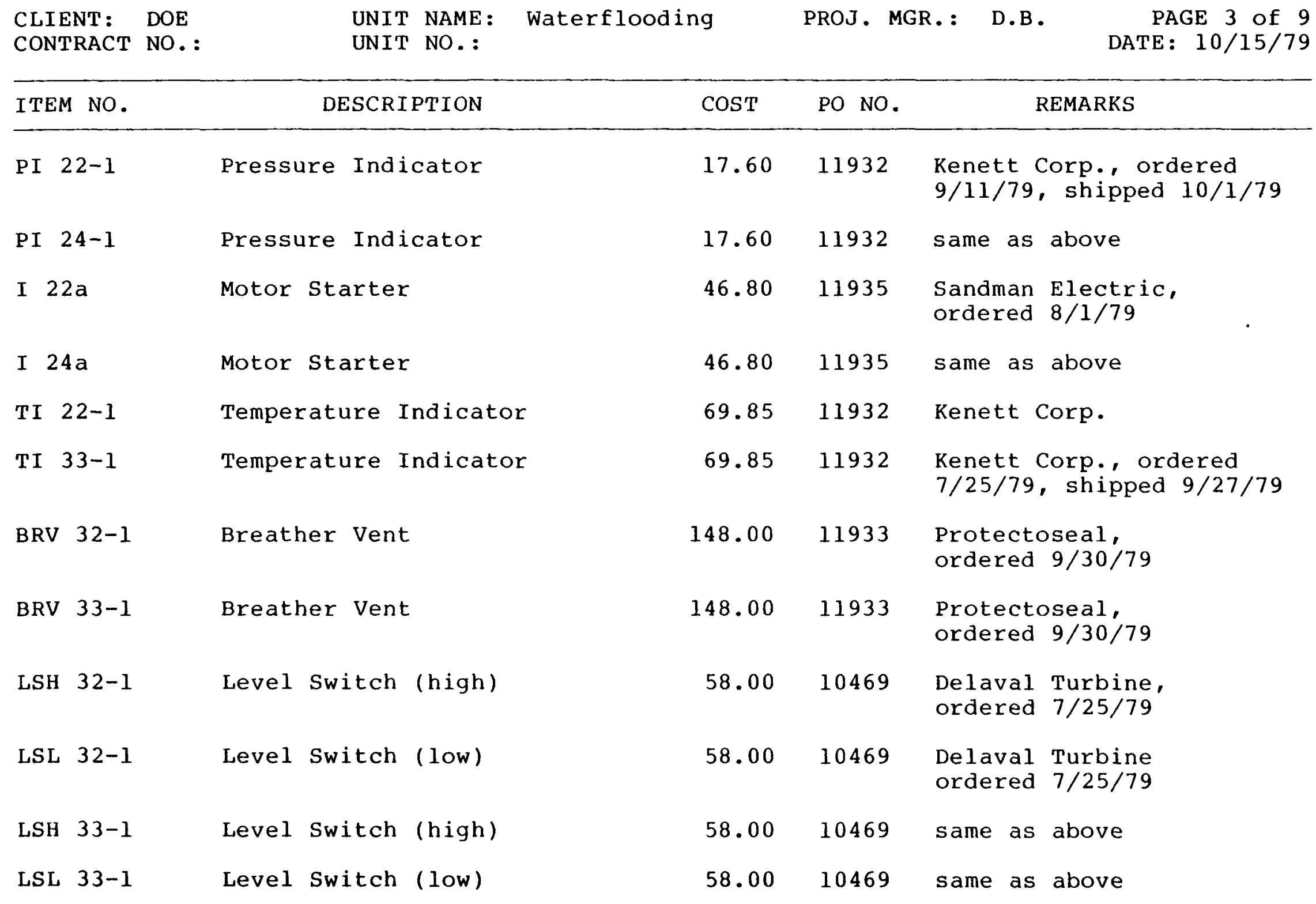




\section{INSTRUMENTATION LIST}

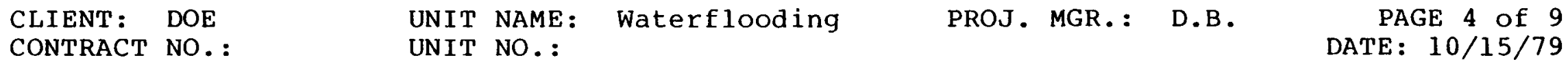

\begin{tabular}{|c|c|c|c|c|}
\hline ITEM NO. & DESCRIPTION & $\cos T$ & PO NO. & REMARKS \\
\hline PI 34-1 & Pressure Indicator & 17.60 & 11932 & $\begin{array}{l}\text { Kenett Corp. } \\
\text { ordered } 9 / 11 / 79 \\
\text { shipped } 10 / 1 / 79\end{array}$ \\
\hline I 36 & Motor starter & 163.02 & 11935 & $\begin{array}{l}\text { Sandman, } \\
\text { ordered } 8 / 1 / 79\end{array}$ \\
\hline FE $36-1(O P)$ & Orifice Plate & 42.00 & 12014 & $\begin{array}{l}\text { Carr Brothers, } 3 / 4 " \text { plate } \\
\text { w/bore calculation, } \\
\text { ordered } 8 / 28 / 79\end{array}$ \\
\hline $\mathrm{FE} 36-1$ (OF) & Orifice Flange & 131.00 & 12014 & $\begin{array}{l}\text { Carr Brothers, } 3 / 4 " \text { PVC } \\
15016 \text { flange, } \\
\text { ordered } 8 / 28 / 79\end{array}$ \\
\hline FI $36-1 \quad(M)$ & 3-Valve Manifold & 95.00 & 10214 & $\begin{array}{l}\text { Carr Brothers, SS manifold, } \\
\text { ordered } 8 / 28 / 79\end{array}$ \\
\hline FI $36-1$ & Flow Indicator & 345.00 & 10214 & $\begin{array}{l}\text { Carr Brothers, DPP Flow- } \\
\text { meter w/3" dial, ordered } \\
8 / 28 / 79\end{array}$ \\
\hline FE $40-1$ (OP) & Orifice Plate & 44.00 & 10214 & $\begin{array}{l}\text { Carr Brothers, } 21 / 2 \text { SS } \\
\text { plate } w / \text { bore calculation, } \\
\text { ordered } 8 / 28 / 79\end{array}$ \\
\hline FE $40-1$ (OF) & Orifice Flange (2) & 240.00 & 10214 & $\begin{array}{l}\text { Carr Brothers, } 21 / 2 " \text { PVC } \\
15016 \text { flange, ordered } \\
8 / 28 / 79\end{array}$ \\
\hline
\end{tabular}




\section{INSTRUMENTATION LIST}

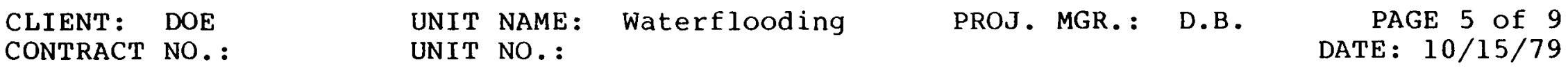

\begin{tabular}{llll}
\hline ITEM NO. DESCRIPTION & COST PO NO.
\end{tabular}

FI 40-1 (M) 3-Valve Manifold

FI 40-1

Flow Indicator

$95.00 \quad 10214$

Carr Brothers, ss manifold, ordered $8 / 28 / 79$

$345.00 \quad 10214$

Carr Brothers, DP flowmeter $w / 3 "$ dial, ordered $8 / 28 / 79$

ज

RIC $36-1$

Ratio Indicating Controller

RIC 36-1

FY $36-1$

Current-to-Pressure Transducer

314.00

12167

\author{
FY $40-1$ \\ LIC $40-1$
}

Current-to-Pressure Transducer

314.00

12167

Load Indicating Controller

$1,321.00$

12168

LE $\quad 40-1$

Level Element

819.00

12169

Pilgrim Instruments, electronic station $\mathrm{w} / \mathrm{cable}$ and resistor, ordered, 9/11/79

Pilgrim Instruments, transducer w/booster, ordered $9 / 11 / 79$

same as above

Pilgrim Instruments, electronic controller w/power supply, cable resister, ordered 9/11/79
Pierce Associates, level lance $w / c a b l e$ and probe, ordered $9 / 11 / 79$

LT $40-1$

TI 40-1
Temperature Indicator

69.85

11932

Kenett Corp. , ordered 7/25/79, shipped $9 / 25 / 79$ 


\section{INSTRUMENTATION LIST}

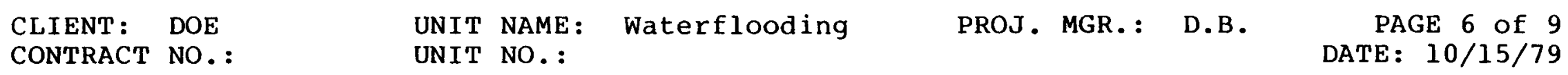

ITEM NO. DESCRIPTION COST PO NO. REMARKS

\begin{tabular}{|c|c|c|c|c|}
\hline BRV $40-1$ & Breather Vent & 148.00 & 11933 & $\begin{array}{l}\text { Protectoseal, } \\
\text { ordered } 9 / 30 / 79\end{array}$ \\
\hline LSH $\quad 40-1$ & Level Switch (high) & 58.00 & 10469 & Delaval, ordered $7 / 25 / 79$ \\
\hline LSL $40-1$ & Level Switch (low) & 58.00 & 10469 & same as above \\
\hline I 39 & Motor Starter & 163.02 & 11935 & Sandman, ordered $8 / 1 / 79$ \\
\hline PI 41-1 & Pressure Indicator & 17.60 & 11932 & $\begin{array}{l}\text { Kenett Corp.' } \\
\text { ordered } 9 / 11 / 79, \\
\text { shipped } 10 / 1 / 79\end{array}$ \\
\hline PI $41-2$ & Pressure Indicator & 17.60 & 11932 & same as above \\
\hline FI $44-1$ & Flow Indicator (Rotometer) & 251.06 & 12263 & $\begin{array}{l}\text { McMasters, ordered } 9 / 21 / 79 \text {, } \\
\text { due for shipment } 11 / 19 / 79\end{array}$ \\
\hline I 42 & Motor Starter & $2,150.46$ & 11934 & Sandman, ordered $9 / 11 / 79$ \\
\hline PY $42-1$ & Current to Pressure Transducer & 314.00 & 12167 & Pilgrim, ordered $9 / 11 / 79$ \\
\hline PIC 42-1 & $\begin{array}{l}\text { Pressure Indicating } \\
\text { Controller }\end{array}$ & $1,427.00$ & 12167 & $\begin{array}{l}\text { Pilgrim, electronic con- } \\
\text { troller w/pressure switch, } \\
\text { cable, resister, ordered } \\
9 / 11 / 79\end{array}$ \\
\hline $\mathrm{PCH} \quad 42-1$ & Pressure Switch (high) & & & \\
\hline
\end{tabular}




\section{INSTRUMENTATION LIST}

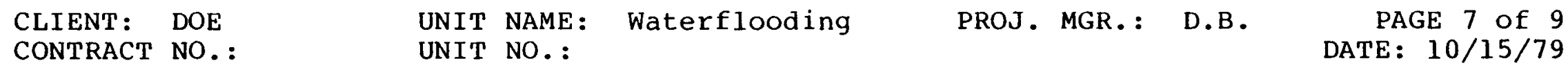

\begin{tabular}{|c|c|c|c|c|}
\hline ITEM NO. & DESCRIPTION & $\cos \mathrm{T}$ & PO NO. & REMARKS \\
\hline PT 50-1 & Pressure Transmitter & 774.00 & 12014 & $\begin{array}{l}\text { Carr Brothers, transmitter } \\
\text { w/power supply, ordered } \\
9 / 28 / 79\end{array}$ \\
\hline PRV 50-1 & Pressure Relief Valve & 845.00 & 12266 & $\begin{array}{l}\text { OCV, control valves, } \\
\text { ordered } 9 / 28 / 79\end{array}$ \\
\hline FR $50-1$ & Flow Recorder & $1,745.00$ & 12168 & $\begin{array}{l}\text { Pilgrim Instruments, multi } \\
\text { scan potentiometer record- } \\
\text { er, ordered } 9 / 11 / 79\end{array}$ \\
\hline FI $50-1$ & Flow Indicator & $5,590.00$ & 10372 & $\begin{array}{l}\text { Controlotron, display com- } \\
\text { puter w/multiplex switch }\end{array}$ \\
\hline FY 50 & Flow Transducer & $3,030.00$ & 10372 & $\begin{array}{l}\text { Controlotron, transducer } \\
\text { w/cable, ordered } 6 / 5 / 79\end{array}$ \\
\hline PR $50-1$ & Pressure Recorder & $1,185.00$ & $\begin{array}{l}12011 / \\
12012\end{array}$ & $\begin{array}{l}\text { Pilgrim Instrument, elec- } \\
\text { tronic recorder chart } \\
\text { w/resistor, mounting tray } \\
\text { and filter plates, ordered } \\
8 / 9 / 79\end{array}$ \\
\hline
\end{tabular}

PSL 50-1 Pressure Switch (low)

PR 50 tray Mounting Tray

$108.00 \quad 12165$ Pilgrim, slide mounting tray, ordered 9/11/79

I $5 \mathrm{a}$

Motor Starter

$259.74 \quad 12016$

Sandman, size 2 , ordered 9/7/79 


\section{INSTRUMENTATION LIST}

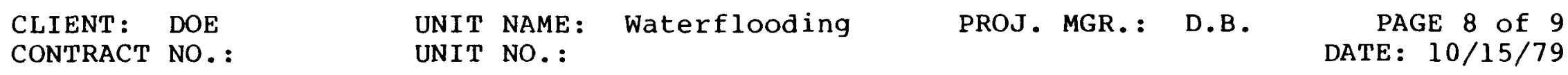

ITEM NO. DESCRIPTION COST PO NO. REMARKS

PRV 50-1 Pressure Relief Valve

FR 50-1

FI $50-1$

FY 50

PR 50-1

Pressure Recorder

Pressure Switch (low)

PSL $50-1$

PR 50 tray

I $5 \mathrm{a}$

Motor Starter

I $5 b$

Motor Starter

Mounting Tray

$\begin{array}{rl}845.00 & 12266 \\ 1,745.00 & 12168 \\ 5,590.00 & 10372 \\ 3,030.00 & 10372 \\ 1,185.00 & \begin{array}{l}12011 / \\ 12012\end{array}\end{array}$

OCV, control valves, ordered $9 / 28 / 79$

Pilgrim Instruments, multi scan potentiometer recorder, ordered $9 / 11 / 79$

Controlotron, display computer $\mathrm{w} / \mathrm{multiplex}$ switch

Controlotron, transducer $w / c a b l e$, ordered 6/5/79

Pilgrim Instrument, electronic recorder chart $w /$ resistor, mounting tray and filter plates, ordered $8 / 9 / 79$

$108.00 \quad 12165$

Pilgrim, slide mounting tray, ordered 9/11/79

259.74 12016 Sandman, size 2, ordered 9/7/79

$2,421.00 \quad 12016$

box, ordered 3/19/79, shipped $9 / 15 / 79$ 


\section{INSTRUMENTATION LIST}

$\begin{array}{llllrr}\text { CLIENT: } & \text { DOE } & \text { UNIT NAME: } & \text { Waterflooding } & \text { PROJ. MGR.: } & \text { D.B. } \\ \text { CONTRACT NO.: } & \text { UNIT NO.: } & & & \text { DATE: } 10 / 15 / 79\end{array}$

\begin{tabular}{llrrr}
\hline ITEM NO. & DESCRIPTION & COST & PO NO. & REMARKS \\
\hline I 39b & Motor Starter & 86.50 & 11934 & $\begin{array}{l}\text { Sandman, manual safety } \\
\text { starter, ordered } 8 / 1 / 79\end{array}$ \\
I 11 & Motor Starter & 197.34 & 11935 & $\begin{array}{l}\text { Sandman, magnetic starter, } \\
\text { ordered } 8 / 1 / 79, \\
10 / 1 / 79\end{array}$ on site
\end{tabular}

Total Estimated Cost

$33,049.95$ 


\section{EQUIPMENT LIST}

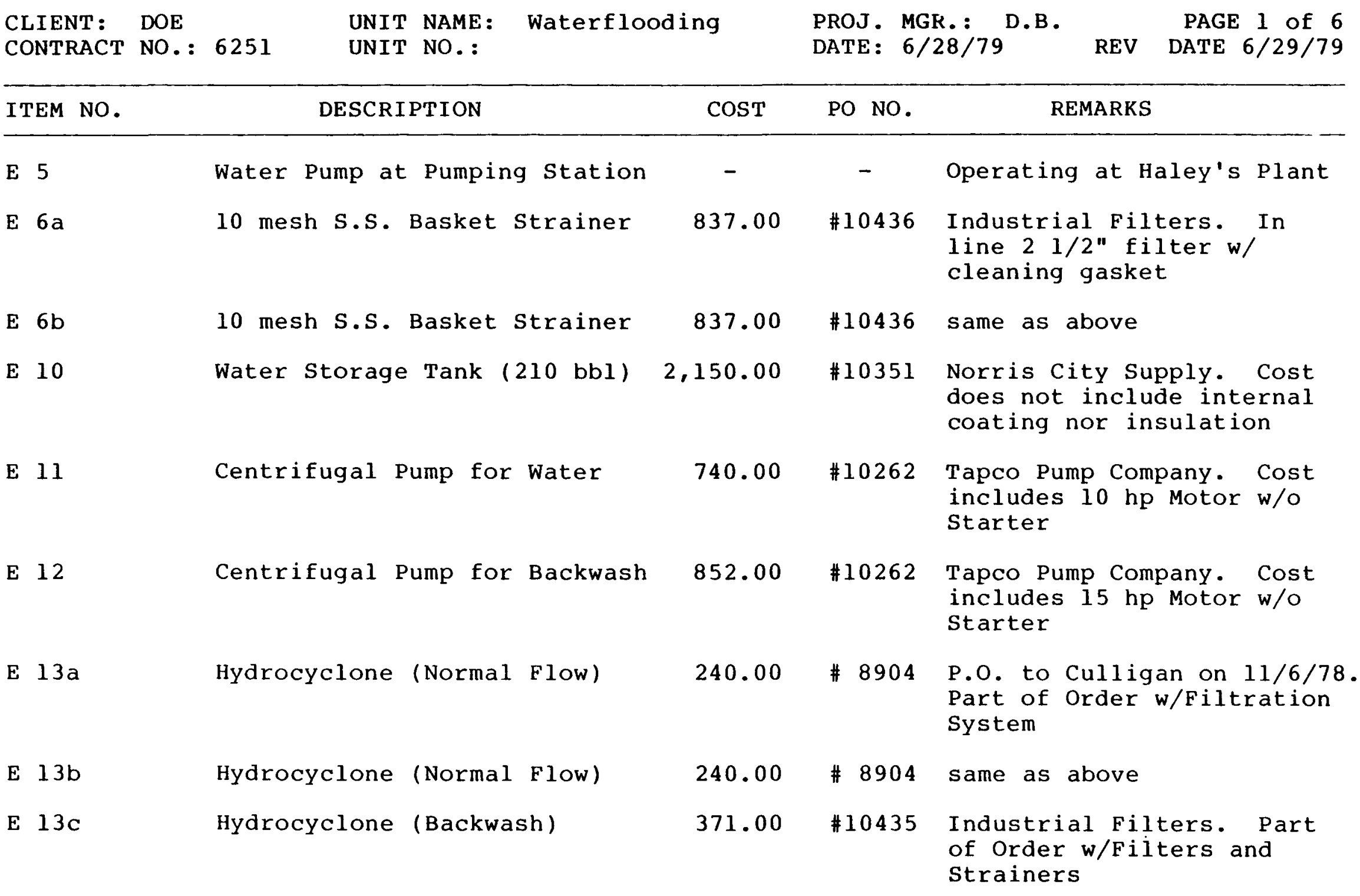


EQUI PMENT LIST

$\begin{array}{llllllr}\text { CLIENT: } & \text { DOE } & \text { UNIT NAME: } & \text { Waterflooding } & \text { PROJ. MGR.: } & \text { D.B. } & \text { PAGE } 2 \text { of } 6 \\ \text { CONTRACT } & \text { NO.: } 6251 & \text { UNIT NO.: } & & \text { DATE: } 6 / 28 / 79 & \text { REV }\end{array}$

ITEM NO. DESCRIPTION $\quad$ COST PO NO. REMARKS

E 13d Hydrocyclone (Backwash)

371.00 \#10435 Industrial Filters. Part of Order w/Filters and Strainers

Hydrocyclone (spare)

E 14

م
Coagulant Chemical System

None

Water Filtration System

Cartridge Filter

(w/16 extra cartridges)

None
Oxygen Scavenger system

240.00

E 20
499.00

$11,608.00$

606.00

$\# 10435$

$11,608.00$
606.00

$\# 10434$

P.O. Issued to Koch. Delivery expected August 1, 1979

(M14b) Tank, Liquid Level Switch (LI 14-1) + Agitator (m 14a)

Part of Order given to Culligan for water Filtration System.

P.O. to Indsutrial Filters $(6 / 18 / 79)$ Polypropylene type replaceable cartridges to remove particulates

499.00
\#10396
Acusan Co. Cost includes Pump (M 20 by Tank, Level Switch (LI 20-1) and Agitator 


\section{EQUI PMENT LIST}

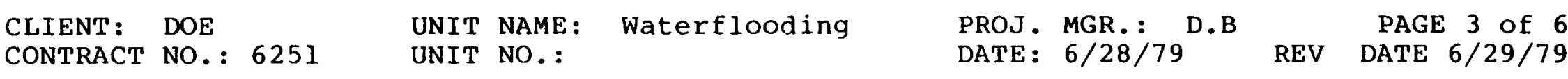

ITEM NO. DESCRIPTION COST PO NO. REMARKS

E 21 Static Mixer $378.00 \quad \# 10434$ Koch Industries. Delivery expected August 1, 1979

E 22

Chelating Agent System

499.00

\#10396 Acusan Co. Cost includes Pump (M 22b Tank, Level Switch (LI 2201) and Agitator

E 23

Oxygen Scavenger Sampler

$1,395.00$

Biocide Chemical System

Sampling Cylinder

Static Mixer

None

E 28
499

135.00

378.00

\#10373 Barclay Chemical Co. System includes Sensor and Analyzer

\#10396 Acusan Cost includes Pump (M 24b Tank, Level Switch (LI 24-1) and Agitator

\#10395 Joseph Bertram Company. Cost includes $150 \mathrm{ml}$ cylinder \& needle valve and ball valve

$\# 10434$ Koch Industries. Delivery expected August 1, 1979

135.00 \#10395 Bertram Company. Cost includes $150 \mathrm{ml}$ \& needle valve and toggle valve 


$\begin{array}{llllll}\text { CLIENT: } & \text { DOE } & \text { UNIT NAME: } & \text { Waterflooding } & \text { PROJ. MGR.: D.B. } & \text { PAGE } 4 \text { of } 6 \\ \text { CONTRACT NO.: } 6251 & \text { UNIT NO.: } & & \text { DATE: } 6 / 28 / 79 & \text { REV DATE } 6 / 29 / 79\end{array}$

ITEM NO. DESCRIPTION COST PO NO. REMARKS

E 29 none

E 30

E 31

$\stackrel{\leftarrow}{\omega}$

E 68

E 32

E 33

E 34

E 35

E 36
Plastic Basket Strainer

Rotary Valve Pump

Plastic Basket Strainer

Polymer Storage Tank

(210 bbl)

Polymer Storage Tank

Chemical Metering Pump

none

Dynamic Mixer
$(\$ 2,650.00)$

395.00

\#10466 Tapco. No order placed yet

Po to Industrial Filters. Polypropy in-line basket filters polymer from truck to storage tank

$\begin{array}{rr}395.00 & \# 10466 \\ 2,150.00 & \# 10351\end{array}$

Norris City Supply. Cost does not include internal coating or insulation

$2,150.00 \quad \# 10351$ same as above

2,282.00 \#10151 Robbins \& Myers. Meyno with variable special drive. Delivery expected Mid-August

4,170.00 \#10261 Greerco. Tandem Shear Mixer P.O. to Peter Kahn 6/31/79. Delivery expected August 1, 1979, inc. 2 HP motor 


\section{EQUIPMENT LIST}

\begin{tabular}{|c|c|c|c|c|c|c|}
\hline $\begin{array}{l}\text { CLIENT : } \\
\text { CONTRACT }\end{array}$ & $\begin{array}{l}\text { DOE } \\
\text { NO.: } 6251\end{array}$ & $\begin{array}{l}\text { UNIT NAME: } \\
\text { UNIT NO.: }\end{array}$ & Waterflooding & $\begin{array}{l}\text { PROJ : } \\
\text { DATE : }\end{array}$ & $\begin{array}{l}\text { MGR.: D.B. } \\
6 / 28 / 79\end{array}$ & $\begin{array}{c}\text { PAGE } 5 \text { of } 6 \\
\text { DATE } 6 / 29 / 79\end{array}$ \\
\hline
\end{tabular}

ITEM NO. DESCRIPTION COST PO NO. REMARKS

$\begin{array}{ll}\text { E } 37 & \text { none } \\ \text { E } 38 & \text { none }\end{array}$

E 39 Agitator

$2,753.00$

Final Dilution Tank (210 BBL.) 2,150.00

E 40

吕
S.S. Filter (100 mesh)

E $41 b$

E 42

E 43

E 44

E 45
S.S. Filter (100 mesh)

Triplex Plunger Pump

Sampling Cyclinder

Viscometer

Compressor
713

713

$$
4,000.00
$$

135.00

$3,072.00$

$(\$ 3,000.00)$

\section{$-$}

$-$

\#10436 Cleveland Mixer. Top mounted $\mathrm{w} / 1 \mathrm{l} 1 / 2 \mathrm{HP}$ to operate \& $45 \mathrm{M}$.

\#10351 Norris City Supply. Cost does not include Internal coating or insulation

\#10435 Industrial Filters. Replacement cloth cartridges. Remove particles down to $100 \mathrm{microns}$

$\# 10435$

\# 8864 Gardner Denver Triplex Pump PT $4 \mathrm{~L}$ w/o Motor

\#10395 $150 \mathrm{ml}$ cyclinder w/toggle valve and needle valve

\#10371 In-line $w /$ solenoid valve for operation control

To operate a 100 psi; 32 ACFM estimate from McMasters 


\section{EQUIPMENT LIST}

$\begin{array}{lllll}\text { CLIENT: } & \text { DOE } & \text { UNIT NAME: } & \text { Waterflooding } & \text { PROJ. MGR.: D.B. } \\ \text { CONTRACT NO.: } 6251 & \text { UNIT NO.: } & & \text { DATE: } 6 / 28 / 79 & \text { PAGE } 6 \text { of } 6 \\ \text { DATE } 6 / 29 / 79\end{array}$

ITEM NO. DESCRIPTION COST PO NO. REMARKS

$\begin{array}{ll}\text { E } 46 & \text { none } \\ \text { E } 47 & \text { none }\end{array}$

TOTAL ESTIMATED COST

$\$ 55,221.00$

宛 


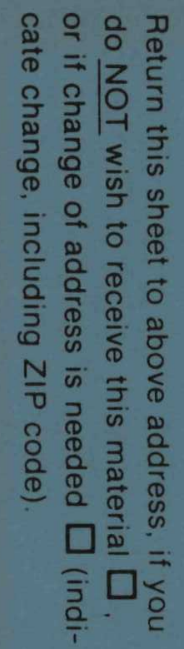

(

m. owc

品品=

걷미

$\pi \mathrm{m} \times \mathrm{m}$

足 $\dot{\omega} \leq=$

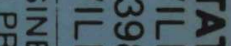

心 $m$ mm

m mo

ᄃ 즌

D ग

డ్టి

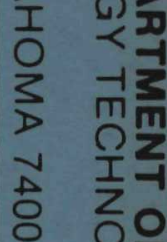

꾸

m

Q

กढ

ma

恧

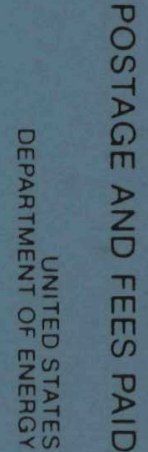

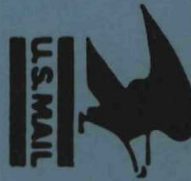

